\title{
ECOLOGICAL MONITORING AND COMPLIANCE PROGRAM 2006 REPORT
}

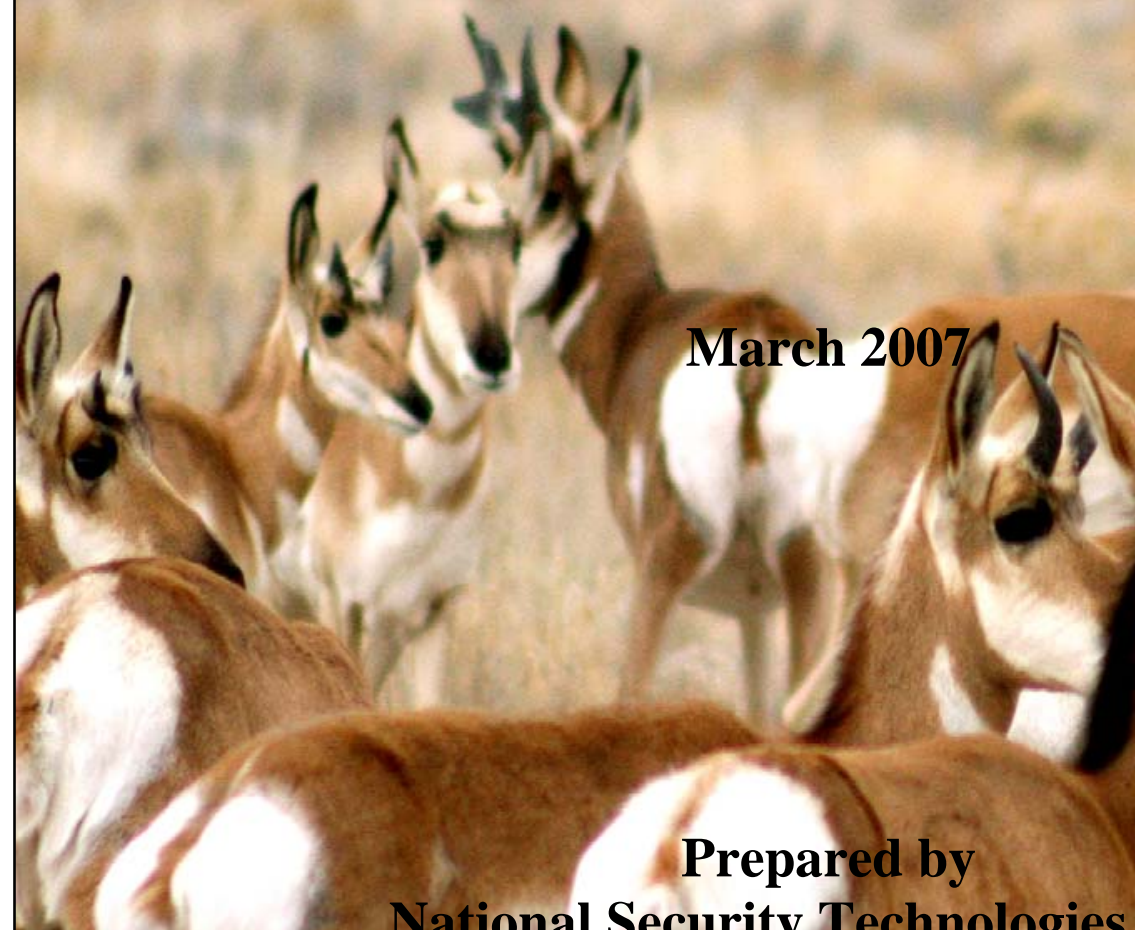

National Security Technologies, LLC Ecological Services P.O. Box 98521 Las Vegas, NV 89193-8521

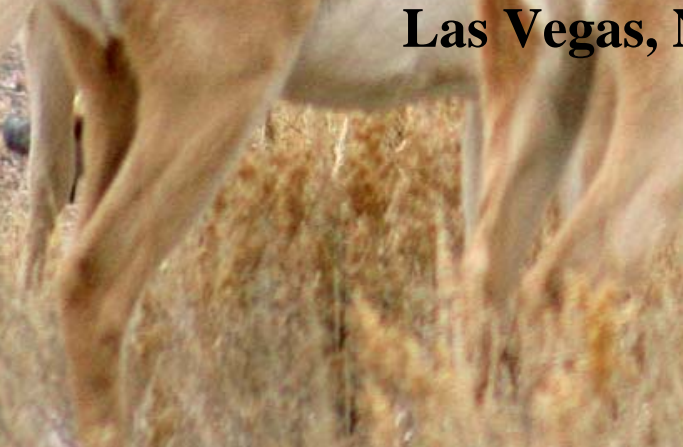




\section{DISCLAIMER}

Reference herein to any specific commercial product, process, or service by trade name, trademark, manufacturer, or otherwise, does not necessarily constitute or imply its endorsement, recommendation, or favoring by the United States Government or any agency thereof or its contractors or subcontractors.

\section{AVAILABILITY STATEMENT}

Available for sale to the public from-

U.S. Department of Commerce

National Technical Information Service

5285 Port Royal Road

Springfield, VA 22161-0002

Telephone: 800.553 .6847

Fax: 703.605.6900

E-mail: orders@ntis.gov

Online Ordering: http://www.ntis.gov/ordering.htm

Available electronically at http://www.osti.gov/bridge

Available for a processing fee to the U.S. Department of Energy and its contractors, in paper, from-

U.S. Department of Energy

Office of Scientific and Technical Information

P.O. Box 62

Oak Ridge, TN 37831-0062

Telephone: 865.576 .8401

Fax: 865.576.5728

E-Mail: reports@adonis.osti.gov

Front Cover Picture: A herd of pronghorn antelope (Antilocapra americana) on Frenchman Flat. (Photo by W. K. Ostler, January 2006) 


\title{
ECOLOGICAL MONITORING AND COMPLIANCE PROGRAM 2006 REPORT
}

\author{
March 2007 \\ WORK PERFORMED UNDER \\ CONTRACT NO. DE-AC52-06NA25946 \\ Prepared for the \\ U.S. Department of Energy \\ National Nuclear Security Administration \\ Nevada Site Office \\ Environment, Safety and Health Division \\ P.O. Box 98518 \\ Las Vegas, NV 89193-8518
}

Prepared by

National Security Technologies, LLC

Ecological Services

P.O. Box 98521

Las Vegas, NV 89193-8521 
THIS PAGE IS INTENTIONALLY LEFT BLANK 


\section{ABSTRACT}

The Ecological Monitoring and Compliance program (EMAC), funded through the U.S. Department of Energy, National Nuclear Security Administration Nevada Site Office (NNSA/NSO), monitors the ecosystem of the Nevada Test Site (NTS) and ensures compliance with laws and regulations pertaining to NTS biota. This report summarizes the program's activities conducted by National Security Technologies $^{\text {LLC }}$ (NSTec) during the Calendar Year 2006. Program activities included: (a) biological surveys at proposed construction sites, (b) desert tortoise compliance, (c) ecosystem mapping and data management, (d) sensitive plant species monitoring, (e) sensitive and protected/regulated animal monitoring, (f) habitat monitoring, (g) habitat restoration monitoring, and (h) monitoring of the Nonproliferation Test and Evaluation Complex (NPTEC).

Sensitive and protected/regulated species of the NTS include 44 plants, 1 mollusk, 2 reptiles, over 250 birds, and 26 mammals protected, managed, or considered sensitive as per state or federal regulations and natural resource agencies and organizations. The threatened desert tortoise (Gopherus agassizii) is the only species on the NTS protected under the Endangered Species Act. Biological surveys for the presence of sensitive and protected/regulated species and important biological resources on which they depend were conducted for 34 projects. A total of 342.1 hectares (ha) (845.37 acres [ac]) was surveyed for these projects.

Sensitive and protected/regulated species and important biological resources found included: 2 inactive tortoise burrows, 2 western burrowing owls (Athene cunicularia hypugaea), several horses (Equus caballus), 2 active predator burrows, mature Joshua trees (Yucca brevifolia), yuccas and cacti; and also 1 bird nest (2 eggs), 1 barn owl (Tyto alba) and 2 great-horned owls (Bubo virginianus). NSTec provided a written summary report of all survey findings and mitigation recommendations, where applicable. All flagged burrows were avoided during construction activities.

Twenty one of the 34 projects had sites within the distribution range of the threatened desert tortoise. NNSA/NSO must comply with the terms and conditions of a permit (called a Biological Opinion) from the U.S. Fish and Wildlife Service (FWS) when conducting work in tortoise habitat. No tortoises were

found in or displaced from project areas. No desert tortoises were accidentally injured or killed, nor were any captured or displaced from project sites. One desert tortoise was accidentally killed along a paved road. One site specific revegetation plan was submitted this year as required by the desert tortoise habitat revegetation plan approved in 2004. This year a total of 1.89 ha $(4.69 \mathrm{ac})$ of tortoise habitat was disturbed. Revegetation of habitat at the Bren Tower burn was completed in the spring of 2006.

In the summer of 2006, NSTec scientists prepared a Biological Assessment of the security activities that were being conducted at the Device Assembly Facility (DAF). NNSA requested a Biological Opinion from FWS in late 2006.

Ecosystem mapping and data management in 2006 focused primarily on two tasks: (a) converting hardcopies of about 17 reports (EMAC annual reports and selected topical reports from 1996 to 2003) into electronic versions (Portable Document Format [PDF] files) to facilitate electronic document exchange, rapid retrieval, duplication, and printing, and (b) conducting an annual vegetation survey to determine wildland fire hazards on the NTS. Copies of the PDF documents were sent to DOE's Office of Scientific and Technical Information website in Oak Ridge, Tennessee, and the DOE National Nuclear Security Administration Nevada Site Office (NNSA/NSO) Public Reading Facility. 
There has been an average of 11 wildland fires per year on the NTS since 1978 with an average of about 96 hectares (ha) (23 acres [ac]) per fire. In 2006 there were 16 wildland fires and a total of 3,486 ha (8,615 ac) burned; the largest was located in Mid Valley (about 3,270 ha [8,000 ac]). These wildland fires do not occur randomly across the NTS but occur more often in blackbrush vegetation types that have sufficient fuels (fine-textured and woody fuels) that are conducive to ignition and spread of wildland fires. Based on the dates and number of fires on the NTS occurring historically, a fire season was identified as occurring during the months of June through August. Precipitation in 2006 was about 20 percent above average for the winter months which contributed to a slight increase in fine fuels, however, a substantial amount of fine fuels from 2005 still persisted. A road survey to evaluate wildland fire fuel hazards was conducted and maps showing indices for fine fuels, woody fuels, and combined fuels is presented in this report. A combined fuels index for the NTS in 2006 was calculated at 5.26, compared to 5.64 and 4.88 in 2005 and 2004, respectively. A map is presented showing the historical location of wildland fires on the NTS for 2006, 2005, and prior years. A peer-reviewed publication describing wildland fires on the NTS was submitted and accepted for publication.

Populations of Frasera pahutensis (Pahute green gentian) and Hulsea vestita ssp. inyoensis (Pumice alpinegold) were inventoried and detailed delineations of the population boundaries were made. There appears to be an abundance of potential habitat for these species on the NTS and additional locations may be found in the future as more remote locations are accessed and surveyed. One new population of Ivesia arizonica var. saxosa (Rock purpusia) was found about 2,000 meters (m) $(6,561 \mathrm{feet}[\mathrm{ft}])$ south of Columbine Canyon and covers almost 10 hectares (ha) (25 acres [ac]) on westerly and northerly exposed boulders of Rainier Mesa tuff. Plants at this location are more abundant than at the Columbine Canyon population. A bryophyte collection made in 2005 and 2006 in the Rock Valley area was positively identified as Entosthodon planoconvexus and is now included on the list of sensitive plant species on the NTS. The Mercury Ridge population of Eriogonum heermannii var. clokeyi (Clokey buckwheat) was monitored this year with the objective of making voucher collections, but because of poor growing conditions no collections were made. The taxonomy of Cymopterus ripleyi var. saniculoides and $F$. pahutensis was confirmed at this year's Rare Plant Workshop. Penstemon fruticiformis var. amargosae (Death Valley beardtongue) which may occur along the southern boundary of the NTS and Phacelia filiae (Clarke phacelia), a newly described species, were added to the list of sensitive plants species for the NTS. Sclerocactus polyancistrus (redspined fishhook cactus), a cactus widespread throughout several western states, was removed from the list of sensitive plant species for the NTS. There are currently 20 species on the list of sensitive plant species for the NTS.

Surveys for the western red-tailed skink (Eumeces gilberti rubricaudatus), a sensitive species, were conducted this year. A total of 9 skinks were captured in 6,092 trap days $(0.1$ percent, 1 skink/677 trap days). To our knowledge, this is a new Nevada record for the most skinks caught in a study. Skinks were captured at 7 of 48 locations, including 6 new locations. All skinks were captured in funnel traps set near rocks or vegetation. No skinks were caught in trap arrays, which indicates that drift fences are not necessary to capture skinks. This significantly reduces the amount of effort and cost required to trap skinks. Additionally, over 500 other reptiles were captured or observed, representing 10 of 16 known lizards and 11 of 17 known snakes on the NTS. Overall trap success was 8.8 percent (538 captures/6,092 trap days).

Western burrowing owl monitoring entailed trapping owls as part of a collaborative effort with Dr. Courtney Conway who is funded by the Department of Defense Legacy Project to evaluate migratory linkages of owls in western North America and document new owl locations. A total of 34 owls, including 16 adults and 18 juveniles, were captured. One adult female owl that was banded last year as a juvenile was captured again this year, $5.3 \mathrm{~km}$ from her natal site. Radioisotopic analysis of the feathers from this owl should provide information on where she spent the winter. Additionally, six new burrow 
sites were found, including four burrows in the Mojave Desert ecoregion and two in the Great Basin Desert ecoregion. This makes a total of 132 known western burrowing owl locations (30 owl sightings and 102 burrow sites) on the NTS.

In 2006 small mammal trapping was conducted to assess the distribution of kangaroo mice (Microdipodops spp.) and to investigate habitat use of other small mammal species. A total of 2,965 animal captures were recorded in 7,488 trap nights at 23 sites. No kangaroo mice were captured, however, 14 other species were captured. Small mammal trapping at 10 paired sites on the NTS that compared wash habitat to upland habitat showed significant differences in proportions of nocturnal species trapped at all but one site. These differences generally inferred some species' preferences for rocky habitats as opposed to non-rocky habitats. At Trail Ridge, comparing trapping results from 1981-83 to data from 2006 indicated a large increase in the abundance of Merriam's kangaroo rat (Dipodomys merriami) when it was previously rare.

Bat monitoring focused on sampling known maternity roosts to determine occupancy patterns and compare techniques for counting bats; conducting pre-closure surveys at $\mathrm{N}$ and $\mathrm{T}$ Tunnel Complexes to determine if gating is necessary; passive acoustic monitoring of bat activity at Camp 17 Pond; and responding to numerous calls to remove bats, including a rabid bat, and documenting their roost sites. Maternity roosts occupied in previous years were occupied again this year by both Townsend's big-eared bat (Corynorhinus townsendii) and fringed myotis (Myotis thysanodes). Counts from the two types of cameras showed varying results. Counting bats was easier using the images from the NightSight ${ }^{\mathrm{TM}}$ camera than images from the Sony® nightshot camera. Two bat gates were installed in the N Tunnel Complex. These are the first bat gates to be installed on the NTS. Several thousand files containing bat vocalizations were recorded from Camp 17 Pond and are in the process of being analyzed. The first rabid bat on the NTS was collected and 23 bats in or around buildings were found roosting (8 dead) on 19 occasions at 15 buildings (9 in Mercury, 5 in Area 6, and one in Area 27). Ten bats were western pipistrelles (Pipistrellus hesperus), five were pallid bats (Antrozous pallidus), one was either California or small-footed myotis (Myotis spp.), and seven were unknown species.

The total number of horses on the NTS has increased from a low of about 31 in 1999 to about 53 individuals in 2006. Moderate numbers of young horses have been recruited to the population during this period. Mountain lion predation pressure may be reduced on horses allowing the increase, because many more deer are now available as prey.

Deer counts have increased greatly in number per session from lows of 4-42 in 2002 to highs of 153-245 in 2006. This represents about a 5-6 fold increase in total numbers of deer counted and much higher numbers counted in the Rainier Mesa area.

Mountain lions (Puma concolor) prey on wild horses, deer, antelope, and tortoises, and pose a potential threat to humans on the NTS. In order to help evaluate the extent of risks to such animals a collaborative effort between Erin Boydston, a research scientist with USGS, and NSTec biologists to investigate mountain lion distribution and abundance was continued again this year using remote, motion-activated cameras. Cameras were set up at 12 sites where mountain lions were likely to occur. Only one mountain lion was photographed, a female at Tub Spring in late March. At least 29 other species of mammals and birds were also detected with the greatest activity at water sources, particularly during the dry summer and fall months.

West Nile Virus (WNV) is a potentially serious illness that is spread to humans and other animals through mosquito bites. WNV surveillance continued during 2006 for the third consecutive year to determine if 
mosquitoes on the NTS carry WNV. Eight sites were sampled during 14 surveys. Mosquitoes were taken to Clark County Health District personnel for species identification and WNV testing. A total of 111 individuals representing 6 species were captured and analyzed. All specimens tested for WNV were negative except for one Culiseta inornata from Well 3 Pond which was suspect. Therefore, it may be possible that WNV is present in at least one mosquito species on the NTS but it is yet to be confirmed. This site will be sampled more intensively along with other sites next year to try and confirm if WNV is present on the NTS. This year, three new species of mosquito were detected. Additionally, six injured raptors were taken to the North Las Vegas Animal Hospital for treatment and WNV testing. All raptors tested negative for WNV.

The habitat restoration monitoring program on the NTS periodically monitors research sites, project sites, cover caps and areas burned by wildland fires that have been revegetated. The objective of evaluating these sites is to analyze the long-term effects of certain reclamation techniques or other factors on plant establishment and survival. From this information revegetation procedures and techniques may be revised and the potential for revegetation success enhanced. Staging areas at four sites and closure cover caps at four sites were monitored in 2006. Sites ranged in size from $0.2 \mathrm{ha}(0.6 \mathrm{ac})$ to over $4 \mathrm{ha}(10 \mathrm{ac})$. All four staging areas monitored this year were on the Tonopah Test Range (TTR). Plant cover values for all four sites were higher on the revegetated area than on adjacent reference areas. Plant density was also higher or equal to that estimated for the respective reference areas. Two of the four cover caps were also located on the TTR. Plant cover on the cover caps at the Cactus Springs waste trench site and the Rollercoaster Sewage Lagoon was higher than recorded for the corresponding reference areas. Cover at the Cactus Springs site was the highest plant cover recorded since revegetation began. Plant density values were mixed. At the Cactus Springs site, density was lower than on the reference area, while at the Rollercoaster site plant density was higher. On the Central Nevada Test Area (CNTA) cover cap, plant cover was the second highest ever recorded, however, it is still slightly below cover estimates on the adjacent reference area. Plant density at CNTA is almost double what it is on the reference area. On the NTS in Area 3 the amount of cover on the U-3ax/bl cover cap was the highest ever estimated for this site although plant density has declined the last few years. Overall, the vegetation on the project sites is becoming well established. Shrubs and grasses are vigorous and healthy. Plant cover and density are similar to that on adjacent reference areas.

Chemical release test plans for two activities, Raven and Tarantula II, at the Non-Proliferation Test and Evaluation Complex (NPTEC, formerly the Hazardous Materials Spill Center) on Frenchman Lake playa were reviewed. Because chemical releases were such low volumes or low toxicity there was no need to monitor downwind transects for biological impacts. Seasonal sampling of downwind and upwind transects near the NPTEC was conducted to document baseline conditions of biota. No differences in biota were noted along downwind (treatment) versus upwind (control) transects. 


\section{CONTENTS}

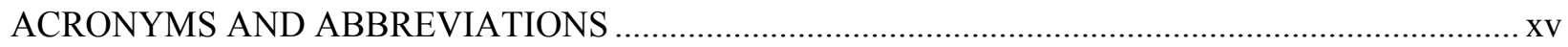

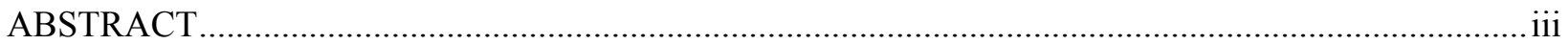

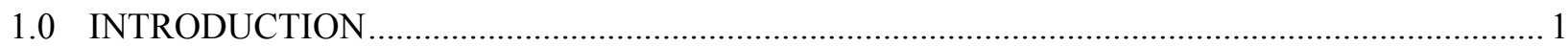

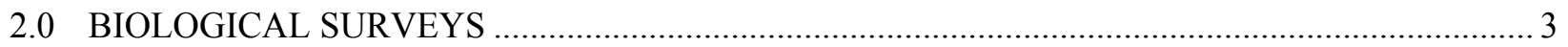

2.1 Sites Surveyed and Sensitive and Protected/Regulated Species Observed .............................. 3

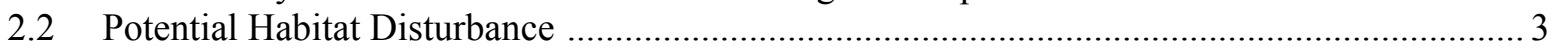

2.3 Coordination with Biologists and Wildlife Agencies ....................................................... 14

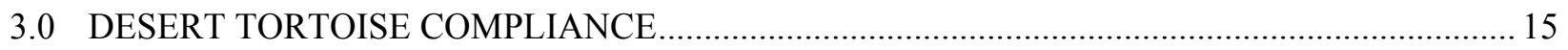

3.1 Project Surveys and Compliance Documentation ........................................................... 15

3.2 Habitat Revegetation Plan for Loss of Tortoise Habitat .................................................... 18

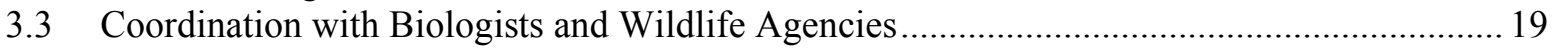

3.4 Biological Assessment for Chemical Testing at Port Gaston ............................................... 19

3.5 Biological Opinion for Security Activities at DAF ........................................................ 19

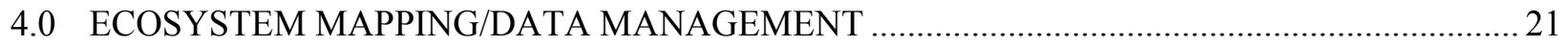

4.1 Conversion of Older EMAC and Selected Topical Reports to PDF files .............................. 21

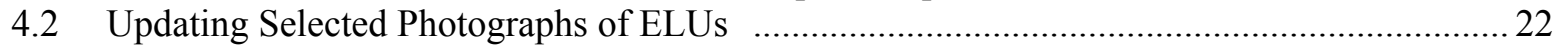

4.3 Vegetation Survey for Determining Wildland Fire Hazards …........................................... 22

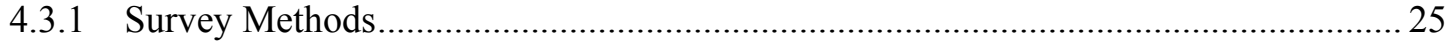

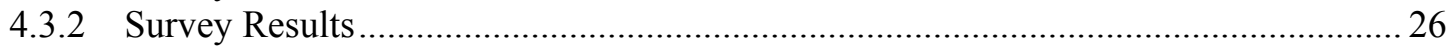

4.4 Coordination with Scientists and Ecosystem Management Agencies .................................. 37

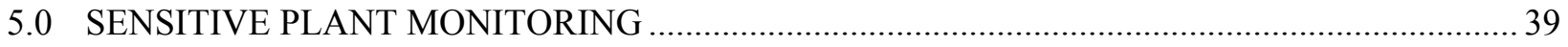

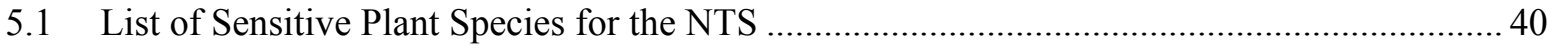

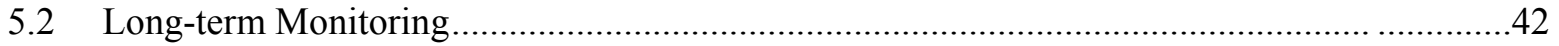

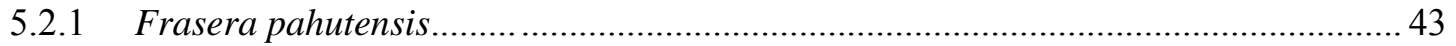

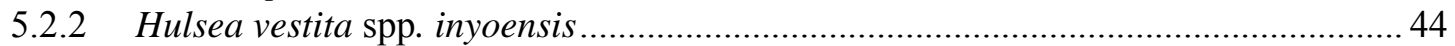

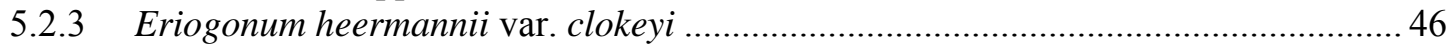

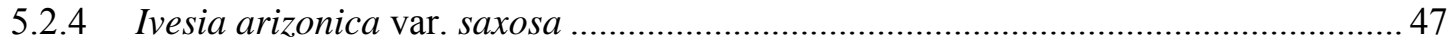

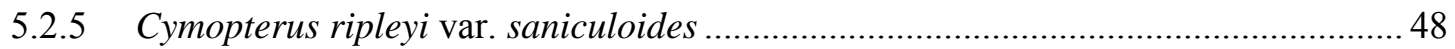

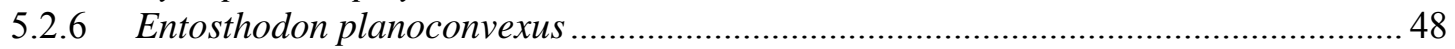

6.0 SENSITIVE AND PROTECTED/REGULATED ANIMAL MONITORING …........................... 49

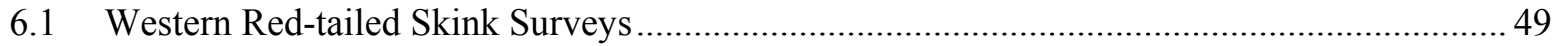

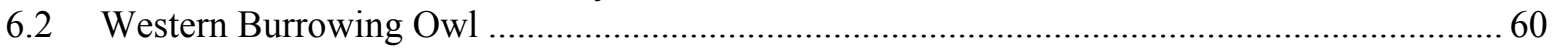

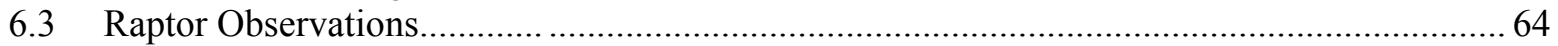

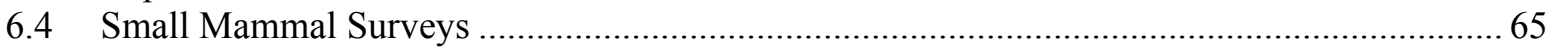

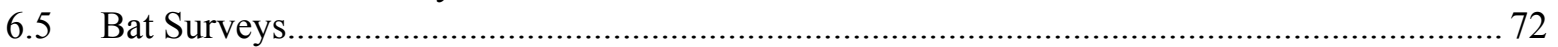

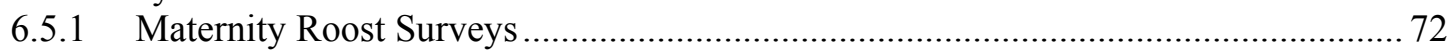

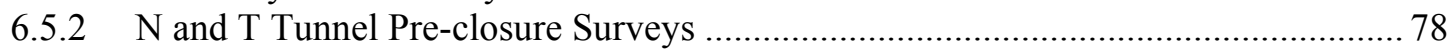




\section{CONTENTS (Cont'd)}

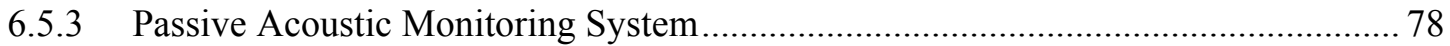

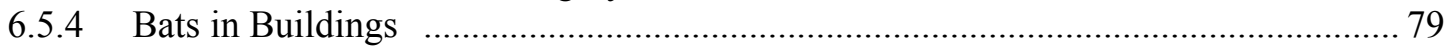

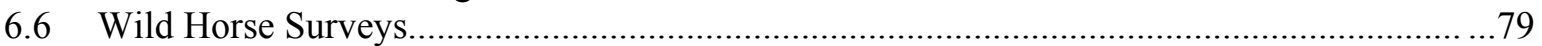

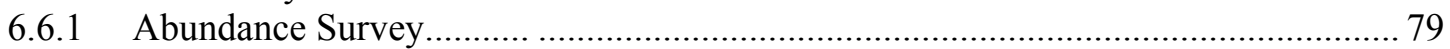

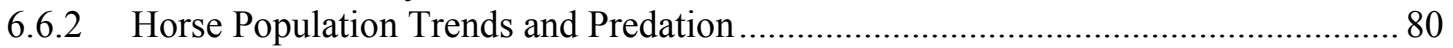

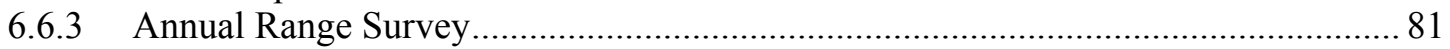

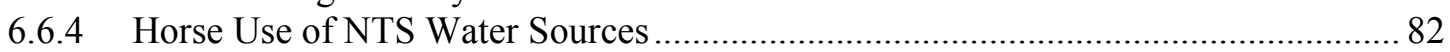

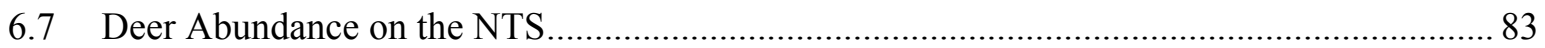

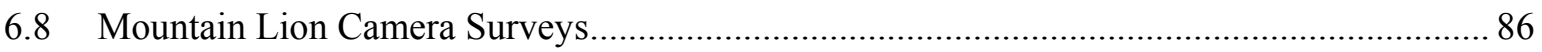

6.9 Coordination with Biologists and Wildlife Agencies.................................................... 88

7.0 HABITAT MONITORING

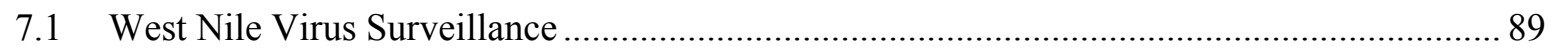

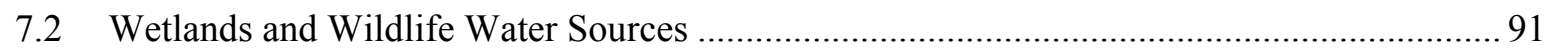

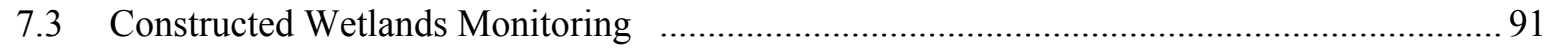

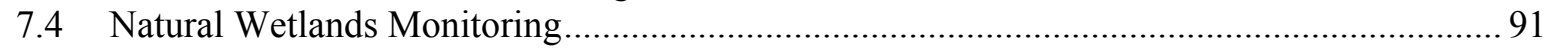

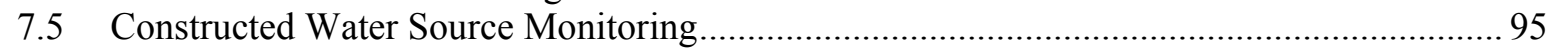

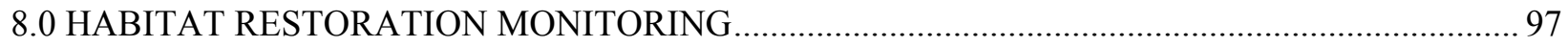

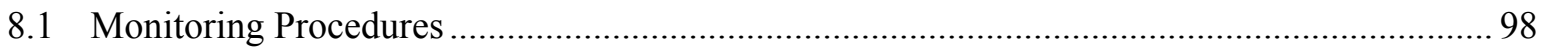

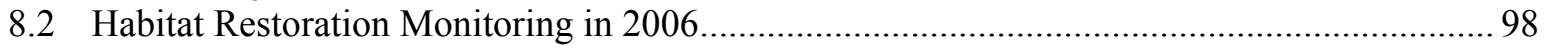

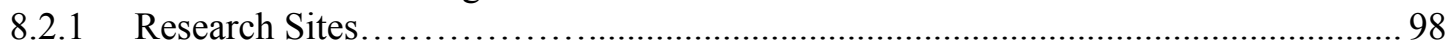

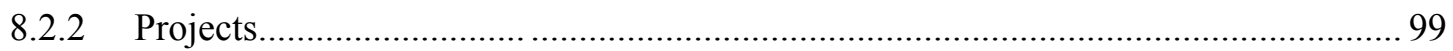

8.2.2.1 CAU 400-Five Points Landfill ................................................................ 99

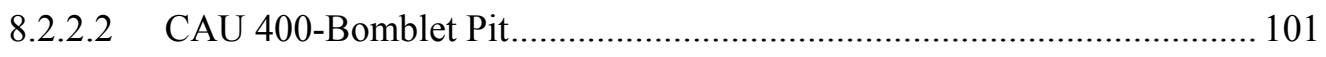

8.2.2.3 CAU 426-Cactus Springs Waste Trenches ............................................... 103

8.2.2.4 CAU 404-Rollercoaster Sewage Lagoons ............................................... 105

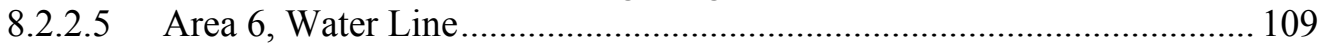

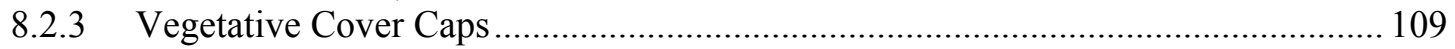

8.2.3.1 CAU 417-Central Nevada Test Area: Cover Cap ................................... 109

8.2.3.2 CAU 426-Cactus Springs Waste Trenches: Cover Cap ........................... 113

8.2.3.3 CAU 404-Rollercoaster Sewage Lagoons: Cover Cap ............................ 114

8.2.3.4 CAU 110-Area U-3ax/bl: Closure Cap ................................................ 116

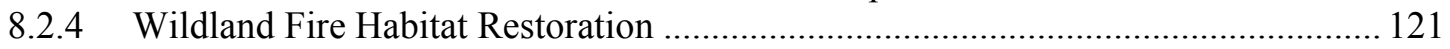

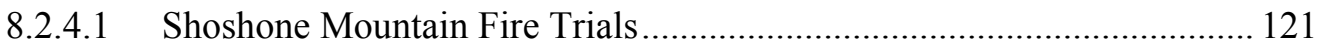

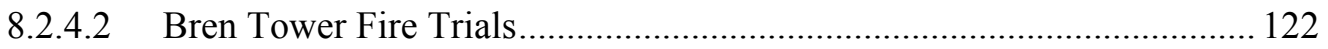

9.0 MONITORING OF THE NON-PROLIFERATION TEST AND EVALUATION COMPLEX .... 123

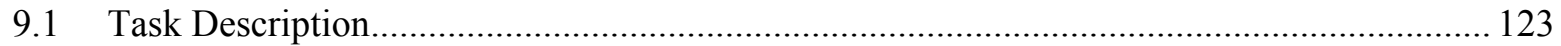

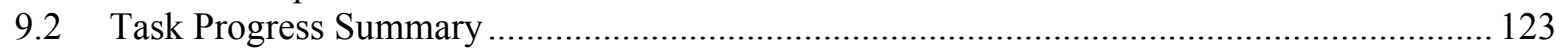

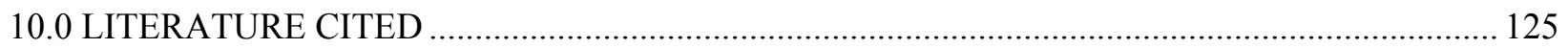

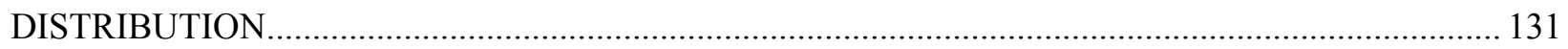




\section{LIST OF FIGURES}

Figure 2-1. Biological surveys conducted on the NTS during 2006............................................ 8

Figure 2-2. Biological surveys conducted in important habitats of the NTS during 2006 ................... 13

Figure 3-1. Biological surveys conducted in desert tortoise habitat on the NTS during 2006 .............. 17

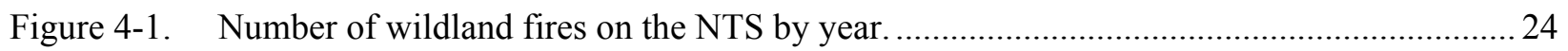

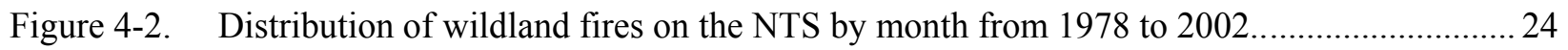

Figure 4-3. Extended weather forecast for June, July, and August of 2006 for temperature

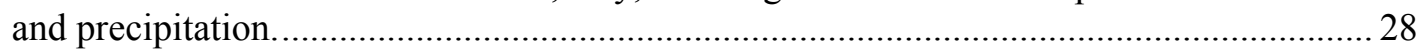

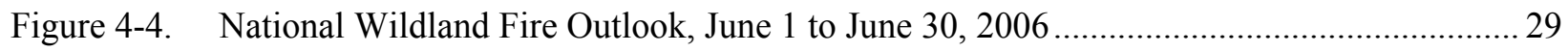

Figure 4-5. Index of fine fuels for 211 survey stations on the NTS by operational area

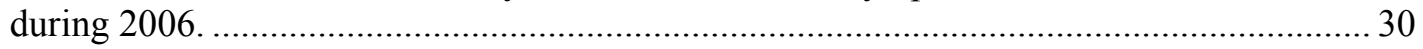

Figure 4-6. Index of woody fuels for 211 survey stations on the NTS by operational area during 2006.

Figure 4-7. Index of combined fine fuels and woody fuels for 211 survey stations on the NTS by operational area during 2006

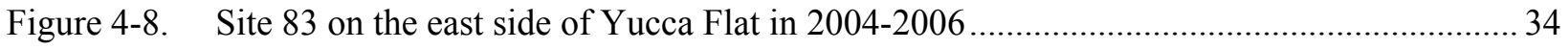

Figure 4-9. Site 99 on the east side of Yucca Flat in 2004-2006 ....................................................... 35

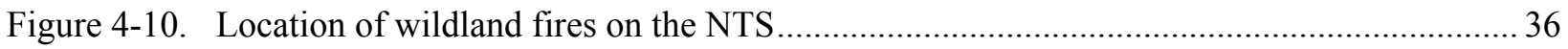

Figure 5-1. Known locations of Frasera pahutensis, Ivesia arizonica var. saxosa and Hulsea vestita spp. inyoensis on the NTS 43

Figure 5-2. Typical habitat for F. pahutensis in transition between pinyon woodland and sagebrush shrubland on Pahute Mesa 45

Figure 5-3. Typical habitat for F. pahutensis in pinyon woodland along abandoned trails................... 45

Figure 5-4. H. vestita spp. inyoensis along road cut on Holmes Road, Rainier Mesa ........................... 46

Figure 5-5. I. arizonica var. saxosa growing on north and west faces of large boulders on Pahute Mesa 


\section{LIST OF FIGURES (Cont'd)}

Figure 6-1. Western red-tailed skink (Eumeces gilberti rubricaudatus) captured at Twin Spring, Site \#9.

Figure 6-2. Western red-tailed skink distribution on the NTS including historic locations and sites sampled for skinks during 2006

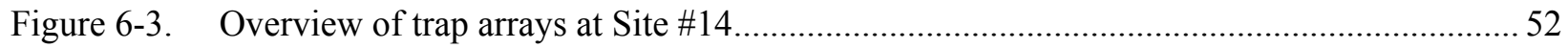

Figure 6-4. Funnel trap where a skink was captured, set near rocks at Site \#34 ................................ 52

Figure 6-5. Western red-tailed skink (Eumeces gilberti rubricaudatus) captured

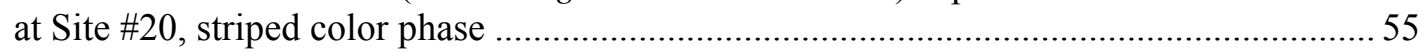

Figure 6-6. Desert banded gecko (Coleonyx variegates) captured at Site \#15 .................................... 56

Figure 6-7. Ring-necked snake (Diadophis punctatus) captured at Site \#34...................................... 56

Figure 6-8. Night snake (Hypsiglena torquata) caught under a rock at Site \#20 ................................ 57

Figure 6-9. Western long-nosed snake (Rhinocheilus lechontei) captured at Site \#20 ........................57

Figure 6-10. Mohave patch-nosed snake (Salvadora hexalepis) captured at Site \#4 .............................58

Figure 6-11. California kingsnake (Lampropeltis getula) in funnel trap at Site \#2 ...............................58

Figure 6-12. $\quad$ Long-tailed weasel (Mustela frenata) captured at Site \#19 ..............................................59

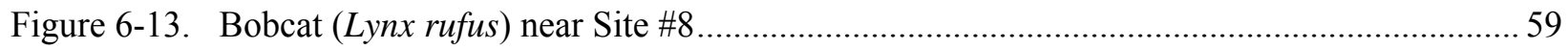

Figure 6-14. Known western burrowing owl distribution on the NTS and burrow sites where trapping occurred

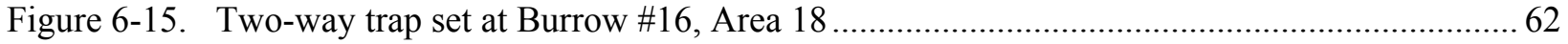

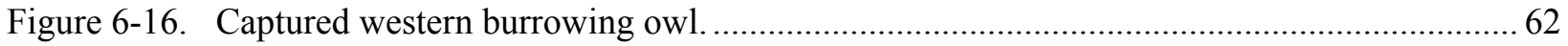

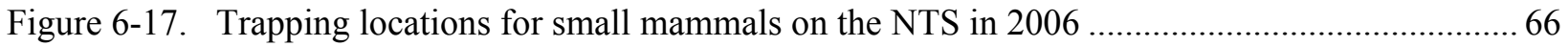

Figure 6-18. View of Tippipah Spring showing narrowness of habitat sampled for mammals and reptiles

Figure 6-19. Western harvest mouse captured at Whiterock Spring showing long tail.

Figure 6-20. Great Basin pocket mouse at PAM001 plot in Area 20 showing silky pelage .70 


\section{LIST OF FIGURES (Cont'd)}

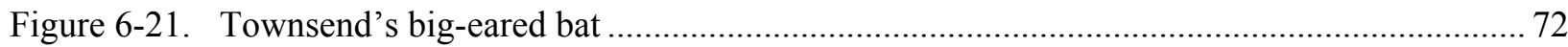

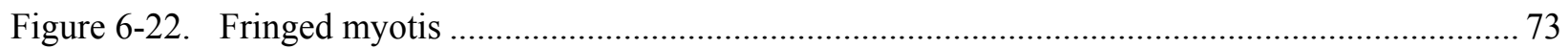

Figure 6-23. Sites monitored for bat activity during 2006 including adits sampled for maternity colony population trends, tunnels sampled for bat use before closure, and buildings where nuisance bats were removed.

Figure 6-24. Passive acoustic monitoring system at Camp 17 Pond.................................................... 78

Figure 6-25. Trends in the age structure of the horse population from 1999 to 2006 ............................ 81

Figure 6-26. Feral horse sightings and horse sign observed on the NTS during 2006 .........................8 82

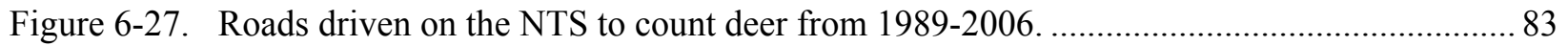

Figure 6-28. Image of two male mule deer spotlighted on the Rainer Mesa Route .............................. 84

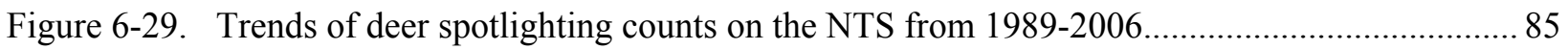

Figure 6-30. Mountain lion (Puma concolor) photographed at Tub Spring ........................................ 88

Figure 7-1. Mosquito trap set at Well 5B in Frenchman Flat .......................................................... 90

Figure 7-2. Natural water sources on the NTS, including those monitored during 2006 .................... 92

Figure 7-3. Constructed water sources monitored for wildlife use and mortality on the NTS during 2006 96

Figure 8-1. Vegetation on staging area at the Rollercoaster Sewage Lagoon closure site in 2000 and 2005 108

Figure 8-2. CNTA closure cover cap in 2000 following site preparation and seeding (top photograph) and June 2006 (bottom photograph)

Figure 8-3. CAU 110, U-3ax/bl closure cover cap one year after revegetation in the spring of 2001 (top) and the spring of 2006 (bottom). 


\section{LIST OF TABLES}

Table 2-1. List of sensitive and protected/regulated species known to occur on or adjacent to the NTS

Table 2-2. Summary of biological surveys conducted on the NTS during 2006............................ 9

Table 2-3. Total area in hectares (ac) proposed for disturbance within important habitats in 2006 and over the past eight fiscal years

Table 3-1. Summary of tortoise compliance activities conducted by NSTec biologists ...................... 16

Table 3-2. Parameters and threshold values for desert tortoise monitoring on the NTS ...................... 18

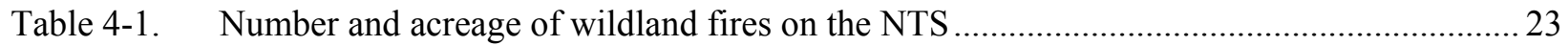

Table 4-2. Precipitation history and percent presence in surveyed sites (top species contributing to fine fuels)

Table 4-3. Inches of precipitation for meteorological recording stations on the NTS for January through April 2006 compared to long-term averages

Table 4-4. Comparison of fuels rating for NTS sampling stations from 2004, 2005, and 2006 .......... 33

Table 6-1. Number of skinks and other reptiles captured by NTS area, site, and survey period.......... 53

Table 6-2. Western burrowing owl trapping results on the NTS, April-July 2006 ............................ 63

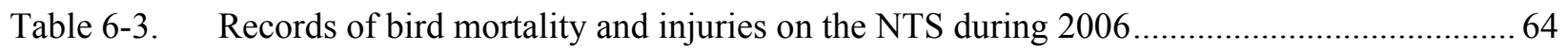

Table 6-4. Numbers of individual small mammals captured on trap lines on NTS in 2006............... 67

Table 6-5. Total numbers of individual small mammals captured at Trail Ridge from May 1980 to June 1982 compared to total individuals caught at EMAC trap lines in August 2006

Table 6-6. Results of maternity roost monitoring and $\mathrm{N}$ and $\mathrm{T}$ Tunnel monitoring including camera results and capture and capture and acoustic data.

Table 6-7. Number of horses observed on the NTS by age class, gender, and year.......

Table 6-8. Trends in deer counts per three-night session and an abundance index (deer $/ \mathrm{km})$ for two sampling regions on the NTS.

Table 6-9. Results of mountain lion camera survey during 2006 


\section{LIST OF TABLES (Cont'd)}

Table 7-1. Results of West Nile Virus (WNV) surveillance on the NTS in 2006 .............................90

Table 7-2. Hydrology and disturbance data recorded at natural water sources on the NTS................ 93

Table 7-3. Number of wildlife species observed or inferred at NTS natural water sources

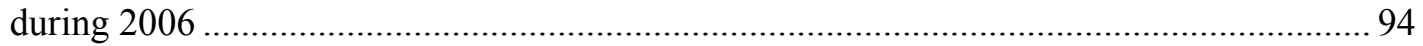

Table 7-4. Results of monitoring plastic-lined sumps for wildlife mortality at the NTS for 2006 ....... 95

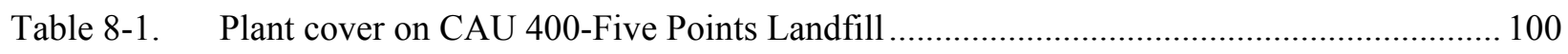

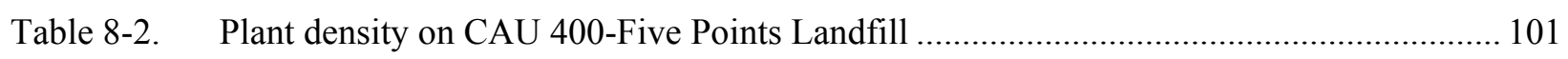

Table 8-3. Plant cover on CAU 400-Bomblet Pit......................................................................... 102

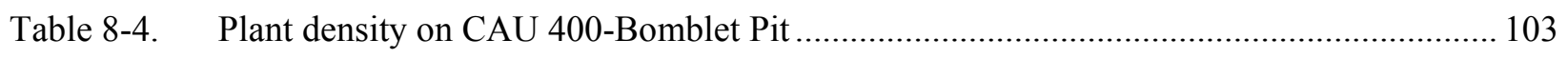

Table 8-5. Plant cover on CAU 426-Cactus Springs Waste Trenches: Staging Area ...................... 104

Table 8-6. Plant density on CAU 426-Cactus Springs Waste Trenches: Staging Area..................... 105

Table 8-7. Plant cover on CAU 404-Rollercoaster Sewage Lagoons: Staging Area......................... 106

Table 8-8. Plant density on CAU 404-Rollercoaster Sewage Lagoons: Staging Area...................... 107

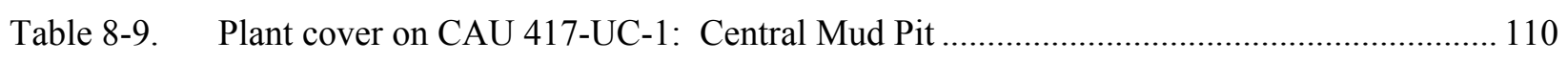

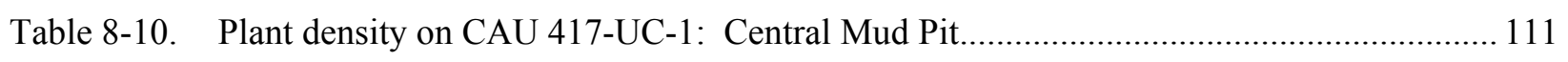

Table 8-11. Plant cover at CAU 426-Cactus Springs Waste Trenches: Cover cap ........................... 113

Table 8-12. Plant density at CAU 426-Cactus Springs Waste Trenches: Cover cap ......................... 114

Table 8-13. Percent plant cover at CAU 404-Rollercoaster Sewage Lagoons: Cover cap................... 115

Table 8-14. Plant density at CAU 404-Rollercoaster Sewage Lagoons: Cover cap............................ 116

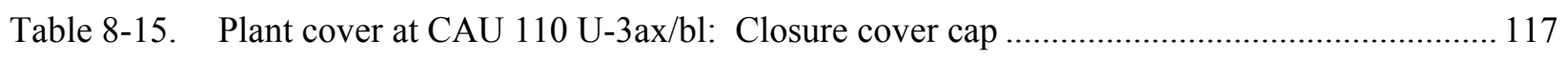

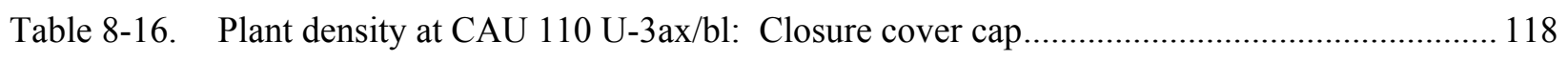

Table 8-17. Results of seeding trials at the Shoshone Mountain Fire burn location ........................... 122 
THIS PAGE IS INTENTIONALLY LEFT BLANK 


\section{ACRONYMS AND ABBREVIATIONS}

\begin{tabular}{|c|c|}
\hline ac & acre \\
\hline ASP & Advanced Spectroscopic Portal \\
\hline $\mathrm{BN}$ & Bechtel Nevada \\
\hline CAS & Corrective Action Site \\
\hline CAU & Corrective Action Unit \\
\hline CDC & Centers for Disease Control \\
\hline CEF & Critical Experiments Facility \\
\hline $\mathrm{cm}$ & centimeter \\
\hline CNTA & Central Nevada Test Area \\
\hline CWA & Clean Water Act \\
\hline CY & calendar year \\
\hline DAF & Device Assembly Facility \\
\hline DOE & U.S. Department of Energy \\
\hline $\mathrm{DOE} / \mathrm{NV}$ & U.S. Department of Energy, Nevada Operations Office \\
\hline EGIS & Ecological Geographic Information System \\
\hline EIS & Environmental Impact Statement \\
\hline ELU & Ecological Landform Unit \\
\hline EMAC & Ecological Monitoring and Compliance \\
\hline ER & Environmental Restoration \\
\hline ESA & Endangered Species Act \\
\hline $\mathrm{ft}$ & feet \\
\hline $\mathrm{ft}^{2}$ & square feet \\
\hline FWS & U.S. Fish and Wildlife Service \\
\hline FY & fiscal year \\
\hline GIS & Geographic Information System \\
\hline GPS & Global Positioning System \\
\hline ha & hectare \\
\hline in. & inch \\
\hline $\mathrm{kg} / \mathrm{ha}$ & kilogram per hectare \\
\hline $\mathrm{km}$ & kilometer \\
\hline
\end{tabular}




\section{ACRONYMS AND ABBREVIATIONS (Cont'd)}

$\begin{array}{ll}\text { LANL } & \text { Los Alamos National Laboratory } \\ \mathrm{lbs} / \mathrm{ac} & \text { pounds per acre } \\ \mathrm{m} & \text { meter } \\ \mathrm{m}^{2} & \text { square meters } \\ \mathrm{mi} & \text { mile } \\ \text { NAC } & \text { Nevada Administrative Code } \\ \text { NSTec } & \text { National Security Technologies, LLC } \\ \text { NNHP } & \text { Nevada Natural Heritage Program } \\ \text { NNPS } & \text { Nevada Native Plant Society } \\ \text { NNSA/NSO } & \text { U.S. Department of Energy, National Nuclear Security Administration } \\ & \text { Nevada Site Office } \\ \text { NPTEC } & \text { Non-Proliferation Test and Evaluation Complex } \\ \text { NTS } & \text { Nevada Test Site } \\ \text { PDF } & \text { Portable Document Format File } \\ \text { PLS } & \text { pure live seed } \\ \text { RMP } & \text { Resource Management Plan } \\ \text { SOC } & \text { Special Operations Center } \\ \text { TTR } & \text { Tonopah Test Range } \\ \text { UNLV } & \text { University of Nevada, Las Vegas } \\ \text { USACE } & \text { U.S. Army Corps of Engineers } \\ \text { USGS } & \text { West Nile Virus } \\ \text { WNV } & \end{array}$




\section{$1.0 \quad$ INTRODUCTION}

In accordance with U.S. Department of Energy Order (DOE) Order 450.1, "Environmental Protection Program," the Office of the Assistant Manager for Safety Programs of the U.S. Department of Energy, National Nuclear Security Administration Nevada Site Operations Office (NNSA/NSO) requires ecological monitoring and biological compliance support for activities and programs conducted at the Nevada Test Site (NTS). National Security Technologies, LLC (NSTec), Ecological Services has implemented the Ecological Monitoring and Compliance (EMAC) Program to provide this support. EMAC is designed to ensure compliance with applicable laws and regulations, delineate and define NTS ecosystems, and provide ecological information that can be used to predict and evaluate the potential impacts of proposed projects and programs on those ecosystems.

This report summarizes the program's activities conducted by NSTec during the calendar year 2006 . Monitoring tasked during 2006 included eight program areas: (a) biological surveys, (b) desert tortoise compliance, (c) ecosystem mapping and data management, (d) sensitive plant monitoring, (e) sensitive and protected/regulated animal monitoring, (f) habitat monitoring, (g) habitat restoration monitoring, and (h) biological monitoring at the Nonproliferation Test and Evaluation Complex (NPTEC). The following sections of this report describe work performed under these eight areas. 
THIS PAGE IS INTENTIONALLY LEFT BLANK 


\section{$2.0 \quad$ BIOLOGICAL SURVEYS}

Biological surveys are performed at proposed project sites where land disturbing activities are proposed. The goal is to minimize adverse effects of land disturbance on sensitive and protected/regulated plant and animal species (Table 2-1), their associated habitat, and important biological resources. Sensitive species are defined as species that are at risk of extinction or serious decline or whose long-term viability has been identified as a concern. They include species on the Nevada Natural Heritage Program (NNHP) sensitive plant and animal lists and bat species ranked as moderate or high in the Nevada Bat Conservation Plan Bat Species Risk Assessment. Protected/regulated species are those that are protected or regulated by federal or state law. Many species are both sensitive and protected/regulated (Table 2-1). Important biological resources include such things as cover sites, nest or burrow sites, roost sites, or water sources important to sensitive species. Survey reports are written to document species and resources found, and to provide mitigation recommendations.

\subsection{Sites Surveyed and Sensitive and Protected/Regulated Species Observed}

During 2006, biological surveys for 34 projects were conducted on or near the NTS (Figure 2-1, Table 2-2). For some of the projects, multiple sites were surveyed (Figure 2-1). A total of 342.11 hectares (ha) (845.37 acres [ac]) was surveyed for the projects (Table 2-2). Twenty one of the projects were within the range of the threatened desert tortoise (Gopherus agassizii). Sensitive and protected/regulated species and important biological resources found included: two inactive tortoise burrows, two burrows being used by burrowing owls, several horses, three active predator burrows, mature Joshua trees, yuccas and cacti, one bird nest with two eggs, one barn owl, and two great-horned owls (Table 2-2). NSTec provided to each project manager a written summary report of all survey findings and mitigation recommendations, where applicable (Table 2-2). All burrows, except rodent burrows, were flagged and avoided during construction activities.

\subsection{Potential Habitat Disturbance}

Surveys are conducted at old industrial or nuclear weapons testing sites whenever vegetation has reinvaded a site or it is suspected that a sensitive or protected/regulated species may be found. For example, tortoises may move through revegetated earthen sumps and may be concealed under vegetation during activities where heavy equipment is used. Preactivity surveys are conducted at such revegetated sites to ensure that desert tortoises are not in harm's way. Also, burrowing owls frequently inhabit burrows and culverts at disturbed sites, so preactivity surveys are conducted to ensure that adults, eggs, and nestlings in burrows are not harmed.

Twenty two of the projects for which surveys were conducted were entirely on sites previously disturbed (e.g., building sites, industrial waste sites, existing well pads, road shoulders) (Table 2-2). Thirteen projects were located either partially or entirely in areas that had not been previously disturbed. These projects have the potential to disturb a total of 33.82 ha (83.57 ac). Most of the area that could be disturbed was associated with the Divine Strake tests (Project No. 06-12, 06-13), which deal with a proposed large explosion and soil movement (Table 2-2). 
Table 2-1. List of sensitive and protected/regulated species known to occur on or adjacent to the NTS.

\begin{tabular}{|c|c|c|}
\hline SENSITIVE PLANT SPECIES & Common Names & Status $^{a}$ \\
\hline \multicolumn{3}{|l|}{ Flowering Plant Species } \\
\hline Astragalus beatleyae & Beatley milkvetch & $\mathrm{W}, 5$ years \\
\hline Astragalus funereus & Black woolypod & $\mathrm{W}, 5$ years \\
\hline Astragalus oopherus var. clokeyanus & Clokey eggvetch & $\mathrm{W}, 5$ years \\
\hline Eriogonum concinnum & Darin buckwheat & $\mathrm{W}, 5$ years \\
\hline Eriogonum heermannii var. clokeyi & Clokey buckwheat & $\mathrm{W}, 5$ years \\
\hline Ivesia arizonica var. saxosa & Rock purpusia & $\mathrm{W}, 5$ years \\
\hline Lathyrus hitchcockianus & Bullfrog Hills peavine & $\mathrm{W}, 5$ years \\
\hline Phacelia beatleyae & Beatley scorpionflower & $\mathrm{W}, 10$ years \\
\hline Arctomecon merriamii & White bearpoppy & $\mathrm{W}, 10$ years \\
\hline Camissonia megalantha & Cane Spring suncup & $\mathrm{W}, 10$ years \\
\hline Cymopterus ripleyi var. saniculoides & Sanicle biscuitroot & $\mathrm{W}, 10$ years \\
\hline Frasera pahutensis & Pahute green gentian & $\mathrm{W}, 10$ years \\
\hline Galium hilendiae ssp. kingstonense & Kingston Mountains bedstraw & $\mathrm{W}, 10$ years \\
\hline Hulsea vestita ssp. inyoensis & Pumice alpinegold & $\mathrm{W}, 10$ years \\
\hline Penstemon fruticiformis var. armagosae & Death Valley beardstongue & $\mathrm{T}, 5$ years \\
\hline Penstemon pahutensis & Pahute Mesa beardstongue & $\mathrm{W}, 10$ years \\
\hline Phacelia filiae & Clarke phacelia & $\mathrm{W}, 10$ years \\
\hline Phacelia mustelina & Weasel phacelia & $\mathrm{W}, 10$ years \\
\hline Phacelia parishii & Parish phacelia & $\mathrm{W}, 10$ years \\
\hline \multicolumn{3}{|l|}{ Moss Species } \\
\hline Entosthodon planoconvexus & Planoconvex entosthodon & $\mathrm{W}, 5$ years \\
\hline \multicolumn{3}{|l|}{ PROTECTED/REGULATED PLANT SPECIES } \\
\hline Cactaceae & Cacti (18 species) & $\mathrm{CY}$ \\
\hline Agavaceae & Yucca (3 species), Agave (1 species) & $\mathrm{CY}$ \\
\hline Pinus monophylla/Juniperus osteosperma & Pinyon/Juniper & $\mathrm{CY}$ \\
\hline
\end{tabular}


Table 2-1. List of sensitive and protected/regulated species known to occur on or adjacent to the NTS. (Cont'd)

\begin{tabular}{|c|c|c|}
\hline SENSITIVE ANIMAL SPECIES & Common Name & Status $^{a}$ \\
\hline \multicolumn{3}{|l|}{ Mollusk Species } \\
\hline Pyrgulopsis turbatrix & Southeast Nevada springsnail & $\mathrm{S}, \mathrm{A}$ \\
\hline \multicolumn{3}{|l|}{ Reptile Species } \\
\hline Eumeces gilberti rubricaudatus & Western red-tailed skink & $\mathrm{S}, \mathrm{E}$ \\
\hline Gopherus agassizii & Desert tortoise & LT, S, NP, IA \\
\hline \multicolumn{3}{|l|}{ Bird Species } \\
\hline Accipiter gentilis & Northern goshawk & S, NPS, IA \\
\hline Athene cunicularia hypugaea & Western burrowing owl & $\mathrm{S}, \mathrm{NP}, \mathrm{A}$ \\
\hline Buteo regalis & Ferruginous hawk & S, NP, IA \\
\hline Buteo swainsoni & Swainson's hawk & $\mathrm{S}, \mathrm{NP}, \mathrm{IA}$ \\
\hline Chlidonias niger & Black tern & $\mathrm{S}, \mathrm{NP}, \mathrm{IA}$ \\
\hline Coccyzus americanus & Western yellow-billed cuckoo & S, NPS, IA \\
\hline Falco peregrinus anatum & American peregrine falcon & $<\mathrm{LE}, \mathrm{S}, \mathrm{NPE}, \mathrm{IA}$ \\
\hline Gavia immer & Common loon & $\mathrm{S}, \mathrm{NP}, \mathrm{IA}$ \\
\hline Haliaeetus leucocephalus & Bald eagle & $\begin{array}{l}\text { LT-PD, EA, S, NPE, } \\
\text { IA }\end{array}$ \\
\hline Ixobrychus exillis hesperis & Western least bittern & $\mathrm{S}, \mathrm{NP}, \mathrm{IA}$ \\
\hline Phainopepla nitens & Phainopepla & $\mathrm{S}, \mathrm{NP}, \mathrm{IA}$ \\
\hline Plegadis chihi & White-faced ibis & $\mathrm{S}, \mathrm{NP}, \mathrm{IA}$ \\
\hline \multicolumn{3}{|l|}{ Mammal Species } \\
\hline Antrozous pallidus & Pallid bat & $\mathrm{M}, \mathrm{NP}, \mathrm{A}$ \\
\hline Corynorhinus townsendii pallescens & Townsend's big-eared bat & H, NPS, A \\
\hline Euderma maculatum & Spotted bat & $\mathrm{M}, \mathrm{NPT}, \mathrm{A}$ \\
\hline Lasionycteris noctivagans & Silver-haired bat & $\mathrm{M}, \mathrm{A}$ \\
\hline Lasiurus blossevillii & Western red bat & H, NPS, A \\
\hline
\end{tabular}




\begin{tabular}{lll}
$\begin{array}{l}\text { Table 2-1. List of sensitive and protected/regulated species known to occur on or adjacent to the } \\
\text { NTS. (Cont'd) }\end{array}$ & Common Name & Status \\
SENSITIVE ANIMAL SPECIES & Hoary bat & $\mathrm{M}, \mathrm{A}$ \\
\hline \hline Lasiurus cinereus & California myotis & $\mathrm{M}, \mathrm{A}$ \\
Myotis californicus & Small-footed myotis & $\mathrm{M}, \mathrm{A}$ \\
Myotis ciliolabrum & Long-eared myotis & $\mathrm{M}, \mathrm{A}$ \\
Myotis evotis & Fringed myotis & $\mathrm{H}, \mathrm{NP}, \mathrm{A}$ \\
Myotis thysanodes & Yuma myotis & $\mathrm{M}, \mathrm{A}$ \\
Myotis yumanensis & Western pipistrelle & $\mathrm{M}, \mathrm{A}$ \\
Pipistrellus hesperus & & \\
\hline \hline
\end{tabular}

\section{PROTECTED/REGULATED ANIMAL SPECIES}

Bird Species $^{b}$

\begin{tabular}{lll}
\hline Alectoris chukar & Chukar & $\mathrm{G}$ \\
Aquila chrysaetos & Golden eagle & EA, NP \\
Callipepla gambelii & Gambel's quail & $\mathrm{G}$ \\
Charadrius montanus & Mountain plover & PT, NP \\
Lanius ludovicianus & Loggerhead shrike & NPS \\
Oreoscoptes montanus & Sage thrasher & NPS \\
Spizella breweri & Brewer's sparrow & NPS \\
& & \\
\hline
\end{tabular}

\section{Mammal Species}

\begin{tabular}{|c|c|c|}
\hline Antilocapra americana & Pronghorn antelope & $\mathrm{G}$ \\
\hline Equus asinus & Burro & $\mathrm{H} \& \mathrm{~B}$ \\
\hline Equus caballus & Horse & $H \& B$ \\
\hline Puma concolor & Mountain lion & G \\
\hline Lynx rufus & Bobcat & $\mathrm{F}$ \\
\hline Microdipodops megacephalus & Dark kangaroo mouse & NP \\
\hline Microdipodops pallidus & Pale kangaroo mouse & NP \\
\hline Ovis canadensis nelsoni & Desert bighorn sheep & $\mathrm{G}$ \\
\hline Odocoileus hemionus & Mule deer & G \\
\hline Sylvilagus audubonii & Audubon's cottontail & G \\
\hline Sylvilagus nuttallii & Nuttall's cottontail & $\mathrm{G}$ \\
\hline
\end{tabular}


Table 2-1. List of sensitive and protected/regulated species known to occur on or adjacent to the NTS. (Cont'd)

\begin{tabular}{lll} 
Table 2-1 Continued & Common Name & Status $^{\mathbf{a}}$ \\
\hline \hline Tadarida brasiliensis & Brazilian free-tailed bat & $\mathrm{NP}$ \\
Urocyon cinereoargenteus & Gray fox & $\mathrm{F}$ \\
Vulpes velox macrotis & Kit fox & $\mathrm{F}$ \\
\hline \hline
\end{tabular}

atatus Codes:

Endangered Species Act, U.S. Fish and Wildlife Service

LT - Listed Threatened

PT - Proposed for listing as Threatened

PD - Proposed for delisting

$<$ LE - Former listed endangered species

U.S. Department of Interior

H\&B - Protected under Wild Free Roaming Horses and Burros Act

EA - Protected under Bald and Golden Eagle Act

State of Nevada-Animals

$\mathrm{S} \quad$ - Nevada Natural Heritage Program-Sensitive Animal Taxa

NPE - Nevada Protected-Endangered, species protected under Nevada Administrative Code (NAC) 503

NPT - Nevada Protected-Threatened, species protected under NAC 503

NPS - Nevada Protected-Sensitive, species protected under NAC 503

NP - Nevada Protected, species protected under NAC 503

G - Regulated as game species

F - Regulated as fur-bearer species

$\underline{\text { State of Nevada-Plants }}$

T - Nevada Natural Heritage Program --At Risk Plant and Lichen Taxa, Threatened: believed to meet the ESA definition of Threatened

W - Nevada Natural Heritage Program --At Risk Plant and Lichen Taxa, Watch-list species: potentially vulnerable to becoming Threatened or Endangered

CY - Protected as a cactus, yucca, or Christmas tree

Long-term Animal Monitoring Status for the Nevada Test Site (NTS)

$\begin{array}{lll}\mathrm{A} & - & \text { Active } \\ \mathrm{IA} & - & \text { Inactive } \\ \mathrm{E} & - & \text { Evaluate }\end{array}$

Long-term Plant Monitoring Status for the NTS)

5 years - Monitor a minimum of once every 5 years

10 years - Monitor a minimum of once every 10 years

Nevada Bat Conservation Plan - Bat Species Risk Assessment

$\mathrm{H}-$ High

M - Moderate

b

All bird species on the NTS are protected by the Migratory Bird Treaty Act except for Chukar, Gambel's quail, English house sparrow, Rock dove, and European starling. 


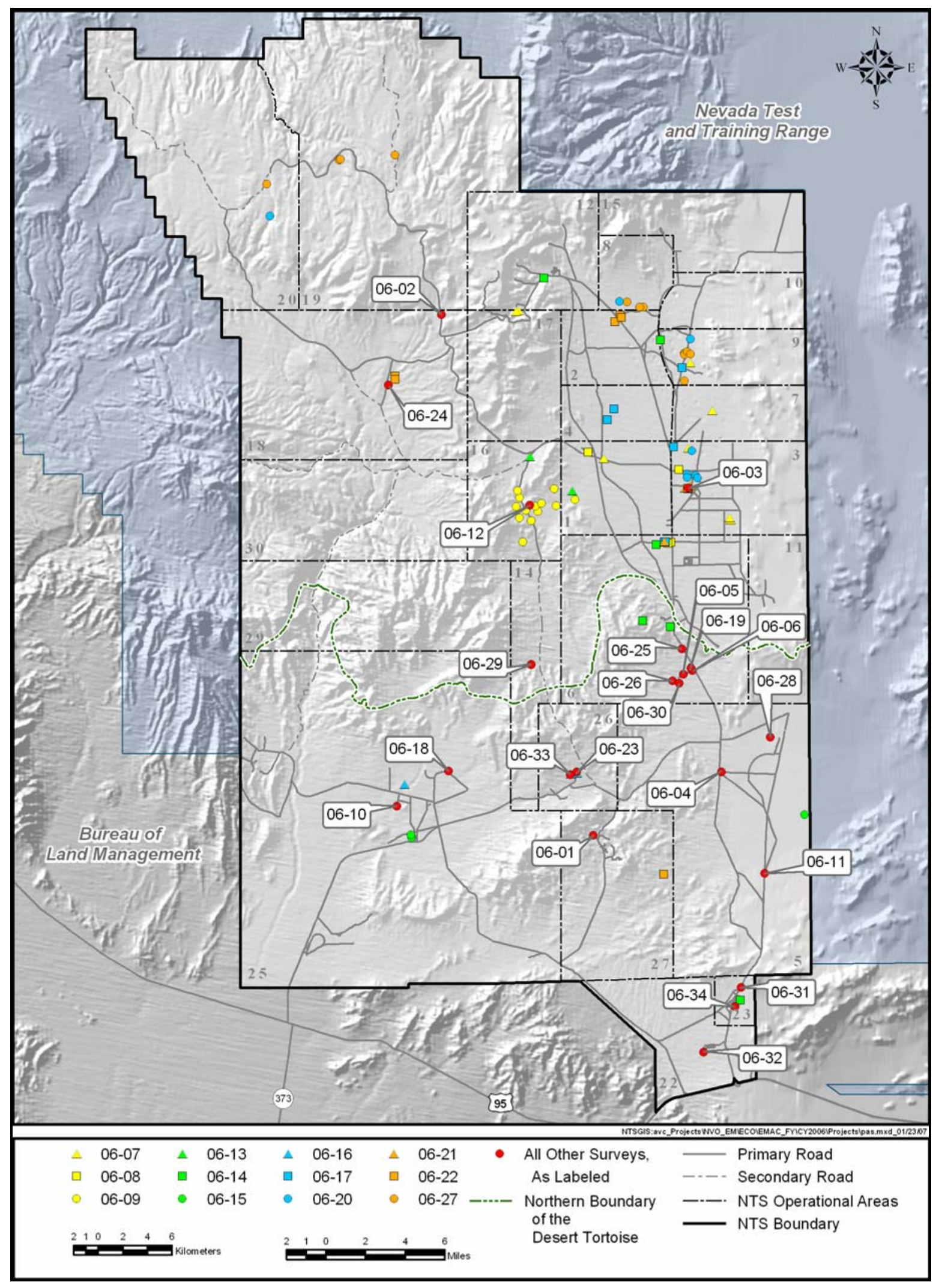

Figure 2-1. Biological surveys conducted on the NTS during 2006. 
Table 2-2. Summary of biological surveys conducted on the NTS during 2006.

\begin{tabular}{|c|c|c|c|c|c|}
\hline $\begin{array}{l}\text { Project } \\
\text { No. }\end{array}$ & Project & $\begin{array}{c}\text { Important } \\
\text { Species/ Resources } \\
\text { Found }\end{array}$ & $\begin{array}{c}\text { Area } \\
\text { Surveyed in } \\
\text { ha (ac) }\end{array}$ & $\begin{array}{l}\text { Proposed Project } \\
\text { Area in Undisturbed } \\
\text { Habitat in ha (ac) }\end{array}$ & $\begin{array}{c}\text { Mitigation } \\
\text { Recommendations }\end{array}$ \\
\hline $06-01$ & Super Kukla & None & $3.45(8.53)$ & 0 & None \\
\hline $06-02$ & Castle Rock Substation & Horses & $0.65(1.61)$ & $0.37(2.18)$ & Avoid wild horses \\
\hline $06-03$ & Corrective Action Unit (CAU) 322 & $\begin{array}{l}1 \text { barn owl; } 2 \text { great-horned owls \& } \\
\text { their nest with } 2 \text { eggs }\end{array}$ & $0.25(0.62)$ & 0 & Monitor nest during work activity \\
\hline $06-04$ & Area 5 Water Tanks & None & $0.58(1.46)$ & $0.38(0.94)$ & None \\
\hline $06-05$ & ASP fenceline & Joshua trees/cacti & $7.7(19.03)$ & $0.19(0.47)$ & Avoid Joshua trees/cacti if possible \\
\hline $06-06$ & DAF roadside vegetation removal & None & $5.75(12.78)$ & 0 & None \\
\hline $06-07$ & CAU 137 & None & $9.54(23.56)$ & 0 & None \\
\hline $06-08$ & CAU 555 & None & $1.82(4.50)$ & 0 & None \\
\hline 06-09 & Divine Strake & None & $3.25(8.03)$ & 0 & None \\
\hline $06-10$ & CAU 168 & 2 potential tortoise burrows & $9.63(23.80)$ & $0.89(2.21)$ & Avoid burrow by $10 \mathrm{~m}(32.8 \mathrm{ft})$ \\
\hline $06-11$ & 5-01 roadside mowing & None & $4.08(10.08)$ & 0 & None \\
\hline $06-12$ & Divine Strake Blast area & None & $23.63(58.39)$ & $18.90(46.70)$ & None \\
\hline $06-13$ & Divine Strake cable line/access & Joshua trees and cacti & $1.70(4.20)$ & $0.23(0.57)$ & Avoid Joshua trees, cacti \\
\hline $06-14$ & CAU 538 & None & $3.35(8.29)$ & 0 & None \\
\hline $06-15$ & CAU 214 & None & $0.67(1.66)$ & 0 & None \\
\hline $06-16$ & CAU 168 & None & $1.13(2 . .79)$ & 0 & None \\
\hline
\end{tabular}


Table 2-2. Summary of biological surveys conducted on the NTS during 2006. (Cont'd)

\begin{tabular}{|c|c|c|c|c|c|}
\hline $\begin{array}{l}\text { Project } \\
\text { Number }\end{array}$ & Project & $\begin{array}{l}\text { Important } \\
\text { Species/ Resources } \\
\text { Found }\end{array}$ & $\begin{array}{l}\text { Area } \\
\text { Surveyed in } \\
\text { ha (ac) }\end{array}$ & $\begin{array}{l}\text { Proposed Project } \\
\text { Area in } \\
\text { Undisturbed } \\
\text { Habitat in ha (ac) }\end{array}$ & $\begin{array}{c}\text { Mitigation } \\
\text { Recommendations }\end{array}$ \\
\hline $06-17$ & CAU 139 & Two active predator burrows & $4.10(10.13)$ & 0 & Avoid burrows \\
\hline $06-18$ & CAU 115 & None & $6.00(14.80)$ & 0 & None \\
\hline 06-19 & CEF project-construction facility & Yuccas and cacti & $4.34(10.72)$ & $2.31(5.71)$ & Avoid Yuccas and cacti if possible \\
\hline $06-20$ & CAU 542 & None & $0.76(1.88)$ & 0 & None \\
\hline $06-21$ & CAU 516 & None & $0.99(2.45)$ & 0 & None \\
\hline $06-22$ & CAU 166 & None & $6.29(15.54)$ & 0 & None \\
\hline $06-23$ & CAU 168 CAS 26-08-01 & Mojave Yuccas & $2.50(6.18)$ & $1.40(3.46)$ & Avoid Mojave Yuccas if possible \\
\hline $06-24$ & Chicken Little & $\begin{array}{l}\text { Several burrows with one } \\
\text { burrowing owl }\end{array}$ & $\begin{array}{l}10.00 \\
(24.70)\end{array}$ & $\begin{array}{c}8.00(19.77) \\
(19.77)\end{array}$ & $\begin{array}{l}\text { None, burrows found in post activity } \\
\text { survey/no preactivity survey } \\
\text { conducted }\end{array}$ \\
\hline $06-25$ & Mercury Highway blading & None & $\begin{array}{c}15.25 \\
(37.68)\end{array}$ & 0 & None \\
\hline $06-26$ & Pad west of DAF & Predator burrow & $0.49(1.21)$ & $0.03(0.09)$ & Avoid predator burrow if possible \\
\hline $06-27$ & CAU 177 & None & $5.49(13.57)$ & 0 & None \\
\hline $06-28$ & Area 5 Lysimeter solar panels & None & $0.03(0.07)$ & 0 & None \\
\hline 06-29 & T-Genie & None & $1.00(2.47)$ & $1.00(2.47)$ & None \\
\hline $06-30$ & Seismic Survey DAF & None & $\begin{array}{c}72.37 \\
(178.83)\end{array}$ & 0 & None \\
\hline $06-31$ & Mercury Highway mowing & None & $\begin{array}{c}120.00 \\
(296.53)\end{array}$ & 0 & None \\
\hline
\end{tabular}


Table 2-2. Summary of biological surveys conducted on the NTS during 2006. (Cont'd)

\begin{tabular}{|c|c|c|c|c|c|}
\hline $\begin{array}{l}\text { Project } \\
\text { Number }\end{array}$ & Project & $\begin{array}{c}\text { Important } \\
\text { Species/ Resources } \\
\text { Found }\end{array}$ & $\begin{array}{c}\text { Area } \\
\text { Surveyed in } \\
\text { ha (ac) }\end{array}$ & $\begin{array}{l}\text { Proposed Project } \\
\text { Area in } \\
\text { Undisturbed } \\
\text { Habitat in ha (ac) }\end{array}$ & $\begin{array}{c}\text { Mitigation } \\
\text { Recommendations }\end{array}$ \\
\hline $06-32$ & Desert Rock roadside grading & Yuccas and Joshua trees & $\begin{array}{c}10.19 \\
(25.18)\end{array}$ & 0 & $\begin{array}{l}\text { Avoid Joshua trees and yuccas if } \\
\text { possible }\end{array}$ \\
\hline $06-33$ & Firebreak for CAS 26-19-02 & None & $0.71(1.71)$ & $0.12(0.30)$ & None \\
\hline \multirow[t]{2}{*}{$06-34$} & Grading of Driving Range & None & $\underline{4.42}(10.92)$ & 0 & None \\
\hline & & $\begin{array}{c}\text { Totals in ha } \\
\text { (ac) }\end{array}$ & $\begin{array}{c}342.11 \\
(845.37)\end{array}$ & $\begin{array}{c}33.82 \\
(83.57)\end{array}$ & \\
\hline
\end{tabular}


Ten of the projects that will cause new disturbances occur in areas designated as important habitat (Table 2-3, Figure 2-2). During vegetation mapping of the NTS, Ecological Landform Units (ELUs) were evaluated and some were identified as Pristine (having few man-made disturbances), Unique (containing uncommon biological resources such as a natural wetland), Sensitive (containing vegetation associations which recover very slowly from direct disturbance), and Diverse (having high plant species diversity) (DOE/NV, 1998). A single ELU could be classified as more than one type of these important habitats.

Figure 2-2 shows the distribution of these important habitats which were ranked so that pristine habitat overlays unique, which then overlays sensitive, which then overlays diverse habitat. The expected area to be disturbed in important habitat due to 2006 projects is 38.43 ha (94.96 ac) (Table 2-3). Since fiscal year (FY) 1999, a tally of all acreage proposed for disturbance within important habitats has been kept (Table 2-3). This tally may be used in the future to estimate the area and rate of establishment of invasive species into these habitats. Land-disturbing activities are known to cause the spread of invasive species such as Bromus matridensis spp. rubens (red brome) into areas of the NTS where they have not previously occurred. Such nonnative weeds can degrade important habitats by decreasing plant biodiversity and increasing the risk and spread of wildfires. The monitoring and control of invasive plants on federal lands is encouraged under Executive Order 13112, Invasive Species.

Table 2-3. Total area in hectares (acres in parenthesis) proposed for disturbance within important habitats in 2006 and over the past eight fiscal years.

\begin{tabular}{|c|c|c|c|c|c|}
\hline $\begin{array}{l}\text { Project } \\
\text { No. }\end{array}$ & Project Name & $\begin{array}{l}\text { Pristine } \\
\text { Habitat }\end{array}$ & $\begin{array}{l}\text { Unique } \\
\text { Habitat }\end{array}$ & $\begin{array}{c}\text { Sensitive } \\
\text { Habitat }\end{array}$ & $\begin{array}{l}\text { Diverse } \\
\text { Habitat }\end{array}$ \\
\hline $06-05$ & ASP fenceline & 0 & $0.19(0.57)$ & 0 & 0 \\
\hline $06-10$ & CAU 168 CAS 25-16-02 & 0 & 0 & $0.89(2.20)$ & 0 \\
\hline $06-12$ & Divine Strake blast area & 0 & 0 & $18.90(46.70)$ & 0 \\
\hline $06-13$ & Divine Strake cable line/access & 0 & 0 & $0.23(0.57)$ & 0 \\
\hline 06-19 & CEF project construction facility & 0 & $2.31(5.71)$ & 0 & 0 \\
\hline $06-23$ & CAU 168 CAS 26-08-01 & 0 & 0 & $1.40(3.46)$ & 0 \\
\hline $06-26$ & Pad west of DAF & 0 & $0.03(0.74)$ & 0 & 0 \\
\hline $06-29$ & T-Genie & 0 & 0 & $1.00(2.47)$ & 0 \\
\hline $06-30$ & Seismic Survey at DAF & 0 & 0.00 & 0 & 0 \\
\hline \multirow[t]{5}{*}{$06-33$} & Firebreak for CAS 26-19-02 & $0.12(0.30)$ & 0 & $4.36(10.77)$ & 0 \\
\hline & Total ha 2006 & 0.12 & 2.53 & 35.78 & $\mathbf{0}$ \\
\hline & (ac) & $(0.30)$ & $(6.25)$ & $(88.41)$ & \\
\hline & Grand Total ha 1999 - 2006 & 9.20 & 11.85 & 181.86 & 79.47 \\
\hline & (ac) & & (29.28) & (449.39) & (196.37) \\
\hline
\end{tabular}




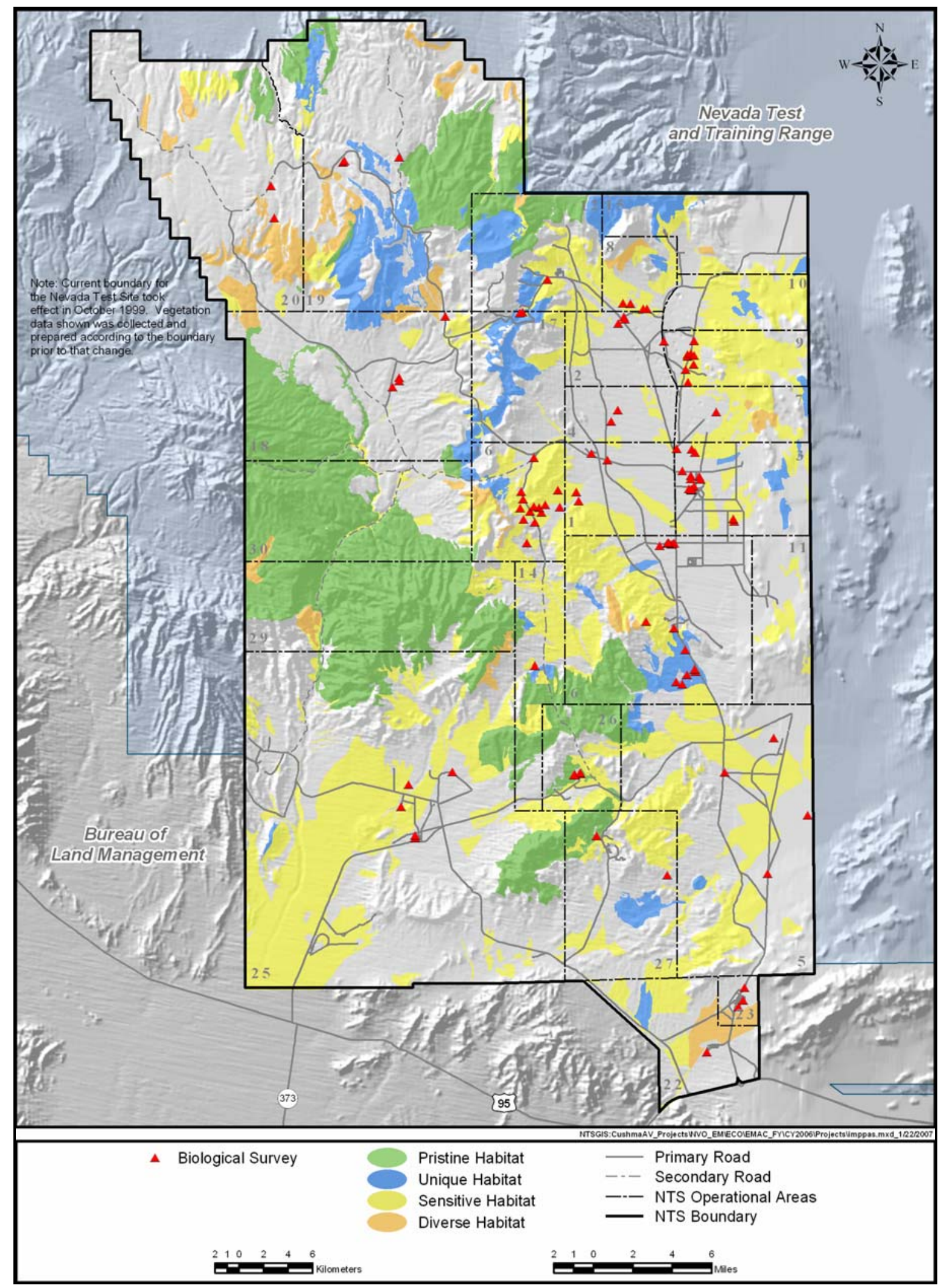

Figure 2-2. Biological surveys conducted in important habitats of the NTS during 2006. 


\subsection{Coordination with Biologists and Wildlife Agencies}

At two active project sites, NSTec biologists found bird nests with eggs. One was a kestrel nest in a crane at U1a in Area 1. After consulting with the U.S. Fish and Wildlife Service (FWS) permission was given to take the eggs to Lisa Ross with the Wild Wing Project, Inc., where eggs were incubated, but were found to be nonviable.

The other nest was a great-horned owl nest with two eggs at Area 3, the 03-3C-02 Post Shot Shop (Corrective Action Unit [CAU] 322), which was located in late February. After consulting with FWS, the project proceeded with an NSTec biologist monitoring the nest while work was being performed.

Disturbance to the nest was kept to a minimum and the project was completed without any apparent harm to the owls. The nest was checked later in April and one chick was observed at the nest. 


\subsection{DESERT TORTOISE COMPLIANCE}

Desert tortoises occur within the southern one-third of the NTS. This species is listed as threatened under the Endangered Species Act (ESA). In December 1995, NNSA/NSO completed consultation with the FWS concerning the effects of NNSA/NSO activities, as described in the Final Environmental Impact Statement for the Nevada Test Site and Off-Site Locations in the State of Nevada (U.S. Department of Energy, Nevada Operations Office [DOE/NV], 1996), on the desert tortoise. A final Biological Opinion (Opinion) (FWS, 1996) was received from FWS in August 1996. The Opinion concluded that the proposed activities on the NTS were not likely to jeopardize the continued existence of the Mojave population of the species and that no critical habitat would be destroyed or adversely modified. All terms and conditions listed in the Opinion must be followed when activities are conducted within the range of the desert tortoise on the NTS.

The Desert Tortoise Compliance task of EMAC was developed to implement the terms and conditions of the Opinion, document compliance actions taken by NNSA/NSO, and assist NNSA/NSO in FWS consultations. The terms and conditions that were implemented by NSTec staff biologists in 2006 included: (a) conducting clearance surveys at project sites within 1 to 7 days from the start of project construction, (b) ensuring that environmental monitors are onsite during heavy equipment operation, and (c) preparing an annual compliance report submitted to the FWS.

\subsection{Project Surveys and Compliance Documentation}

Biologists conducted biological and desert tortoise clearance surveys prior to ground-disturbing activities for 21 proposed projects (27 sites) within the range of desert tortoise on the NTS (Table 3-1, Figure 3-1). Most of these projects were in, or immediately adjacent to, existing facilities and disturbances.

Only two inactive tortoise burrows were found during tortoise clearance surveys (Table 3-2). These inactive tortoise burrows (Project No. 06-10) were outside of the immediate construction area so they were flagged and avoided during project activities.

Seven projects were initiated in previously undisturbed desert tortoise habitat. Project 06-05 did only minor damage with no loss of desert tortoise habitat (Table 3-2). This project is located just east of the Device Assembly Facility (DAF) in Area 6. Project 06-10 disturbed 0.89 ha (2.21 ac) of undisturbed habitat in northern Jackass Flats south of Engine Maintenance, Assembly, and Disassembly Building (E-MAD) facility in Area 25. Project 06-19 disturbed 2.31 ha (5.71 ac) of undisturbed habitat east of the DAF in Area 6. Project 06-23 disturbed 0.03 ha $(0.07 \mathrm{ac})$ of desert tortoise habitat. The project is in Area 26, just east of the Phoenix facility. Project 06-30 also did only minor damage with no loss of desert tortoise habitat. This project is also located around the DAF in Area 6. The last project, 06-33, disturbed $0.12 \mathrm{ha}(0.30 \mathrm{ac})$ of undisturbed land in Area 26 near the Phoenix facility. NSTec Ecological Services ensured that onsite construction monitoring was conducted by a designated environmental monitor at all sites where clearance surveys were performed.

Post-activity surveys to quantify the acreage of tortoise habitat actually disturbed were conducted for five projects during this reporting period (Table 3-1). Post-activity surveys were not conducted if the projects were within the tortoise exclusion zone or if viable tortoise habitat was not found within the project area boundaries (due to previous disturbance) during the clearance survey and if the environmental monitor documented that the project stayed within its proposed boundaries. This year a total of 1.89 ha $(4.69 \mathrm{ac})$ of tortoise habitat was disturbed (Table 3-1). 
Table 3-1. Summary of tortoise compliance activities conducted by NSTec biologists during 2006.

\begin{tabular}{|c|c|c|c|}
\hline $\begin{array}{l}\text { Project } \\
\text { Number }\end{array}$ & Project & $\begin{array}{l}\text { Compliance Activities } \\
100 \% \text {-Coverage Clearance Survey }\end{array}$ & $\begin{array}{c}\text { Tortoise Habitat } \\
\text { Disturbed } \\
\text { ha ( ac) }\end{array}$ \\
\hline $06-01$ & Super Kukla CAU 118 & Yes* & $0(0)$ \\
\hline 06-04 & Area 5 Water Tanks ( 2 sites in exclusion zone) & Yes* & $0(0)$ \\
\hline $06-05$ & ASP fencing project & Yes, post-activity survey completed & $0(0)$ \\
\hline 06-06 & DAF access road & Yes* & $0(0)$ \\
\hline $06-10$ & CAU 168 CAS 25-16-01 & Yes, post-activity survey completed & $0.89(2.21)$ \\
\hline $06-11$ & 5-01 Roadside mowing & $\mathrm{Ye}^{*}$ & $0(0)$ \\
\hline $06-14$ & CAU $538 \quad 3$ CASs & Yes* & $0(0)$ \\
\hline $06-15$ & CAU 2143 CASs & Yes* & $0(0)$ \\
\hline $06-16$ & CAU 1683 CASs & Yes* & $0(0)$ \\
\hline $06-18$ & CAU 115 Test Cell A & Yes* & $0(0)$ \\
\hline 06-19 & CEF project & Yes, post-activity survey not completed yet & $\mathrm{TBD}^{* *}$ \\
\hline $06-22$ & CAU 166 CAS 5-19-02 & Yes* & $0(0)$ \\
\hline $06-23$ & CAU 168 CAS 26-08-01 & Yes, post-activity survey completed & $0.99(2.45)$ \\
\hline $06-25$ & Mercury Highway roadside mowing & Yes* & $0(0)$ \\
\hline $06-26$ & Pad near DAF & Yes* & $0.01(0.03)$ \\
\hline $06-28$ & Lysimeter Solar Panels & Yes* & $0(0)$ \\
\hline $06-30$ & Seismic survey - DAF & Yes, post-activity survey completed & $0(0)$ \\
\hline $06-31$ & Mercury Highway roadside mowing & Yes* & $0(0)$ \\
\hline $06-32$ & Desert Rock roadside grading & Yes* & $0(0)$ \\
\hline $06-33$ & Firebreak for CAS 26-19-02 & Yes, post-activity survey not completed yet & $\mathrm{TBD}^{* *}$ \\
\hline \multirow[t]{2}{*}{$05-34$} & Mercury Driving Range brushing & Yes* & $0(0)$ \\
\hline & & Total & 1.89 (4.69) \\
\hline
\end{tabular}

*Post-activity survey was unnecessary because project was located within previously-disturbed tortoise habitat or in the exclusion zone

$* * \mathrm{TBD}=$ To be determined when project is complete 


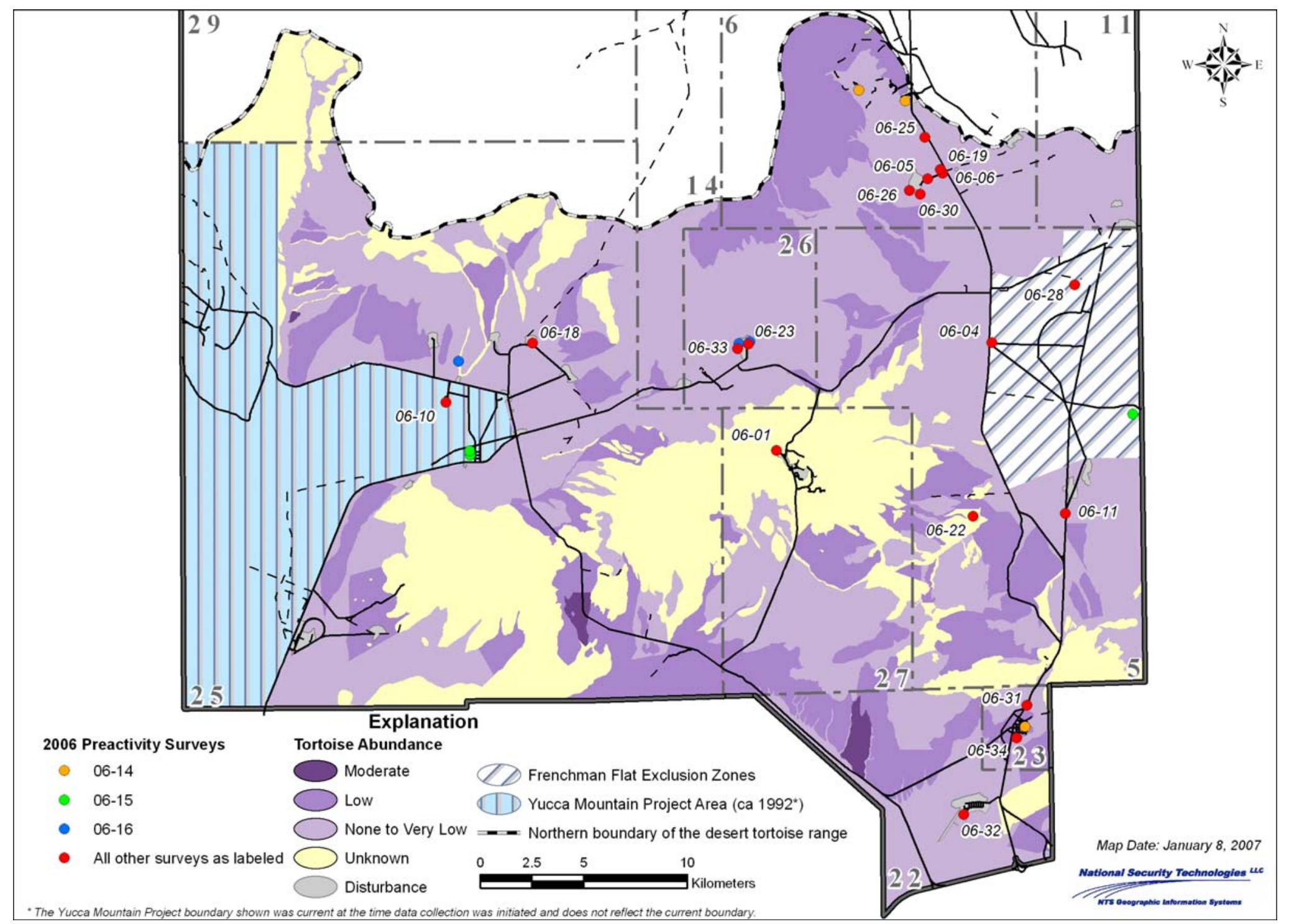

Figure 3-1. Biological surveys conducted in desert tortoise habitat on the NTS during 2006. 
In January 2007, NSTec submitted to NNSA/NSO the annual report that summarized tortoise compliance activities conducted on the NTS from January 1 through December 31, 2006. This report, required under the Opinion, contains: (a) the location and size of land disturbances that occurred within the range of the desert tortoise during the reporting period; (b) the number of desert tortoises injured, killed, or removed from project sites; (c) a map showing the location of all tortoises sighted on or near roads on the NTS; and (d) a summary of construction mitigation and monitoring efforts.

Compliance with the Opinion will ensure that the two goals of the NNSA/NSO's Resource Management Plan (DOE/NV, 1998) are being met; namely, that the desert tortoise is protected on the NTS and that the cumulative impacts on this species are minimized. In the Opinion, the FWS has determined that the "incidental take"1 of tortoises on the NTS and the cumulative acreage of tortoise habitat disturbed on the NTS are parameters to be measured and monitored annually. During this calendar year, the threshold levels established by the FWS for these parameters were not exceeded (Table 3-2). No desert tortoises were accidentally injured or killed, nor were any captured or displaced from project sites. One desert tortoise was killed along roadways within the NTS.

Table 3-2. Parameters and threshold values for desert tortoise monitoring on the NTS.

\begin{tabular}{|c|c|c|c|}
\hline Monitored Parameter & $\begin{array}{l}\text { Threshold } \\
\text { Value }\end{array}$ & Adaptive Management Action & $\begin{array}{l}2006 \text { Value of } \\
\text { Monitored } \\
\text { Parameter }\end{array}$ \\
\hline $\begin{array}{l}\text { Number of tortoises accidentally injured or killed as a } \\
\text { result of NTS activities per year }\end{array}$ & 3 & $\begin{array}{l}\text { Reinitiate consultation with } \\
\text { FWS }\end{array}$ & 0 \\
\hline $\begin{array}{l}\text { Number of tortoises captured and displaced from NTS } \\
\text { project sites per year }\end{array}$ & 10 & $\begin{array}{l}\text { Reinitiate consultation with } \\
\text { FWS }\end{array}$ & 0 \\
\hline $\begin{array}{l}\text { Number of tortoises taken in form of injury or mortality } \\
\text { on paved roads on the NTS by vehicles other than those } \\
\text { in use during a project }\end{array}$ & Unlimited & $\begin{array}{l}\text { Supplemental employee } \\
\text { education and bulletins }\end{array}$ & 1 \\
\hline $\begin{array}{l}\text { Number of total hectares (acres) of desert tortoise habitat } \\
\text { disturbed during NTS project construction since } 1992\end{array}$ & $1,220(3,015)$ & $\begin{array}{l}\text { Reinitiate consultation with } \\
\text { FWS }\end{array}$ & $110.25(272.43)$ \\
\hline
\end{tabular}

\subsection{Habitat Revegetation Plan for Loss of Tortoise Habitat}

Mitigation for the loss of tortoise habitat is required under the terms and conditions of the Opinion. The Opinion requires NNSA/NSO to perform either of two mitigation options: (a) prepay Clark County $\$ 1,741$ per each hectare ( $\$ 705$ for each acre) of habitat disturbed, or (b) revegetate disturbed habitat following specified criteria. Since 1992, NNSA/NSO has been using the balance of $\$ 81,000$ that NNSA/NSO deposited into a Clark County fund to pre-pay for the future disturbance of 101 ha (250 ac) of tortoise habitat on the NTS. As of December 31, 2006, this fund has been depleted and all new disturbances will have to pay the required

${ }^{1}$ To "take" a threatened or endangered species, as defined by the ESA, is to harass, harm, pursue, hunt, shoot, wound, kill, trap, capture, or collect, or attempt to engage in any such conduct. 
mitigation fee or revegetate the disturbances. It has been necessary to develop future strategies for funding including implementing habitat mitigation which occurred in 2005 so that work in tortoise habitat may continue without interruption in the future.

NSTec biologists prepared a site-specific plan to revegetate tortoise habitat as mitigation for one project. This plan was sent to FWS for approval but was not approved in time for revegetation in 2006. Revegetation will be initiated in 2007.

\subsection{Coordination with Other Biologists and Wildlife Agencies}

Three 8.5-ha (21-ac) circular enclosures in Rock Valley were constructed during 1962-1963 to study the effects of chronic, low-level ionizing radiation on the desert flora and fauna. Over the past decades, at least 24 tortoises have been found, individually marked, and periodically measured. In 2002 there were approximately 18 adult tortoises remaining in the enclosures; however, in 2003, Phil Medica of the U.S. Geological Survey (USGS) Las Vegas Office, NSTec biologists, and a team of volunteer biologists, found the remains of seven tortoises of known age. Two additional desert tortoises within the enclosures were lost in 2004 presumably to mountain lion predation. These plots were revisited twice in the fall of 2006 with Phil Medica to observe desert tortoises in the fenced plots. Five desert tortoises were found above ground, weighed, measured, and released back into the enclosures. One specimen was found dead and was salvaged. Areas around the enclosures were searched but no additional carcasses were observed.

\subsection{Biological Assessment for Chemical Testing at Port Gaston}

In February of 2006, NSTec scientists prepared a Biological Assessment of the potential impacts to desert tortoises for chemical tests that were being proposed at Port Gaston in Area 26. The Biological Assessment concluded that the proposed activities would not adversely affect desert tortoises or their habitat. NNSA/NSO requested informal consultation with FWS in February 2006. FWS agreed with our assessment that there would be no adverse impact on desert tortoises provided that the mitigation measures were followed as specified in the Biological Assessment. As per the assessment, the site was surveyed prior to testing. No tortoises were found in the area.

\subsection{Biological Opinion for Security Activities at the DAF}

In spring of 2006, NNSA/NSO and NSTec scientists met with FWS personnel to discuss security activities at the DAF and if those activities would be considered as part of the existing NTS Biological Opinion. The FWS concluded that the activities were not covered and that NNSA/NSO should prepare a Biological Assessment of those security activities and submit it for formal consultation. A draft Biological Assessment was written by NSTec personnel and submitted to NNSA/NSO on September 25. It was reviewed by NNSA/NSO, changes were made, and a final Biological Assessment was submitted to NNSA/NSO on November 2, 2006. This will be submitted to FWS for formal consultation by NNSA/NSO. 
THIS PAGE INTENTIONALLY LEFT BLANK 


\subsection{ECOSYSTEM MAPPING/DATA MANAGEMENT}

Ecological Services began comprehensive mapping of plant communities and wildlife habitat on the NTS in FY 1996. Data were collected describing selected biotic and abiotic habitat features within field mapping units called Ecological Landform Units (ELUs). ELUs are landforms (Peterson, 1981) with similar vegetation, soil types, slope, and hydrology. Boundaries of the ELUs were defined using aerial photographs, satellite imagery, and field confirmation. ELUs are considered by NTS biologists to be the most feasible mapping unit by which sensitive plant and animal habitats can be described. In December 2000, a topical report describing the classification of habitat types on the NTS was published and distributed (Ostler et al., 2000). Ten vegetation alliances and 20 associations were recognized as occurring on the NTS.

In 2006, efforts continued to update and improve these habitat data. Efforts focused on the following tasks in support of ecosystem mapping and data management of all NTS geospatial ecological data:

- Hard copies of EMAC annual reports and selected topical reports prior to 2003 (since 1995) were converted to electronic versions (Portable Document Format [PDF] files) to facilitate electronic document exchange, rapid retrieval, duplication, and printing

- A small number of ELUs $(<20)$ were rephotographed

- A vegetation survey was conducted to determine wildland fire hazards

- Coordination was made with ecosystem management agencies and scientists

\subsection{Conversion of Older EMAC and Selected Topical Reports to PDF Files}

A need was recognized in 2006 to secure and archive older EMAC and selected topical reports by manually scanning most reports and converting images to PDF files. It was also anticipated that these reports could be used to develop a new NTS programmatic environmental impact statement (EIS) or supplement to the current 10-year EIS which was scheduled to end in 2006.

The following reports have been converted to PDF and electronic copies provided to the DOE National Nuclear Security Administration Nevada Site Office Public Reading Facility:

- Current Distribution, Habitat, and Status of Category 2 Candidate Plant Species on and near the U.S. Department of Energy's Nevada Test Site (Blomquist et al., 1995)

- Basic Environmental Compliance and Monitoring Program Fiscal Year 1996 Progress Report (Bechtel Nevada [BN], 1996)

- Distribution of the Chuckwalla, Western Burrowing Owl, and Six Bat Species on the Nevada Test Site (Steen et al., 1997)

- Nevada Test Site Wetlands Assessment (Hansen et al., 1997)

- Distribution of Clokey's Eggvetch (Astragalus oophorus var. clokeyanus) on the Nevada Test Site (Anderson, 1998)

- $\quad$ The Relative Abundance of Desert Tortoises on the Nevada Test Site within Ecological Landform Units (Woodward et al., 1998)

- Nevada Test Site Resource Management Plan (DOE/NV, 1998)

- Ecological Monitoring and Compliance Program Reports (BN, 1997; 1998; 1999; 2000; 2001b; 2002b; 2003; 2005; 2006)

- Nevada Test Site Resource Management Plan, Annual Summary (DOE/NV, 2000) 
- Classification of Vegetation on the Nevada Test Site (Ostler et al., 2000)

- Ecology of the Nevada Test Site: An Annotated Bibliography, with Narrative Summary, Keyword Index, and Species Lists (Wills and Ostler, 2001)

- New Technologies to Reclaim Arid Lands User's Manual (Ostler et al., 2002)

- Vegetation Change Analyses User's Manual (Hansen and Ostler, 2002)

- Ecology of the Western Burrowing Owl on the Nevada Test Site (Hall et al., 2003)

- Perennial Vegetation Data from Permanent Plots on the Nevada Test Site, Nye County, Nevada (Webb et al., 2003)

- Rooting Characteristics of Vegetation Near Areas 3 and 5 Radioactive Waste Management Sites at the Nevada Test Site (Hansen and Ostler, 2003)

- A Survey of Vegetation and Wildland Fire Hazards on the Nevada Test Site (Hansen and Ostler, 2004)

\subsection{Updating Selected Photographs of ELUs}

ELUs that were sampled in 1996 did not contain information about shrub canopy cover, and photographs taken during 1996 were substandard. They were made from transparency slides and the color quality of the slide film shifted dramatically through the season and during the 5 years since they were taken. For these reasons, a need was recognized to secure additional photos and data about vegetation on ELUs sampled during 1996.

Beginning in 1999, selected ELUs have been revisited as the opportunity presents itself, often during the conduct of other EMAC field activities, to obtain better photographs and vegetation data. During 2006, about 20 ELUs were revisited to collect additional photographs and information. The new photos and data were added and linked to the existing Ecological Geographic Information System (EGIS) database. Canopy cover data were also used to update the vegetation fuels wildland fire hazard assessment for the NTS conducted in 2006.

\subsection{Vegetation Survey for Determining Wildland Fire Hazards}

Wildland fires on the NTS require considerable financial resources for fire suppression and mitigation. For example, costs for fire suppression on or near the NTS can cost as much as $\$ 198$ per ha ( $\$ 80$ per ac). Additional costs are also incurred for replacement of burned structures. For example, the Egg Point Fire in August 2002 (121 ha [300 ac]) cost well over \$1 million to replace burned power poles, while reclamation of the site cost more than $\$ 200,000$ to stabilize and revegetate.

There has been an average of 11 wildland fires per year on the NTS since 1978 with an average of about 96 ha $(23 \mathrm{ac}$ ) per fire (Table 4-1). These wildland fires do not occur randomly across the NTS, but occur more often in particular vegetation types that have sufficient fuels (woody and fine-textured fuels) which are conducive to ignition and spread of wildland fires. Once a site burns, it is much more likely to burn again because of the invasive annual plants that quickly colonize these areas unless the areas are revegetated with perennial native species.

Figure 4-1 shows the number of wildland fires on the NTS since 1978. The increase in the number of wildland fires on the NTS in 2005 and 2006 is due in large measure to the increase in winter precipitation during these years and the residual amounts of fine fuels. The distribution of NTS wildland fires by month of occurrence indicates that most wildland fires occur during the 
Table 4-1. Number and acreage of wildland fires on the NTS.

\begin{tabular}{|c|c|c|c|}
\hline Year & Fires & Acres & Hectares \\
\hline 1978 & 10 & 7,901 & 3,197 \\
\hline 1979 & 6 & 2 & 1 \\
\hline 1980 & 26 & 13,504 & 5,465 \\
\hline 1981 & 13 & 7 & 3 \\
\hline 1982 & 6 & 2 & 1 \\
\hline 1983 & 16 & 18,291 & 7,402 \\
\hline 1984 & 17 & 1,132 & 458 \\
\hline 1985 & 11 & 1,609 & 651 \\
\hline 1986 & 12 & 236 & 96 \\
\hline 1987 & 14 & 213 & 86 \\
\hline 1988 & 23 & 821 & 332 \\
\hline 1989 & 15 & 323 & 131 \\
\hline 1990 & 7 & 7 & 3 \\
\hline 1991 & 4 & 4 & 2 \\
\hline 1992 & 12 & 239 & 97 \\
\hline 1993 & 7 & 7 & 3 \\
\hline 1994 & 8 & 15 & 6 \\
\hline 1995 & 8 & 4,605 & 1,864 \\
\hline 1996 & 2 & 1,700 & 688 \\
\hline 1997 & 6 & 15 & 6 \\
\hline 1998 & 9 & 2,580 & 1,044 \\
\hline 1999 & 7 & 50 & 20 \\
\hline 2000 & 11 & 151 & 61 \\
\hline 2001 & 8 & 490 & 198 \\
\hline 2002 & 7 & 360 & 146 \\
\hline 2003 & 4 & 4 & 2 \\
\hline 2004 & 8 & 8 & 3 \\
\hline 2005 & 31 & 13,000 & 5,261 \\
\hline 2006 & 16 & 8,615 & 3,486 \\
\hline 29-Year Total & 324 & 75,891 & 30,712 \\
\hline Average Per Year & 11 & 2,617 & 1,059 \\
\hline Average Per Fire & & 238 & 96 \\
\hline
\end{tabular}


Number of Wildland Fires on the NTS by Year

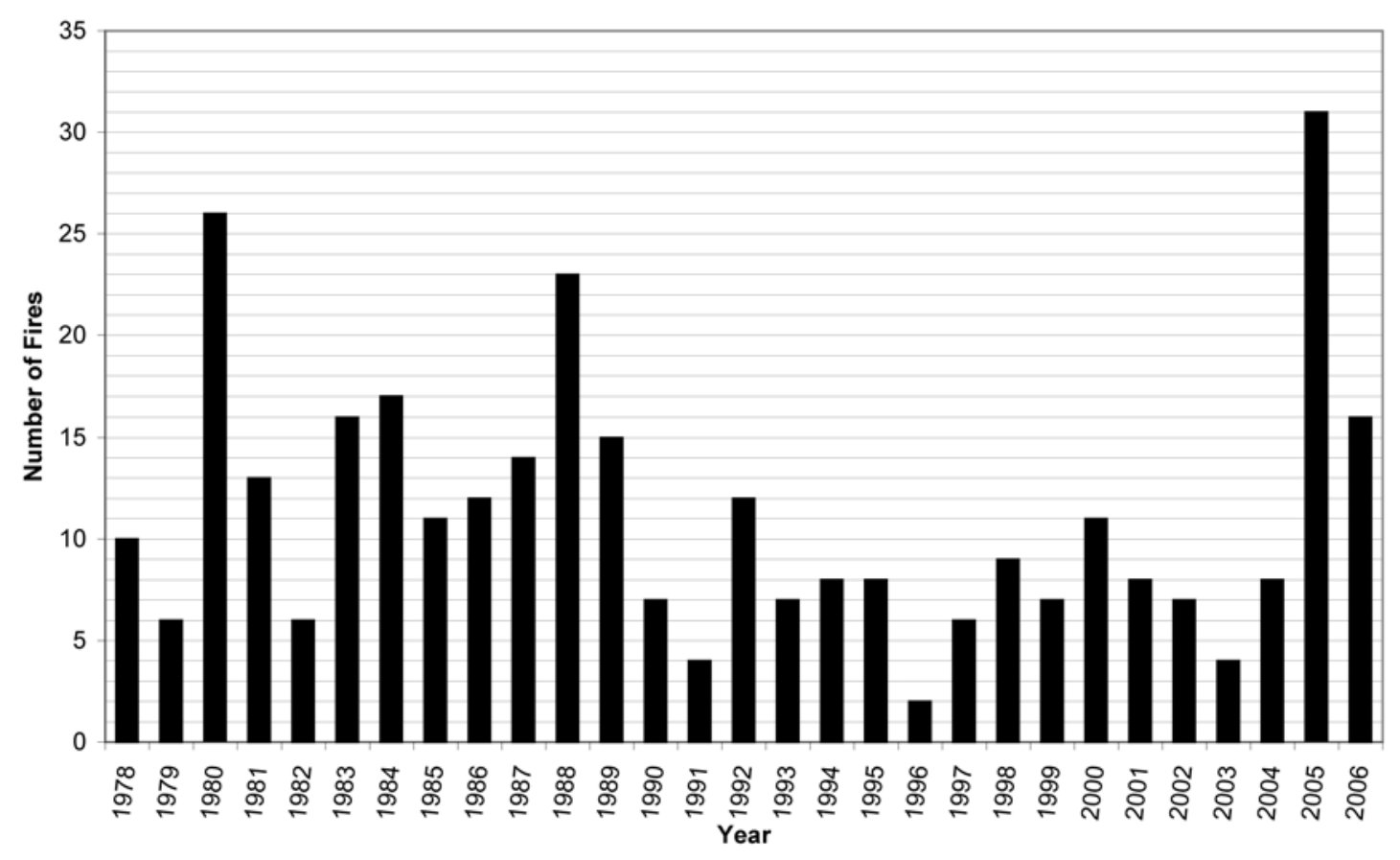

Figure 4-1. Number of wildland fires on the NTS by year.

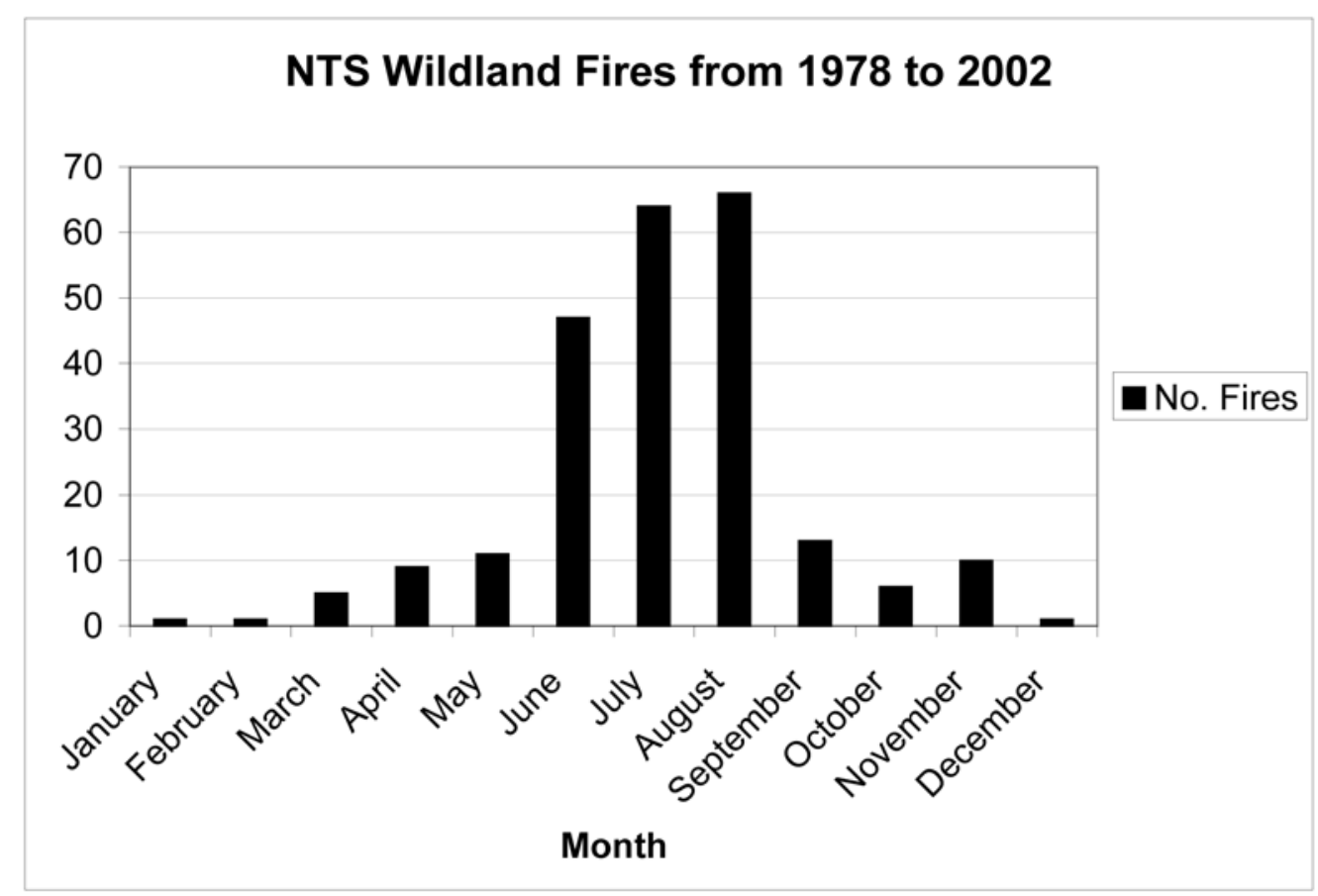

Figure 4-2. Distribution of wildland fires on the NTS by month from 1978 to 2002. 
months of June, July, and August, which also indicates the active wildland fire season on the NTS (Figure 4-2). Significantly fewer wildland fires occurred during May and September, which represent the pre- and post-season months for NTS wildland fires.

The three most commonly observed invasive annual plants to colonize burned areas are Schizmus arabicus (Arabian schismus), found at low elevations; Bromus matridensis spp. rubens, found at lower to moderate elevations; and Bromus tectorum (cheat grass), found at moderate to higher elevations (Table 4-2). Colonization by invasive species increases the likelihood of future wildland fires because they provide abundant fine fuels that are more closely spaced than native vegetation. Coleogyne ramosissima (blackbrush) vegetation types appear to be the most vulnerable plant communities to fire followed by pinyon-juniper/sagebrush vegetation types. Wildland fires are costly to control and to mitigate once they occur. Revegetation of severely burned areas is very slow without reseeding or transplanting with native species and other rehabilitation efforts. Untreated areas become much more vulnerable to future fires once invasive species, rather than native species, colonize a burned area.

Beginning in 2004, and in response to DOE Order 450.1, "Environmental Protection Program," surveys were initiated on the NTS to identify wildland fire hazards by conducting a spring (AprilMay) road survey of vegetation adjacent to 211 sites along major NTS corridors to estimate the abundance of fuels produced by native perennial and annual species and invasive weeds. Information about climate and wildland fire-related information reported by other government agencies were also identified and summarized as part of the wildland fire hazards assessment.

Table 4-2. Precipitation history and percent presence in surveyed sites (top species contributing to fine fuels).

\begin{tabular}{|c|c|c|c|}
\hline Precipitation History & 2004 & 2005 & 2006 \\
\hline & \multicolumn{3}{|c|}{ percent above average } \\
\hline Precipitation (January - April) & 4 & 67 & 20 \\
\hline \multirow[t]{2}{*}{ Invasive Introduced Species } & 2004 & 2005 & 2006 \\
\hline & \multicolumn{3}{|c|}{ percent presence } \\
\hline Bromus matridensis spp. rubens (red brome) & 51.7 & 64.4 & 67.8 \\
\hline Bromus tectorum (cheatgrass) & 40.3 & 54.0 & 60.7 \\
\hline Erodium cicutarium (redstem stork's bill) & 5.2 & 6.2 & 24.6 \\
\hline Schismus arabicus (Arabian schismus) & 4.7 & 2.8 & 5.2 \\
\hline \multirow[t]{2}{*}{ Native Species } & 2004 & 2005 & 2006 \\
\hline & \multicolumn{3}{|c|}{ percent presence } \\
\hline Amsinkia tessellata (bristly fiddleneck) & 34.0 & 62.0 & 16.1 \\
\hline Mentzelia albicaulis (whitestem blazingstar) & 49.8 & 8.1 & 0.0 \\
\hline Chaenactis fremontii (pincushion flower) & 27.0 & 8.0 & 0.0 \\
\hline
\end{tabular}

\subsubsection{Survey Methods}

The details of the spring survey to assess wildland fire hazards on the NTS are described in a 2004 report by Hansen and Ostler (2004). In short, the abundance of fine-textured (grasses and 
herbs) and coarse-textured (woody) fuels were visually estimated on numerical scales using the following 10-point potential scale: $0,1,1.5,2,2.5,3,3.5,4,4.5$, and 5 (where 0 is barren and 5 is near maximum biomass encountered on the NTS).

Photographs of sites typifying these different scale values are found in Appendix A of the Ecological Monitoring and Compliance Program Calendar Year 2005 Report (BN, 2006). Additionally, the numerical abundance rating for fine fuels at a site was added to the numerical abundance rating of woody fuels to derive a combined fuels rating for each site that ranged from 0 to 10 in one-half integer increments. The index ratings for fuels at these survey sites were then plotted on a Geographic Information System (GIS) map and color coded for severity to indicate the hazards at various locations across the NTS.

\subsubsection{Survey Results}

Climate-There are 17 rain gauges on the NTS that are used to measure precipitation. Precipitation during the months of January, February, March, and April are most correlated with production of vegetation that produces fine fuels. The total accumulated precipitation appears to be highly correlated with biomass production during this spring period as reported by Hansen and Ostler (2003). Precipitation measurements at the 17 rain gauges show that when precipitation was averaged for all stations on the NTS, the amount received during the spring of 2006 exceeded the average precipitation by 20 percent (Table 4-3). This increase is substantially more than the 4-percent increase reported by Hansen and Ostler (2004) for this same period in 2004, but less than the 67 percent reported for 2005 .

The extended weather forecast for the United States for the summer of 2006 (June, July, and August) indicated hotter than average temperatures and about normal precipitation (Figure 4-3). The National Wildland Fire Outlook for the months of June through September 2006 is shown in Figure 4-4. It identified southern Nevada as having "Normal" Fire Potential for the projected period of June 1 to September 30, 2006.

Fuels - Because of the 20-percent increase in precipitation, corresponding increases in fine fuels were observed (Figure 4-5). Increases in woody fuels were not as dramatic (Figure 4-6) as increases in fine fuels. Based on a comparison of ground photographs from 2005 to 2006, shrubs added additional foliar density and height, but not a substantial observable increase in biomass, therefore the woody fuels index did not increase appreciably. Figure 4-7 shows the combined index values for fine fuels and woody fuels. Highest index values were reported for Fortymile Canyon, Pahute Mesa, and moderate slopes around Yucca Flat.

The average combined index values by NTS operational area are shown in Table 4-4. The NTS average combined index value for fine fuels and woody fuels for 2006 was 5.26 compared to 5.64 in 2005 (a very wet year) and 4.88 in 2004 (an average precipitation year). NTS areas having the highest combined fuels average index values were Areas 29 (8.3), 30 (6.72), 12 (6.67), 8 (6.50), 16 (6.43), 10 (6.17), and 14 (6.00).

Examples of the observable differences in fine fuels during the past three years are shown in Figures 4-8 and 4-9. Major fires (>100 acres) on the NTS in 2006, 2005, and previous years are shown in the Figure 4-10. 
Table 4-3. Inches of precipitation for meteorological recording stations on the NTS for January through April 2006 compared to long-term averages.

\begin{tabular}{|c|c|c|c|c|c|c|}
\hline & & & hes of 1 & ecipitat & & Percent of AVG** \\
\hline & YEAR & JAN & FEB & MAR & APR & January - April \\
\hline & 2006 & 0.890 & 1.270 & 3.170 & 1.270 & \\
\hline RAINIER MESA (A12) & LongTerm AVG* & 1.610 & 1.690 & 1.920 & 0.880 & \\
\hline & Percent of AVG ${ }^{\star *}$ & 55.3 & 75.1 & 165.1 & 144.3 & 110 \\
\hline & 2006 & 0.450 & 0.520 & 0.910 & 0.650 & \\
\hline BUSTER JANGLE (BJY) & LongTerm AVG* & 0.830 & 0.970 & 0.750 & 0.380 & \\
\hline & Percent of $A V G^{\star *}$ & 54.2 & 53.6 & 121.3 & 171.1 & 100 \\
\hline & 2006 & 0.410 & 1.230 & 1.790 & 0.550 & \\
\hline CANE SPRINGS (CS) & LongTerm AVG* & 1.160 & 1.400 & 0.970 & 0.480 & \\
\hline & Percent of AVG ${ }^{\star \star}$ & 35.3 & 87.9 & 184.5 & 114.6 & 106 \\
\hline & 2006 & 0.480 & 0.900 & 1.880 & 0.700 & \\
\hline DESERT ROCK (DRA) & LongTerm AVG* & 0.680 & 0.920 & 0.680 & 0.350 & \\
\hline & Percent of AVG ${ }^{\star \star}$ & 70.6 & 97.8 & 276.5 & 200.0 & 161 \\
\hline & 2006 & 0.250 & 0.540 & 1.060 & 0.330 & \\
\hline AREA 06 (SOUTH) & LongTerm AVG* & 0.510 & 1.470 & 0.450 & 0.570 & \\
\hline & Percent of AVG ${ }^{\star *}$ & 49.0 & 36.7 & 235.6 & 57.9 & 95 \\
\hline & 2006 & 0.270 & 0.690 & 1.930 & 0.830 & \\
\hline JACKASS FLATS (4JA) & LongTerm AVG* & 0.710 & 1.040 & 0.750 & 0.330 & \\
\hline & Percent of AVG ${ }^{\star \star}$ & 38.0 & 66.3 & 257.3 & 251.5 & 153 \\
\hline & 2006 & 0.890 & 1.350 & 3.450 & 1.060 & \\
\hline E TUNNEL (ETU) & LongTerm AVG* & 1.210 & 2.780 & 1.150 & 1.040 & \\
\hline & Percent of AVG ${ }^{\star \star}$ & 73.6 & 48.6 & 300.0 & 101.9 & 131 \\
\hline & 2006 & 0.580 & 1.120 & 1.690 & 0.970 & \\
\hline LITTLE FELLER 2 (LF2) & LongTerm AVG* & 1.030 & 1.200 & 1.230 & 0.550 & \\
\hline & Percent of AVG ${ }^{\star *}$ & 56.3 & 93.3 & 137.4 & 176.4 & 116 \\
\hline & 2006 & 0.330 & 0.750 & 1.410 & 0.470 & \\
\hline MERCURY (MER) & LongTerm AVG* & 0.710 & 0.870 & 0.670 & 0.320 & \\
\hline & Percent of AVG ${ }^{\star \star}$ & 46.5 & 86.2 & 210.4 & 146.9 & 123 \\
\hline & 2006 & 0.720 & 1.130 & 1.940 & 0.590 & \\
\hline MID VALLEY (MV) & LongTerm AVG* & 1.390 & 1.670 & 1.110 & 0.510 & \\
\hline & Percent of AVG ${ }^{\star *}$ & 51.8 & 67.7 & 174.8 & 115.7 & 102 \\
\hline & 2006 & 0.470 & 0.920 & 1.960 & 1.090 & \\
\hline 40 MILE CANYON NORTH (40M) & LongTerm AVG* & 0.860 & 1.140 & 1.020 & 0.530 & \\
\hline & Percent of AVG ${ }^{\star \star}$ & 54.7 & 80.7 & 192.2 & 205.7 & 133 \\
\hline & 2006 & 0.450 & 0.720 & 2.100 & 1.290 & \\
\hline PAHUTE MESA 1 (PM1) & LongTerm AVG* & 0.640 & 0.830 & 0.880 & 0.640 & \\
\hline & Percent of AVG ${ }^{\star \star}$ & 70.3 & 86.7 & 238.6 & 201.6 & 149 \\
\hline & 2006 & 0.480 & 0.640 & 1.670 & 1.300 & \\
\hline PHS FARM (PHS) & LongTerm AVG* & 0.950 & 1.220 & 0.980 & 0.510 & \\
\hline & Percent of AVG ${ }^{\star \star}$ & 50.5 & 52.5 & 170.4 & 254.9 & 132 \\
\hline & 2006 & 0.270 & 0.970 & 1.620 & 0.500 & \\
\hline ROCK VALLEY (RV) & LongTerm AVG* & 0.840 & 1.170 & 0.870 & 0.340 & \\
\hline & Percent of AVG ${ }^{\star \star}$ & 32.1 & 82.9 & 186.2 & 147.1 & 112 \\
\hline & 2006 & 0.710 & 0.900 & 2.220 & 0.630 & \\
\hline TIPPIPAH SPRINGS (TS2) & LongTerm AVG* & 1.100 & 1.450 & 1.070 & 0.520 & \\
\hline & Percent of $A V G^{\star \star}$ & 64.5 & 62.1 & 207.5 & 121.2 & 114 \\
\hline & 2006 & 0.280 & 0.640 & 1.180 & 0.370 & \\
\hline WELL 5 B (W5B) & LongTerm AVG* & 0.600 & 0.710 & 0.550 & 0.350 & \\
\hline & Percent of AVG** & 46.7 & 90.1 & 214.5 & 105.7 & 114 \\
\hline & 2006 & 0.480 & 0.590 & 1.100 & 0.300 & \\
\hline YUCCA DRY LAKE (UCC) & LongTerm AVG* & 0.950 & 1.040 & 0.750 & 0.370 & \\
\hline & Percent of AVG ${ }^{\star *}$ & 50.5 & 56.7 & 146.7 & 81.1 & 84 \\
\hline & Percent of $A$ & ige $\mathrm{Pr}$ & oitatic & All & tions ${ }^{\star *}$ & 120 \\
\hline $\begin{array}{l}{ }^{*} \text { Long-term average precipitatio } \\
{ }^{*} \text { A value of } 100 \text { means precipit } \\
\text { A value of } 120 \text { means precipita } \\
\text { A value of } 80 \text { means that preci }\end{array}$ & $\begin{array}{l}\text { inches for the month } \\
n \text { equaled the mean of } \\
\text { exceed the mean by } \\
\text { tion was less than the }\end{array}$ & $\begin{array}{l}\text { e long-te } \\
\% \\
\text { ean by } 2\end{array}$ & n avera & for all s & tions for & nuary thru April \\
\hline
\end{tabular}



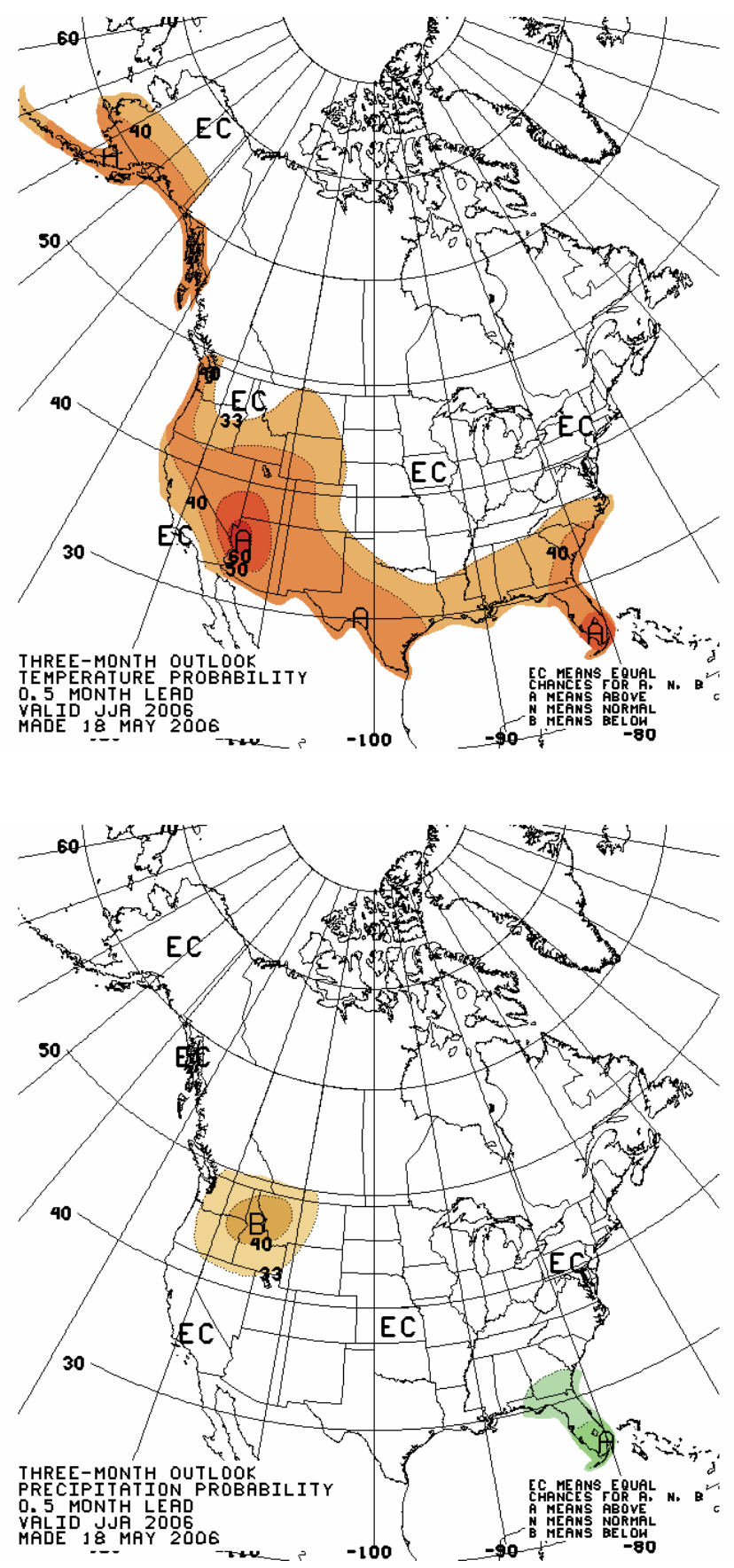

Figure 4-3. Extended weather forecast for June, July, and August of 2006 for temperature and precipitation. (Source of long-range forecasts as of May 18, 2006: http://www.cpc.ncep.noaa.gov/products/predictions/ multi_season/13_seasonal_outlooks/color/churchill.html). 


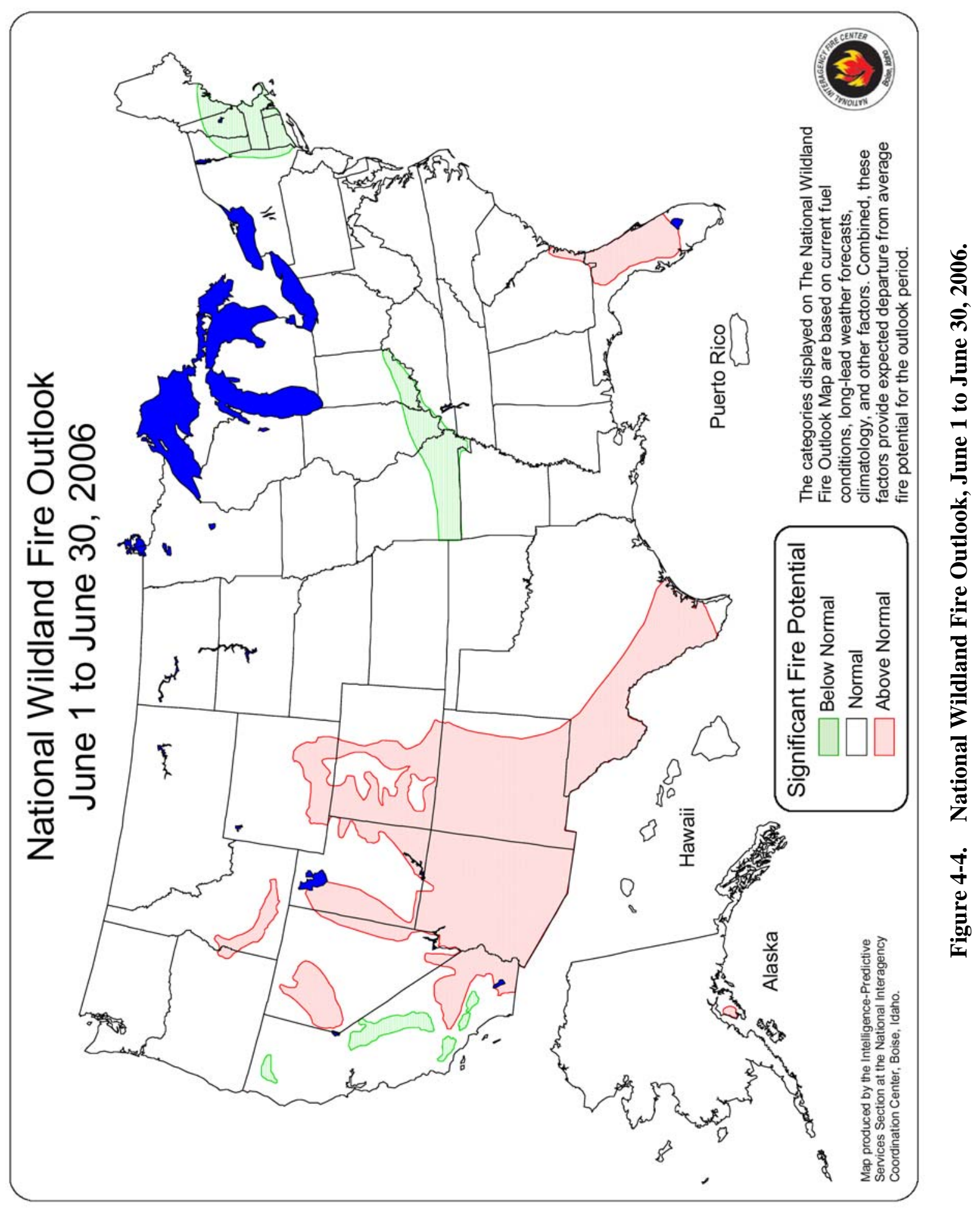




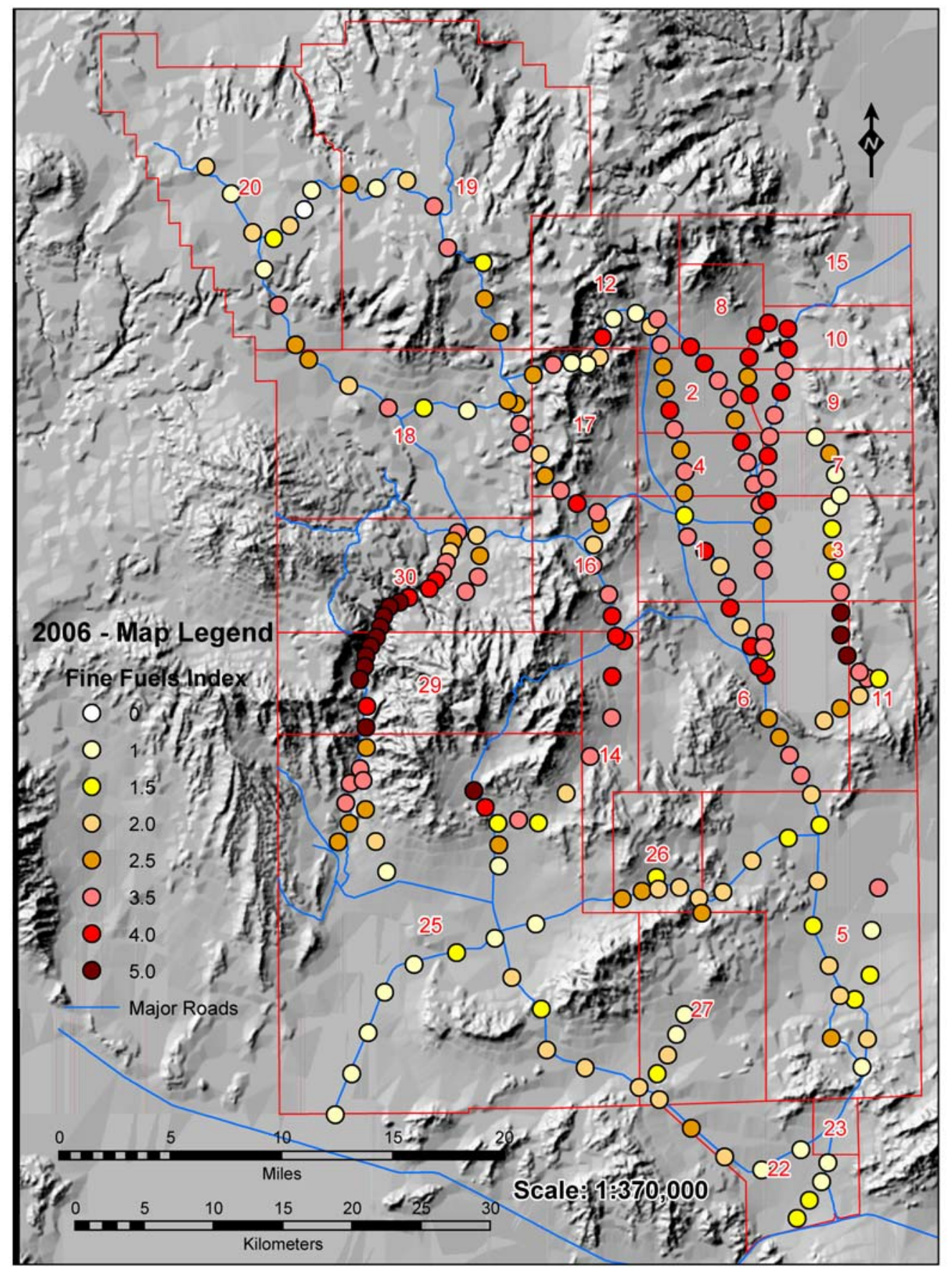

Figure 4-5. Index of fine fuels for 211 survey stations on the NTS by operational area during 2006. 


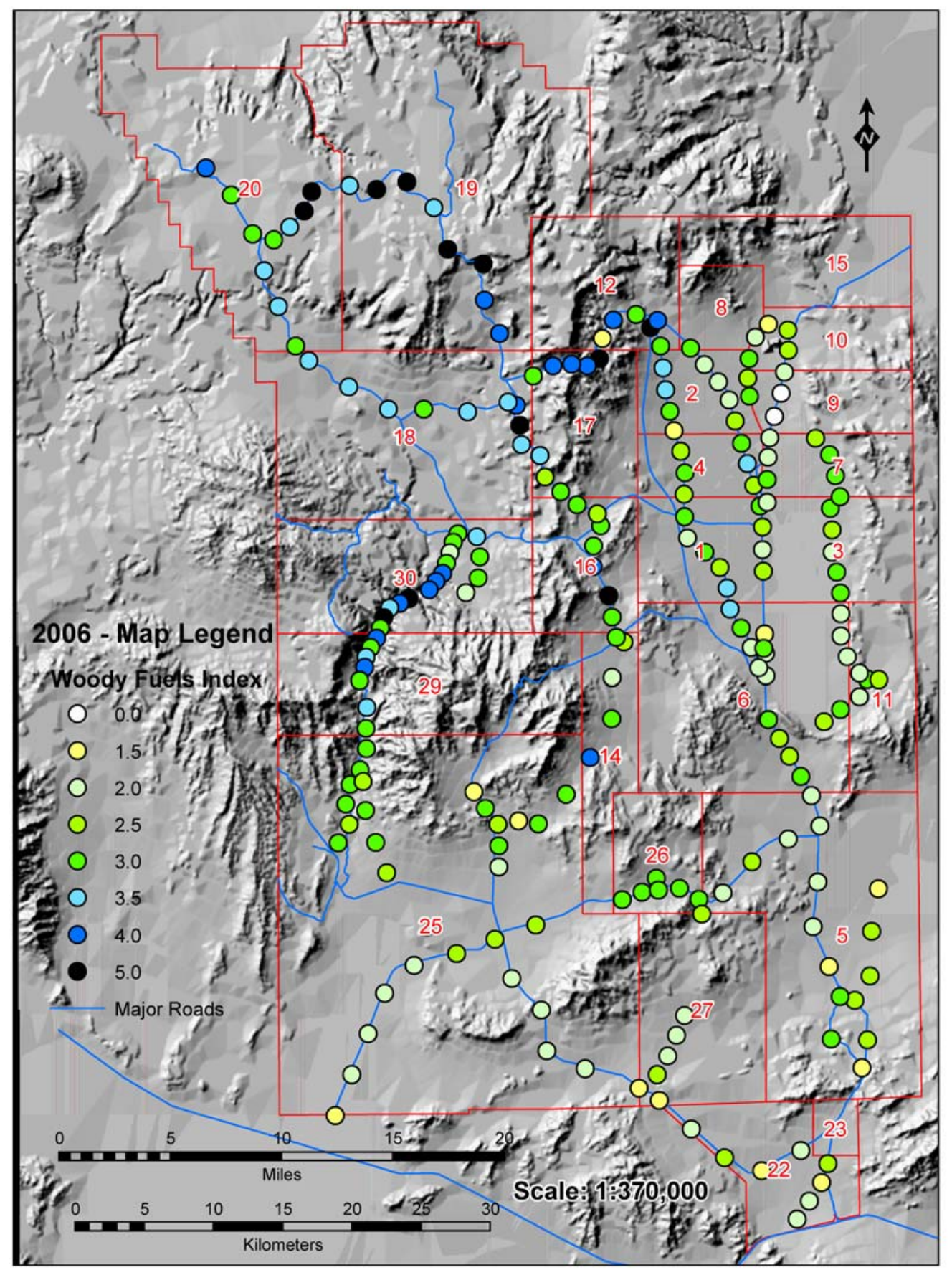

Figure 4-6. Index of woody fuels for 211 survey stations on the NTS by operational area during 2006. 


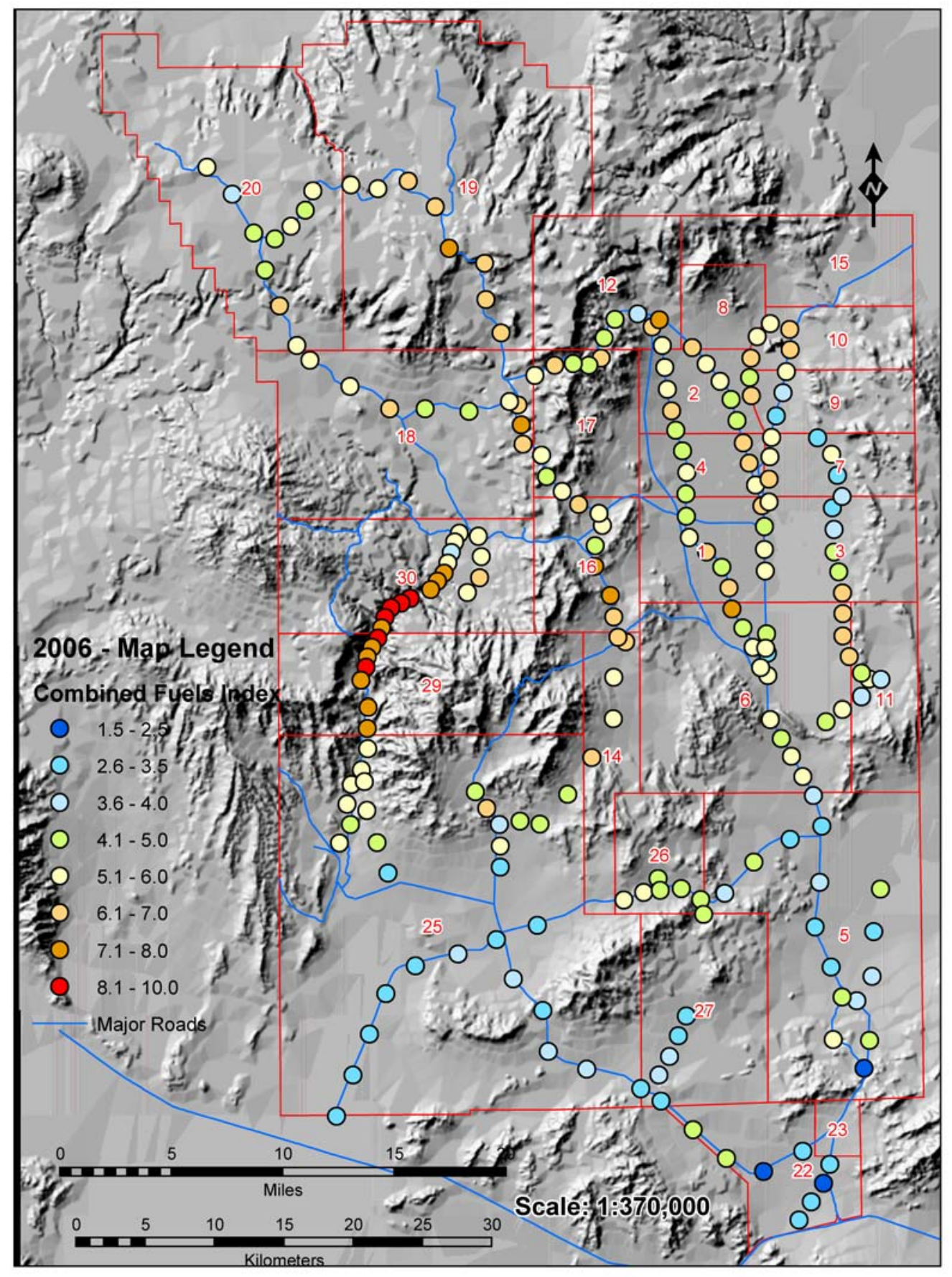

Figure 4.7. Index of combined fine fuels and woody fuels for 211 survey stations on the NTS by operational area during 2006. 
Table 4-4. Comparison of combined fuel ratings on the NTS for 2004, 2005, and 2006.

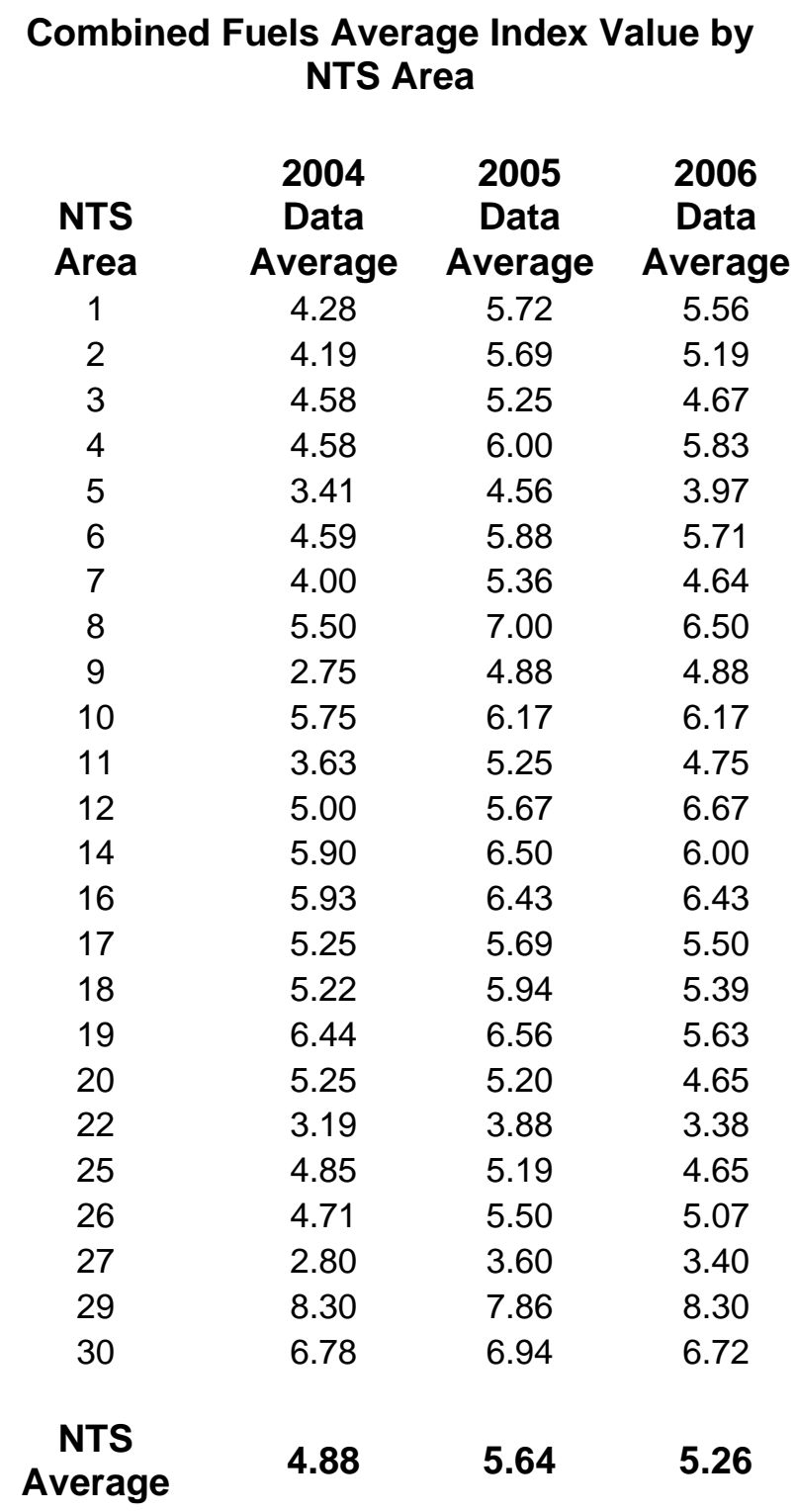



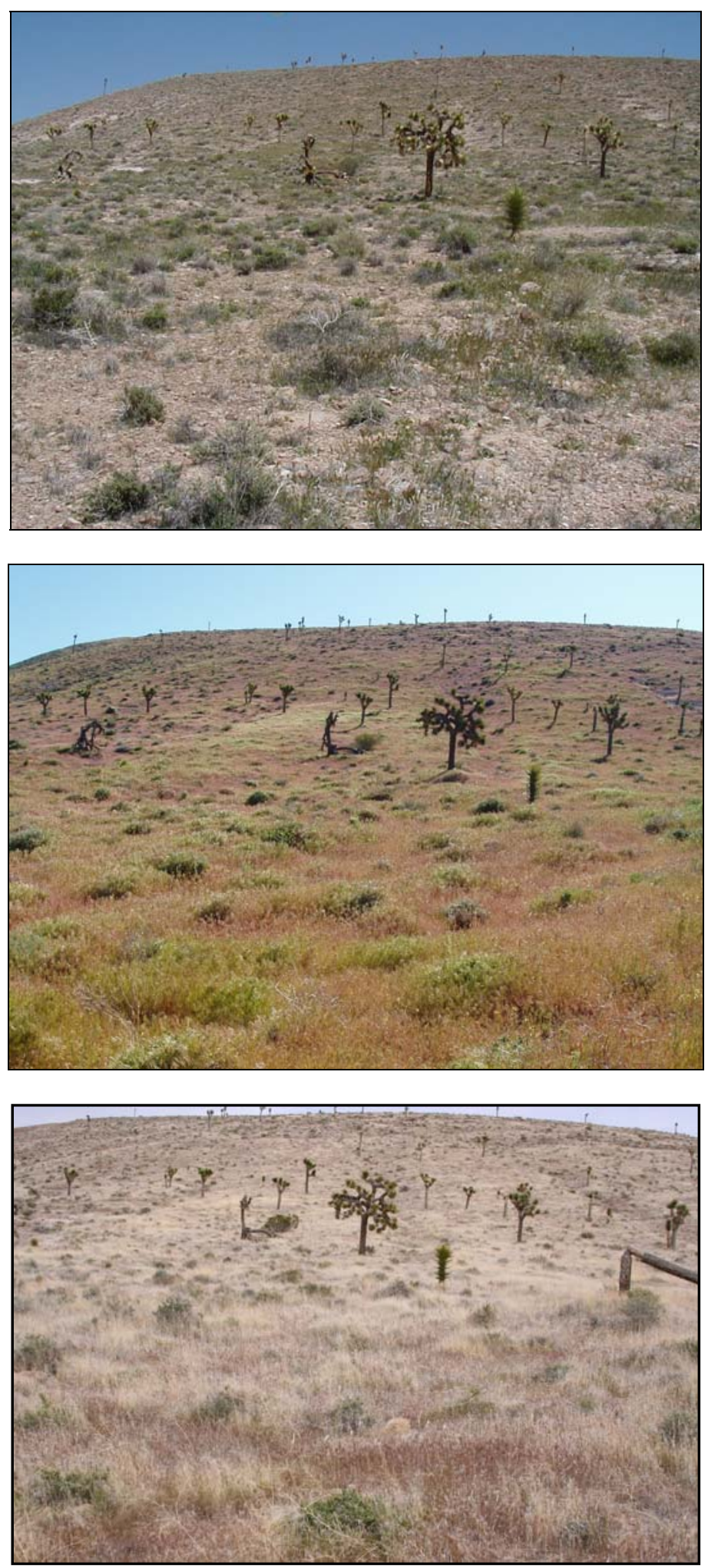

Figure 4-8. Site 83 on the east side of Yucca Flat in 2004-2006. (Photos by W. K. Ostler, April 26, 2004 [top], April 20, 2005 [middle], and April 26, 2006 [bottom]) 

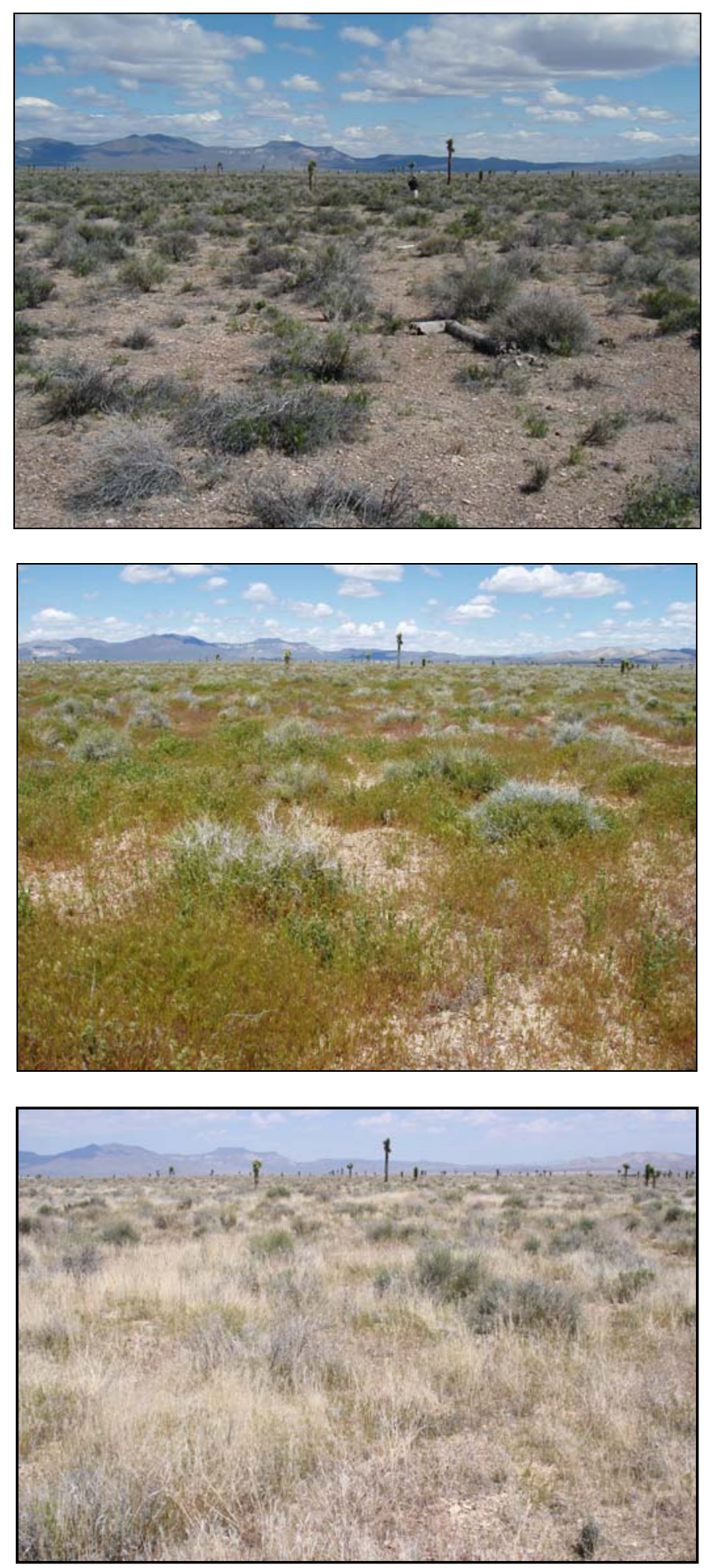

Figure 4-9. Site 99 on the west side of Yucca Flat in 2004-2006. (Photos by W. K. Ostler, April 29, 2004 [top], April 20, 2005 [middle], and May 4, 2006 [bottom]) 


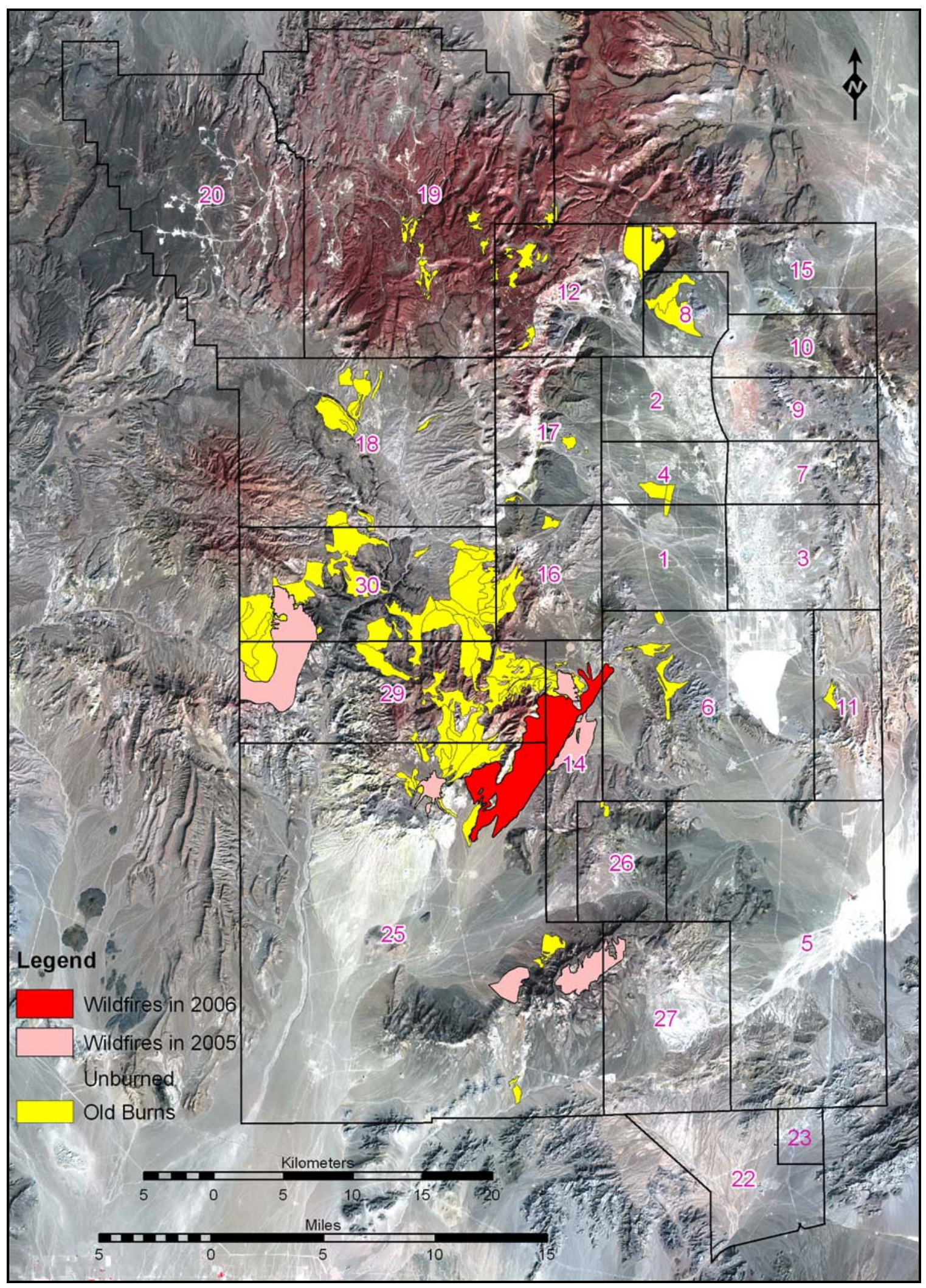

Figure 4-10. Location of wildland fires on the NTS. 


\subsection{Coordination with Scientists and Ecosystem Management Agencies}

NSTec biologists interfaced with other scientists and ecosystem management agencies in 2006 for the following activities:

- Participated in two planning meetings to discuss revegetation with Bureau of Land Management, FWS, Nevada Division of Wildlife, and USGS personnel assessing impacts of the large wildfires in southern Nevada and developing emergency stabilization plans for controlling erosion from these sites. Provided presentations on revegetation in the Mojave Desert including techniques, species selection, timing, and irrigation. Meetings were held in April and May of 2006 in Las Vegas, Nevada.

- Made two presentations at the $14^{\text {th }}$ Annual Wildland Shrub Symposium on June 6-8, 2006, at Cedar City, Utah and prepared a written paper for inclusion in the proceedings. The theme of the symposium was: Shrublands Under Fire--Disturbance and Recovery in a Changing World. 
THIS PAGE IS INTENTIONALLY LEFT BLANK 


\subsection{SENSITIVE PLANT MONITORING}

There are 20 plant species which occur on the NTS that are considered sensitive and are listed by NNHP as rare plants. The goal of monitoring sensitive species is to ensure the continued presence of all sensitive plants on the NTS by protecting them from significant impacts due to NNSA/NSO actions. A secondary goal is to maintain an information database on these species' distribution and abundance on the NTS. This information is used to evaluate their status periodically and determine whether additional protection or management under state or federal law is necessary, or if the species should still be included on the NNHP list of rare plant species.

With the passage of ESA in 1973 and its amendment in 1978, an effort began to first identify and then to protect those plants considered rare or whose existence might be threatened or endangered from ongoing or proposed ground-disturbing activities. NNSA/NSO supported the identification of rare plants known to occur on the NTS that might warrant protection under the provisions of the ESA. After numerous literature and herbarium searches, local scientists recommended the listing of 12 species as potentially endangered and another 15 as threatened (Beatley, 1977a; Beatley, 1977b). Field surveys for these species followed (Rhoads and Williams, 1977; Rhoades et al,. 1978) and, within a couple years, the list of potentially endangered or threatened plants on the NTS included five potentially endangered plants and nine threatened plants (Rhoades et al., 1979). Ten of the original 27 endangered or threatened plants were considered rare but did not warrant protection of the ESA. Three other species were found to be more widely distributed than originally documented and were not given any status. Four plants were listed by the State of Nevada Division of Forestry in 1979 as critically endangered, but all four have since been delisted: two in 1982, one in 1983, and one in 2001. By 1980, when a state-wide list of potentially endangered and threatened plants was published (Mozingo and Williams, 1980), 3 of the original 27 plants listed for the NTS were included as potentially endangered, 7 as threatened, and 16 were "not considered to be immediately threatened or endangered, but ... need to be monitored" and were categorized as species to "watch." One of the original 27 plants was not included on this list and was essentially delisted. At the same time, three plant species that occur on the NTS were added to the original list of endangered and threatened plants.

Over the next several years, field surveys were conducted and status reports prepared for many of the 29 plant species listed by Mozingo and Williams (1980) and known to occur on or near the NTS as well as other plants that were recognized as potential candidates as endangered or threatened plants. FWS ultimately recognized 10 of the original listing of endangered and threatened plants as candidates for protection under the ESA, as well as 2 other plants considered rare and known to occur on the NTS. These 12 plants were the focus of field surveys during the early 1990s (Blomquist et al., 1992; Blomquist et al., 1995) and efforts focused on obtaining sufficient information for FWS to make a final determination as to whether the species warranted protection under the ESA. Blomquist et al. (1995) found that all 12 of the species were more abundant than originally determined and no identifiable threats were observed during the surveys. In addition there were taxonomic issues with two of the species which further suggested that none of the 12 species warranted protection under the provisions of the ESA.

Currently, there are no plant s species known to occur on the NTS that have been listed as endangered or threatened under the provisions of the ESA, nor are there any being considered for listing. The state of Nevada has not listed any plants as Critically Endangered for the NTS. One plant was being considered at one point, but after extensive studies it was determined that it did not warrant listing. NNHP maintains a list of at-risk plants for the state of Nevada, which includes 19 vascular plants and one nonvascular plant, that occur on or adjacent to the NTS. 
Thirteen of the 20 plants were originally proposed as endangered or threatened by Beatley (Beatley, 1977a; Beatley, 1977b) and Rhoades (Rhoades et al., 1979) in the late 1970s. One plant was added by Mozingo and Williams (1980). The type localities for six of the plants are found on the NTS and nine plants are endemic to Nevada. The latest addition to the list is a new plant species described in 2002 (Atwood et al., 2002) which occurs in Rock Valley and the Frenchman Flat areas of the NTS.

Management of at risk or rare plants on the NTS has changed over the years. In the 1970s and 1980s, the emphasis was on field inventories to determine the presence of such species on the NTS and also determine if NNSA/NSO activities were impacting any of them. Following those activities, DOE/NV prepared a Resource Management Plan (RMP) which included objectives to protect and conserve sensitive plant species found on the NTS and to minimize cumulative impacts to those species as a result of NNSA/NSO activities (DOE/NV, 1998). Pursuant to that document, BN published and distributed an Adaptive Management Plan for Sensitive Plant Species on the Nevada Test Site (BN, 2001a). This document presents the procedures designed to ensure that the RMP goals are met by identifying parameters to be measured during long-term monitoring and outlining management actions that may be taken if significant threats to sensitive species are detected. Monitoring activities this year included a review of species on the list of sensitive plant species for the NTS after coordination with other agencies and professionals, and monitoring five sensitive plant species found on the NTS.

\subsection{List of Sensitive Plant Species for the NTS}

The list of sensitive plant species for the NTS was reviewed in 2006. Two species were added to the list and one species was deleted, making a total of 19 vascular plant species and 1 nonvascular plant species included on the list of sensitive plants (see Table 2-1, shown previously) for the NTS. In the Adaptive Management Plan (BN, 2001), it is recommended that plant species found on the NTS that may require protection because of such factors as rarity, susceptibility to disturbance, or ecological or economic importance, be identified. Other agencies are consulted in determining which species should be protected. Under NNHP, the Nevada Department of Conservation and Natural Resources maintains a detailed list of rare vascular and nonvascular plants, which includes plants protected by federal agencies, the Division of Forestry of the state of Nevada, and the Nevada Native Plant Society (NNPS). NNHP along with NNPS sponsors a Rare Plant Workshop annually. In 2006 it was held in Reno, on April 6. Participants included state and federal agency representatives, academia, land resource managers, and private concerns. The workshop provides an opportunity for participants to coordinate their efforts in protecting rare plant species and to make recommendations regarding the protection of species under state or federal laws and regulations.

During 2006's workshop several significant actions were taken affecting the list of sensitive plant species for the NTS. The taxonomy for two species that occur on the NTS has been an issue for several years (Mozingo and Williams, 1980; Blomquist et al., 1995). Frasera pahutensis (Pahute green gentian), a Nevada endemic, is treated in the PLANTS database (U.S. Department of Agriculture [USDA], 2006) as synonymous with Frasera albicaulis var. modocensis (Modoc frasera). This was a topic of discussion at the annual rare plant workshop in 2000 and again in 2006. The workshop chair commented that "Frasera pahutensis - has been synonymized with Frasera albicaulis var. modocensis of northeastern California in the current North American checklist. Participants who knew the two taxa considered them quite different, and thought the synonymy ridiculous. No one was aware of any published or unpublished support for such 
synonymy, which appears to be without merit. CONSENSUS: without objection, the group recognizes F. pahutensis as a valid taxon" (minutes of 2000 Nevada Rare Plant Workshop, http://heritage.nv.gov/workshop.htm).

There is a similar issue with Cymopterus ripleyi var. saniculoides (Sanicle biscuitroot), which for some (USDA, 2006; Hickman, 1993) is synonymous with C. ripleyi var. ripleyi (Ripley biscuitroot). It is the position of the NNHP (Notes 2006 Nevada Rare Plant Workshop, http://heritage.nv.gov/workshop.htm) that "The data we have on Cymopterus ripleyi continues to indicate that populations of var. ripleyi are concentrated in northern Nye County and/or at higher elevations, while those of var. saniculoides are concentrated in central Nye County and/or at lower elevations. And there are certainly some areas and even populations where the two forms overlap. If the color forms of Cymopterus ripleyi could be shown to occur mixed in the majority of populations of the species, then the Nevada Natural Heritage Program could certainly be convinced to discontinue recognizing the two varieties. Otherwise, we tend to take the conservative road, and assume that such forms are genetically significant to the species for conservation purposes, until it can be shown otherwise."

Several bryophytes were considered for protection during the 2005 Rare Plant Workshop (http://heritage.nv.gov/workshop.htm). One of the species, Entosthodon planoconvexus (Planoconvex entosthodon), a bryophyte previously reported from the NTS in the Rock Valley area, was recommended for listing as threatened on the NNHP Rare Plant List. In late 2005 and again in 2006 bryophyte collections were made from the Rock Valley area where it had reportedly been collected in 1984. Specimens from a particular collection site were sent to bryophyte taxonomists at the University of Nevada at Las Vegas where they were positively identified as E. planoconvexus, thus re-confirming the presence of this species on the NTS.

One plant was removed from the list of sensitive plant species for the NTS. Sclerocactus polyancistrus (redspined fishhook cactus) was added to the NNHP list of rare plants a few years ago. It was the general consensus during the 2006 Rare Plant workshop that this species is widespread throughout several western states and that it should be removed from the watch list of rare plant taxa (minutes of 2006 Nevada Rare Plant Workshop, http://heritage.nv.gov/workshop.htm).

Two species were added to the list of sensitive plant species for the NTS. Penstemon fruticiformis ssp. amargosae (Death Valley beardtongue) was included in previous rare plant studies (Blomquist et al., 1995) and was reported near the southern boundary of the NTS in the Specter mountain range. This species, like Lathyrus hitchcockianus (Bullfrog Hills peavine), has been added to the list because similar habitat does occur on the NTS. Inclusion of these species on the sensitive species list for the NTS creates awareness so their presence might be recognized during other monitoring activities on the NTS. P. fruticiformis var. amargosae is listed as threatened on the NNHP list of rare plant species.

The other plant species added to the sensitive plant species for the NTS this year is Phacelia filiae (Clarke phacelia), a new species of Phacelia recently described from specimens collected on the NTS and Tonopah Test Range (TTR) (Atwood et al., 2002). P. filiae occurs in the Frenchman flat and Rock Valley areas of the NTS as well as various locations in Nye, Lincoln and Clark Counties, Nevada. 


\subsection{Long-term Monitoring}

As described in the Adaptive Management Plan (BN, 2001a) for sensitive plants on the NTS, the goal of long-term monitoring is to maintain an accurate assessment of the distribution of sensitive plant species on the NTS and to periodically evaluate their status. In an effort to maximize monitoring efforts, the 20 sensitive plant species on the NTS have been assigned different categories based on the rarity or potential impacts. The abundance of most of the sensitive plants can vary significantly from year to year especially for annual species and even some perennials. Annual precipitation patterns and extended periods of drought have the most significant effects on overall plant abundance. The distribution of most species is well understood because of previous efforts, yet several new populations of some of the sensitive plants species have been found in the last decade. Previously, species were categorized as "actively monitored," "not monitored," and to be "evaluated" (BN, 2005). This approach has been somewhat misleading because all species are being monitored. There are some species that, either due to limited distribution or the fact they occur in areas prone to disturbance, need to be monitored more frequently. Other species are found in remote areas of the NTS distant from NNSA/NSO activities, yet their status is still monitored, albeit less frequently. Sensitive plants have therefore been grouped into three groups: those that are monitored at least once every 5 years, those that are monitored less frequently but a minimum of once in a 10-year period, and those whose status is unknown and are being evaluated.

Currently, 9 of the 20 sensitive plant species on the NTS (see Table 2-1, shown previously) are monitored once during a 5-year period. The remaining 11 species are monitored once during a 10 -year period. No species are being evaluated at present. Those species to be monitored in a given year are selected at the beginning of the year. The selection is largely based on current year growing conditions (precipitation and temperature), although susceptibility to impacts and other such criteria are also considered. Monitoring may not occur some years because of poor growing conditions, but during other years monitoring may occur for several sensitive plants.

During field monitoring the status of each population is assessed, which may include estimates or observations of plant density, plant vigor, herbivory, disease, or documentation of direct or indirect impacts to the plant or its habitat. Five species were selected for long-term monitoring in 2006. Populations of F. pahutensis and Hulsea vestita spp. inyoensis (pumice alpinegold) were inventoried and detailed delineations of the population boundaries were made (Figure 5-1). Up until last year, Ivesia arizonica var. saxosa (rock purpusia) was only known from one location on the NTS, Columbine Canyon on Pahute Mesa. Last year, another population of the species was encountered 100 meters $(\mathrm{m})(328$ feet [ft]) south of the exisiting population. This year's focus was on potential habitat for I. arizonica var. saxosa to the south and west of the two known populations (Figure 5-1).

The population of Eriogonum heermannii var. clokeyi (Clokey buckwheat) along Mercury Ridge was monitored this year with the objective of making voucher collections. Specimens of E. heermannii in the Mercury herbarium lack plant structures that are important in determining the correct variety. 


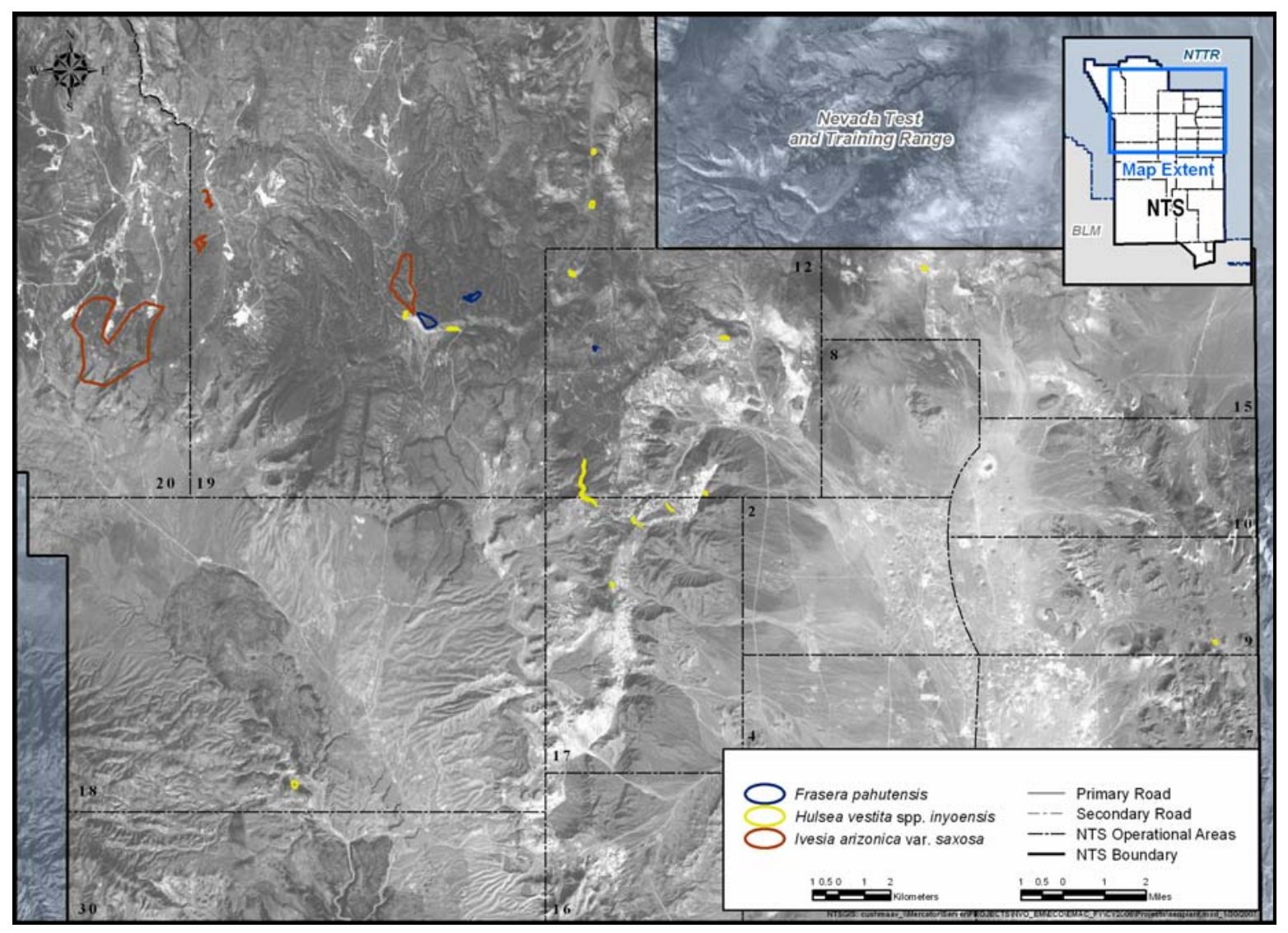

Figure 5-1. Known locations of Frasera pahutensis, Ivesia arizonica var. saxosa, and Hulsea vestita spp. inyoensis on the NTS.

The taxonomy of $C$. ripleyi var. saniculoides has been in question for several years and many collections are called C. ripleyi var. ripleyi . Field surveys this year focused on known populations of $C$. ripleyi var. ripleyi and C. ripleyi var. saniculoides to determine the correct taxonomy for each collection site.

The final species monitored this year was E. planoconvexus, a bryophyte that had been previously collected on the NTS. The objective this year was to inventory the immediate vicinity of the previous collection site to determine if similar habitat exists and if E. planoconvexus occurs there.

\subsubsection{Frasera pahutensis}

The type locality for F. pahutensis was originally described from specimens collected on Pahute Mesa in 1970 (Reveal, 1971). This species was considered by Beatley (1977a) as a potentially endangered plant species on the NTS. Rhoades et al. (1979) and Mozingo and Williams (1980) eventually recommended threatened status and the FWS considered it as a candidate for listing until authors of several status reports (Morefield, 1992; Brack, 1993; Blomquist et al., 1995) suggested that the distribution of the species was more extensive than originally known and that it did not warrant protection under the ESA. The species was later listed as a species of concern by the FWS and is currently on the NNHP watch list. 
Presently, the PLANTS Database (USDA, 2006) lists F. pahutensis in synonomy with F. albicaulis var. modocensis, which appears to be without justification (minutes of the 2000 Rare Plant Workshop, http://heritage.nv.gov/workshop.htm). In agreement with the findings of the Rare Plant Workshop participants, this species is considered a valid taxon and is included on the list of sensitive plants for the NTS and is routinely monitored.

F. pahutensis is known from two locations on the NTS: Pahute Mesa along the 19-01 Road, the type locality, and Rainier Mesa near Gold Meadows. The type locality was mapped previously by Blomquist et al. (1995). The goal of monitoring this year was to revisit the site along the 19-01 Road, define population boundaries using more accurate Geographical Positioning System (GPS) units, assess population status (density and vigor). and then transfer that information to the sensitive plant GIS database maintained by Ecological Services.

Surveys were conducted in July this year at two locations adjacent to the 19-01 Road (Figure 5-1, shown previously). At the southern most location, several hundred plants were counted along the edge of pinyon juniper woodlands transitioning into sagebrush openings (Figure 5-2).

Approximately 20 ha (49 ac) were surveyed.

Continuing to the east and north along the 19-01 Road, another previously reported location of $F$ pahutensis was surveyed. Again several hundred plants were found over about 10 ha $(24 \mathrm{ac})$. Typical habitat at this location was dense pinyon woodland with many plants found along abandoned trails used during previous activities in the area (Figure 5-3). Based on the abundance of individual plants, their vigor, and the lack of any activities in the immediate vicinity, these two populations appear to be in good condition and there appears to be no impacts from NNSA/NSO activities. There appears to be an abundance of potential habitat for this species on the NTS and additional locations may be found in the future as remote locations are accessed and surveyed. The Gold Meadows population of $F$. pahutensis will be similarly surveyed in future years.

\subsubsection{Hulsea vestita spp. inyoensis}

$H$. vestita spp. inyoensis was a proposed endangered plant species earlier (Beatley, 1977a), considered rare by Rhoades et al. (1979) and was listed as a watch species by Mozingo and Williams (1980). It has never been considered a candidate for listing by the FWS and is currently on the NNHP watch list of species for the state of Nevada. It occurs on the NTS and west into Inyo County, California. This species has not been evaluated for several years, probably since some of the original rare plant surveys in the 1970s and 1980s. Locations of $H$. vestita spp. inyoensis occur on road cuts along Holmes and Stockade Wash roads, the slopes of Rainier Mesa, north into Kawich Canyon, and east along Papoose Lake Road.

Surveys this year were completed in June. Locations of $H$. vestita spp. inyoensis previously reported along Holmes Road and Stockade Wash Road were surveyed. GPS readings were taken and information transferred into the sensitive plant GIS database. Populations surveyed this year were small and consisted of but a few plants along several road cuts. 


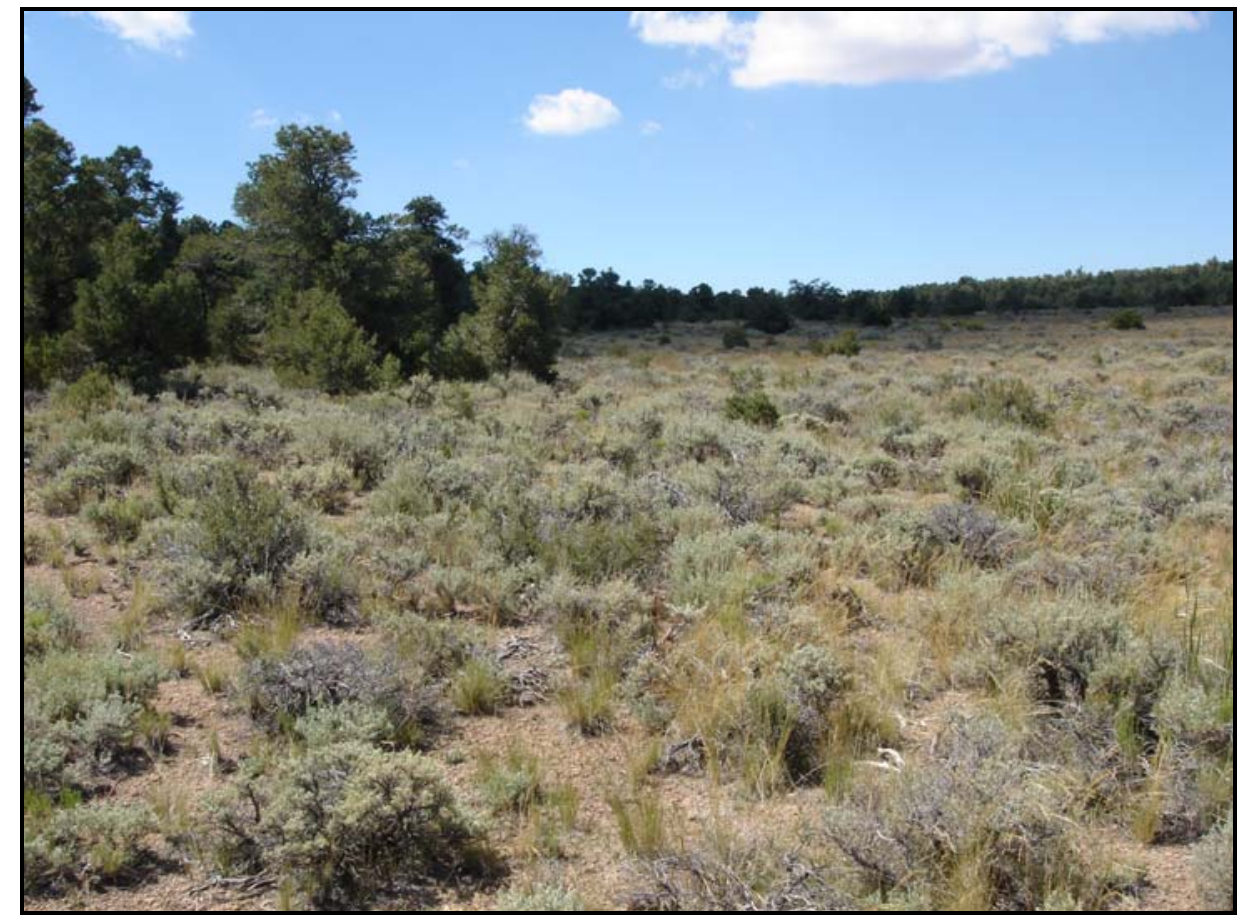

Figure 5-2. Typical habitat for F. pahutensis in transition between pinyon woodland and sagebrush shrubland on Pahute Mesa. (Photo by W. K. Ostler, July 2006)

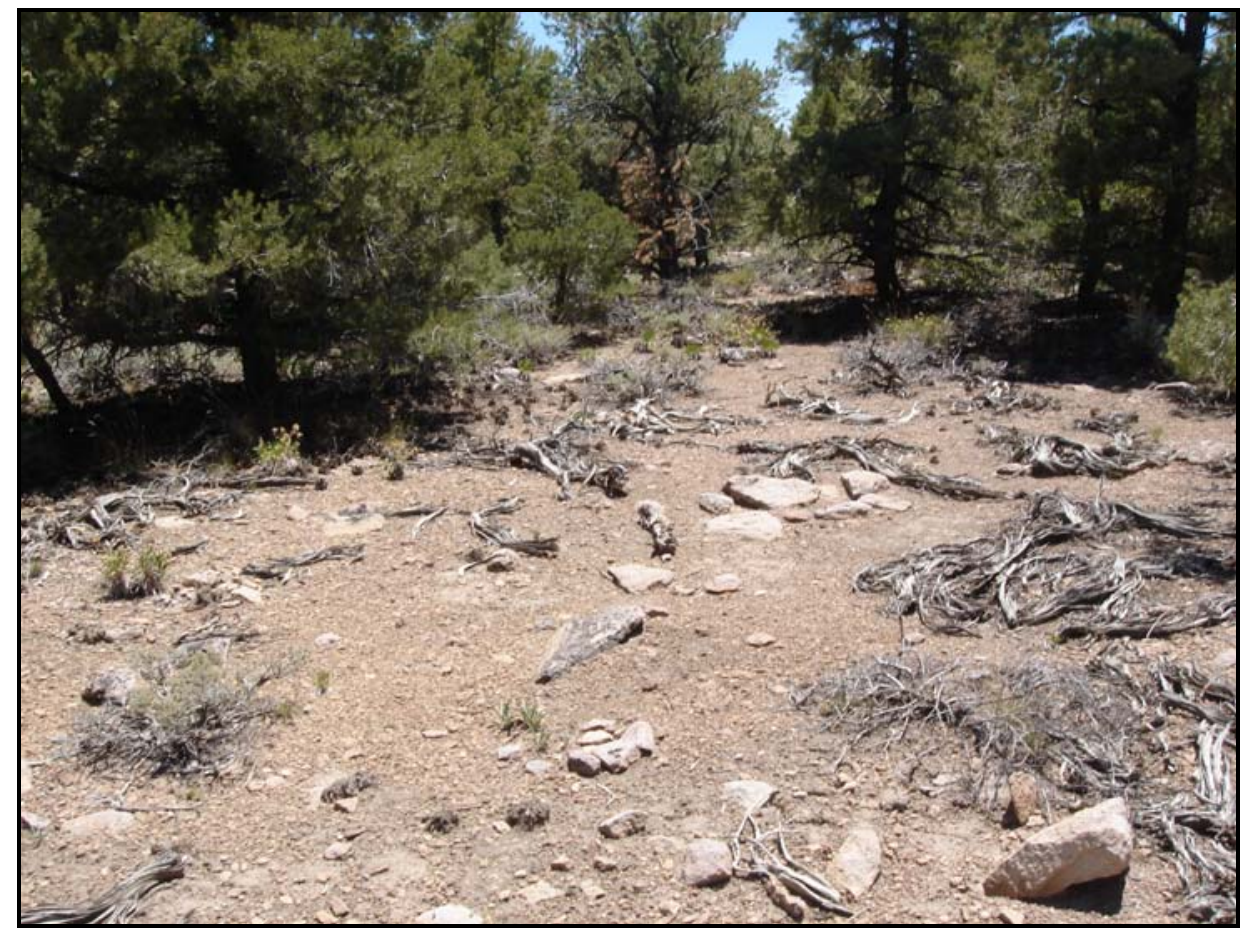

Figure 5-3. Typical habitat for $F$. pahutensis in pinyon woodland along abandoned trails. (Photo by D. C. Anderson, July 2006) 
Plants were flowering (Figure 5-4) and showed no signs of threats either from NNSA/NSO activities in the area or from natural impacts such as pests, disease, or herbivory. Future surveys for this species will focus on locations reported from the vicinity of Captain Jack Springs, north through Kawich Canyon and along Papoose Lake Road area.

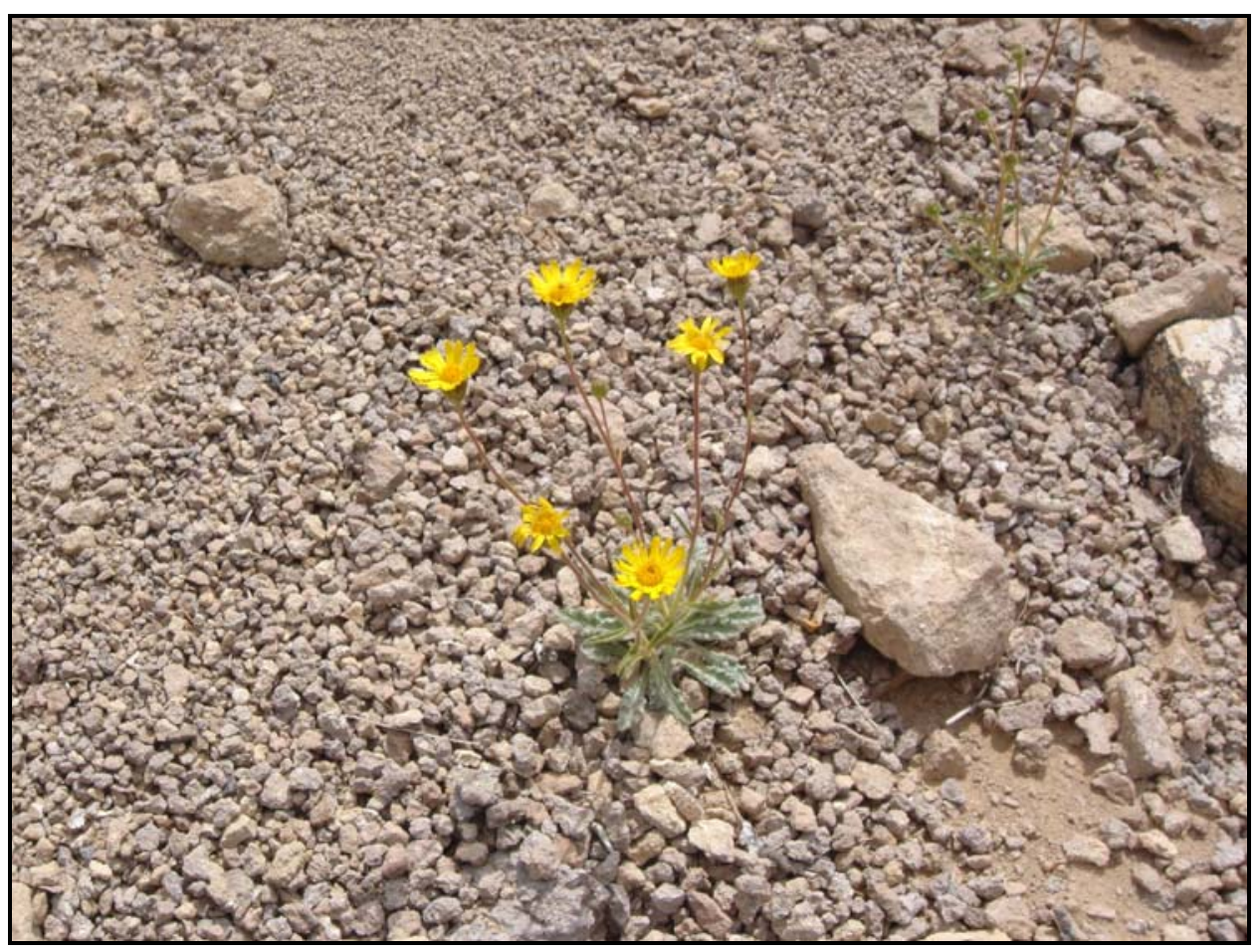

Figure 5-4. H. vestita spp. inyoensis along road cut on Holmes Road, Rainier Mesa. (Photo by D. C. Anderson, June 2006)

\subsubsection{Eriogonum heermannii var. clokeyi}

E. heermannii var. clokeyi is relatively new to the list of rare plant species for the NTS. It is currently listed as a watch species on the NNHP list of rare plants. It is known from a couple populations on the NTS as well as populations in the Spring Mountains, Sheep Mountains and some outlying locations near Hiko in Lincoln County.

Serveral specimens of E. heermannii var. clokeyi are found in the NTS herbarium, however, specimens are incomplete and lack the details required for positive identification. Surveys for this species were conducted throughout the summer with the objective of making collections for archival in the Mercury herbarium. No collections were made, however, because none of the plants set flower and any collection would not have provided the type of specimen needed for archival purposes. 


\subsubsection{Ivesia arizonica var. saxosa}

I. arizonica var. saxosa is endemic to Nevada and is one of the species that has just recently been added to the list of sensitive species on the NTS. It was not included in any of the earlier surveys by Beatley (1977a, 1977b), Rhoades et al. (1979), or Mozingo and Williams (1980). It is currently on the watch list of rare plant species maintained by the NNHP. It is endemic to Nevada and is only known from a couple locations on the NTS and in the Pahroc Mountains in Lincoln County. The only known location of I. arizonica var. saxosa on the NTS prior to 2005 was in Columbine Canyon just off of Pahute Mesa Road. In 2005, an extension of this population was located about $100 \mathrm{~m}(328 \mathrm{ft})$ to the south. Surveys continued another $300 \mathrm{~m}(984 \mathrm{ft})$ south where another small population was found. The objective of the surveys in 2006 was to first identify potential habitat using aerial photographs and topographic maps, then conduct field surveys in those areas. Several areas were identified to the south of the known locations. One was about 5 kilometers $(\mathrm{km})(3$ miles [mi]) to the south and west of Columbine Canyon and was surveyed in June. The total area surveyed was approximately 700 ha $(1,730 \mathrm{ac})$, in which no new populations of I arizonica var. saxosa were found. Another area covering approximately 115 ha (284 ac) located about $8 \mathrm{~km}(5 \mathrm{mi})$ east and south of Columbine canyon was also surveyed this year with the same negative results. One new population was found however. The new population is located about 2,000 $\mathrm{m}(6,561 \mathrm{ft})$ south of Columbine Canyon and covers almost 10 ha (25 ac). Habitat is on the westerly and northerly exposures of large boulders of Rainier Mesa tuff (Figure5-5). Plants at this location were more abundant than at Columbine Canyon. Future long-term monitoring efforts with I. arizonica var. saxosa may involve the establishment of permanent transects at some of the sites to monitor the density of plants over time.

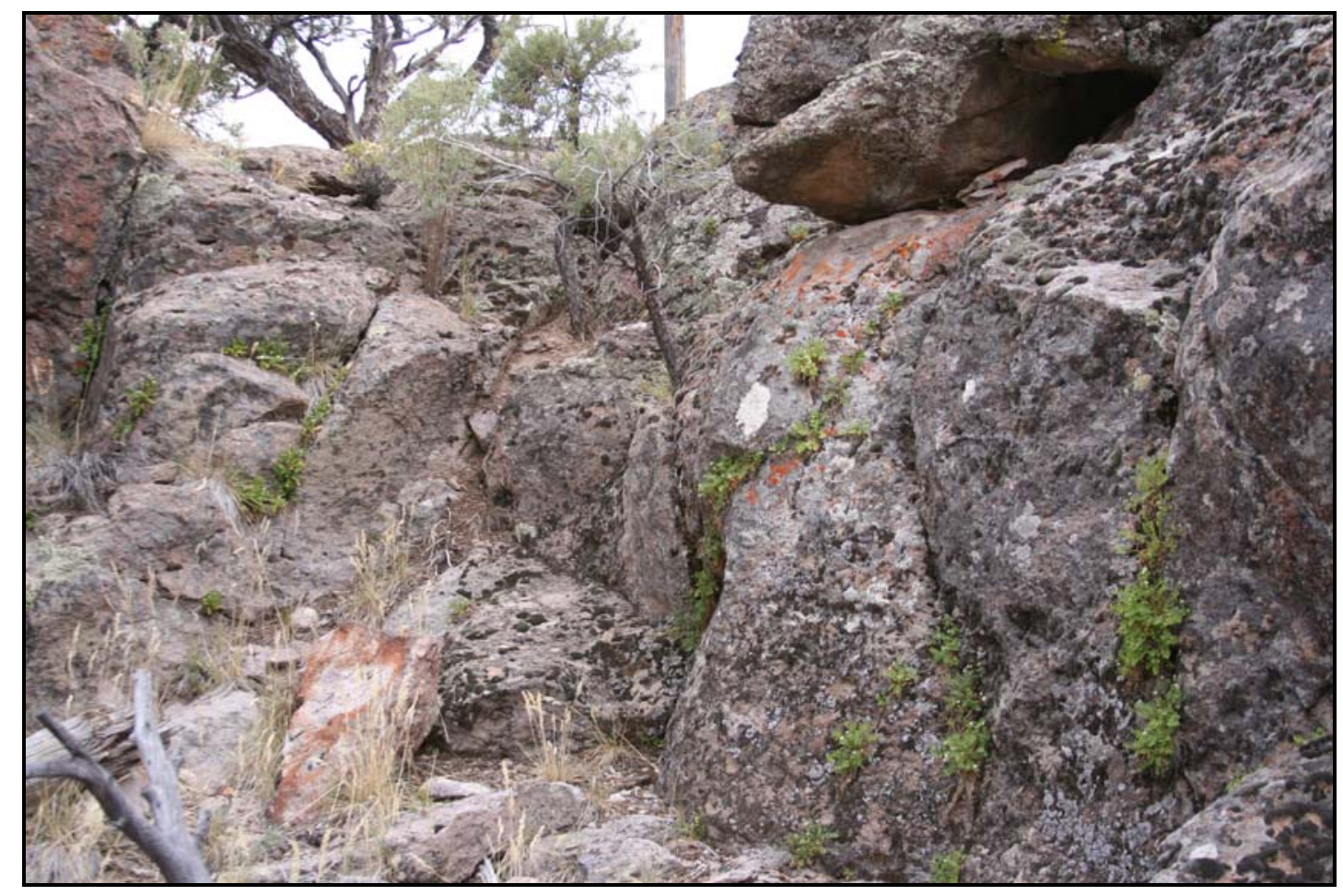

Figure 5-5. I. arizonica var. saxosa growing on north and west faces of large boulders on Pahute Mesa. (Photo by W. K. Ostler, June 2006) 


\subsubsection{Cymopterus ripleyi var. saniculoides}

C. ripleyi var. saniculoides type locality is along the eastern boundary of the NTS (Barneby, 1941) in the Frenchman Flat area. Protection of the species was first proposed by Mozingo and Williams (1980) as a species to "watch." The FWS considered it as a candidate for listing but efforts ceased and attention to the species declined because of the uncertainty surrounding the validity of this variety. In the PLANTS Database (USDA, 2006), The Jepson Manual (Hickman 1993), and from experts in the taxonomy of Cymopterus, as detailed in Blomquist et al. (1995), the two varieties of $C$. ripleyi are not recognized. The NNHP maintains that the two varieties occupy different habitat types, C. ripleyi var. ripleyi occurring at higher elevations, and C. ripleyi var. saniculoides occurring at lower elevations. Based on this differentiation of habitat preference and the lack of mixing of the two varieties, other than in transition zones, the NNHP prefers to recognize the two varieties (notes from 2006 Nevada Rare Plant Workshop, http://heritage.nv.gov/workshop.htm).

This year surveys on the NTS this year for C. ripleyi var. saniculoides began with the intent of confirming the correct variety C. ripleyi at the different collection sites on the NTS. However, as with E. heermannii var. clokeyi, growing conditions were poor at best and an insufficient number of plants were located during some initial surveys. Surveys will be conducted in the future during more favorable growing conditions for this species.

\subsubsection{Entosthodon planoconvexus}

E. planoconvexus was described in 1999 (Shabbara, 1999) based on collections in Egypt, Arizona and Nevada. The collection of E. planoconvexus was made by Dr. L. Stark (Stark et al., 2002) in the 1970s and again in the 1990s. It is "known from four populations globally, one in Utah (Washington Co.), one in Arizona (Pima Co.), one in the northern Egyptian desert, and one in Nye Co., Nevada" (Stark, 2001). It was proposed for endangered status on the NNHP list of rare plant species in 2005 (minutes of 2005 Nevada Rare Plant Workshop, http://heritage.nv.gov/ workshop.htm). The collection site on the NTS is south of Rock Valley in the Specter Range.

Several bryophytes were collected in 2005 and one was tentatively identified as E. planoconvexus. Dr. L. Stark, associate professor at UNLV and expert in bryophyte ecology, later identified the specimens from Rock Valley as E. planoconvexus. Approximately 25 ha (62 ac) to the south and west of the collection site were surveyed during the summer of 2006 with the objective of locating habitat similar to that found at the site where E. planoconvexus was collected in 2005. No similar habitat was found in the area. In the future, surveys for E. planoconvexus will focus on similar geology (limestone), geography (drainages with heavier than normal shrub cover), and exposure (northerly/westerly, no direct exposure to sunlight). 


\subsection{SENSITIVE AND PROTECTED/REGULATED ANIMAL MONITORING}

The NNHP Rare Animal List, Nevada Administrative Code 503 (Hunting, Fishing and Trapping; Miscellaneous Protective Measures), and other sources were reviewed to determine if any changes had been made to the status of species known to occur on the NTS. No noteworthy changes have occurred. The complete list with current designations is found in the Sensitive and Protected/Regulated Animal Species List (see Table 2-1, shown previously).

Surveys of sensitive and protected/regulated animals during 2006 focused on western red-tailed skinks (Eumeces gilberti rubricaudatus), western burrowing owls (Athene cunicularia), kangaroo mice (Microdipodops spp.), bats, feral horses (Equus caballus), mule deer (Odocoileus

hemionus), and mountain lions (Puma concolor). Opportunistic sightings of other sensitive and protected/regulated animals, such as raptors and pronghorn antelope (Antilocapra americana), were also recorded. Groups of antelope are commonly observed along the Mercury Highway from Mercury to Frenchman Flat and along the 5-01 Road. Observations occurring in all months of the year strongly suggest this population has become resident during the last 5 years or more. We recorded 12 antelope road-kills in this region from 2001 to 2006. Additionally, surveys for the sensitive southeast Nevada springsnail (Pyrgudopsis turbatrix) were conducted this year as described in Section 7.4.

\subsection{Western Red-tailed Skink Surveys}

The western red-tailed skink (Figure 6-1), hereafter referred to as skink, is considered a sensitive species by the NNHP, and has an "Evaluate" status for monitoring on the NTS. This means that there is insufficient information on its distribution and abundance to determine if it is threatened and, therefore, whether it warrants protection and monitoring or not.

In Nevada, it is known from the Newberry Mountains, Clark County ( 2 records; Marjorie Barrick Museum, University of Nevada Las Vegas [UNLV], Nevada Division of Wildlife Database); McCullough Mountains, Clark County (2 records; Banta, 1962); Sheep Mountains, Clark and Lincoln Counties (2 records; Hardy, 1948); Spring Mountains (26 records; Banta, 1962 [6 specimens]; Monte L. Bean Museum, Brigham Young University [2 specimens]; UNLV [18 records]); Las Vegas Valley, Clark County (1 specimen, UNLV); Grapevine Peak, Nye County (at least 2 records; Rodgers and Fitch, 1947); and Nevada Test Site, Nye County (7 records; Medica et al., 1990 [4 records]; Boone and Sowell, 1999 [1 record]; EGIS faunal database [2 records]). On the NTS, it is known from four locations (Figure 6-2). Although found in dry, rocky areas, skinks tend to be more abundant in rocky areas near intermittent or permanent streams and springs (Stebbins, 2003; Morrison and Hall, 1999). Therefore, we concentrated our sampling at locations in wet or rocky areas. 


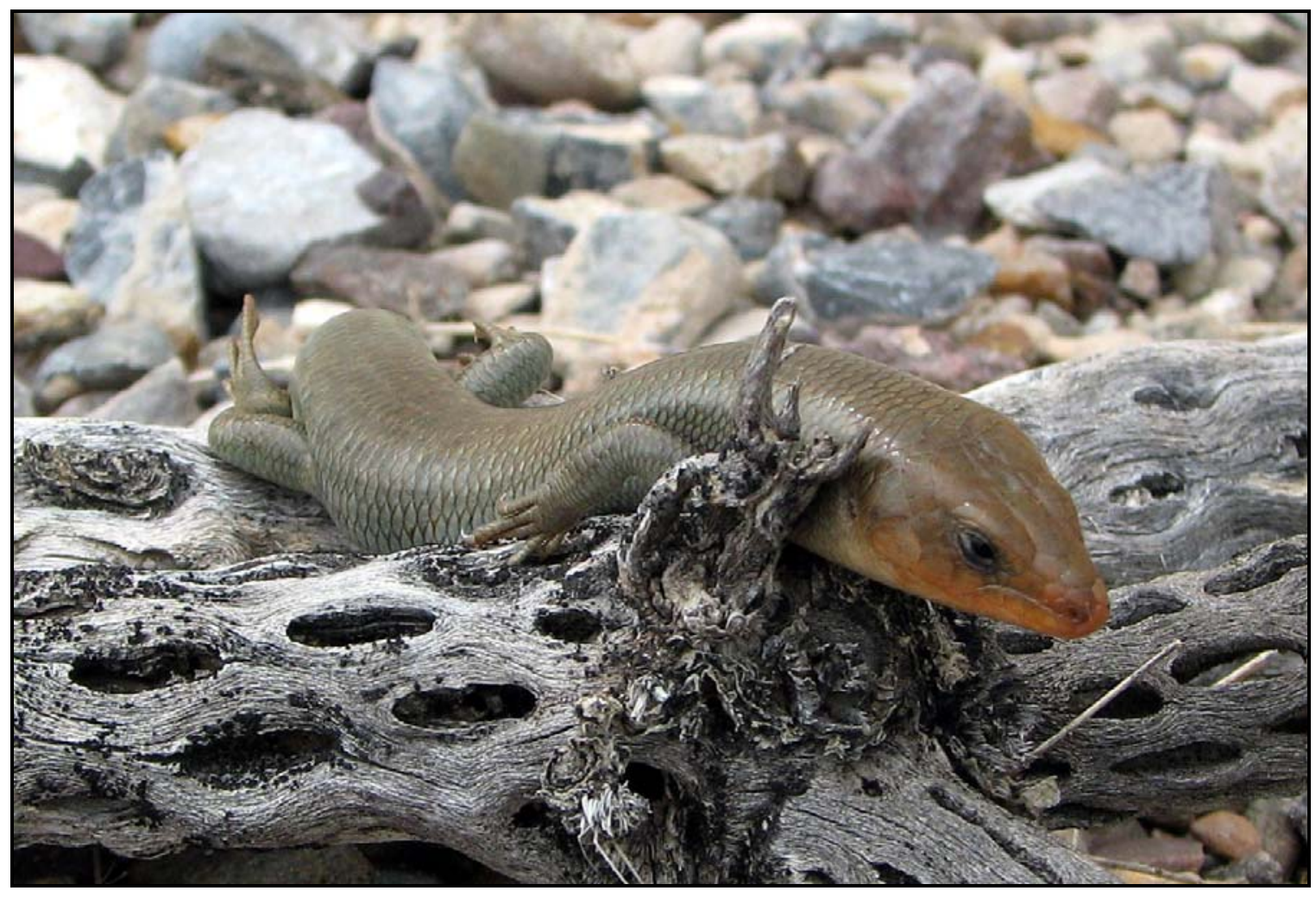

Figure 6-1. Western red-tailed skink (Eumeces gilberti rubricaudatus) captured at Twin Spring, Site \#9 (snout-vent length 91 millimeter). (Photo by D. B. Hall, May 11, 2006)

The main objective of the skink surveys is to determine its distribution on the NTS. A pilot study was initiated this year to determine if it was feasible to capture skinks and investigate what techniques were most effective in capturing them. The two primary techniques investigated were trap arrays with drift fences (Figure 6-3) and funnel traps without drift fences (Figure 6-4). Trap arrays usually consisted of 10 traps including buried cans $(15.0$ centimeters [cm] wide x $30.3 \mathrm{~cm}$ deep [5.9 x 11.9 inches (in.)]), buried plastic buckets $(29.0 \mathrm{~cm}$ wide x $26.5 \mathrm{~cm}$ deep [11.4 x $10.4 \mathrm{in}$.] or $29.0 \mathrm{~cm}$ wide $\times 35.7 \mathrm{~cm}$ deep [11.4 x $14.1 \mathrm{in}]$.$) , and funnel traps (61.0 \mathrm{~cm}$ long $\mathrm{x}$ $21.0 \mathrm{~cm}$ wide $\times 21.0 \mathrm{~cm}$ tall [24.0 $\times 8.3 \times 8.3 \mathrm{in}$.]) connected by a drift fence made of wooden stakes and black plastic. In many areas, the topography and lack of soil made it nearly impossible to use drift fences so funnel traps were set near rocks or vegetation to try and direct the animals into the trap. Usually, 20-30 traps were set in an area due to logistical constraints of carrying bulky traps over rough terrain by two to three people. Other objectives of the pilot study included (a) trapping at historic locations to see if skinks still occurred at these sites, (b) trapping in a variety of habitats to look at habitat preference, (c) determining the minimum length of time required to catch skinks at a given site, and (d) capturing Great Basin skinks (Eumeces skiltonianus) for comparison.

A total of 9 skinks were captured in 6,092 trap days (0.1 percent, 1 skink/677 trap days) (Table 6-1). To our knowledge, this is a new Nevada record for most skinks caught in a study. Skinks were captured at 7 of 48 locations, including 1 historic location and 6 new ones (Figure 6-2). Elevation at skink capture sites ranged from $1,310 \mathrm{~m}(4,297 \mathrm{ft})$ to $1,848 \mathrm{~m}$ 


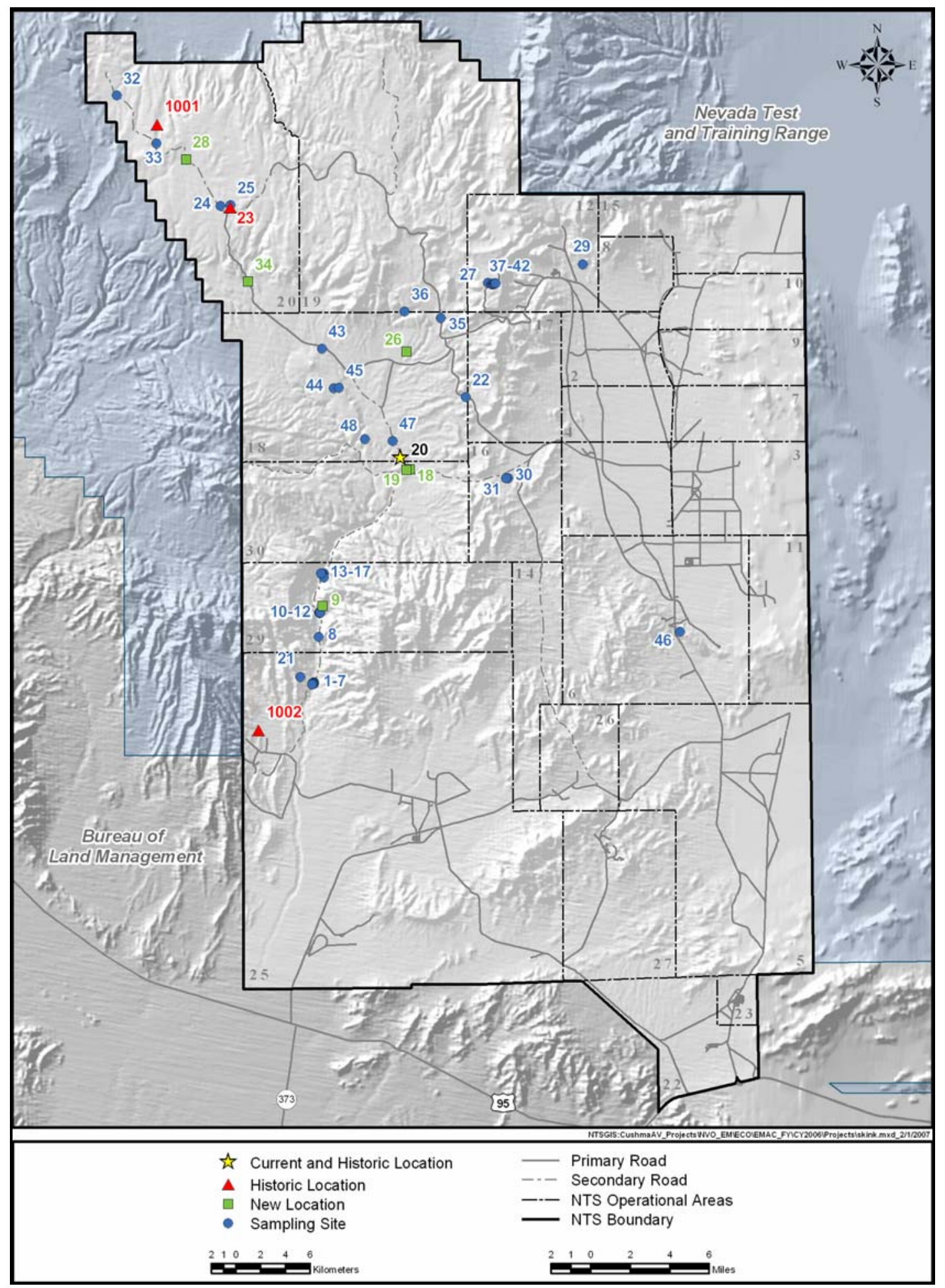

Figure 6-2. Western red-tailed skink distribution on the NTS including historic locations and sites sampled for skinks during 2006. 


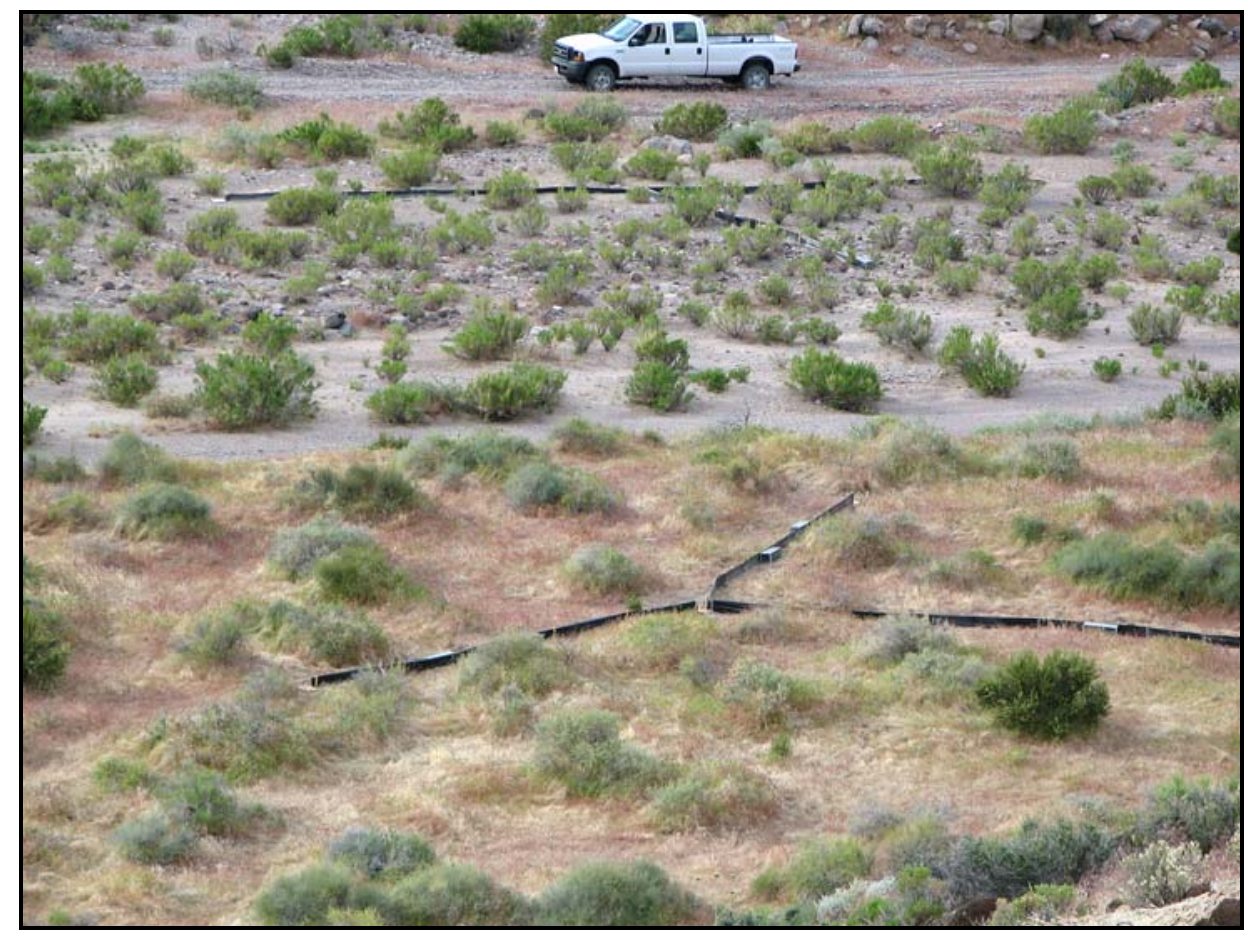

Figure 6-3. Overview of trap arrays at Site \#14 (Yellow Rock Springs Wash \#2 and \#1). (Photo by D. B. Hall, May 16, 2006)

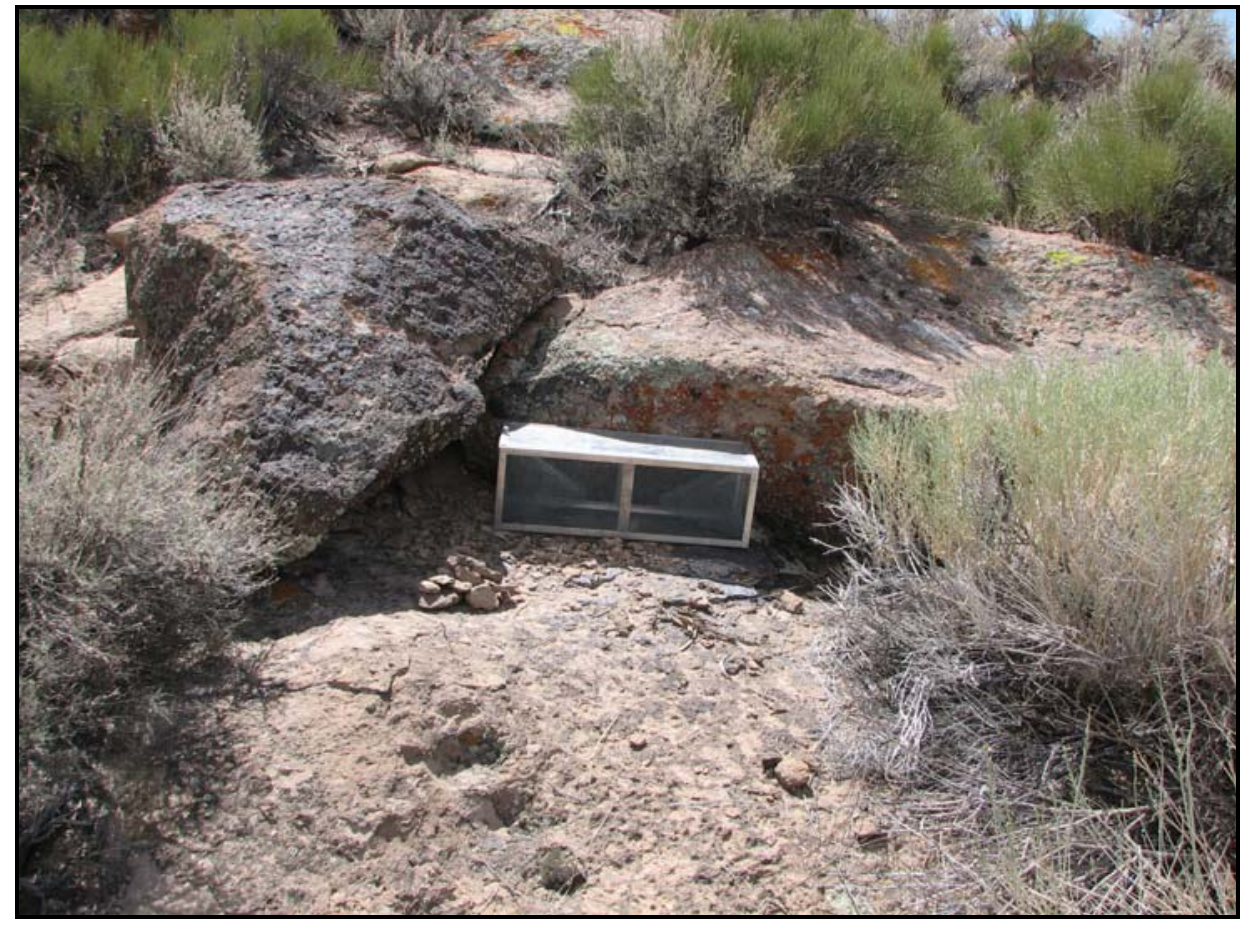

Figure 6-4. Funnel trap where a skink was captured, set near rocks at Site \#34 (Buckboard Mesa Road 20a-113). (Photo by Derek Hall, September 5, 2006) 
Table 6-1. Number of skinks and other reptiles captured by NTS area, site, and survey period.

\begin{tabular}{|c|c|c|c|c|c|c|c|c|c|c|c|c|c|c|c|c|c|c|c|c|c|c|c|c|c|c|}
\hline \multirow[b]{2}{*}{$\begin{array}{l}\text { Site } \\
\text { Number }\end{array}$} & \multirow[b]{2}{*}{$\begin{array}{l}\text { NTS } \\
\text { Area }\end{array}$} & \multirow[b]{2}{*}{ Dates in 2006} & \multirow[b]{2}{*}{$\begin{array}{l}\text { Trap } \\
\text { Days }\end{array}$} & \multicolumn{10}{|c|}{ Lizards } & \multicolumn{11}{|c|}{ Snakes } & \multirow{2}{*}{\multicolumn{2}{|c|}{ 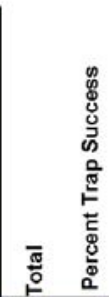 }} \\
\hline & & & & 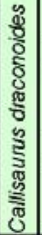 & 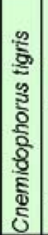 & 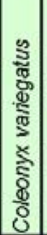 & 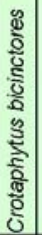 & 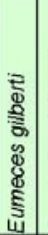 & 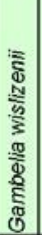 & 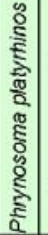 & 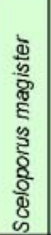 & 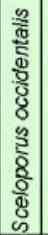 & 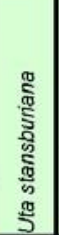 & 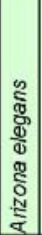 & 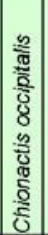 & 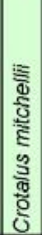 & 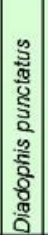 & 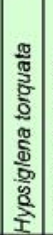 & 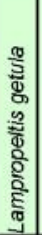 & 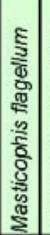 & 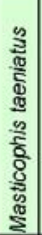 & 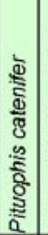 & 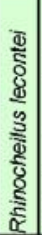 & 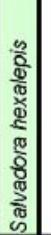 & & \\
\hline 1 & 25 & $4 / 24-4 / 28 ; 5 / 1-5 / 4$ & 140 & & & & & & & & 9 & & 14 & & & & & & & & & & & & \begin{tabular}{l|l}
23 \\
\end{tabular} & 16.4 \\
\hline 2 & 25 & $\begin{array}{c}4 / 24-4 / 28 ; 5 / 1-5 / 4 ; 5 / 8 \\
5 / 11\end{array}$ & 100 & & 1 & & & & & & 2 & & 5 & & & & & & 1 & & & & & & 9 & 9.0 \\
\hline 3 & 25 & $\begin{array}{c}4 / 24-4 / 28: 5 / 1-5 / 4: 5 / 8 \\
5 / 11\end{array}$ & 100 & $P$ & & & & & & & & & 4 & & 1 & & & & & & & & & & 5 & 5.0 \\
\hline 4 & 25 & $\begin{array}{c}4 / 24-4 / 28: 5 / 1-5 / 4 ; 5 / 8 \\
5 / 11\end{array}$ & 100 & & 1 & & & & & 1 & 3 & & 2 & & & & & & 1 & & & & & 1 & 9 & 9.0 \\
\hline 5 & 25 & $4 / 24-4 / 28: 5 / 1-5 / 4$ & 70 & & \begin{tabular}{|l|}
2 \\
\end{tabular} & & & & & $P$ & & & 2 & & & & & & & \begin{tabular}{|l|}
2 \\
\end{tabular} & & & & & 6 & 8.6 \\
\hline 6 & 25 & $4 / 24-4 / 28: 5 / 1-5 / 4$ & 70 & & & & & & & & & & 1 & & & & & & & & & & & & 1 & 1.4 \\
\hline 7 & 25 & $4 / 24-4 / 28: 5 / 1-5 / 4$ & 70 & & \begin{tabular}{|l|}
1 \\
\end{tabular} & & & & & & & & & & & & & & & & & & & & 1 & 1.4 \\
\hline 8 & 29 & $5 / 8-5 / 11$ & 60 & & & & & & & & 13 & & 3 & & & & & & & 1 & & & & & 17 & 28.3 \\
\hline 9 & 29 & $5 / 8-5 / 11$ & 90 & & & & & 2 & & & 4 & & 4 & & & & & & & & & & & & 10 & 11.1 \\
\hline 10 & 29 & $5 / 8-5 / 11: 5 / 15-5 / 18$ & 60 & & \begin{tabular}{|l|}
2 \\
\end{tabular} & & & & $\mathrm{P}$ & & & & 1 & & & & & & & 1 & & & & & 4 & 6.7 \\
\hline 11 & 29 & $5 / 8-5 / 11: 5 / 15-5 / 18$ & 60 & & \begin{tabular}{|l|}
1 \\
\end{tabular} & & & & & & & & 5 & 2 & & & & & & & & & & & 8 & 13.3 \\
\hline 12 & 29 & $5 / 8-5 / 11: 5 / 15-5 / 18$ & 60 & & 2 & & & & 1 & & 2 & & 2 & & & & & & & & 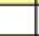 & & & 11 & 8 & 13.3 \\
\hline $13-15$ & 29 & $5 / 15-5 / 18: 5 / 22-5 / 25$ & 180 & 1 & 21 & \begin{tabular}{|l|}
2 \\
\end{tabular} & & & $P$ & & 7 & & 1 & & & & & & & 1 & & \begin{tabular}{l|l}
1 & $y$ \\
\end{tabular} & & & 34 & 18.9 \\
\hline 16 & 29 & $5 / 15-5 / 18$ & 90 & & & & & & & & 6 & & 5 & & & & & & & $P$ & 1 & \begin{tabular}{l|l}
$P$ \\
\end{tabular} & & & 12 . & 13.3 \\
\hline 17 & 29 & $5 / 15-5 / 18$ & 60 & & \begin{tabular}{|c|}
3 \\
\end{tabular} & & & & & & & & 4 & & & & & & & & & & & & 7 & 11.7 \\
\hline 18 & 30 & $5 / 22-5 / 25$ & 60 & & \begin{tabular}{|l|l|}
3 \\
\end{tabular} & & & 1 & $\mathrm{P}$ & $P$ & 5 & & 8 & & & & & & & & & & & & 17 & 28.3 \\
\hline 19 & 30 & $5 / 22-5 / 25$ & 90 & & \begin{tabular}{|l|}
7 \\
\end{tabular} & & 1 & 1 & & & 5 & & 4 & & & & & & & & & & & & 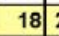 & 20.0 \\
\hline 20 & 18 & $\begin{array}{c}5 / 22-5 / 25: 6 / 5-6 / 8 ; \\
9 / 11-9 / 14 ; 9 / 18-9 / 20 \\
9 / 26-9 / 29 ; 10 / 2-10 / 5 \\
10 / 9-10 / 11\end{array}$ & 561 & & 4 & & 1 & 2 & 1 & 1 & 8 & & 32 & & & & & $P$ & & & 1 & 1 & 1 & & 52 & 9.3 \\
\hline 21 & 25 & $5 / 30-6 / 5$ & 96 & & \begin{tabular}{|l|}
1 \\
\end{tabular} & \begin{tabular}{|l|l|}
2 & \\
\end{tabular} & 1 & & & & 5 & & 4 & & & & & & & & & & & & 13 & 13.5 \\
\hline 22 & 18 & $6 / 5-6 / 8$ & 60 & & \begin{tabular}{|l|}
1 \\
\end{tabular} & & & & & & 1 & 10 & 8 & & & & & & & & & & & & 20 & 33.3 \\
\hline 23 & 20 & $\begin{array}{c}6 / 12-6 / 15 ; 7 / 5-7 / 10 \\
9 / 5-9 / 11\end{array}$ & 390 & & 3 & & & & & & & 14 & 11 & & & & & & & & 2 & & & & 30 & 7.7 \\
\hline 24 & 20 & $9 / 5-9 / 11$ & 42 & & \begin{tabular}{|l|}
1 \\
\end{tabular} & & & & & & & \begin{tabular}{|l|}
1 \\
\end{tabular} & & & & & & & & & & & & & 2 & 4.8 \\
\hline 25 & 20 & $6 / 12-6 / 15 ; 7 / 5-7 / 10$ & 390 & & & & & & & & & & 28 & & & & & & & & & & & & 28 & 7.2 \\
\hline 26 & 18 & $6 / 5-6 / 8 ; 7 / 5-7 / 10$ & 240 & & \begin{tabular}{|l|}
2 \\
\end{tabular} & \begin{tabular}{|l|l}
1 & \\
\end{tabular} & $P$ & 1 & & & 8 & 14 & 2 & & & & & & & & & & & & 28 & 11.7 \\
\hline 27 & 12 & $\begin{array}{c}6 / 6-6 / 8: 6 / 13-6 / 15: \\
7 / 11-7 / 13\end{array}$ & 104 & & & & & & & & & 3 & 1 & & & & & & & & & 1 & & & 5 & 4.8 \\
\hline 28 & 20 & $6 / 12-6 / 15 ; 7 / 5-7 / 10$ & 160 & & & & & 1 & & $P$ & & \begin{tabular}{|l|}
7 \\
\end{tabular} & 5 & & & & & & & & 3 & & & & \begin{tabular}{l|l}
16 \\
\end{tabular} & 10.0 \\
\hline 29 & 12 & $7 / 10-7 / 13: 7 / 17-7 / 20$ & 180 & & \begin{tabular}{|l|}
1 \\
\end{tabular} & & & & & & 11 & 1 & 6 & & & & & & & & & & & & 19 & 10.6 \\
\hline 30 & 16 & $7 / 17-7 / 20: 7 / 24-7 / 27$ & 180 & & \begin{tabular}{|l|}
1 \\
\end{tabular} & & & & & $P$ & 2 & 1 & 6 & & & & & & 1 & & & & & & 11 & 6.1 \\
\hline
\end{tabular}


Table 6-1. Number of skinks and other reptiles captured by NTS area, site, and survey period. (Continued)

\begin{tabular}{|c|c|c|c|c|c|c|c|c|c|c|c|c|c|c|c|c|c|c|c|c|c|c|c|c|c|c|}
\hline \multirow[b]{2}{*}{$\begin{array}{c}\text { Site } \\
\text { Number }\end{array}$} & \multirow[b]{2}{*}{$\begin{array}{l}\text { NTS } \\
\text { Area }\end{array}$} & \multirow[b]{2}{*}{ Dates in 2006} & \multirow[b]{2}{*}{$\begin{array}{l}\text { Trap } \\
\text { Days }\end{array}$} & \multicolumn{10}{|c|}{ Lizards } & \multicolumn{11}{|c|}{ Snakes } & \multirow{2}{*}{\multicolumn{2}{|c|}{ 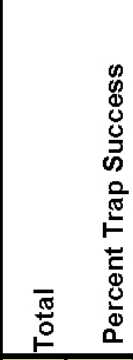 }} \\
\hline & & & & 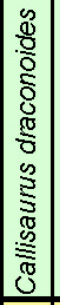 & 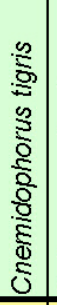 & 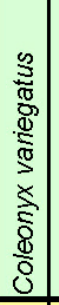 & 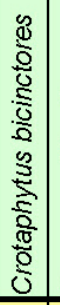 & 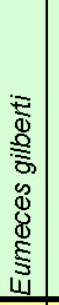 & 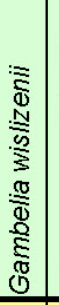 & 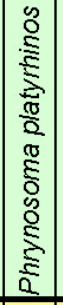 & 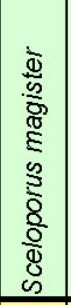 & 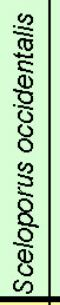 & 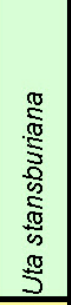 & 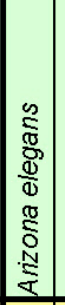 & 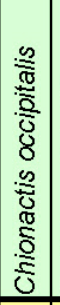 & 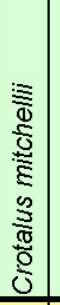 & 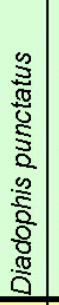 & 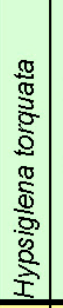 & 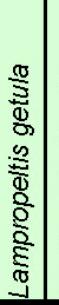 & 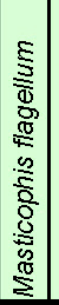 & 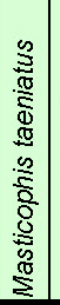 & 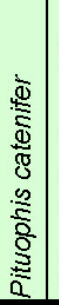 & 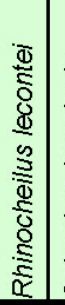 & 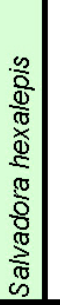 & & \\
\hline 31 & 16 & $7 / 17-7 / 20 ; 7 / 24-7 / 27$ & 180 & & & & & & & & 2 & & 8 & & & 3 & & & 1 & 1 & & $\mathrm{P}$ & & & 15 & 8.3 \\
\hline 32 & 20 & $7 / 24-7 / 27 ; 7 / 31-8 / 3$ & 180 & & & 1 & $\mathrm{P}$ & & & 2 & $P$ & 6 & 5 & & & & & & & & & & & & 14 & 7.8 \\
\hline 33 & 20 & $7 / 31-8 / 3 ; 8 / 7-8 / 10$ & 180 & & 3 & & & & & & & & 7 & & & & & & & & & & & & 10 & 5.6 \\
\hline 34 & 20 & $7 / 31-8 / 3 ; 8 / 7-8 / 10$ & 180 & & 1 & & & 1 & & & & 2 & 2 & & & & 1 & & & & & & & & 7 & 3.9 \\
\hline 35 & 18 & $8 / 7-8 / 10 ; 8 / 21-8 / 24$ & 180 & & 6 & & & & & & & 3 & 2 & & & & & & & & 2 & & & & 13 & 7.2 \\
\hline 36 & 18 & $8 / 21-8 / 24$ & 60 & & & & & & & & & 3 & 2 & & & & & & & & $\mathrm{P}$ & & & & 5 & 8.3 \\
\hline 37 & 12 & $8 / 21-8 / 24 ; 8 / 28-8 / 30$ & 25 & & & & & & & & & 1 & & & & & & & & & & & & & 1 & 4.0 \\
\hline 38 & 12 & $8 / 21-8 / 24 ; 8 / 28-8 / 30$ & 25 & & & & & & & & & & 1 & & & & & & & & & & & & 1 & 4.0 \\
\hline 39 & 12 & $8 / 21-8 / 24 ; 8 / 28-8 / 30$ & 25 & & & & & & & & & 2 & & & & & & & & & 1 & & & & 3 & 12.0 \\
\hline 40 & 12 & $8 / 21-8 / 24 ; 8 / 28-9 / 5$ & 55 & & & & & & & & & 2 & & & & & & & & & & & & & 2 & 3.6 \\
\hline 41 & 12 & $8 / 21-8 / 24 ; 8 / 28-8 / 30$ & 25 & & & & & & & & & 1 & & & & & & & & & & & & & 1 & 4.0 \\
\hline 42 & 12 & $8 / 21-8 / 24 ; 8 / 28-8 / 30$ & 25 & & & & & & & & & & & & & & & & & & & & & & 0 & 0.0 \\
\hline 43 & 18 & $8 / 28-8 / 29 ; 9 / 5-9 / 11$ & 209 & & & & & & & & & 3 & 3 & & & & & & & & & & & & 6 & 2.9 \\
\hline 44 & 18 & $8 / 28-8 / 29 ; 9 / 5-9 / 11$ & 175 & & & & & & & & & & 4 & & & & & & & & & & & & 4 & 2.3 \\
\hline 45 & 18 & $\begin{array}{c}8 / 28-8 / 29 ; 9 / 5-9 / 14 \\
9 / 18-9 / 20\end{array}$ & 185 & & & & 1 & & & & & 1 & & & & & & & & & 1 & 1 & & & 4 & 2.2 \\
\hline 46 & 6 & $9 / 11-9 / 14 ; 9 / 18-9 / 20$ & 150 & & & & & & & & 1 & & & & & & & & & & & & & & 1 & 0.7 \\
\hline 47 & 18 & $\begin{array}{c}9 / 27-9 / 29 ; 10 / 2-10 / 5 \\
10 / 9-10 / 11 \\
\end{array}$ & 190 & & & & & & & & 7 & 1 & 13 & & & & & & & 1 & & & & & 22 & 11.6 \\
\hline \multirow[t]{2}{*}{48} & 18 & $9 / 26-9 / 29 ; 10 / 2-10 / 5$ & 180 & & & & & & & & & 1 & 15 & & & & & & & & & & & & 16 & 8.9 \\
\hline & & Total: & 6,092 & 1 & 68 & 6 & 4 & 9 & 2 & 4 & 101 & 77 & 230 & 2 & 1 & 3 & 1 & 0 & 4 & 7 & 11 & 4 & 1 & 2 & 538 & 8.8 \\
\hline $\mathrm{mb}$ & site & is found: & & 2 & 22 & 4 & 6 & 7 & 5 & 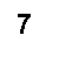 & 20 & 20 & $3 r$ & 1 & 1 & 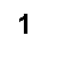 & 1 & 1 & 4 & 7 & 8 & 0 & 1 & 2 & & \\
\hline
\end{tabular}

$\mathrm{P}=$ observed but not captured 


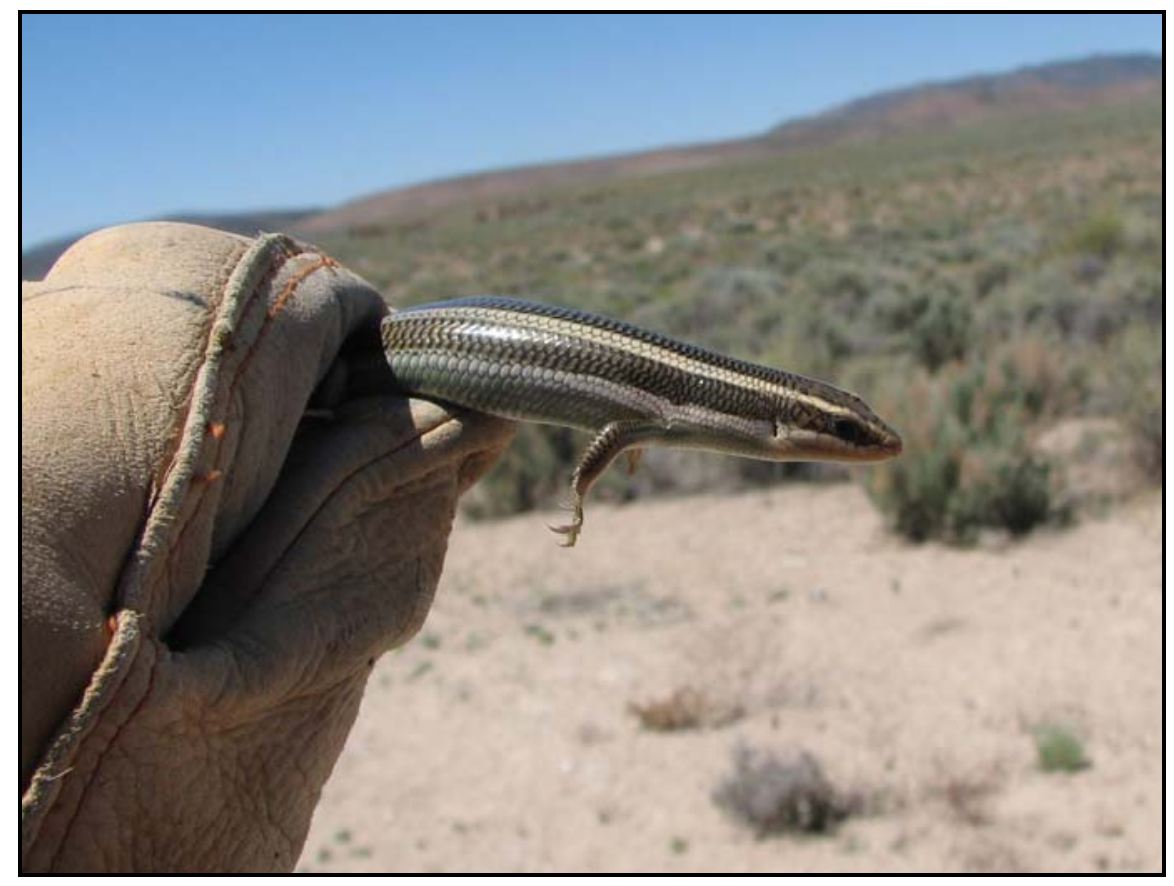

Figure 6-5. Western red-tailed skink (Eumeces gilberti rubricaudatus) captured at Site \#20, showing striped color phase (snout-vent length 89 millimeters). (Photo by D. B. Hall, May 25, 2006)

$(6,061 \mathrm{ft})$ (average 1,360 m [4,461 ft]) above sea level. Two color phases were noted with some individuals being solid olive green to brown (Figure 6-1, shown previously) and some having stripes (Figure 6-5) even though snout-vent lengths were similar.

All skinks were captured in funnel traps set near rocks or vegetation. No skinks were caught in trap arrays, which indicates that drift fences are not necessary to capture skinks. This significantly reduces the amount of effort and cost required to trap skinks. Two skinks were caught (in the same funnel trap) at Site \#20, a historic location. Traps were set in the vicinity of two other historic locations with no success. Five of the seven locations where skinks were caught were near springs or mesic washes. The other two sites were on dry, rocky hillsides. Two skinks were captured on the second day of trapping, four were captured on the third day, and three were captured on the sixth day. Typically, there were six nights of trapping at each site over a 2-week period. No Great Basin skinks were captured this year.

Six skinks were captured during 1,221 trap days in May, 0 captures during 695 trap days in June, 2 captures during 1,315 trap days in July (both on the same day after thunderstorms at 2 different sites), 1 capture during 895 trap days in August, and 0 captures during 1,256 trap days in September. These data suggest that May is the optimal month for trapping, and that during the hot, dry summer it is still possible to catch skinks, especially after thunderstorms, but capture success drops significantly. Additional data are needed to help elucidate the activity patterns of skinks and when they are most readily captured.

During skink trapping, the presence of other reptiles, mammals, and birds were also documented (Figures 6-6 to 6-13) either by capturing them or by observation. This expands the knowledge of the distribution of wildlife across the NTS, especially in areas that have never been sampled before. Including skinks, a total of 538 reptiles was captured (excluding recaptures) or observed, representing 10 of 16 known lizards and 11 of 17 known snakes on the NTS (Table 6-1). 


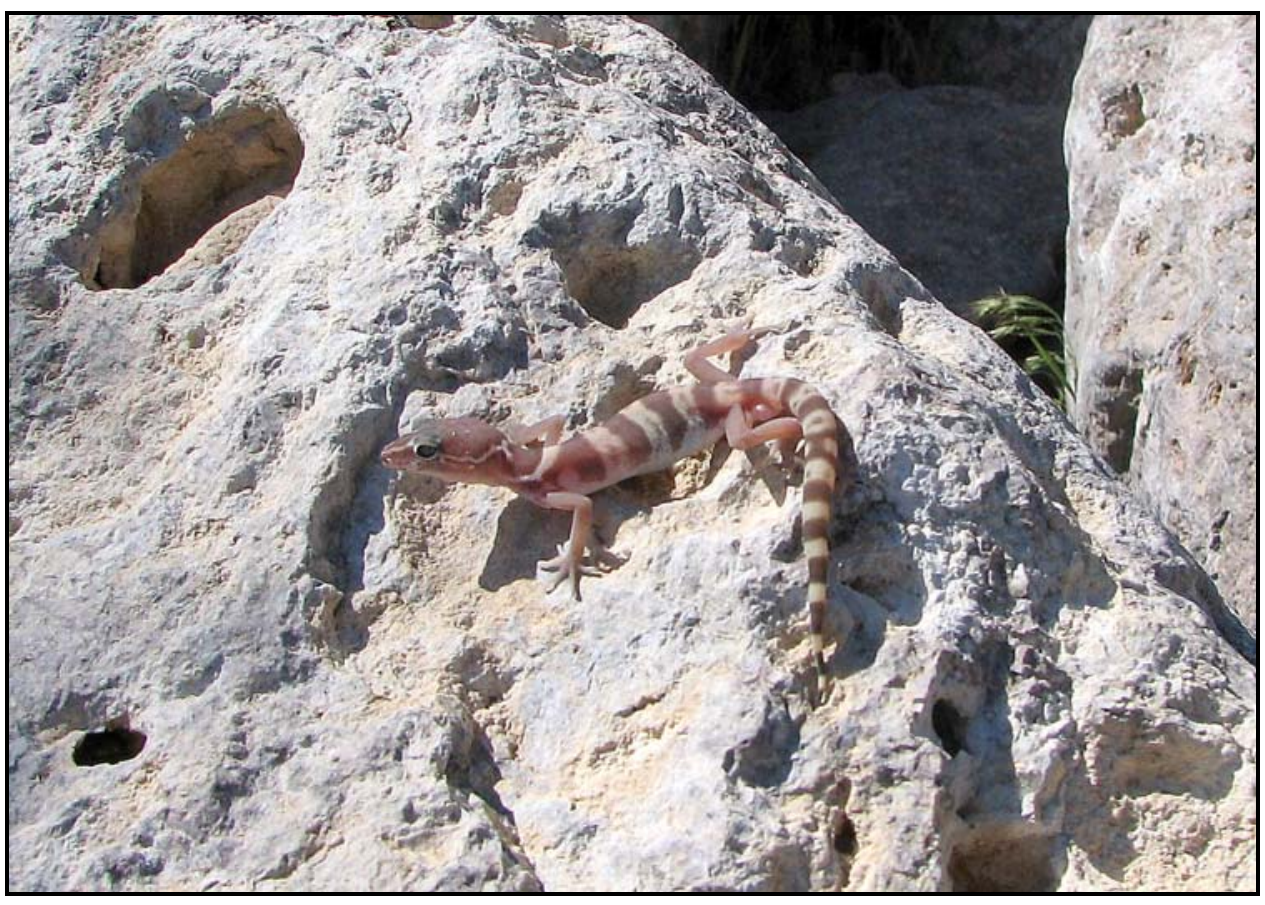

Figure 6-6. Desert-banded gecko (Coleonyx variegatus) captured at Site \#15 (Yellow Rock Springs Wash \#3). (Photo by D. B. Hall, May 18, 2006)

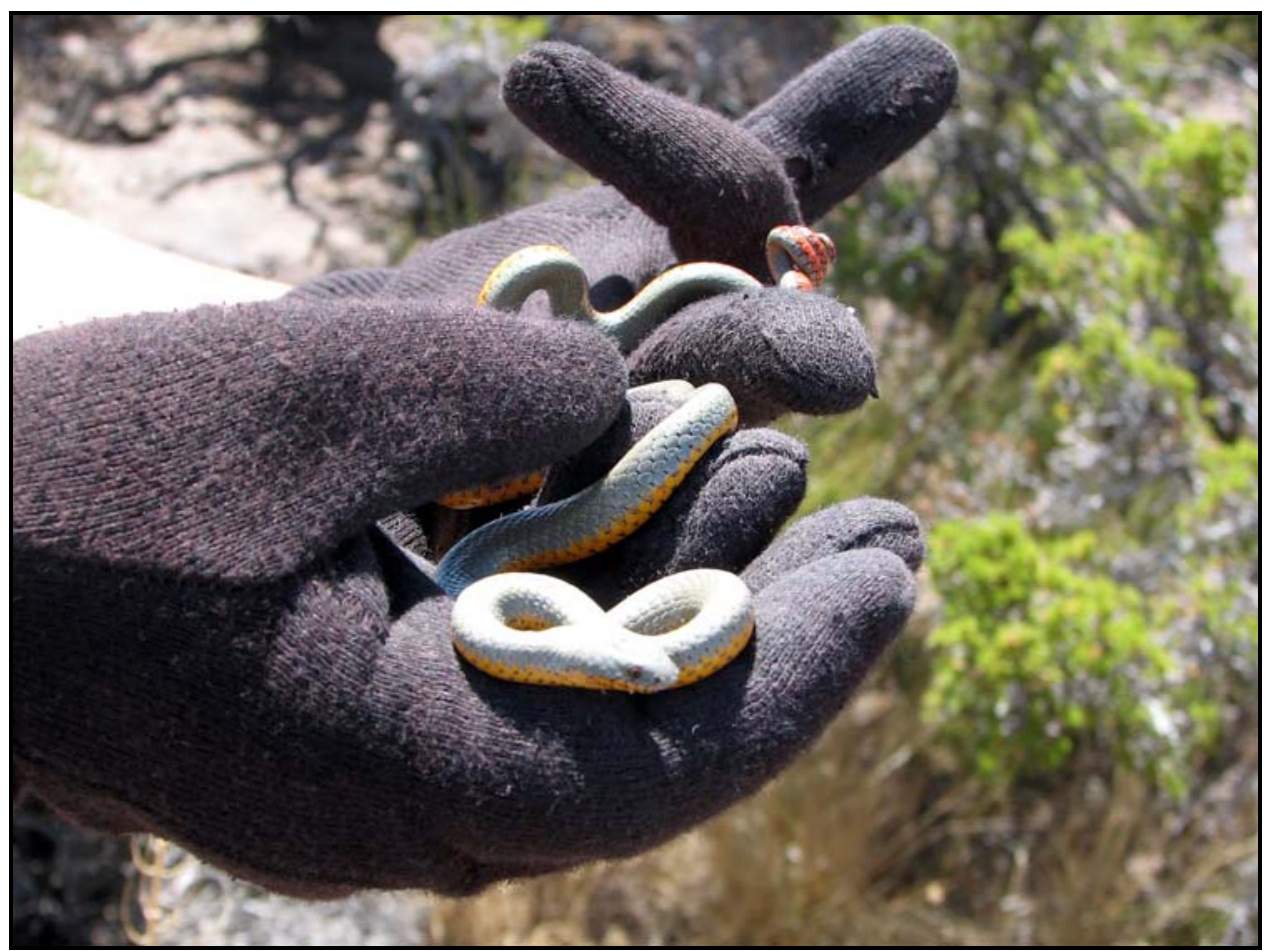

Figure 6-7. $\quad$ Ring-necked snake (Diadophis punctatus) captured at Site \#34 (Buckboard Mesa Road 20a-113). (Photo by D. B. Hall, August 3, 2006) 


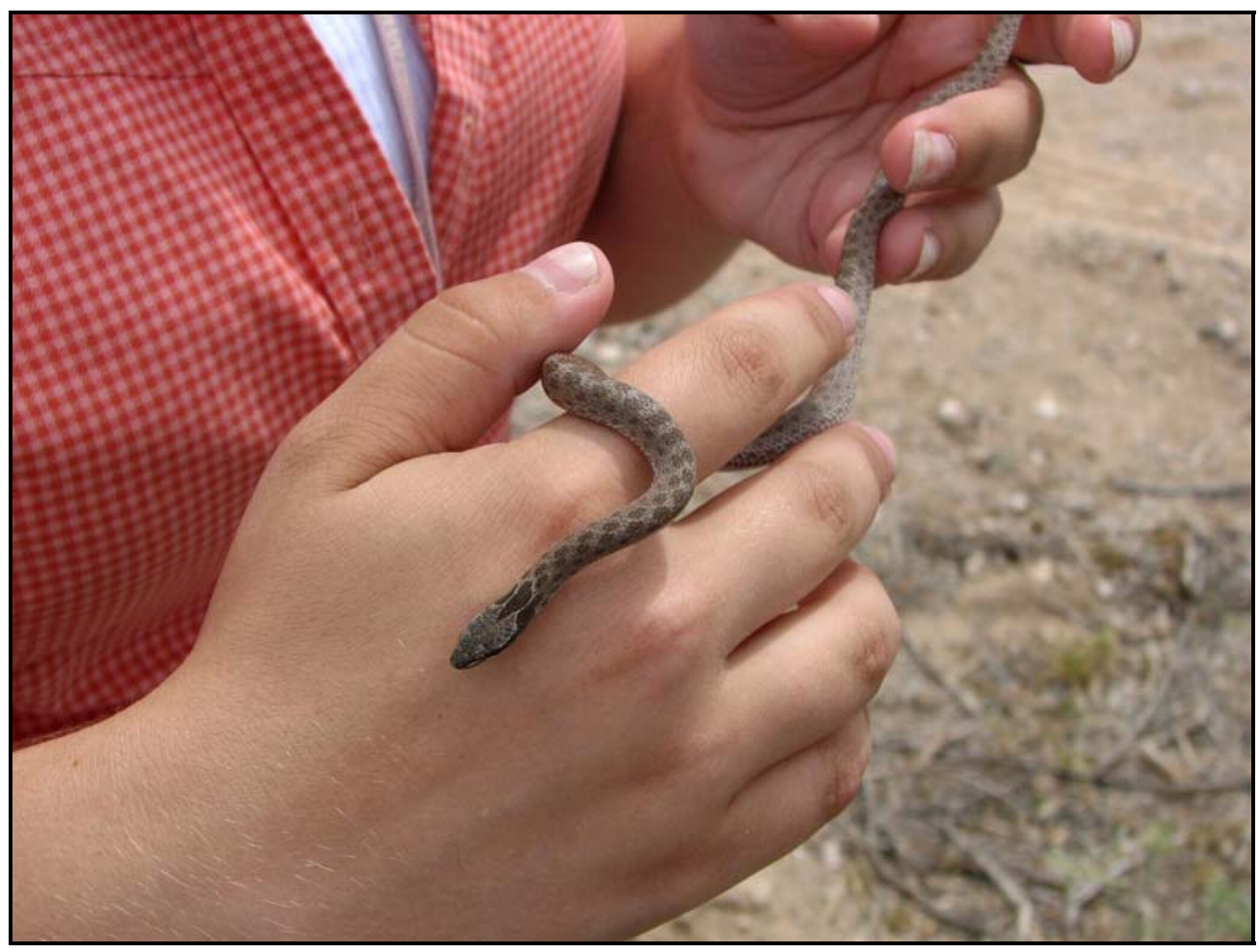

Figure 6-8. Night snake (Hypsiglena torquata) caught under a rock at Site \#20 (Orin Haworth Site). (Photo by D. B. Hall, June 7, 2006)

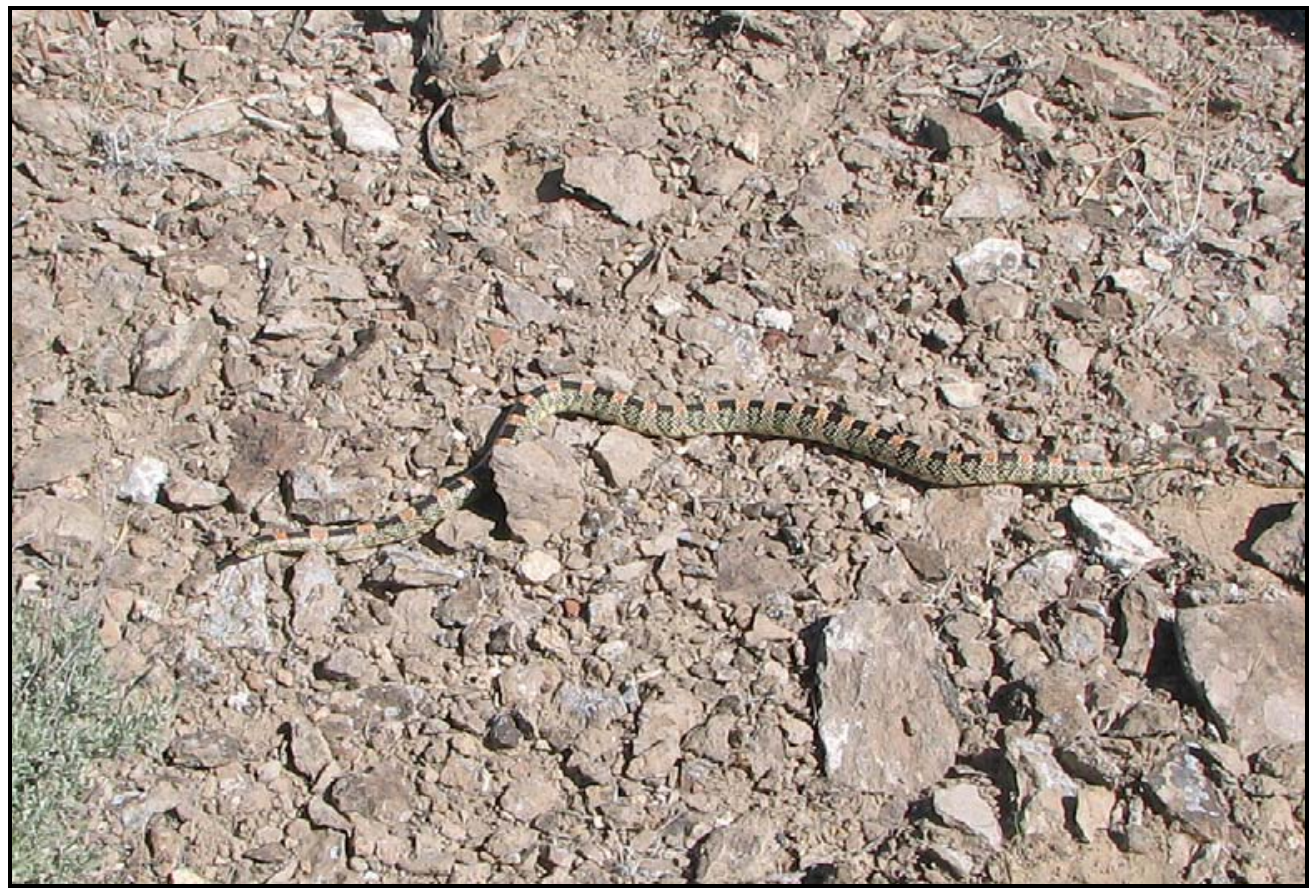

Figure 6-9. Western long-nosed snake (Rhinocheilus lecontei) captured at Site \#20 (Orin Haworth Site). (Photo by D. B. Hall, May 23, 2006) 


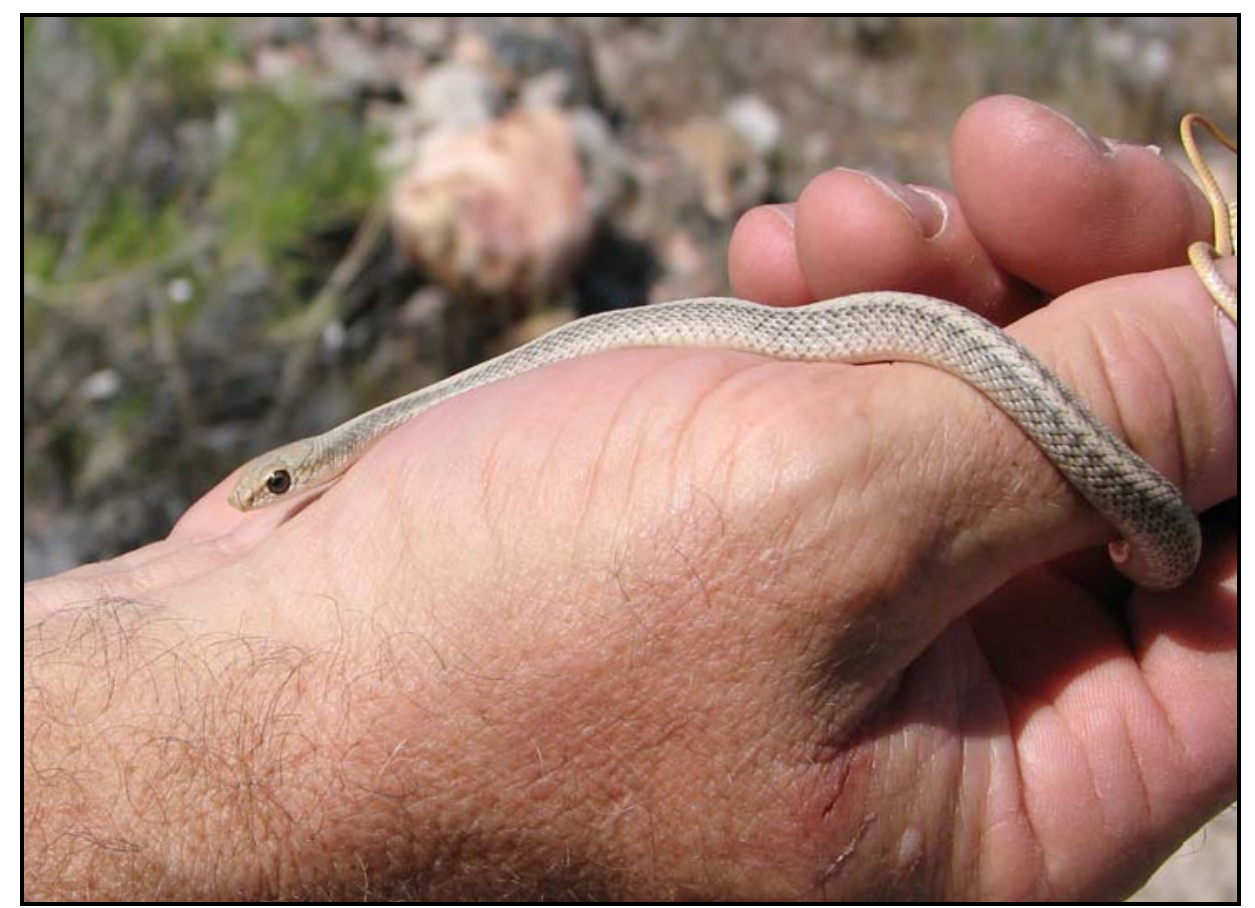

Figure 6-10. Mohave patch-nosed snake (Salvadora hexalepis) captured at Site \#4 (lower 40-mile Wash Plot \#3). (Photo by D. B. Hall, April 28, 2006)

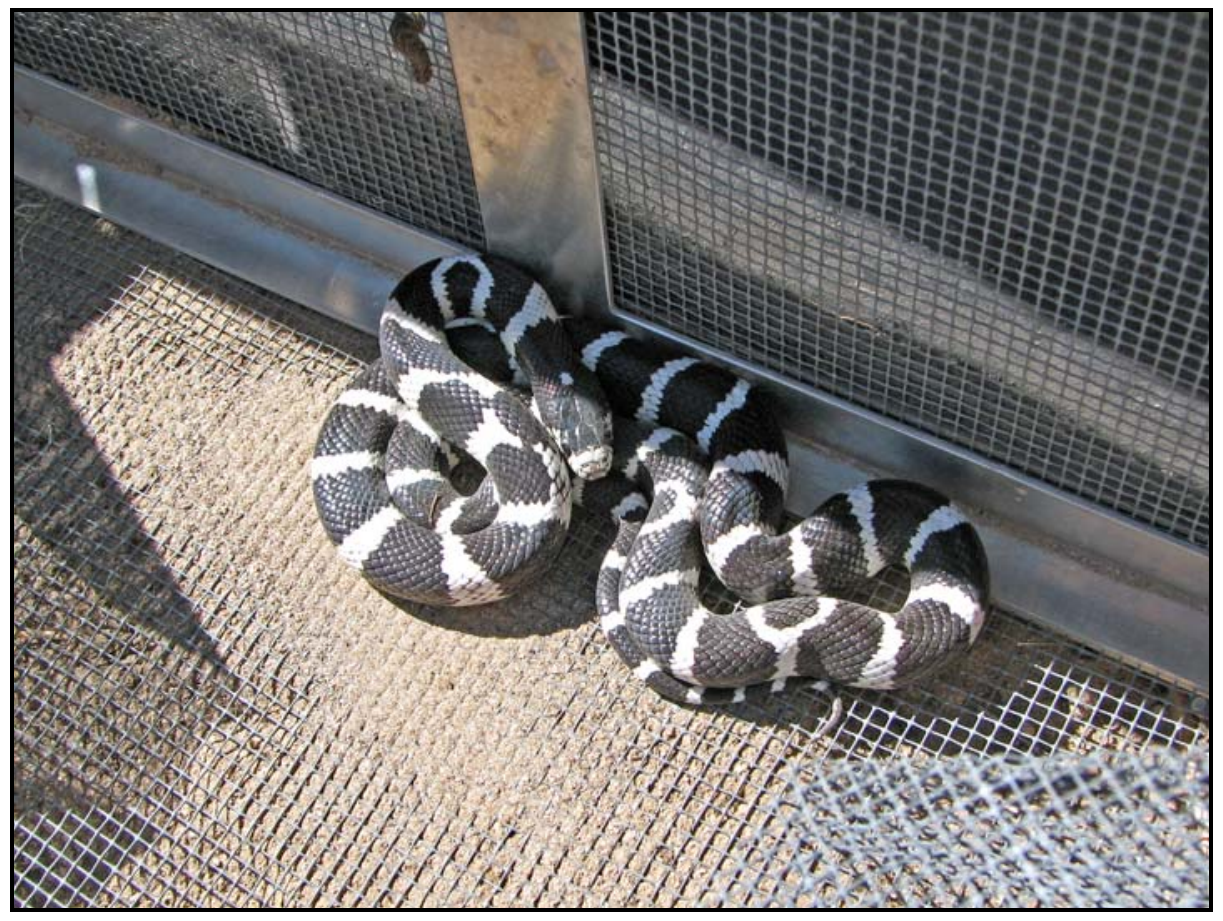

Figure 6-11. California kingsnake (Lampropeltis getula) in funnel trap at Site \#2 (lower 40-mile Wash Plot \#1). (Photo by D. B. Hall, April 28, 2006) 


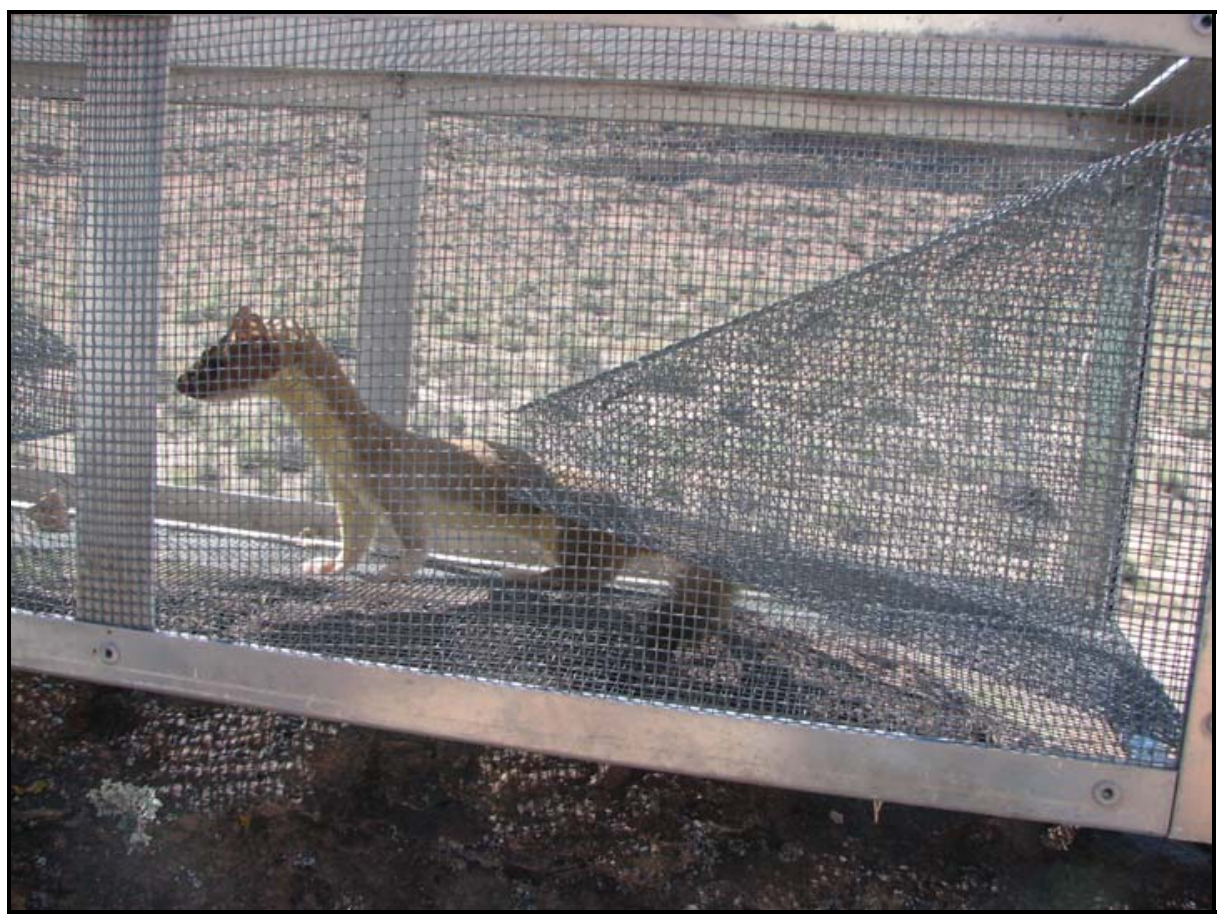

Figure 6-12. Long-tailed weasel (Mustela frenata) captured at Site \#19 (30-2C Boulder Slope). (Photo by D. B. Hall, May 24, 2006)

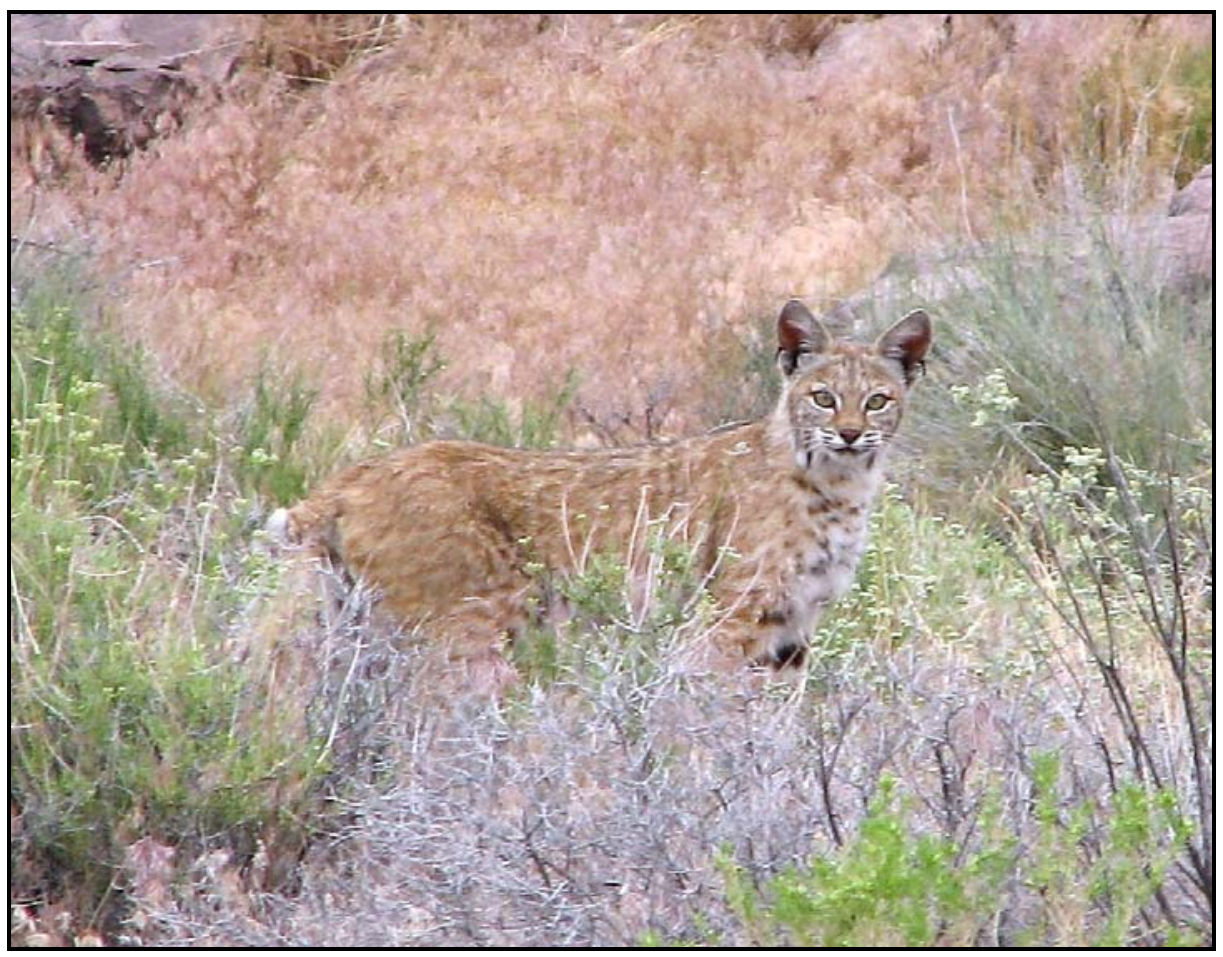

Figure 6-13. Bobcat (Lynx rufus) near Site \#8 (40-mile Wash ledges). (Photo by D. B. Hall, May 16, 2006) 
Overall trap success for reptiles was 8.8 percent (538 captures/6,092 trap days). For all reptile species, capture success was similar between arrays and non-arrays, 9.4 percent (101 captures/1,070 trap days) and 8.7 percent (437 captures/5,022 trap days); respectively. Across all arrays, capture success was 4.9 percent (11 captures/225 trap days) in cans, 5.2 percent ( 6 captures/115 trap days) in buckets, and 11.5 percent (84 captures/730 trap days) in funnel traps.

More than 200 captures of 15 mammal species were recorded, including a long-tailed weasel (Mustela frenata) (Figure 6-12) and Merriam's shrew (Sorex merriami), and observations of several other mammals (e.g., bobcat [Lynx rufus] [Figure 6-13], desert cottontail [Sylvilagus audubonii]) were noted. Two rock wrens (Salpinctes obsoletus) were captured in funnel traps, and 12 bird species were observed (including a Say's Phoebe [Sayornis saya] nest) during trapping efforts.

\subsection{Western Burrowing Owl}

Western burrowing owl monitoring entailed trapping owls at their burrows. Six new burrow sites were found including four burrows in the Mojave Desert ecoregion and two in the Great Basin Desert ecoregion. This makes a total of 132 known western burrowing owl locations ( 30 owl sightings and 102 burrow sites) on the NTS (Figure 6-14).

Trapping--Burrowing owl trapping was conducted for the second consecutive year. This is a collaborative effort with Dr. Courtney Conway from the University of Arizona. Dr. Conway is working on a Department of Defense Legacy funded project evaluating migratory linkages of western burrowing owls in western North America. This involves trapping and banding burrowing owls and taking feather and blood samples. An NSTec biologist was trained by Vicki Garcia, an associate of Dr. Conway, to band owls and collect the required samples.

Traps (Figure 6-15) were set out at 21 burrow sites between April 17 and July 11 for a total of 91 trap nights. A total of 34 owls, including 16 adults and 18 juveniles, was captured (Figure 6-16; Table 6-2). Three adult owls were recaptured later in the season. All owls, with the exception of one female that laid an egg in the trap, were banded with unique colored Acraft bands and aluminum FWS bands. Colored Acraft bands and FWS bands were placed on the left and right legs of adult females, respectively. For adult males, bands were reversed to facilitate identification of females and males in future years. All but two of the juveniles banded this year (no brown bands available) were banded with brown colored Acraft bands on their left legs and FWS bands on their right legs.

Feather and blood samples were taken from nearly all captured owls and will be analyzed at a future date by Dr. Conway and his colleagues. One adult female owl that was banded last year as a juvenile was captured again this year but at a different burrow site. The burrow sites are about $5.3 \mathrm{~km}(3.3 \mathrm{mi})$ apart. The female had a brood patch which suggests she was breeding. but it was not verified if she actually fledged young. Radioisotopic analysis of the feathers from this owl should provide information on where she spent the winter. Information learned from this cooperative effort will give NSTec biologists a greater understanding of western burrowing owl residency and migratory status on the NTS. It may also help determine where owls from the NTS are wintering and potential threats to them at their wintering areas, which may help explain any potential future declines of this species on the NTS. Trapping will continue over the next 1 to 2 years. 


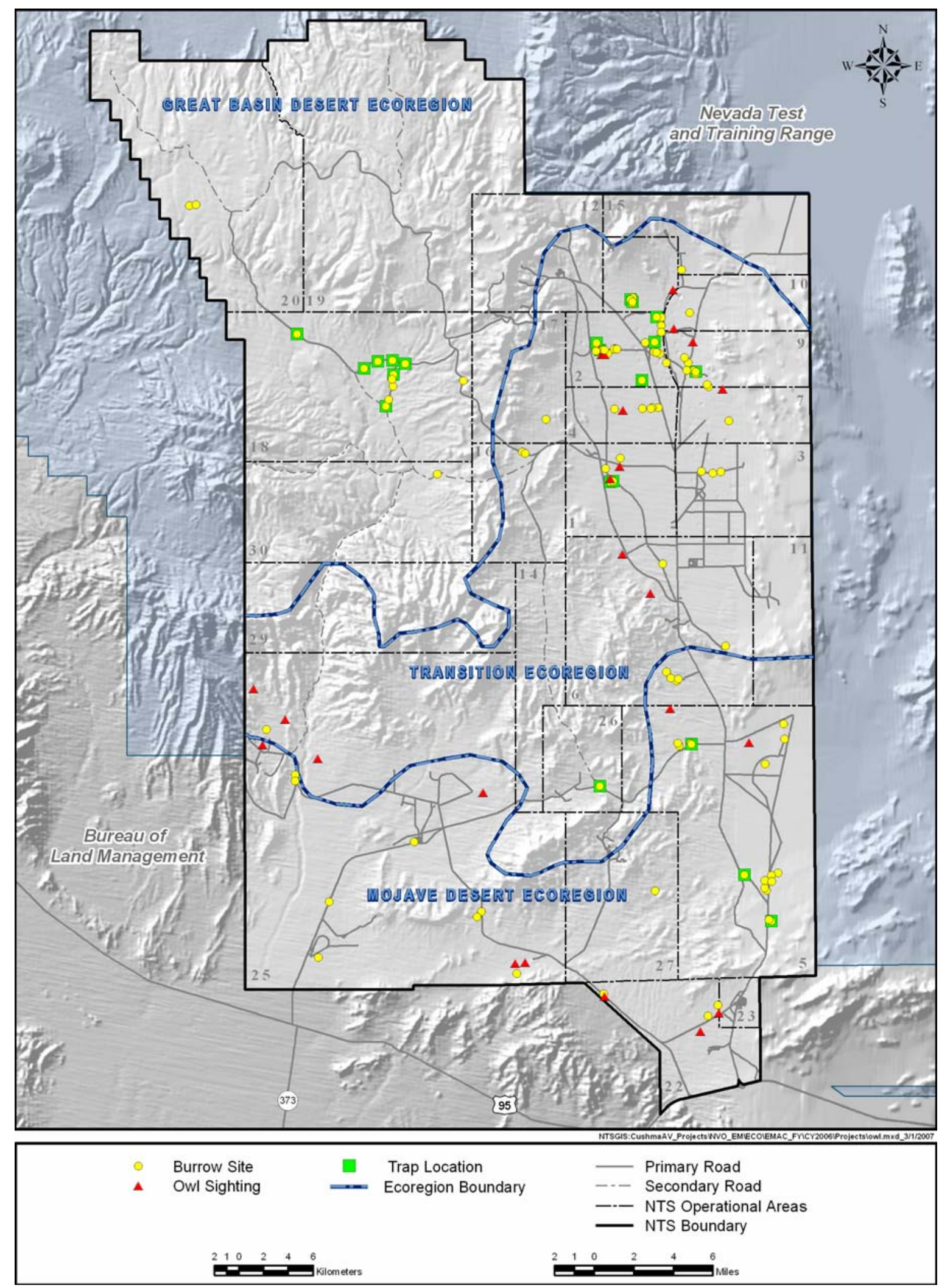

Figure 6-14. Known western burrowing owl distribution on the NTS and burrow sites where trapping occurred. 


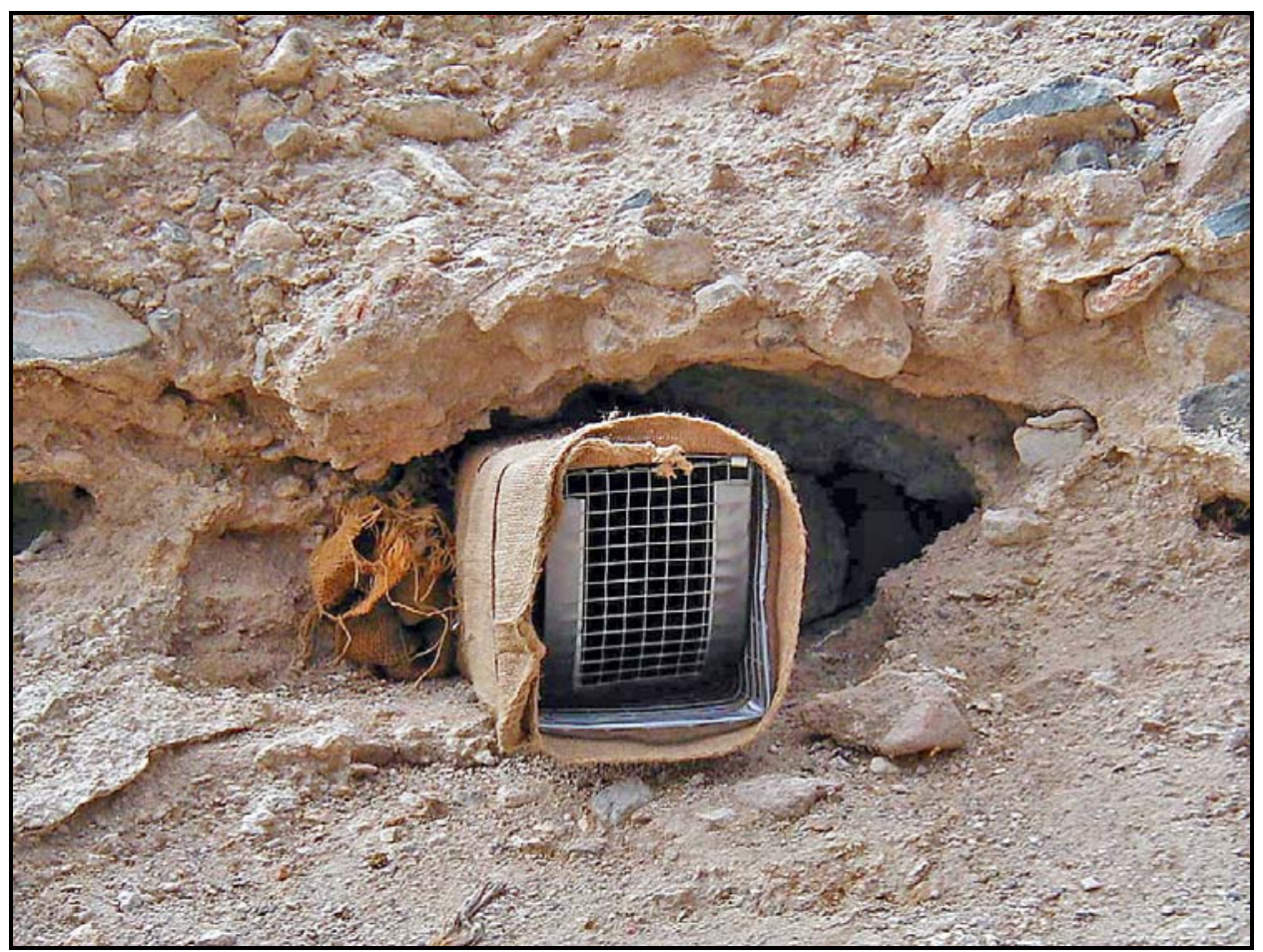

Figure 6-15. Two-way trap set at Burrow \#16, Area 18. (Photo by D. B. Hall, July 28, 2005)

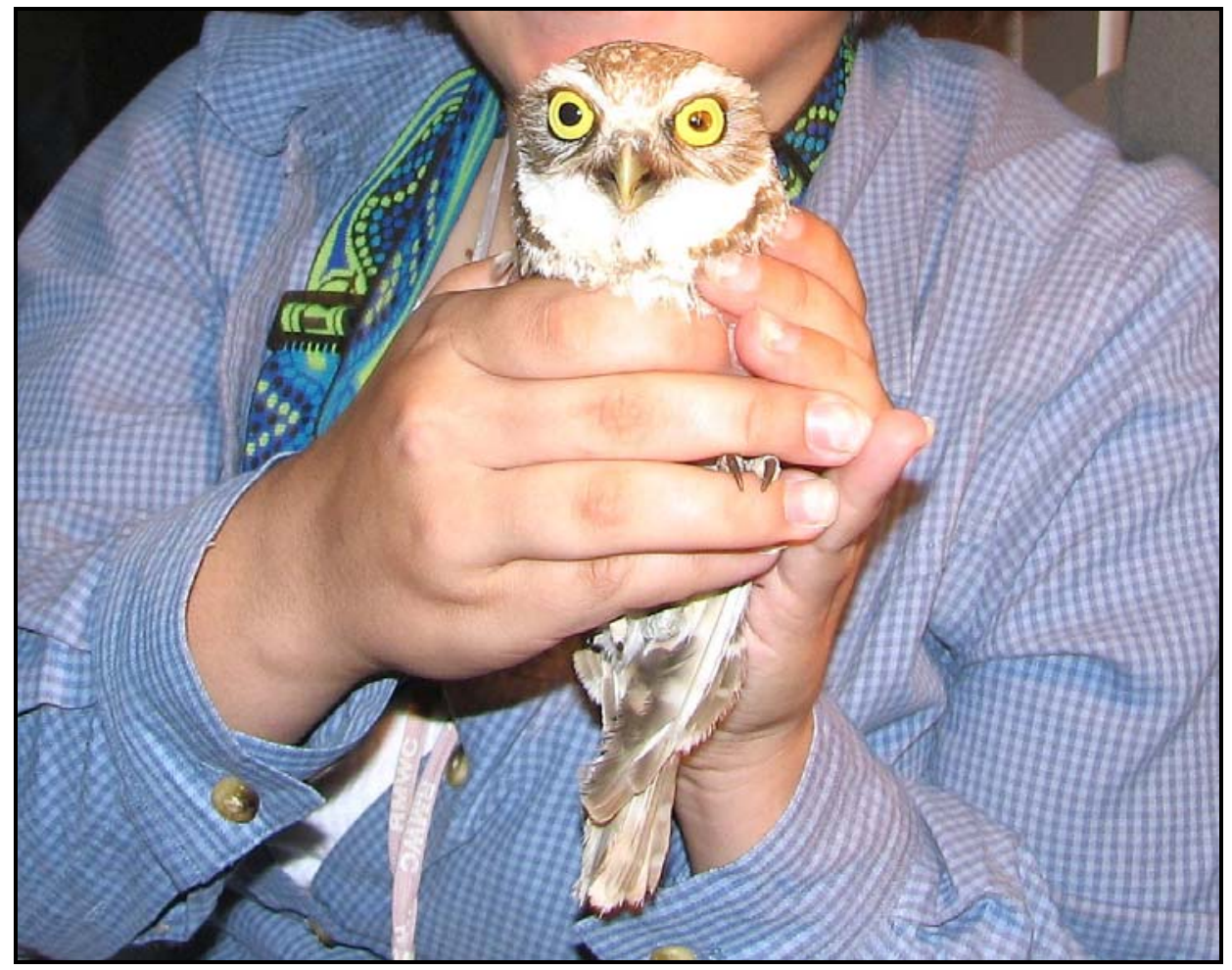

Figure 6-16. Captured western burrowing owl. (Photo by D. B. Hall, June 6, 2006) 
Table 6-2. Western burrowing owl trapping results on the NTS, April-July 2006.

\begin{tabular}{|c|c|c|c|c|c|c|c|c|}
\hline $\begin{array}{c}\text { Site } \\
\text { numberl } \\
\text { Burrow }\end{array}$ & Date & Sex* & $\begin{array}{l}\text { Weight } \\
\text { (grams) }\end{array}$ & $\begin{array}{c}\text { Juvenile } \\
\text { Age (days) }\end{array}$ & $\begin{array}{l}\text { Acraft } \\
\text { band \# }\end{array}$ & $\begin{array}{l}\text { USFWS } \\
\text { band \# }\end{array}$ & $\begin{array}{l}\text { Feathers } \\
\text { collecte } \\
\text { d }\end{array}$ & $\begin{array}{c}\text { Blood } \\
\text { collecte } \\
\text { d }\end{array}$ \\
\hline $32 / \mathrm{A}$ & $4 / 17$ & $\mathrm{~F}$ & 224 & Adultt* & Re-R3 & 934-26751 & Yes & Yes \\
\hline $38 / \mathrm{B}$ & $4 / 18$ & $M$ & 126 & Adult** & Re-S3 & 934-26798 & Yes & Yes \\
\hline $38 / \mathrm{B}$ & $4 / 18$ & $\mathrm{~F}$ & 154 & Adult & Re-U3 & 934-26799 & Yes & Yes \\
\hline $16 / \mathrm{A}$ & $4 / 18$ & $\mathrm{~F}$ & 202 & Adult & Re-V3 & 934-26752 & Yes & Yes \\
\hline $78 / \mathrm{A}$ & $4 / 18$ & $\mathrm{~F}$ & 211 & Adult** & Re-P3 & $934-26753$ & Yes & Yes \\
\hline $78 / \mathrm{A}$ & $4 / 18$ & $\mathrm{M}$ & 151 & Adult & Re-W3 & $934-26754$ & Yes & Yes \\
\hline $67 / \mathrm{A}$ & $4 / 19$ & $M$ & 147 & Adult & $\mathrm{Re}-\mathrm{X} 3$ & $934-26755$ & Yes & Yes \\
\hline $51 / \mathrm{A}$ & $4 / 19$ & $\mathrm{~F}$ & 227 & Adult & Re-U1 & $934-26756$ & Yes & Yes \\
\hline $79 / F$ & $4 / 19$ & $\mathrm{~F}$ & 202 & Adult & Re-V1 & 934-26757 & Yes & Yes \\
\hline $43 / \mathrm{B}$ & $4 / 24$ & $\mathrm{~F}$ & 220 & Adult & Re-W1 & 934-26758 & Yes & Yes \\
\hline $22 / D$ & $4 / 24$ & $\mathrm{~F}$ & & Adult & & & No & No \\
\hline $79 / E$ & $5 / 17$ & $\mathrm{~F}$ & 180 & Adult & Re-X1 & 934-26759 & Yes & Yes \\
\hline $67 / A$ & $5 / 17$ & $\mathrm{~F}$ & 187 & Adult & Re-Y1 & $934-26760$ & Yes & Yes \\
\hline $51 / \mathrm{A}$ & $5 / 17$ & $\mathrm{~F}$ & 173 & Adult & Re-Y3 & 934-26761 & Yes & Yes \\
\hline $16 / \mathrm{A}$ & $6 / 6$ & $\mathrm{~J}$ & 116 & 22 & BR-A5 & $934-26762$ & Yes & Yes \\
\hline $16 / \mathrm{A}$ & $6 / 6$ & $\mathrm{~J}$ & 109 & 22 & BR-B5 & $934-26763$ & Yes & Yes \\
\hline $16 / \mathrm{A}$ & $6 / 6$ & $\mathrm{~J}$ & 110 & 22 & BR-C5 & 934-26764 & Yes & Yes \\
\hline $64 / A$ & $6 / 12$ & $M$ & 145 & Adult & Re-DA & 934-26765 & Yes & Yes \\
\hline $64 / \mathrm{A}$ & $6 / 12$ & $\mathrm{~J}$ & 135 & 24 & BR-D5 & 934-26766 & Yes & Yes \\
\hline $64 / \mathrm{A}$ & $6 / 12$ & $\mathrm{~J}$ & 127 & 24 & BR-E5 & 934-26767 & Yes & Yes \\
\hline $64 / \mathrm{A}$ & $6 / 12$ & $\mathrm{~J}$ & 109 & 15 & BR-H5 & 934-26768 & No & No \\
\hline $64 / \mathrm{A}$ & $6 / 12$ & $\mathrm{~J}$ & 110 & 16 & BR-K5 & 934-26769 & No & No \\
\hline $64 / \mathrm{A}$ & $6 / 12$ & $\mathrm{~J}$ & 136 & 26 & BR-M5 & $934-26770$ & Yes & Yes \\
\hline $64 / \mathrm{A}$ & $6 / 12$ & $\mathrm{~J}$ & 125 & 24 & BR-P5 & 934-26771 & No & No \\
\hline $67 / \mathrm{A}$ & $6 / 12$ & $\mathrm{~F}$ & 174 & 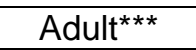 & Re-2S & $844-69927$ & Yes & No \\
\hline $64 / \mathrm{A}$ & $7 / 10$ & $\mathrm{~J}$ & 125 & $32-45$ & BR-R5 & 934-26772 & Yes & Yes \\
\hline 11/B & $7 / 11$ & $\mathrm{~J}$ & 115 & $32-45$ & BR-S5 & 934-26773 & Yes & Yes \\
\hline 11/B & $7 / 11$ & $\mathrm{~J}$ & 133 & $32-45$ & BR-U5 & $934-26774$ & Yes & Yes \\
\hline 11/B & $7 / 11$ & $\mathrm{~J}$ & 133 & $32-45$ & BR-V5 & 934-26775 & Yes & Yes \\
\hline $38 / \mathrm{B}$ & $7 / 11$ & $\mathrm{~J}$ & 119 & $32-45$ & BR-X5 & 934-26777 & Yes & Yes \\
\hline $38 / \mathrm{A}$ & $7 / 11$ & $\mathrm{~J}$ & 133 & $32-45$ & BR-W5 & $934-26776$ & Yes & Yes \\
\hline $78 / \mathrm{A}$ & $7 / 11$ & $\mathrm{~J}$ & 133 & $32-45$ & BR-Y5 & 934-26778 & Yes & Yes \\
\hline $78 / \mathrm{A}$ & $7 / 11$ & $\mathrm{~J}$ & 145 & $32-45$ & $\mathrm{Re}-\mathrm{DB}$ & 934-26779 & Yes & Yes \\
\hline $78 / \mathrm{A}$ & $7 / 11$ & $\mathrm{~J}$ & 125 & $32-45$ & Re-DC & $934-26780$ & Yes & Yes \\
\hline
\end{tabular}

$* \mathrm{~J}=$ juvenile, $\mathrm{F}=$ Female, $\mathrm{M}=$ Male; $* *$ Recapture same year; ***Recapture from previous year 


\subsection{Raptor Observations}

Several raptors occur and breed on the NTS. Some are sensitive species and all are protected/regulated under the Migratory Bird Treaty Act and/or Nevada State law. Raptors include all vultures, hawks, kites, eagles, ospreys, falcons, and owls. Because these birds occupy the higher trophic levels of the food chain, they are regarded as indicators of ecosystem stability and health. Including the western burrowing owl, there are nine raptors which are known to breed on the NTS.

Opportunistic sightings of raptors were common this year and included red-tailed hawks (Buteo jamaicensis), turkey vultures (Cathartes aura), golden eagles (Aquila chrysaetos), American kestrels (Falco sparverius). and prairie falcons (Falco mexicanus). Many of these individuals are commonly seen perching on utility poles on Frenchman and Yucca Flat. Barn owls (Tyto alba) were a common occurrence in buildings on the NTS this year and several were relocated to Las Vegas for treatment of injuries. A new species of hawk, the common blackhawk (Buteogallus anthracinus) was observed flying near the Mercury Highway on Yucca Flat (Area 4) on April 4, 2006, by a NSTec biologist. This species breeds in central and southern Arizona and New Mexico and has been observed casually in Utah. It is the first known record for this area. Cooper's hawk (Accipiter cooperii) and red-tailed hawks have been observed around water sources near Rainier Mesa.

Bird Mortality-Bird mortality is recorded as a measure of potential impacts that NNSA/NSO activities may have on protected bird species (Table 6-3). Only five bird mortalities and six injured raptors were recorded in 2006. Two of the primary causes of bird mortality were road kill and electrocution. Six injured birds were captured and taken to the North Las Vegas animal hospital for examination. Birds were cared for by the Wild Wing Project, Inc., in Las Vegas, operated by Lisa Ross. Five of the six injured raptors were rehabilitated and released back into the wild (Table 6-3). Without the Wild Wing Project, Inc., these individuals would have died. The status of the other wounded raptor, a prairie falcon, is not known. Overall impacts to raptor populations from NNSA/NSO activities at the NTS appear to be very low.

Table 6-3. Records of bird mortality and injuries on the NTS during 2006.

\begin{tabular}{|c|c|c|c|c|}
\hline \multirow[b]{2}{*}{ Species } & \multicolumn{3}{|c|}{ Cause of Death } & \multirow{2}{*}{ Injured $^{\mathrm{a}}$} \\
\hline & Electrocution & Roadkill & Unknown & \\
\hline Barn owl (Tyto alba) & \multirow{7}{*}{2} & \multirow{7}{*}{$\begin{array}{l}1 \\
1\end{array}$} & \multirow{7}{*}{1} & \multirow[t]{3}{*}{3} \\
\hline Golden eagle (Aquila chrysaetos) & & & & \\
\hline Long-eared owl (Asio otus) & & & & \\
\hline Prairie falcon (Falco mexicanus) & & & & 1 \\
\hline Red-tailed hawk (Buteo jamaicensis) & & & & 2 \\
\hline Roadrunner (Geococcyx californianus) & & & & \\
\hline Turkey Vulture (Cathartes aura) & & & & \\
\hline Total: & 2 & 2 & 1 & 6 \\
\hline
\end{tabular}

${ }^{\mathrm{a}}$ Injured birds were transported to Las Vegas, Nevada, for treatment 


\subsection{Small Mammal Surveys}

Small mammal surveys were conducted to provide information on species distribution on the NTS. The objectives were to (a) investigate potential new habitats for the dark kangaroo mouse (Microdipodops megacephalus) and the pale kangaroo mouse (M. pallidus), (b) collect data on small mammals that could fill spatial data gaps needed for a better understanding of species distribution on the NTS, (c) learn more about species preferences for fine-grained microhabitats on NTS, and (d) compare species composition at historic sites to current data.

Sampling per site was conducted by setting baited traplines of 100 Sherman live traps for three consecutive nights. Traplines were opened and baited between 3 and $6 \mathrm{pm}$ and checked the following morning between $6-10 \mathrm{am}$. Animals were identified and marked with a unique indelible color on each day (excluding the last day) so total numbers of individuals could be tallied. At most locations, two comparison traplines were set in parallel micro-habitats, such as a wash and an upland habitat. The first two sites (Lower Fortymile Wash/upland) were sampled for six nights to evaluate benefits from trapping six as opposed to three nights. Diurnally, active species (e.g., squirrels) were excluded from statistical analysis because the trapping effort focused on the capture of nocturnal rodents, not diurnal species.

At two sites, Whiterock Spring and Tippipah Spring, funnel traps (reptiles) were set in close proximity to mammal traps because of narrowness of the habitat. There may have been some trap interference that could have affected mammal trap success or total individuals caught. Results from mammals captured in reptile traps at Camp 17 Pond and the above sites are also discussed. A Z-test was used to test for differences in total numbers of individuals caught between each matched microhabitat pair. Chi-square tests were also performed across similar microhabitat pairs to determine if species proportions varied significantly between sites. Cell totals $(<5)$ were lumped into an "other species category" before conducting tests. Exclusive of paired comparisons, no statistical comparisons were made for species across sites. Sites varied greatly in characteristics. Trapping occurred over a wide geographic area and time span (April-October). Statistical significance was set at $\mathrm{P}=0.05$ for all tests.

A total of 2,965 captures was recorded representing 14 species across 23 sites on the NTS (Figure 6-17). A total of 1,555 individual nocturnal small mammals, representing 12 species. was caught (Table 6-4). Trap success averaged 36.7 percent and varied from 15.0 to 71.6 percent across sites.

Significant differences were found in total numbers of individuals captured at four of 10 sites (Z-test, Table 6-4). At those four sites, the wash site had higher numbers than the upland sites. Significant differences in species composition were found in most microhabitat comparisons of wash and upland. Nine out of ten paired sites had significant differences in species composition (Table 6-4). Tippipah Spring versus the nearby upland was the only matched pair comparison that was not statistically different (Table 6-4). This may be due to the narrowness and variability along the spring habitat trapped (1-8 $\mathrm{m}$ ). Upland animals appeared to spill over into the narrow riparian habitat which affects species composition (Figure 6-18). 




Figure 6-17. Trapping locations for small mammals on the NTS in 2006. 
Table 6-4. Numbers of individual small mammals captured on traplines on the NTS in $2006^{a}$. $\mathbf{P}=$ presence, but numbers excluded from analysis.

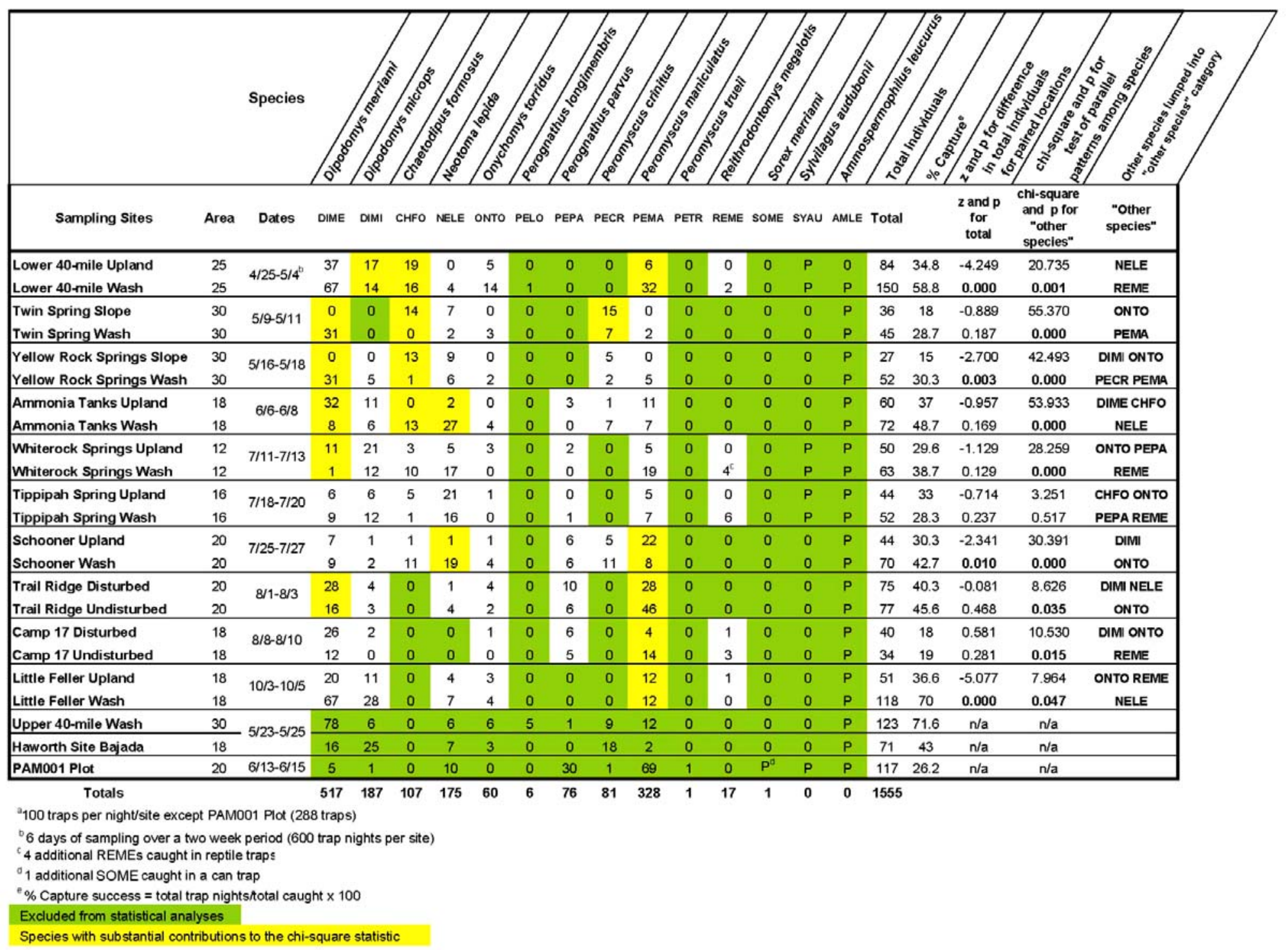




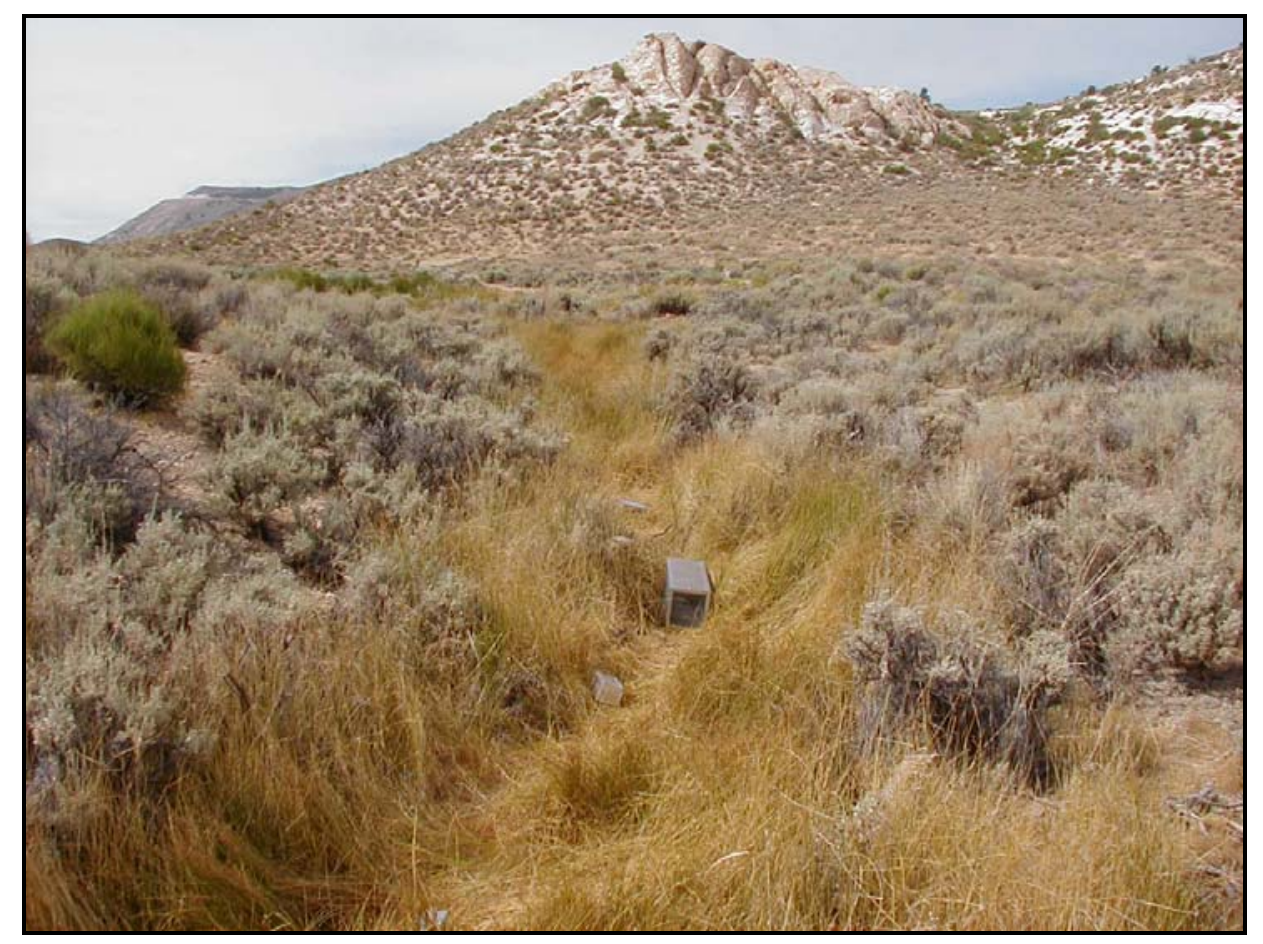

Figure 6-18. View of Tippipah Spring showing narrowness of habitat sampled for mammals and reptiles. (Photo by P. D. Greger, July 19, 2006)

The canyon mouse (Peromyscus crinitus), and long-tailed pocket mouse, (Chaetodipus formosus) were considerably more abundant at Twin Spring slope (rocky) than the Twin Spring wash (non-rocky) $\left(\chi^{2}=55.4, p=0.000\right)$. Similarly, the long tailed pocket mouse, and the desert woodrat (Neotoma lepida), were more abundant around rocky outcrops and rocky washes than uplands lacking rocks $\left(\chi^{2}=53.9\right.$, $\mathrm{p}=.000)$ (Ammonia Tanks wash versus the upland). Another species, the western harvest mouse (Reithrodontomys megalotis) (Figure 6-19), was much more abundant at aquatic sites (Whiterock Spring, Tippipah Spring, and Camp 17 Pond) than at sites without water. Over a 2-week period, there were 8, 9, and 12 captures of this species at these 3 locations, respectively. These are the highest numbers of captures for the western harvest mouse ever recorded on the NTS.

Six washes had higher numbers of Merriam's kangaroo rat (Dipodomys merriami), the most abundant species recorded in 2006, than on the corresponding upland site. Qualitatively, Merriam's kangaroo rat was more abundant in wider sandy washes (Little Feller, Twin Spring, Yellow Rock Spring, and Lower Fortymile Wash) as opposed to narrow rocky washes (Ammonia Tanks wash) or other rocky habitats. Deer mice (Peromyscus maniculatus) were the second most abundant animal caught in this study and were found in a variety of habitats from washes in southern NTS (Area 25) to uplands in the northern regions (Area 20). 


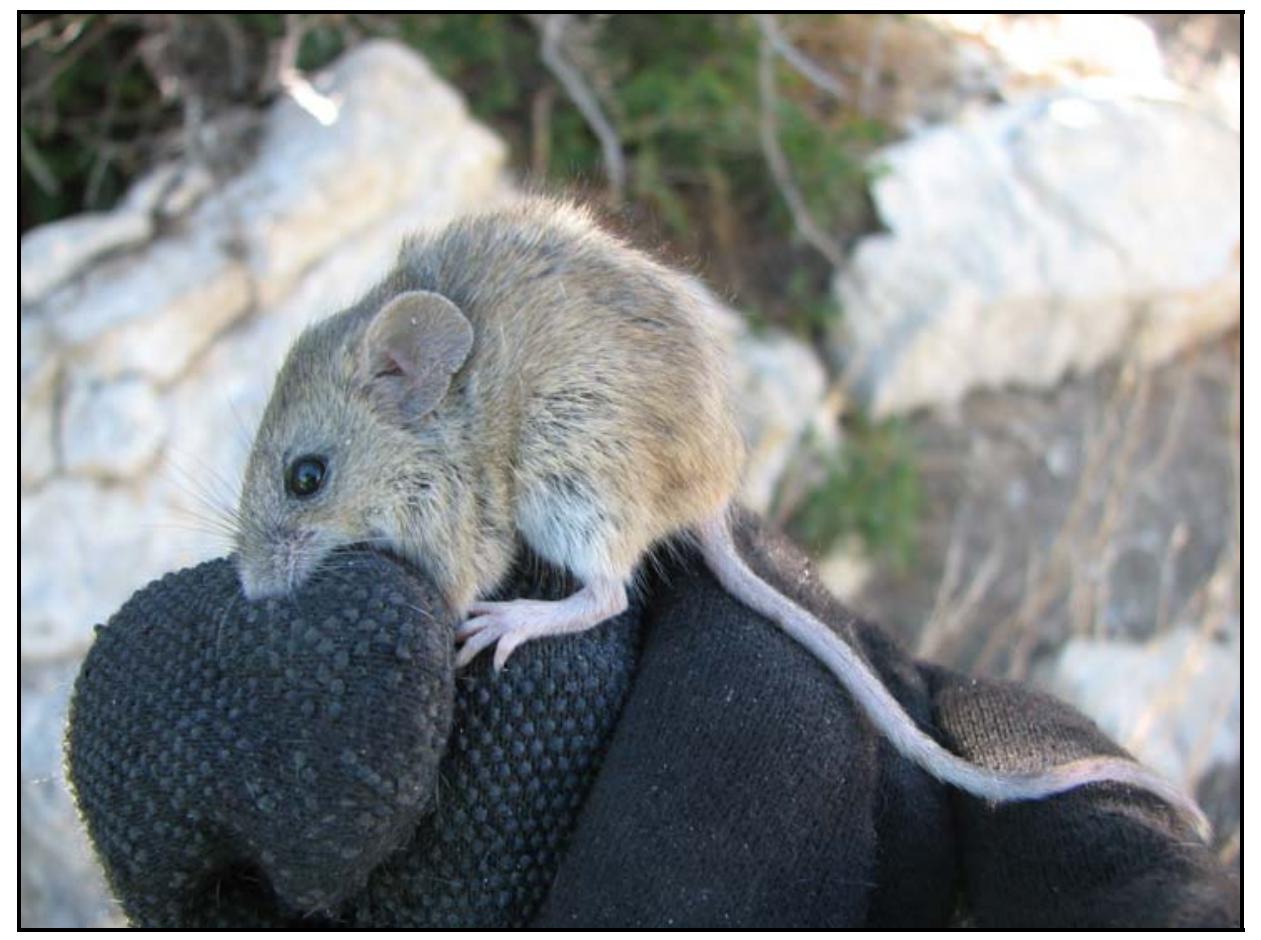

Figure 6-19. Western harvest mouse captured at Whiterock Spring showing long tail. (Photo by D. B. Hall, August 7, 2006)

Trapping six nights at the first two sites (Table 6.4 as shown previously) indicated no increased benefit as to additional species caught. However, on the fourth night, a moderate number of new animals were caught to add to the 3-day total. For example, on the fourth trap night, 28.5 and 24.5 percent more new individuals were caught at the Forty,ile upland and wash sites, respectively. This suggests a slight benefit for trapping a fourth night at a site, or the increase in new individuals may have been due to a 3-day break from trapping between the third and fourth night.

One historical ecological plot, PAM001, in Area 20 was sampled this year for the first time since 1992. One hundred eighteen individuals were trapped and there were 226 captures over three days in 2006 compared to 87 individuals and 165 captures in 1992, suggesting a higher relative density in 2006 (Hunter 1994). This site was dominated by deer mice in 2006 with a species composition of 59.0 percent, slightly higher than the deer mice abundance in 1992 (43.7 percent). The abundance of Great Basin pocket mouse (Perognathus parvus) (Figure 6-20) was similar in 1992 (25.6 percent) compared to 2006 (27.6 percent). However, the cactus mouse was captured in 1992, but none in 2006. In addition, Merriam's kangaroo rat was present in small numbers in 2006, but not in 1992. Also, of note for 2006 is the capture of a Merriam's shrew (Sorex merriami) using can traps (Table 6-4). Capture success was slightly higher in 2006 (26.2 percent) compared to 1992 (19.2 percent).

At Trail Ridge, there was a significant difference $\left(\chi^{2}=8.62 ; \mathrm{P}=0.035\right)$ in species composition between the paired traplines, natural shrub versus disturbed (Table 6-4). The disturbed vegetation was initially altered by the Palanquin 5KT blast of April 14, 1965. The major contribution to the statistical difference in species composition can be attributed to the abundance of Merriam's kangaroo rat on the disturbed area and an abundance of deer mice on the natural vegetation. 


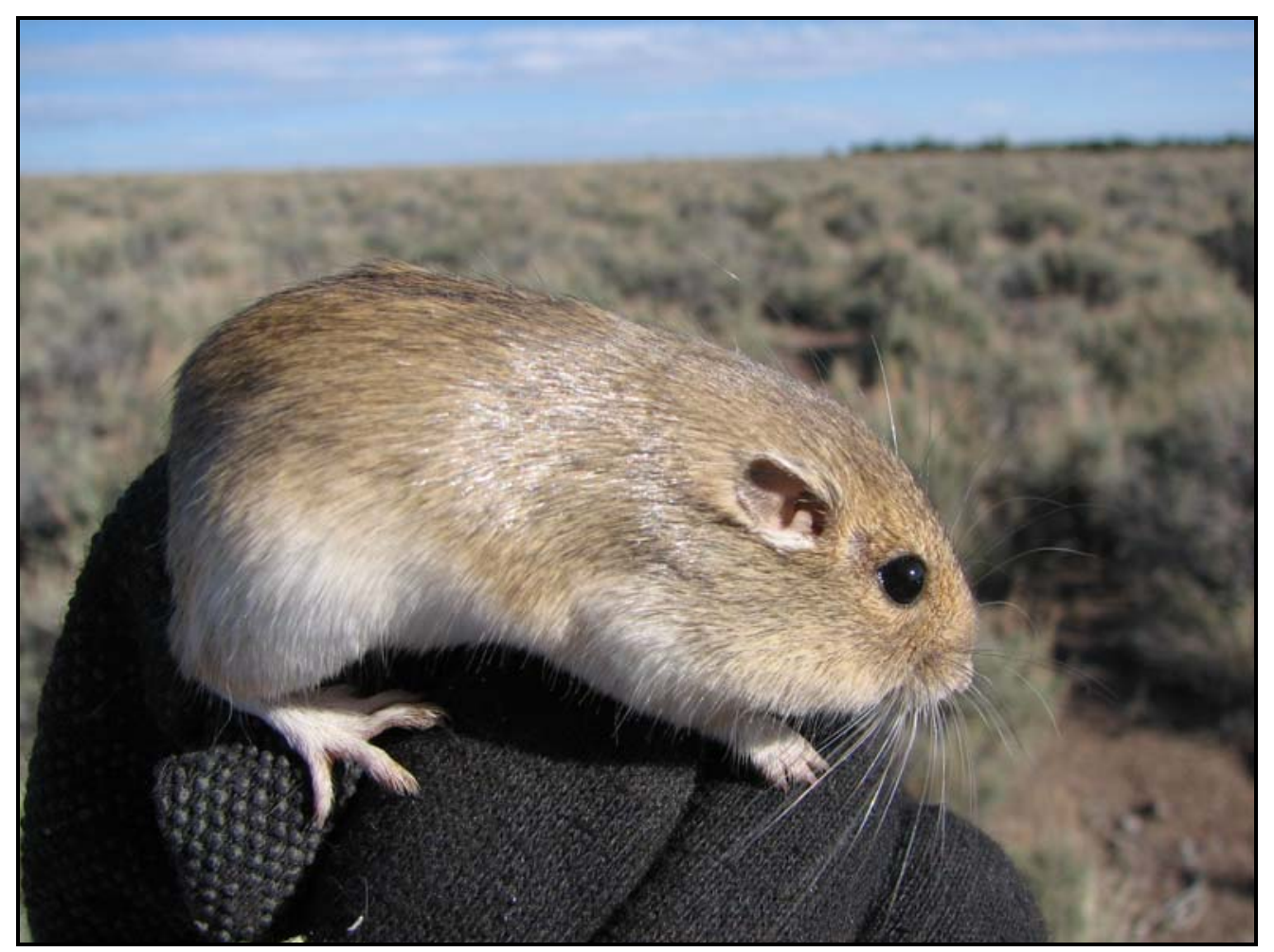

Figure 6-20. Great Basin pocket mouse at PAM001 plot in Area 20 showing silky pelage. (Photo by D. B. Hall, June 19, 2006)

Species abundance of small mammals on the Trail Ridge undisturbed and disturbed traplines (August 2006), was qualitatively compared to Trapline C shrub and fallout sampled areas from May 1980 to June 1982 (O'Farrell and Sauls, 1985) to examine changes in rodent abundance over time (Table 6-5). The main difference was 16 captures on undisturbed and 28 captures on disturbed of Merriam's kangaroo rat in 2006 (21-36 percent on natural and fallout) when none were caught from 1981-83 on Trapline C. The most abundant species, deer mice, was very similar in composition in 2006 (61.3 percent) compared to $1980-82$ (69.5 percent) on natural areas (Table 6-5).

Species composition on the fallout area has changed over time from an abundant population of deer mice and Great Basin mice with no Merriam's kangaroo rats in 1980-1982 to a high abundance of Merriam's kangaroo rats with a lesser percentage of deer mice and Great Basin mice in 2006. These results, however, should be viewed with caution as trap effort (e.g., number trap/nights) was lower in 2006 (Table 6-5). 
Table 6-5. Total numbers of individual small mammals captured at Trail Ridge from May 1980 to June 1982 compared to total individuals caught at EMAC traplines in August 2006.

\begin{tabular}{|c|c|c|c|c|c|c|c|c|}
\hline \multirow[b]{3}{*}{ Species } & \multicolumn{4}{|c|}{ EG\&G Trapline $\mathbf{C}^{\mathbf{a}}$} & \multicolumn{4}{|c|}{ EMAC Traplines $^{b}$} \\
\hline & \multicolumn{2}{|c|}{$\begin{array}{l}\text { Natural } \\
\text { Shrubs }\end{array}$} & \multicolumn{2}{|c|}{$\begin{array}{l}\text { Fallout } \\
\text { Area }\end{array}$} & \multicolumn{2}{|c|}{$\begin{array}{l}\text { Natural } \\
\text { Shrubs }\end{array}$} & \multicolumn{2}{|c|}{$\begin{array}{c}\text { Fallout } \\
\text { Area }\end{array}$} \\
\hline & No. & $\%$ & No. & $\%$ & No. & $\%$ & No. & $\%$ \\
\hline $\begin{array}{l}\text { Peromyscus maniculatus } \\
\text { Deer mouse }\end{array}$ & 105 & 69.5 & 102 & 63.3 & 46 & 59.7 & 28 & 37.3 \\
\hline $\begin{array}{l}\text { Perognathus longimembris } \\
\text { Little pocket mouse }\end{array}$ & 0 & 0 & 1 & 0.6 & 0 & 0 & 0 & 0 \\
\hline $\begin{array}{l}\text { Perognathus parvus } \\
\text { Great Basin pocket mouse }\end{array}$ & 27 & 17.8 & 35 & 21.7 & 6 & 7.8 & 10 & 13.3 \\
\hline $\begin{array}{l}\text { Dipodomys merriami } \\
\text { Merriam's kangaroo rat }\end{array}$ & 0 & 0 & 0 & 0 & 16 & 20.8 & 28 & 37.3 \\
\hline $\begin{array}{l}\text { Dipodomys microps } \\
\text { Chisel-toothed kangaroo rat }\end{array}$ & 8 & 5.3 & 7 & 4.3 & 3 & 3.9 & 4 & 5.3 \\
\hline $\begin{array}{l}\text { Dipodomys ordii } \\
\text { Ord kangaroo rat }\end{array}$ & 0 & 0 & 1 & 0.6 & 0 & 0 & 0 & 0 \\
\hline $\begin{array}{l}\text { Onychomys torridus } \\
\text { Southern grasshopper mouse }\end{array}$ & 4 & 2.6 & 1 & 0.6 & 2 & 2.6 & 4 & 5.3 \\
\hline $\begin{array}{l}\text { Peromyscus trueii } \\
\text { Pinyon mouse }\end{array}$ & 7 & 4.6 & 14 & 8.7 & 0 & 0 & 0 & 0 \\
\hline $\begin{array}{r}\text { Neotoma lepida } \\
\text { Desert packrat }\end{array}$ & 0 & 0 & 0 & 0 & 4 & 5.2 & 1 & 1.3 \\
\hline $\begin{array}{l}\text { Ammospermophilus leucurus } \\
\text { White-tailed antelope squirrel }\end{array}$ & $P$ & & $P$ & & $P$ & & $P$ & \\
\hline Trap/nights & 1,195 & & 1,104 & & 300 & & 300 & \\
\hline Total & 151 & & 161 & & 77 & & 75 & \\
\hline \multicolumn{9}{|c|}{$\begin{array}{l}{ }^{b} \text { EMAC traplines were perpendicular to, and bracketed by, Trapline. The center point of the Fallout } \\
\text { Line was located at E 542183, N 4127736, NAD 1983; the center point of the Shrub Line was located } \\
\text { at E 542051, N 4128210, NAD 1983. }\end{array}$} \\
\hline \multicolumn{9}{|c|}{$\mathrm{P}=$ Presence of species, individuals not enumerated. } \\
\hline${ }^{\mathrm{c}}$ Ammospermophilus numbers e & fron & cent & culati & . & ses. & & & \\
\hline
\end{tabular}




\subsection{Bat Surveys}

In 2006, bat monitoring focused on: (a) sampling known maternity roosts to determine occupancy patterns and compare techniques for counting bats, (b) conducting pre-closure surveys at the $\mathrm{N}$ and $\mathrm{T}$ Tunnel Complexes to determine if gating is necessary, (c) passive acoustic monitoring of bat activity at Camp 17 Pond, and (d) responding to numerous calls to remove bats, especially a rabid bats, and documenting their roost sites.

\subsubsection{Maternity Roost Surveys}

Population trend data for most bat species are lacking (Ellison et al., 2003). One accepted technique used to census bats entails counting the number of bats exiting from maternity roost sites two to 3 weeks before parturition. This is reportedly the time when the maternity colony population is most stable (Pierson et al., 1999). Another technique includes going inside the roosts and counting the number of roosting bats either during the summer at maternity roosts or during the winter at hibernacula. Although effective, this technique will not be used on the NTS for the following two reasons: (a) entering abandoned mines can be very risky and poses serious safety concerns; and (b) some bat species, including the Townsend's big-eared bat (Corynorhinus townsendii), are very sensitive to roost disturbance and may abandon the roost and their young if disturbed.

At least two maternity colonies are known on the NTS (BN, 2003; 2005). These include aggregations composed primarily of Townsend's big-eared bat (Figure 6-21) and fringed myotis (Myotis thysanodes) (Figure 6-22). Roost use is very complex and bats may move among several roost sites during the summer breeding season (Sherwin et al., 2000; 2003). Work was conducted this summer to gather data to help develop a protocol for long-term population monitoring of maternity roosts on the NTS. The two main objectives were to determine occupancy patterns of known maternity roosts and compare two different cameras to determine which one works the best to count bats.

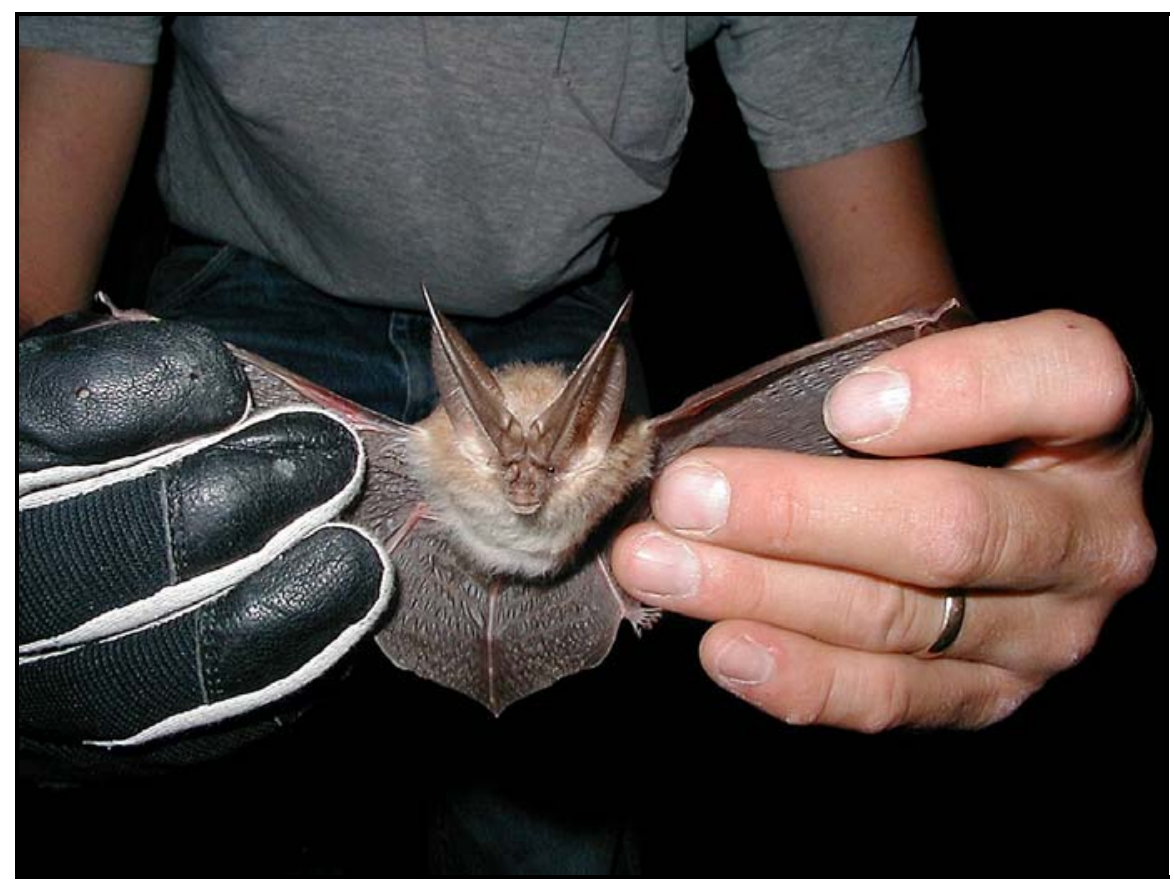

Figure 6-21. Townsend's big-eared bat. (Photo by W. K. Ostler, August 25, 2003) 


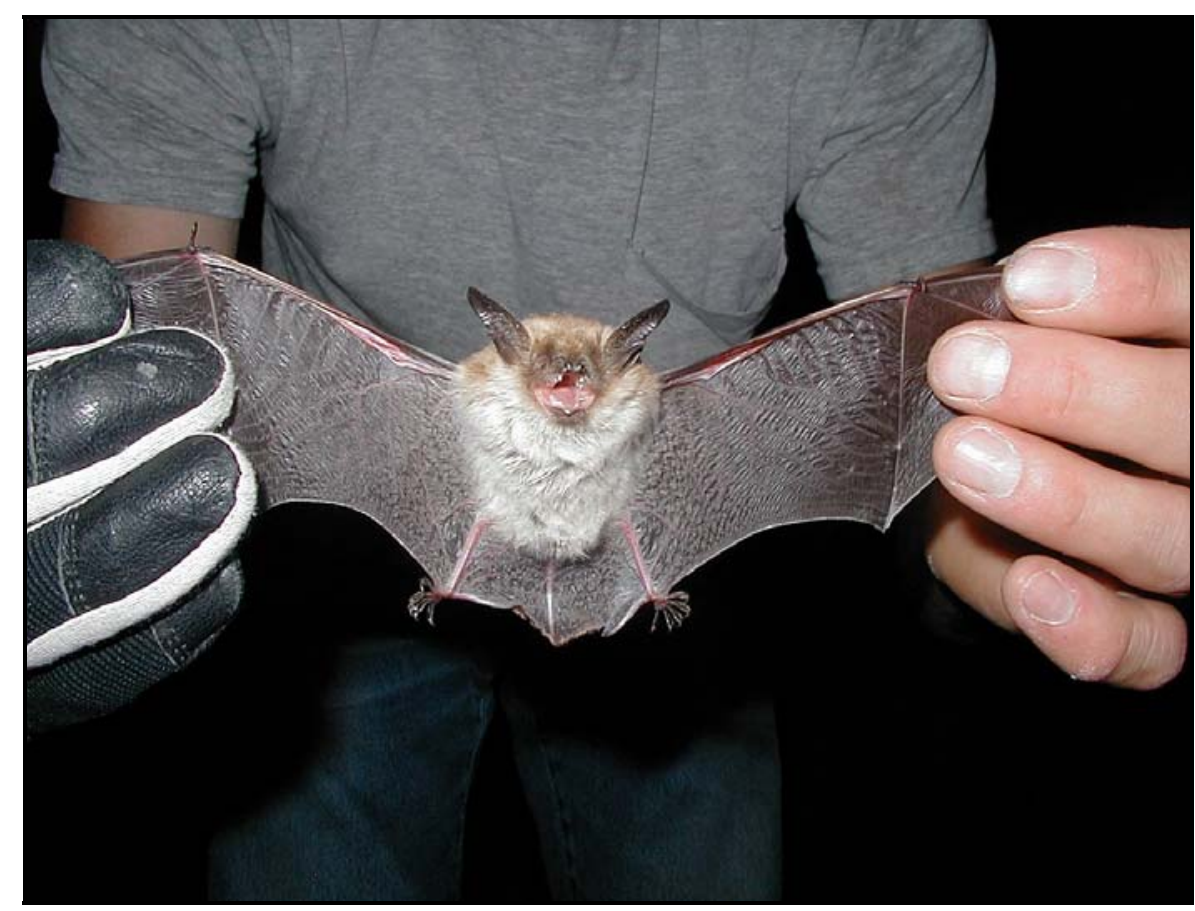

Figure 6-22. Fringed myotis. (Photo by W. K. Ostler, August 25, 2003)

Sampling was conducted at four roost sites; namely, Twin Spring Adit, Climax Mine Adit1, Oak Spring Middle Basin Adit1 (OSMid1), and Oak Spring Middle Basin Adit2 (OSMid2) (Figure 6-23) between May $1^{\text {st }}$ and July $20^{\text {th }}$. Exit surveys at OSMid2 were conducted using night vision goggles with no acoustic recordings, and a mist net was set up on May $23^{\text {rd }}$. Sampling at the other three sites during the first week of May was designed to (a) see if bats were using the roost; (b) capture bats using mistnets near the roost entrance to determine what species were present, their gender, and reproductive status (e.g., pregnant or lactating); and (c) count the number of bats exiting the roost.

Sampling during the latter part of May and mid July was done to determine if bats were using the roost and compare the number of bats counted using two different cameras recording simultaneously. The two cameras used were a Sony ${ }^{\circledR}$ nightshot camera (DCR-HC42 NTSC) with a portable Sony ${ }^{\circledR}$ infrared light source (HVL-IRM) and a Raytheon NightSight ${ }^{\mathrm{TM}}$ camera (PalmIR 250) hooked to a Sony ${ }^{\circledR}$ analog video camera (CCD-TR940) for recording purposes. Some researchers can identify certain bats to species as they fly out of the roost using the nightshot camera with infrared light whereas the NightSight ${ }^{\mathrm{TM}}$ camera uses thermal imaging which allows for better contrast between the bats and the surrounding habitat.

Cameras recorded bat activity for 1.5 hours after the first bat was seen around the roost entrance which was generally shortly after sunset. Mini DV tapes used in the Sony camera only hold 1.5 hours worth of video. Cameras were set to begin recording and end at the same time for direct comparison. Tapes were reviewed and the number of exits and entries were tallied. Bat behavior during evening outflights involves bats exiting the roost and bats entering the roost. Often bats will exit the roost, fly around briefly, and fly right back into the roost, making counting difficult. 


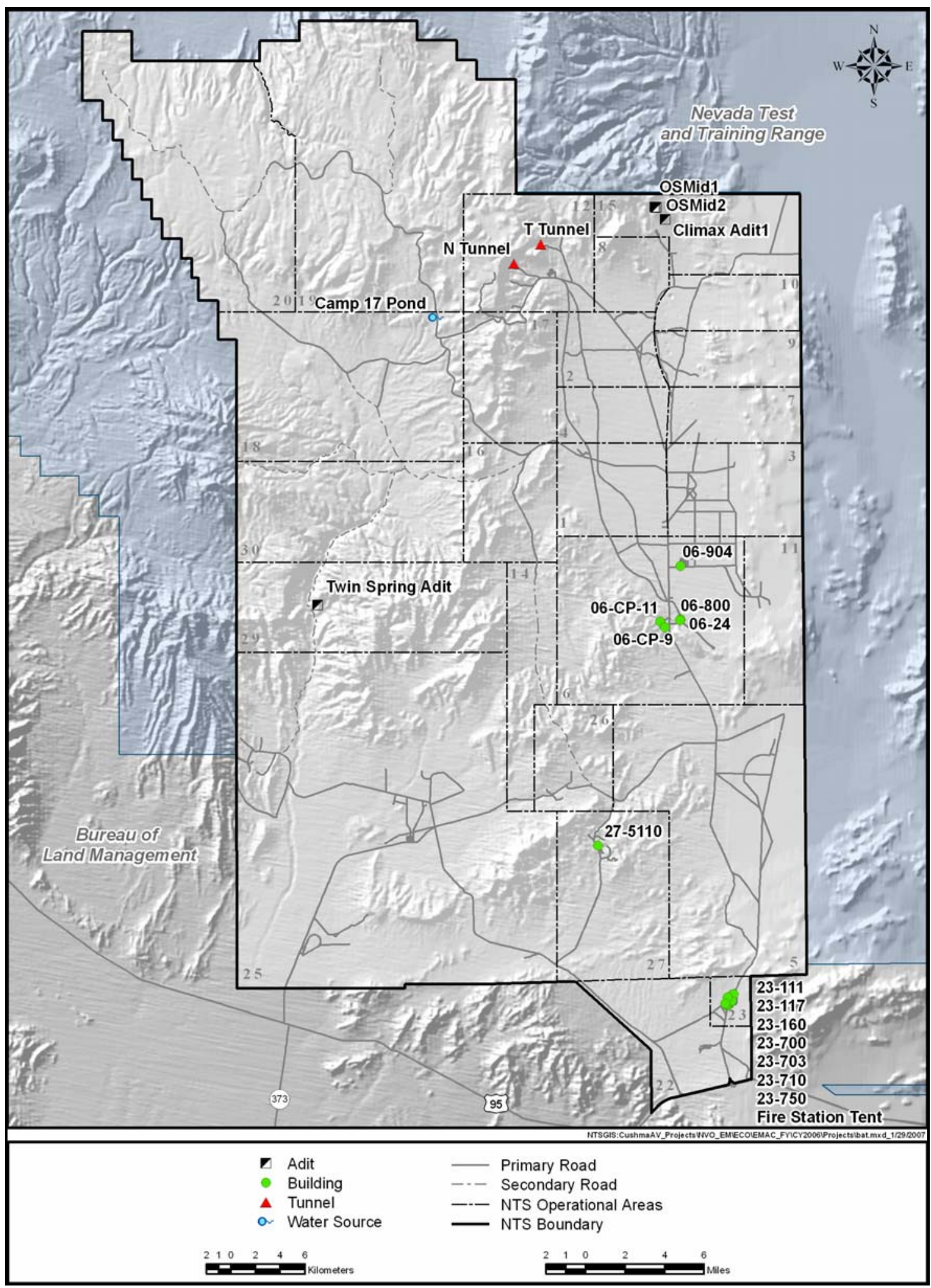

Figure 6-23. Sites monitored for bat activity during 2006 including adits sampled for maternity colony population trends, tunnels sampled for bat use before closure, and buildings where nuisance bats were removed. 
Typically, bats exhibiting the latter behavior were not counted. The number of entries was subtracted from the number of exits for a net exit or entry count. If more bats exited the roost within an hour after sunset. it was assumed to be a day roost. If more bats entered the roost within an hour after sunset, it was assumed to be a night roost/foraging site. In some cases, a roost could be both a day roost and a night roost/foraging site.

Because female bats had been previously captured at each roost, sites designated as day roosts were assumed to be maternity roosts. Acoustic monitoring was also conducted at each site using the Anabat II system concurrent with video recording. Acoustic files were analyzed and identified to species under contract by Dr. Michael J. O'Farrell (O’Farrell Biological Consulting).

Results from Twin Spring Adit indicate bat activity from May to July. with a substantial decrease in activity by mid July (Table 6-6). It appears that the maternity colony, or most of it, moves to a different site during June or July. Females of both Townsend's big-eared bats and fringed myotis were caught at Twin Spring Adit on May 1, 2006, and did not appear to be pregnant or lactating. Pregnant and lactating Townsend's big-eared bats and fringed myotis were captured at this site on June 2, 2004 (BN, 2005). Acoustically, the site was dominated by fringed myotis and Townsend's big-eared bat with some California myotis (M. californicus), western pipistrelle (Pipistrellus hesperus), and Brazilian free-tailed bat (Tadarida brasiliensis) calls detected also (Table 6-6). It is not known if the latter three species actually used the roost or just flew over the roost and were detected by the Anabat II system. Based on the acoustic and capture data. it was assumed that the bats counted at the roost were fringed myotis or Townsend's big-eared bat. This site should be monitored for long-term population trends during the first three weeks of May.

Data from Climax Mine Adit1, OSMid1, and OSMid2 reveal a complex pattern of occupancy (Table 6-6). Based on the close proximity of these three sites, it is believed that the bats using these sites are part of one maternity colony (Hall to Sherwin, 2006). Results suggest movement among roosts with most of the activity at Climax Mine Adit1 during early May, shifting to OSMid1 during late May, and shifting back to Climax Adit 1 during mid July, albeit at reduced numbers. Townsend's big-eared bat was the only species captured at both Climax Adit1 and OSMid2. Bats captured at Climax Mine Adit1 in early May did not appear to be pregnant or lactating whereas one bat captured at OSMid2 in late May appeared to be pregnant. Acoustically, calls of fringed myotis and Townsend's big-eared bat dominated Climax Mine Adit1 and OSMid1. Other species detected acoustically were small-footed myotis (M. ciliolabrum), California myotis, pallid bat (Antrozous pallidus), and western pipistrelle (Table 6-6). It is not known if these other species used the roost or just flew over the roost, but based on the acoustic and capture data, it was assumed that the bats counted at the roosts were fringed myotis or Townsend's big-eared bat. These sites should be sampled next year to see if the same pattern is evident.

Counts from the two types of cameras showed varying results (Table 6-6). In only a few instances it was possible to see the big ears of Townsend's big-eared bat with the use of the Sony® Nightshot camera. Perhaps with more infrared lights it would have made species identification easier, but only with species having prominent features such as big-eared bats or free-tailed bats. It was much easier counting bats exiting or entering the roost using images from the NightSight ${ }^{\mathrm{TM}}$ camera because the contrast between the bats and the surrounding habitat was much better than the contrast in the images from the nightshot camera. Based on these results, it is recommended that the NightSight ${ }^{\mathrm{TM}}$ camera be used for long-term population trend monitoring in the future. 
Table 6-6. Results of maternity roost monitoring and $\mathrm{N}$ and $\mathrm{T}$ Tunnel monitoring including camera results and capture and acoustic data.

\begin{tabular}{|c|c|c|c|c|c|c|c|c|c|c|c|}
\hline & \multicolumn{2}{|l|}{ Location } & 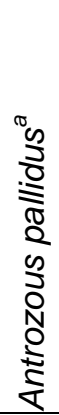 & 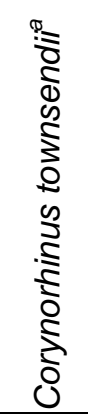 & 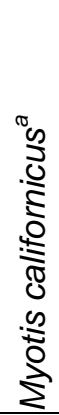 & 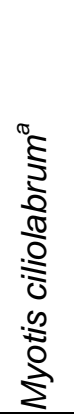 & $\begin{array}{l}0 \\
.0 \\
0 \\
0 \\
0 \\
0 \\
0 \\
\Sigma\end{array}$ & 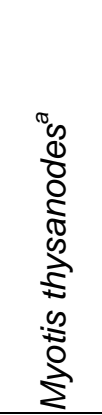 & 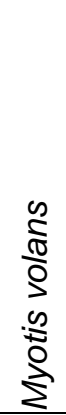 & 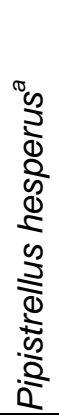 & 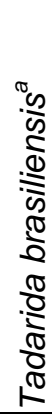 \\
\hline \multicolumn{12}{|c|}{ Twin Spring Adit } \\
\hline Date & Sony & NightSight & & & & & & & & & \\
\hline 05/01/2006 & 87 out (109 out, 22 in) & Not sampled & & $\begin{array}{c}11 F \\
11\end{array}$ & 9 & & & $\begin{array}{l}7 F \\
49\end{array}$ & & & \\
\hline 05/30/2006 & 139 out (170 out, 31 in) & 169 out (197 out, 28 in) & & 19 & & & & 36 & & 1 & 1 \\
\hline 07/17/2006 & 5 out (21 out, 16 in) & 2 out (18 out, 16 in) & & 7 & 1 & & & 1 & & 1 & \\
\hline \multicolumn{12}{|c|}{ Climax Mine Adit1 } \\
\hline & Sony & NightSight & & & & & & & & & \\
\hline & & & & $9 F$ & & & & & & & \\
\hline $\begin{array}{l}05 / 02 / 2006 \\
05 / 24 / 2006\end{array}$ & $\begin{array}{l}84 \text { out ( } 134 \text { out, } 50 \text { in) } \\
2 \text { out ( } 53 \text { out, } 51 \text { in) }\end{array}$ & $\begin{array}{c}\text { Not sampled } \\
2 \text { in (56 out. } 58 \text { in) }\end{array}$ & 1 & $\begin{array}{c}15 \\
3\end{array}$ & 2 & 3 & & $\begin{array}{c}0,19 \\
10\end{array}$ & & & \\
\hline $07 / 20 / 2006$ & 19 out (211 out, 192 in) & 15 out (200 out, 185 in) & 1 & 4 & 2 & 1 & & 19 & & 1 & \\
\hline \multicolumn{12}{|c|}{ OSMid1 } \\
\hline & Sony & NightSight & & & & & & & & & \\
\hline 05/03/2006 & 4 in (7 out, 11 in) & Not sampled & & 0 & 3 & 1 & & 0,4 & & & 1 \\
\hline 05/22/2006 & No IR light & 129 out (195 out, 66 in) & & 14 & & 12 & & 1 & & & \\
\hline 05/23/2006 & 133 out (167 out, 34 in) & 113 out (173 out, 60 in) & & 5 & 1 & 1 & & & & 1 & \\
\hline 07/19/2006 & 4 in (23 out, 27 in) & 3 out (30 out, 27 in) & 3 & & 4 & & & 4 & & & \\
\hline
\end{tabular}




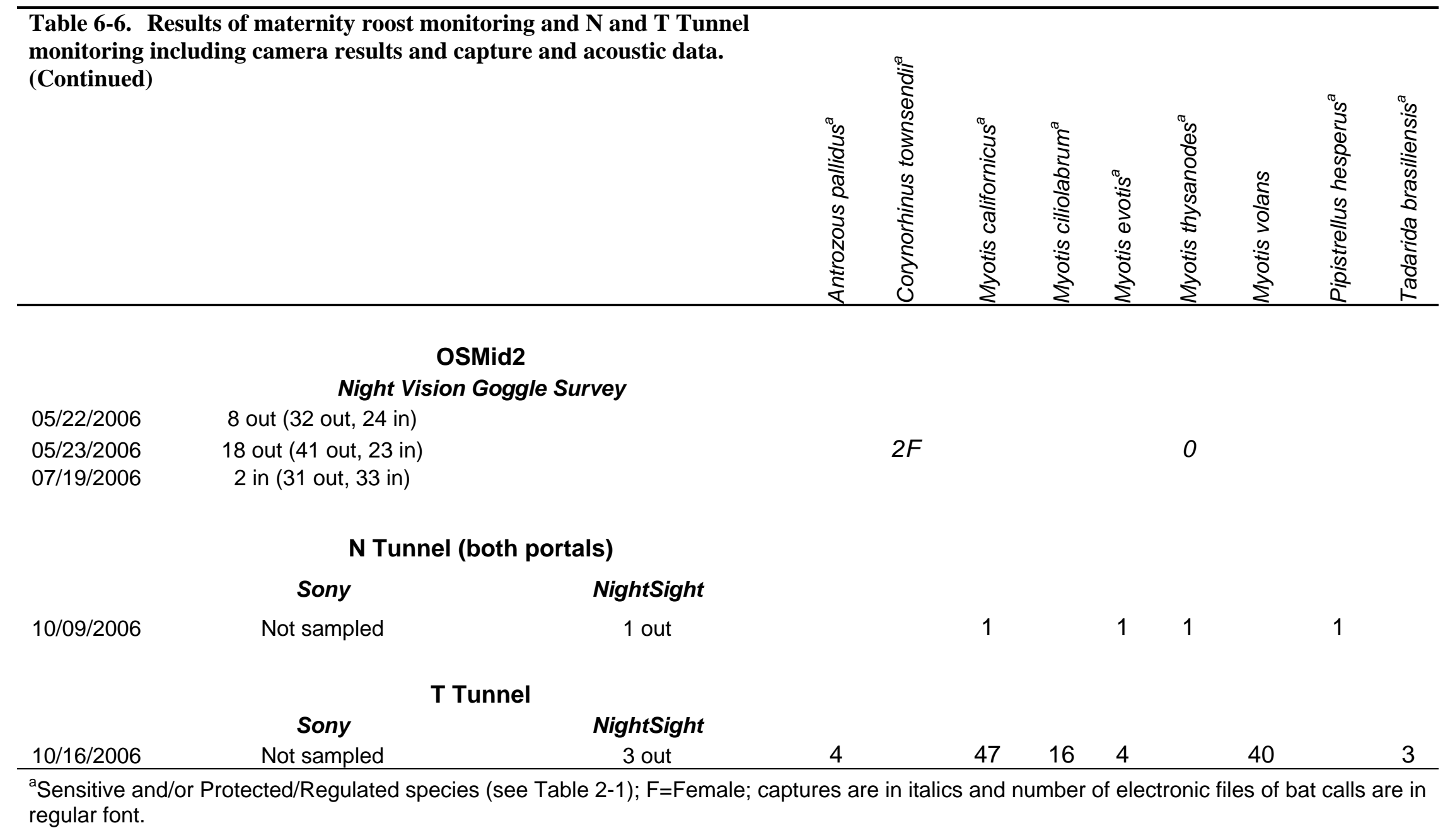




\subsubsection{N and T Tunnel Pre-closure Surveys}

NSTec biologists learned in September that two portals at N Tunnel and one portal at T Tunnel were going to be closed during the fall of 2006/winter 2007. These tunnels had previously been monitored for bat use with bat activity documented at both tunnel complexes (BN, 1999; 2000; 2006; Hall, 2000). Exit surveys were conducted at N Tunnel portals on October $9^{\text {th }}$ and at $\mathrm{T}$ Tunnel on October $16^{\text {th }}$ to determine if bats were still using these sites. An internal survey at $\mathrm{N}$ Tunnel was also conducted on October $9^{\text {th }}$ and did not show any sign of bat use, although it was impossible to see and inspect all the surfaces inside the tunnel for bat use. Exit survey results indicated that bats were using both portals at $\mathrm{N}$ Tunnel and the one portal at $\mathrm{T}$ Tunnel with more activity at $\mathrm{T}$ Tunnel, although only a few bats were observed exiting or entering either tunnel. Because $\mathrm{N}$ Tunnel has multiple openings and there are several suitable roosts (i.e., IJK Tunnel Complex) in close proximity to T Tunnel, it was recommended that a bat-compatible gate be installed in the two portals at N Tunnel but not at T Tunnel. An NSTec biologist met with Defense Threat Reduction Agency personnel and designed a closure gate that would meet their closure requirements and still allow access for bats (Tuttle and Taylor, 1998) without negatively impacting project schedule or cost. Future monitoring at N Tunnel will investigate the gate's impact on bats using this site.

\subsubsection{Passive Acoustic Monitoring System}

In order to learn more about long-term bat activity over different seasons and years, a passive acoustic monitoring system was installed at Camp 17 Pond (Figure 6-24) on September 22, 2003. Tens of thousands of electronic files containing bat calls have been recorded and are in the process of being analyzed by O'Farrell Biological Consulting. Due to faulty batteries, a lot of data for spring and summer was lost. The system would only work for a couple of hours after sunset. This incident confirms the importance of downloading data as soon after collection as

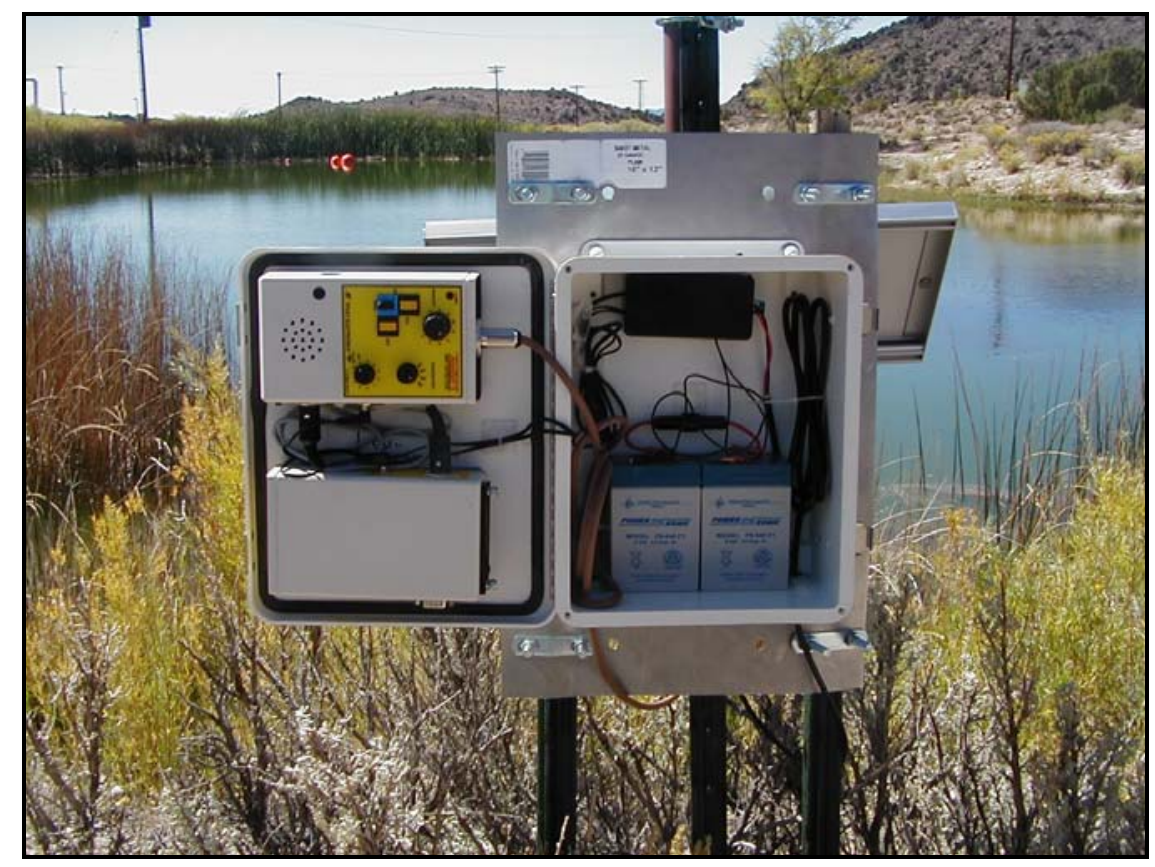

Figure 6-24. Passive acoustic monitoring system at Camp 17 Pond. (Photo by D. B. Hall, September 23, 2003) 
possible and checking the data for completeness. Last year, Robert Peppard an NSTec Senior Scientist, developed the BAT Loader utility to more easily summarize the large amounts of data. This past year he developed another utility that takes weather data collected from dataloggers and manipulates these to correspond with data from the acoustic files. This allows for correlations to be made between bat activity and different climatic parameters such as temperature, wind speed, barometric pressure, humidity, etc. Future work will focus on developing these correlations, continuing to collect new data, and analyzing files.

\subsubsection{Bats In Buildings}

Every year, NSTec biologists get calls from people that encounter bats roosting in various places, some welcome and some not so welcome. This year was no exception. In fact, biologists responded to more nuisance bat calls this year than in any other previous year, including a bat that tested positive for rabies in Area 27. It was a juvenile, male, western pipistrelle. To our knowledge, this is the first bat found on the NTS that has ever tested positive for rabies. It flew around a worker, who struck the bat in self defense, and the bat later died. It was collected and taken to a veterinarian who submitted it for testing. A News Flash announcement went out to all employees warning them to notify biologists if they encountered a bat in an unwanted place. This may be the reason we had more nuisance bat calls than in previous years. Only about 0.5 1.0 percent of bats carry the rabies virus, and they do not exhibit the "wild dog" syndrome and attack people. Usually they get sick, withdraw into a quiet, dark place, and die (Hall to O'Farrell, 2006).

Twenty-three bats (including 8 dead) were found on 19 occasions at 15 buildings ( 9 in Mercury, 5 in Area 6, and 1 in Area 27) (Figure 6-23, shown previously). Ten bats were western pipistrelles, five were pallid bats, one was either California or small-footed myotis, and seven were unknown species. Roost site locations will continue to be documented and stored in the EGIS faunal database to enable NSTec biologists to increase their knowledge about bat roosting sites on the NTS.

\subsection{Wild Horse Surveys}

Horse monitoring provides information on the abundance, recruitment (i.e., survival of horses to reproductive age), and distribution of the horse population on the NTS. Monitoring of individual horses at NTS began in 1989. In 2006, NSTec biologists determined horse abundance and recorded horse sign along roads. Also, selected natural and human-made water sources were visited in the summer to determine their influence on horse distribution and movements and document the impact horses are having on NTS wetlands and water sources. Information on abundance and recruitment during 1990-1998 is summarized in Greger and Romney (1999).

\subsubsection{Abundance Survey}

A count of individual horses is used to estimate abundance. In 2006 a count of horses was conducted during 10 non-consecutive days between April and December. A standard road course was driven to locate and identify horses. Motion cameras at Camp 17 pond and other locations were used to photograph horses. Individuals were identified by their unique physical markings (facial blazes), and classified as foal, yearling, or older. The direct population count in 2006 was 53 individuals not including foals (Table 6-7). Seven horse bands (composed of stallions, subordinate males, females, and their offspring) were detected this year. Bands observed ranged 
Table 6-7. Number of horses observed on the NTS by age class, gender, and year.

\begin{tabular}{|c|c|c|c|c|c|c|c|c|c|c|c|c|c|c|c|c|}
\hline \multirow[b]{2}{*}{ Age Class } & \multicolumn{16}{|c|}{ Years } \\
\hline & \multicolumn{2}{|c|}{1999} & \multicolumn{2}{|c|}{2000} & \multicolumn{2}{|c|}{2001} & \multicolumn{2}{|c|}{2002} & \multicolumn{2}{|c|}{2003} & \multicolumn{2}{|c|}{2004} & \multicolumn{2}{|c|}{2005} & \multicolumn{2}{|c|}{2006} \\
\hline Foals & \multicolumn{2}{|c|}{5} & \multicolumn{2}{|c|}{11} & \multicolumn{2}{|c|}{11} & \multicolumn{2}{|c|}{5} & \multicolumn{2}{|c|}{6} & \multicolumn{2}{|c|}{5} & \multicolumn{2}{|c|}{5} & \multicolumn{2}{|c|}{8} \\
\hline Yearlings & \multicolumn{2}{|c|}{2} & & & \multicolumn{2}{|c|}{2} & & & \multicolumn{2}{|c|}{$9^{a}$} & & & \multicolumn{2}{|c|}{6} & \multicolumn{2}{|c|}{8} \\
\hline \multirow[b]{2}{*}{ Age Class } & \multicolumn{16}{|c|}{ Gender $^{b}$} \\
\hline & $M$ & $F$ & $M$ & $\mathbf{F}$ & $M$ & $F$ & M & $F$ & M & $\mathbf{F}$ & M & $\mathbf{F}$ & $\mathbf{M}$ & $\mathbf{F}$ & M & $\mathbf{F}$ \\
\hline 2-Year Olds & 0 & 0 & $2^{c}$ & 0 & 2 & 2 & 0 & 2 & 0 & 0 & 4 & 4 & 5 & 4 & 3 & 3 \\
\hline 3-Year Olds & 0 & 0 & 0 & 0 & 0 & 0 & 2 & 2 & 0 & 2 & 0 & 0 & 4 & 4 & 4 & 4 \\
\hline $\begin{array}{l}\text { Adults } \\
\text { (>3-Year } \\
\text { Olds) }\end{array}$ & 11 & 20 & 13 & 21 & 11 & 20 & 8 & 19 & 8 & 20 & 6 & 21 & 5 & 21 & 7 & 24 \\
\hline $\begin{array}{r}\text { Total: } \\
\text { (excluding } \\
\text { foalsand } \\
\text { dead horses) }\end{array}$ & & & & & & & & & & & & & & & & \\
\hline
\end{tabular}

${ }^{a}=1$ of the 9 was found dead; ${ }^{b} M=$ Male, $F=$ Female; ${ }^{c}=2$ were found dead

in size from 3 to 14 individuals, excluding foals. Eight foals were observed with their mares from June to December. The population showed a moderate increase in numbers over last year, due to the recent survival of younger aged horses (yearling to two-year olds).

\subsubsection{Horse Population Trends and Predation}

Recent trends in the NTS horse population indicate a clear recovery in numbers from a low of about 30 individuals in 1999 to about 53 in 2006 (Figure 6-25).

This may be related to ample moisture during this time and possibly reduced predation pressure from mountain lions. Spotlighting counts in fall of 2006 indicate that deer numbers are increasing greatly over previous counts during 1999-2000 on the NTS. Thus, if more deer are available as prey to lions and other carnivores, this may explain increased survival of young horses as predation pressure may be spread out across a more numerous prey base. Prey switching has been suggested for a population of cougars in the Montgomery Peaks area of Nevada, where high numbers of deer seasonally shifted lion predation away from horses to deer (Turner et al., 1991). 


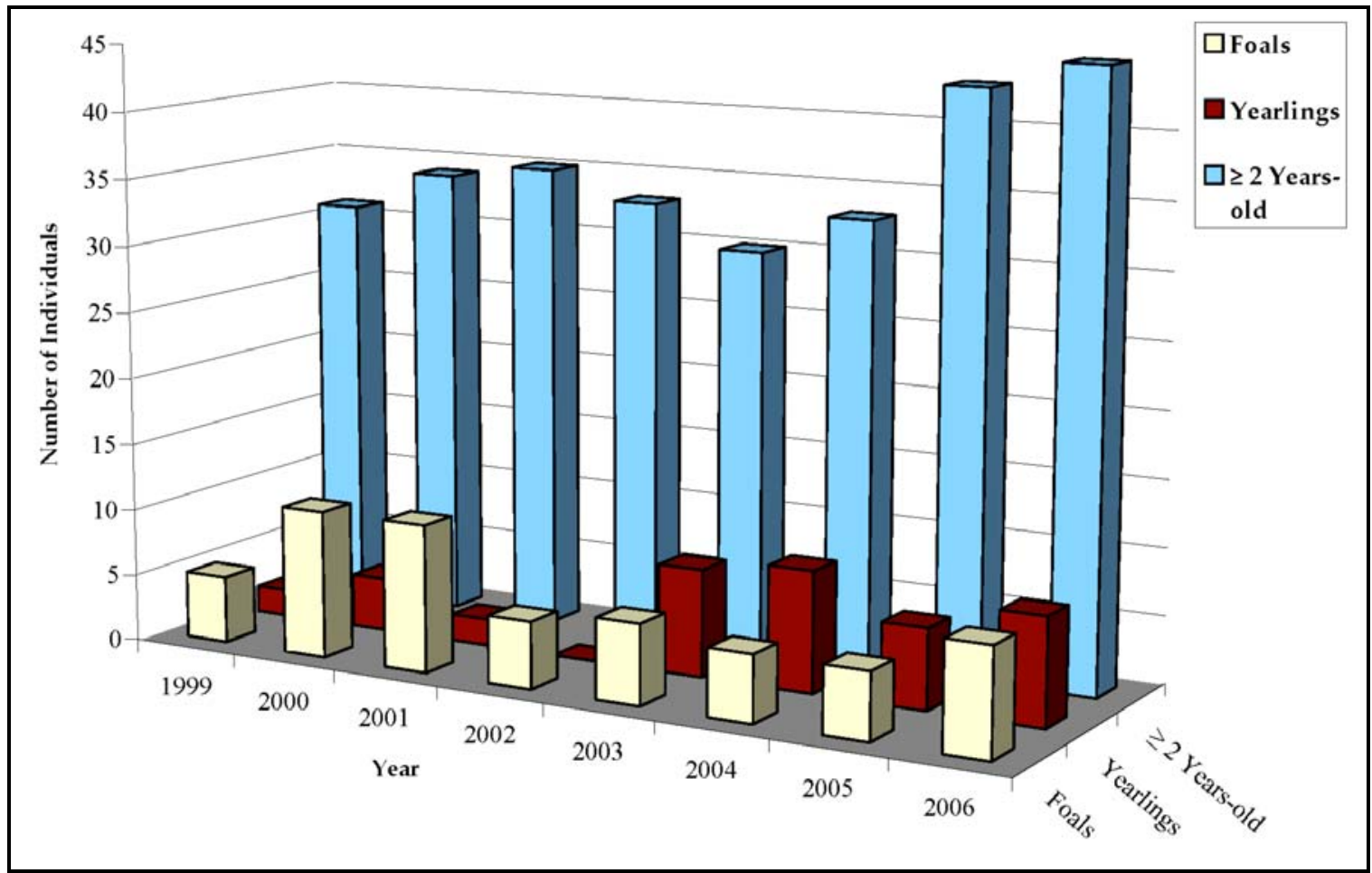

Figure 6-25. Trends in the age structure of the horse population from 1999 to 2006.

\subsubsection{Annual Range Survey}

During 2006, selected roads were driven within and along the boundaries of the suspected annual horse range and all fresh sign (estimated to be $<1$ year old) located on and adjacent to the roads were recorded. Eight days of effort were expended for the road surveys. Horse sign data collected during the road surveys and horse use at natural and human-made water sources indicate that the 2006 NTS horse range (Figure 6-26) includes Gold Meadows, Yucca Flat, Eleana Range, southwest foothills of the Eleana Range, and the Echo Peak region of southeast Pahute Mesa.

Overall, the annual horse range appears to be similar to previous years but possibly smaller due to less use of habitats east of the Eleana Range. This year, use of Captain Jack Spring by horses also seemed much reduced, suggesting that some horses moved away from the Eleana Range during summer to fall. 


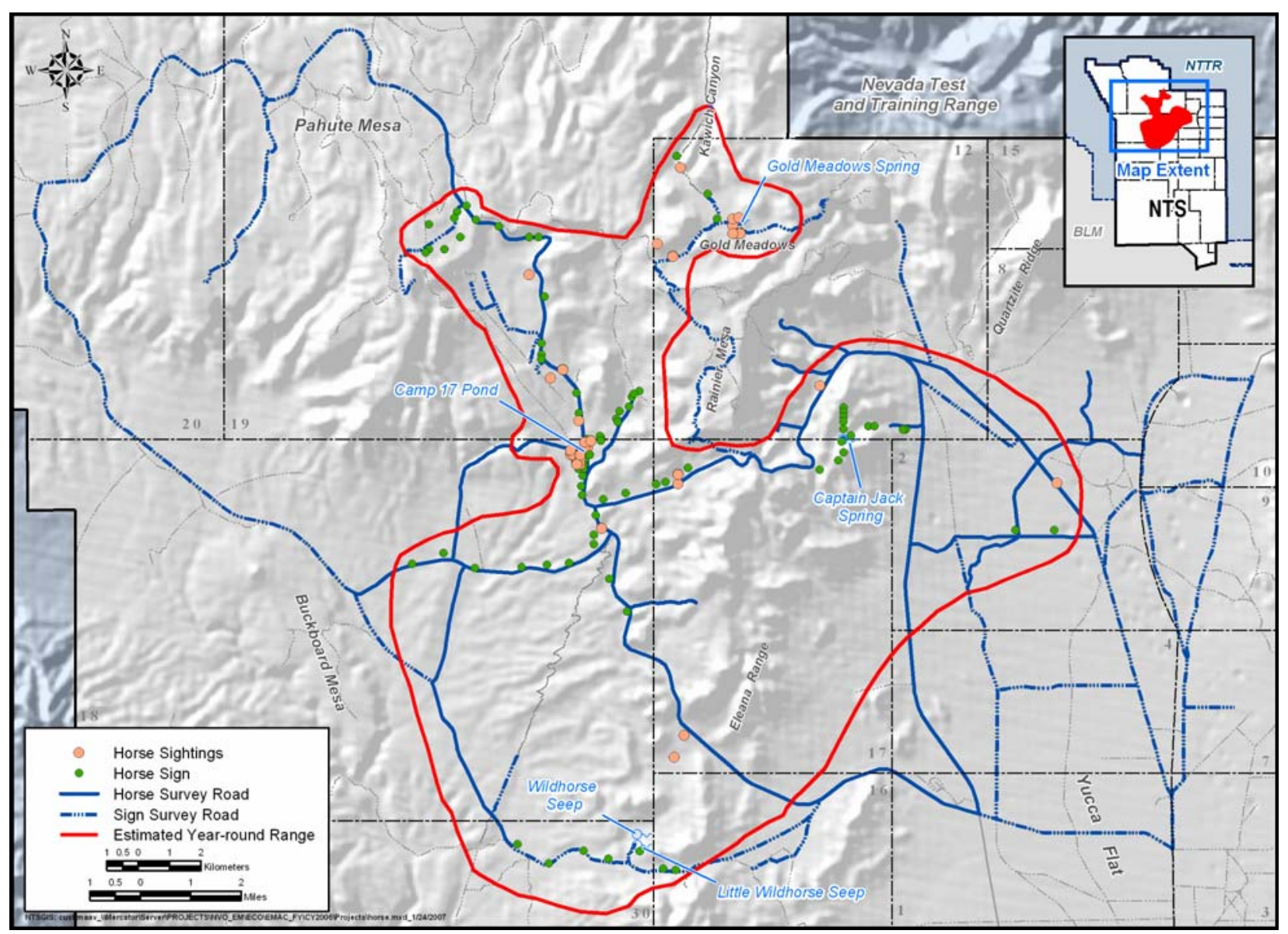

Figure 6-26. Feral horse sightings and horse sign observed on the NTS during 2006.

\subsubsection{Horse Use of NTS Water Sources}

The NTS horse population is dependent on several natural and human-made water sources in Areas 18, 12, and 30 during different seasons (Figure 6-26). Human-made water source availability has not changed greatly over the last eight years. One natural water source (Gold Meadows Spring in Area 12) and one human-made pond (Camp 17 Pond in Area 18) were used heavily as in past years. Camp 17 Pond and Gold Meadows Spring were the most important summer-fall water sources for horses based on the observed heavy activity. Horses often use ephemeral water sources in winter such as rock tanks and natural pools that collect water from rain and snowmelt. They appear to be much less dependent on human-made sources in winter. Gold Meadows Spring became dry in October of 2006 as in the previous year. Horses were grazing in Gold Meadows as of late October even though no permanent water was available in the area. As in past years, none of the plastic-lined sumps within or near the horse range were used by horses this year. 


\subsection{Deer Abundance on the NTS}

Mule deer (Odocoileus hemionus) abundance on the NTS is measured by driving two standardized (77-km [48-mi] total length) road courses (Figure 6-27) to count and identify mule deer. Counts are made by two observers with spotlights in a vehicle moving at a constant speed of about 10-15 kilometers/hour (6.2-9.3 miles/hour). When deer or predators are spotted (e.g. Figure 6-28), the vehicle is stopped and observers use binoculars to count and classify animals according to age (adult, spike, fawn, etc) and sex, if possible. A spotlighting session involves three consecutive nights of work; counts were made during a single session each year from 1989-1994. The sampling increased to two sessions a year during 1999 and 2000; and three sessions were completed in 2006. All sessions are conducted from August to October.

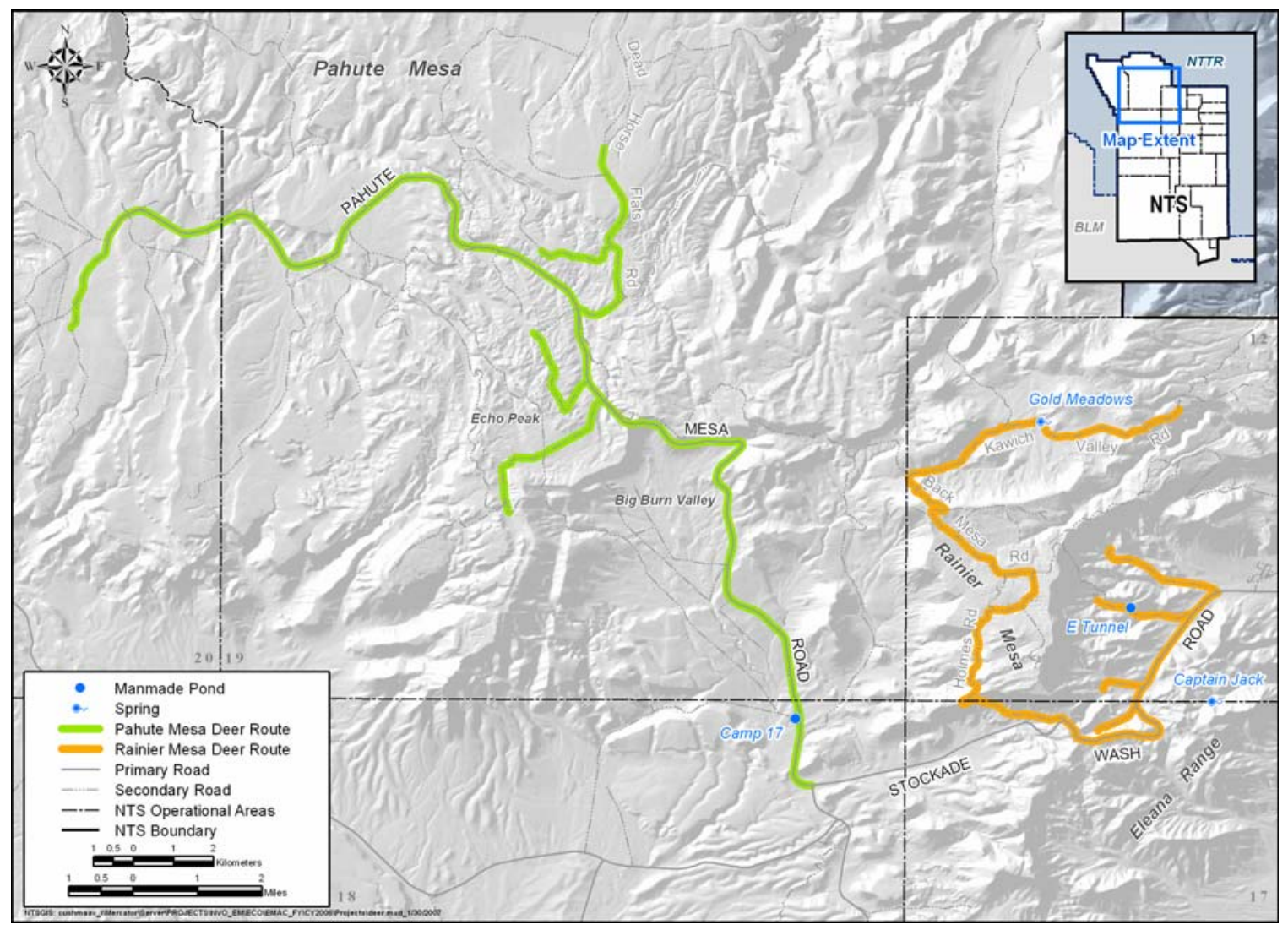

Figure 6-27. Roads driven on the NTS to count deer from 1989-2006. 


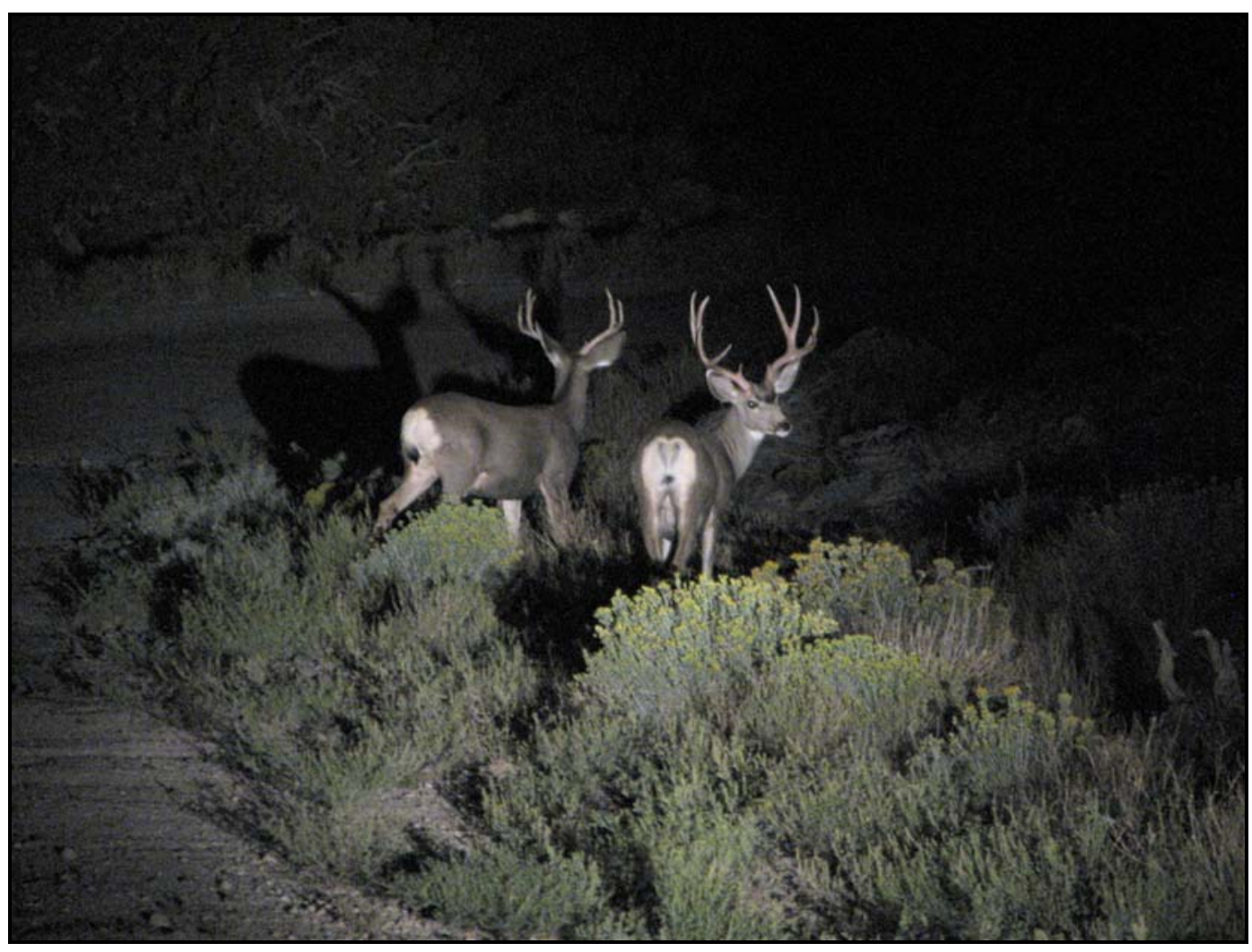

Figure 6-28. Image of two male mule deer spotlighted on the Rainer Mesa Route. (Photo by D. B. Hall, September 13, 2006)

Annual deer counts from 1989-1994 ranged from a high of 131 in 1992 to a low of 47 in 1994, showing a declining trend through a period of drought followed by a moderate recovery in numbers in 1992 and 1993 (Figure 6-29). Deer counts reached an all-time NTS low during 1999 and 2000 with a range of 27 to 42 deer per session. Deer counts have increased since 2000 to an all time high of 245 during the September 2006 session. Male to female sex ratios (224/222) averaged 1.009 for 2006. The increase in deer on NTS may be in part from immigration from herds of central Nevada that have been increasing in numbers in recent years.

From 1989 to 1999, deer abundance indices on the Pahute Mesa route normally were higher than the counts on the Rainier Mesa route (Table 6-8). This is consistent with Giles and Cooper's assessments (1985) that the Pahute Mesa herd was always much larger in numbers than the Rainier Mesa herd. However, from October 2000 to 2006, the number of deer sighted per distance on the Rainier Mesa route was higher than on the Pahute Mesa route (Table 6-8). Deer abundance on Pahute Mesa this year is slightly higher than levels from earlier years. The increased numbers of deer counted per distance around Rainer Mesa are quite convincing of increased summer-fall residency in this region. 


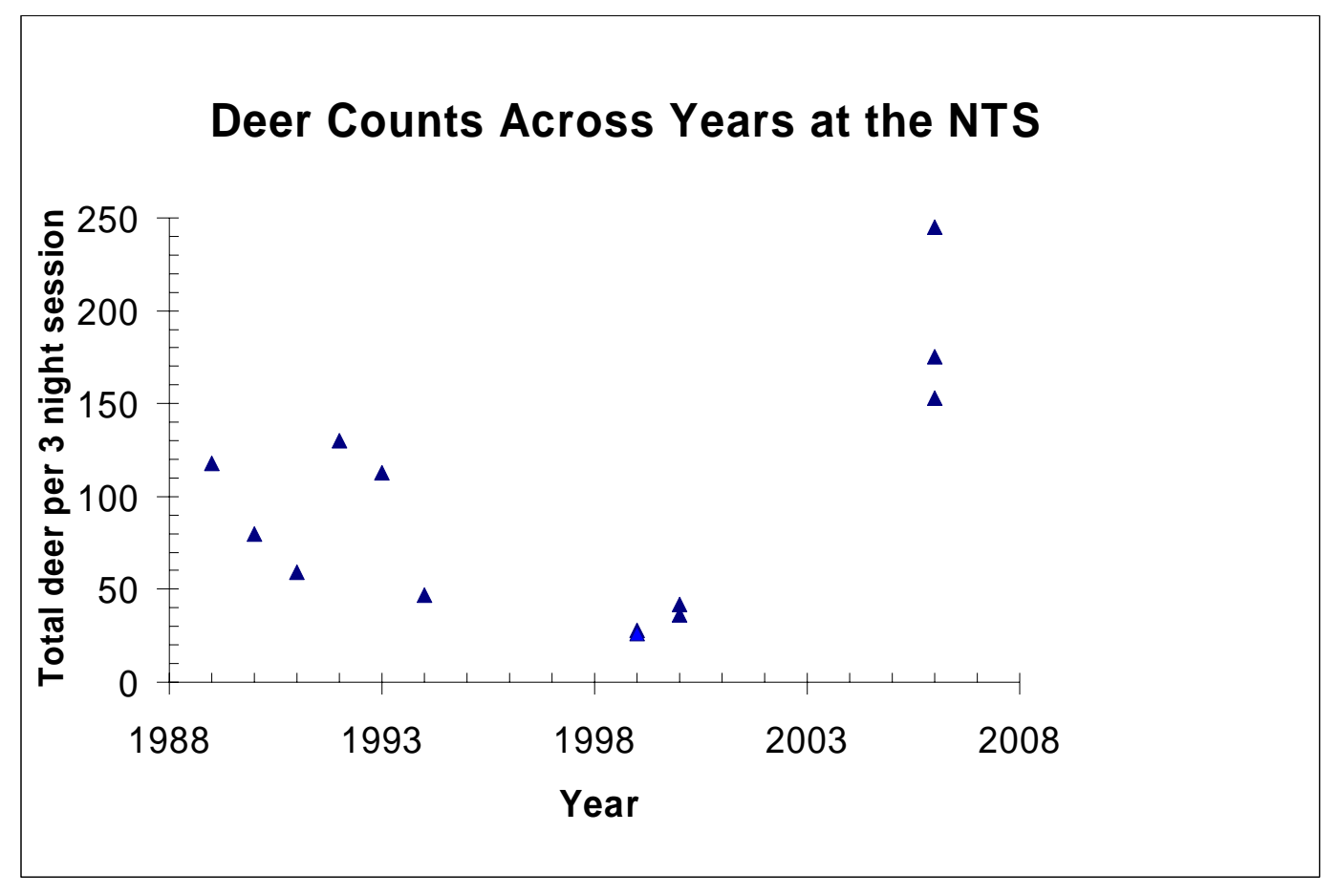

Figure 6-29. Trends of deer spotlighting counts on the NTS from 1989-2006. No data occurred for 1995-1998 and 2001-2005.

Table 6-8. Trends in deer counts per three-night session and an abundance index for two sampling regions on the NTS.

\begin{tabular}{|c|c|c|c|c|}
\hline \multirow[b]{2}{*}{ Date } & \multicolumn{2}{|c|}{ Pahute Mesa Route } & \multicolumn{2}{|c|}{ Rainier Mesa Route } \\
\hline & Total Deer & Mean Deer/10km & Total Deer & Mean Deer/10km \\
\hline Aug-1989 & 104 & 6.7 & 14 & 2.3 \\
\hline Sep-1990 & 66 & 4.4 & 14 & 1.8 \\
\hline Sep-1991 & 32 & 2.1 & 27 & 2.9 \\
\hline Sep-1992 & 98 & 6.4 & 33 & 3.7 \\
\hline Oct-1993 & 87 & 5.7 & 26 & 3.1 \\
\hline Oct-1994 & 37 & 2.6 & 10 & 1.2 \\
\hline Aug-1999 & 23 & 1.7 & 5 & 0.5 \\
\hline Oct-1999 & 16 & 1.3 & 11 & 1.2 \\
\hline Aug-2000 & 27 & 1.9 & 9 & 1.1 \\
\hline Oct-2000 & 17 & 1.2 & 25 & 3.0 \\
\hline Aug-2006 & 98 & 7.3 & 77 & 9.4 \\
\hline Sep-2006 & 131 & 9.7 & 114 & 13.9 \\
\hline Oct-2006 & 66 & 4.9 & 87 & 10.6 \\
\hline
\end{tabular}


Food quality may be poorer in the lower western slopes of Pahute Mesa (Areas 19-20) as opposed to the higher wetter Echo Peak area, which still boasts moderately high counts even in the absence of a permanent water source there. More permanent water sources around Rainier Mesa and potentially improved food quality as a result of re-sprouting or new growth of shrubs after the Egg Point Fire in 2002 may help explain higher summer and fall deer usage. Additional deer counts will be conducted in the future to see if this pattern continues to hold.

\subsection{Mountain Lion Camera Surveys}

Little data exist for mountain lion (Puma concolor) numbers and distribution in southern Nevada. Erin Boydston, a research scientist with USGS, received funding to investigate mountain lion distribution and abundance using remote, motion-activated cameras. NSTec biologists collaborated with Ms. Boydston to set up several cameras on the NTS to help determine how many mountain lions are found here and where they occur.

To date, 72 records from opportunistic sightings of mountain lions or their sign have been recorded on the NTS (EGIS faunal database). In 2006, 11 sightings of mountain lions or their sign were documented. Six of these were in forward areas away from human activity and five of them were near human activity (three in Area 6 [one near gas station, one near DAF, and one near Control Point Hill], two in Area 27 near Super Kukla Site). Knowing how many mountain lions occur and how they are distributed on the NTS will enable NSTec biologists to better assess the potential threat of mountain lions to NTS workers.

During 2006, remote, motion-activated cameras (TM700v and TM550 passive infrared trail monitors, Goodson \& Associates, Inc., Lenexa, Kansas; Stealth Cam STC-ADX, STC-AD3, and STC-AD2 digital system, Stealth Cam, LLC, Bedford, Texas; and Sony Digital CamTrakkerTM system, CamTrak South, Inc., Watkinsville, Georgia) were set up at 12 sites (Table 6-9). Sites were selected based on previous mountain lion sightings and areas known to be frequented by mule deer (e.g., deer trails, water sources), a primary prey species of the mountain lion. Thousands of photographs were taken yet only one mountain lion was photographed (Figure 6-30). This suggests that it is difficult to document mountain lion distribution and abundance using motion-activated cameras; however, cameras will continue to be used on the NTS until a better technique is identified.

A secondary objective of the camera surveys is to detect other species using these areas to better define species distributions on the NTS. Water sources are especially important to sample because many species, including mountain lions, rely on these water sources for survival. Results prove that a variety of wildlife (at least 29 species of mammals and birds) are using the different sites with the greatest activity at water sources, particularly during the dry summer and fall months. 
Table 6-9. Results of mountain lion camera surveys during 2006 (the number of photos are shown in parenthesis).

\begin{tabular}{|c|c|c|}
\hline Location & Dates sampled & Results \\
\hline Tub Spring & $1 / 4-12 / 31$ & $\begin{array}{l}\text { Mountain lion (1), chukar ( } 541) \text {, common raven (107), mule deer ( } 86) \text {, mourning } \\
\text { dove ( } 84 \text { ), coyote }(40) \text {, bobcat (5), songbirds (5), desert cottontail (2), American } \\
\text { kestrel (2), rufous-sided towhee (1), pinyon jay (1), raptor (1), white-tailed } \\
\text { antelope ground squirrel (1), bat (1) }\end{array}$ \\
\hline $\begin{array}{l}\text { Old Area } 12 \text { sewage } \\
\text { ponds }\end{array}$ & $1 / 4-6 / 15$ & Mule deer (91), coyote (28), black-tailed jackrabbit (16), northern harrier (1) \\
\hline E Tunnel Ponds & $1 / 4-4 / 18 ; 11 / 16-12 / 27$ & Mule deer (74), golden eagle (5) \\
\hline Whiterock Spring & $1 / 18-5 / 15 ; 11 / 20-12 / 31$ & $\begin{array}{l}\text { Mule deer (198), desert cottontail (35), black-tailed jackrabbit (9), Gambel's } \\
\text { quail (7), desert woodrat (4), common raven (3), chukar (1), Cooper's hawk (1) }\end{array}$ \\
\hline Well 3 Pond & $3 / 15-6 / 15$ & $\begin{array}{l}\text { Coyote (44), black-tailed jackrabbit (13), bobcat (9), common raven (8), desert } \\
\text { cottontail (2), great blue heron (2), mourning dove (2), great egret (1) }\end{array}$ \\
\hline Camp 17 Pond & $3 / 15-21 / 31$ & $\begin{array}{l}\text { Horse }(1,061) \text {, mule deer (193), common raven (135), songbird (4), coyote (1), } \\
\text { brown-headed cowbird (1), turkey vulture (1), raptor (1) }\end{array}$ \\
\hline Tippipah Spring & $3 / 15-12 / 31$ & $\begin{array}{l}\text { Mule deer (195), black-tailed jackrabbit (92), coyote (48), chukar (9), bobcat (3), } \\
\text { common raven (3), desert cottontail (1) }\end{array}$ \\
\hline Reitmann Seep & $4 / 5-6 / 6$ & Mourning dove (10), mule deer (4), coyote (3) \\
\hline KV-1, Gold Meadows & $6 / 15-11 / 20$ & Mule deer (35), horse (9), coyote (1) \\
\hline 12T-26, Rainier Mesa & $6 / 15-12 / 31$ & $\begin{array}{l}\text { Black-tailed jackrabbit (27), mule deer (21), gray fox (16), coyote (9), desert } \\
\text { cottontail (6), common raven (6), bobcat (2) }\end{array}$ \\
\hline Gold Meadows Spring & $6 / 15-8 / 30$ & $\begin{array}{l}\text { Mule deer (278), common raven (244), horse (202), bat (19), pronghorn } \\
\text { antelope (18), songbird (15), mourning dove ( } 9 \text {, western kingbird (3), turkey } \\
\text { vulture (3), brown-headed cowbird (2), bobcat (1), coyote (1), black-tailed } \\
\text { jackrabbit (1), chukar (1), lesser nighthawk (1), Cooper's hawk (1), raptor (1) }\end{array}$ \\
\hline $\begin{array}{l}\text { Captain Jack Spring, } \\
\text { South Trail }\end{array}$ & $7 / 20-11 / 16$ & $\begin{array}{l}\text { Coyote (3), desert cottontail (3), bobcat (1), black-tailed jackrabbit (1), greater } \\
\text { roadrunner (1) }\end{array}$ \\
\hline
\end{tabular}




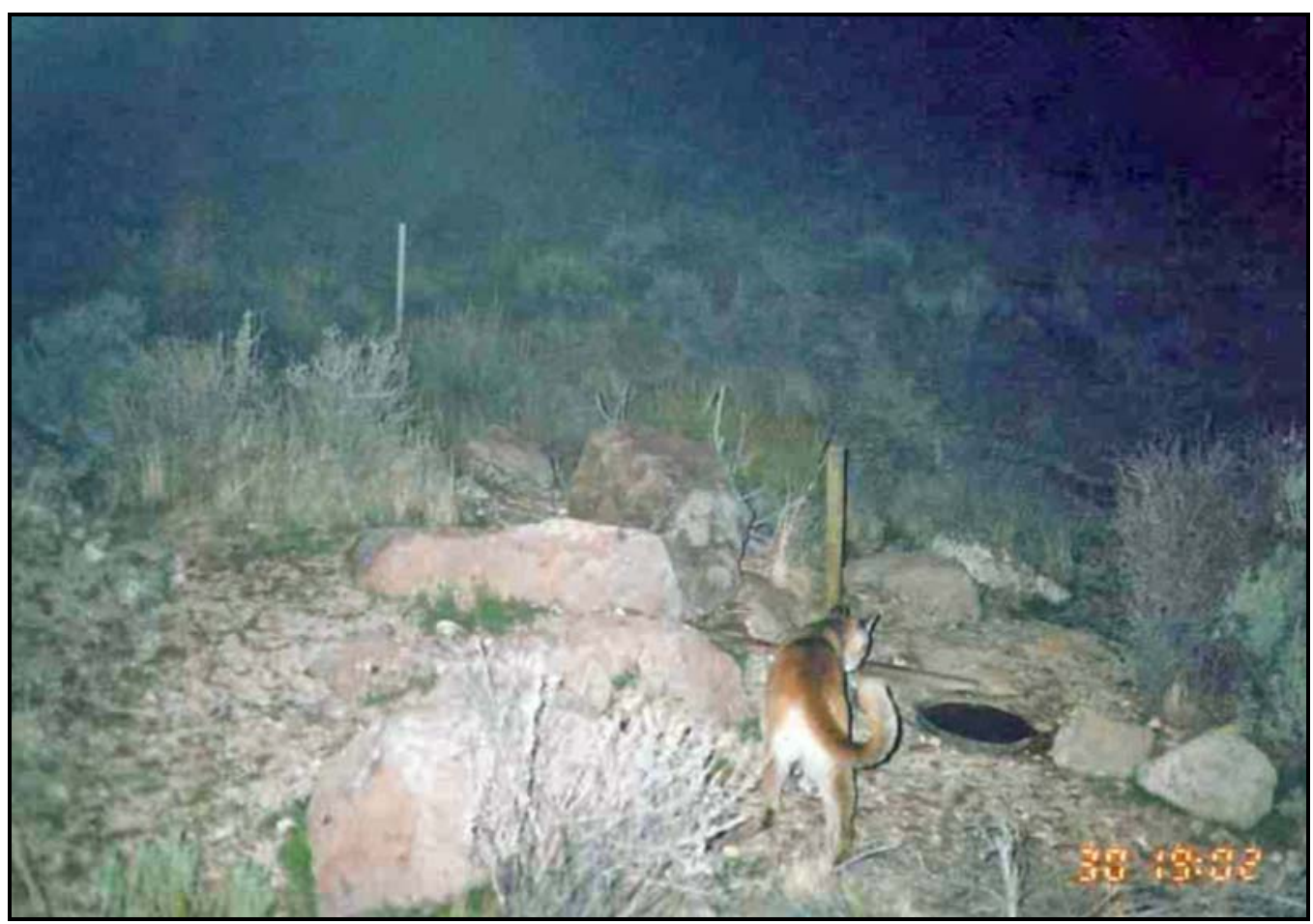

Figure 6-30. Mountain lion (Puma concolor) photographed at Tub Spring. (Photo taken by remote camera, March 30, 2006)

\subsection{Coordination with Biologists and Wildlife Agencies}

Dr. Courtney Conway from the University of Arizona is working on a Department of Defense Legacyfunded project evaluating migratory linkages of western burrowing owls in western North America. This involves trapping and banding burrowing owls and taking feather and blood samples. Feathers will be analyzed for specific stable isotopes to help determine migratory status and breeding and wintering locations. Dr. Conway contacted NSTec biologists to request their assistance in collecting samples on the NTS. Trapping results can be found in Section 6.2.

An NSTec biologist attended the $13^{\text {th }}$ Annual Meeting of The Wildlife Society in Anchorage, Alaska, and presented a poster entitled, "Radionuclides in bats using a contaminated pond on the Nevada Test Site, USA."

A collaborative effort using remote, motion-activated cameras to investigate mountain lion distribution and abundance on the NTS continued this year in conjunction with Erin Boydston, a USGS research scientist. For details see Section 6.8.

An NSTec biologist was elected as Co-leader of the Nevada Bat Working Group and attended a group meeting in December. He also served as a board member of the Western Bat Working Group. Affiliation with these groups is important to keep abreast of the latest techniques in bat monitoring and facilitates data exchange within the bat community. The Revised Nevada Bat Conservation Plan (Bradley et al., 2006) was finalized and signed by several federal and state agencies responsible for managing bats and their habitat in Nevada. An NSTec biologist was involved in writing this plan. 


\subsection{HABITAT MONITORING}

\subsection{West Nile Virus Surveillance}

West Nile Virus (WNV) is a potentially serious illness that is spread to humans and other animals through mosquito bites. It was first discovered in Uganda in 1937 and was not detected in North America until 1999. In southern Nevada, it was not detected until the spring of 2004. WNV surveillance continued in 2006 for the third consecutive year to determine if mosquitoes on the NTS carry WNV. WNV surveillance entails setting mosquito traps baited with dry ice overnight at sites where standing water provides a potential breeding ground for mosquitoes (Figure 7-1). As the dry ice sublimates, it produces carbon dioxide which serves as an attractant for mosquitoes. Eight sites were sampled during 14 surveys (Table 7-1). Mosquitoes were taken to Clark County Health District personnel for species identification and WNV testing. A total of 111 individuals representing 6 species were captured and analyzed (Table 7-1). All specimens tested for WNV were negative except for one Culiseta inornata from Well 3 Pond which was suspect. An individual mosquito from the same location last year was also suspect. According to the Nevada Department of Agriculture:

"A suspect sample is one that either tests positive for one of the two assays that is run or gives a reading above a certain cycle threshold. The threshold was set at 35 for CDC1 and 36 for CDC2 (loosely meaning that the signal was too weak to trust). This indicates that sample could be very weakly positive, have background inflorescence from the probe, or could have some cross contamination. One cannot tell which one it is, so that is where the suspect designation comes into play. CDC1 is a screening assay and CDC2 is the confirmation assay. If a sample tests positive for one and not the other, then that particular sample probably has a mutation of the WN1V viral RNA [ribonucleic acid] that is not picked up by the test that was developed by the CDC [Centers for Disease Control]." (Priest to Raman, 2006).

The reading for the specimen collected was 37 for CDC1 and 36 for CDC2. Therefore, it may be possible that WNV is present in at least one mosquito species on the NTS, but it is yet to be confirmed. This site will be sampled more intensively along with other sites next year to try to confirm if WNV is present on the NTS. Mosquito species identified will be entered into the EGIS faunal database to define mosquito distribution on the NTS. This year, three new species were detected.

Additionally, six injured raptors (three barn owls, two red-tailed hawk, and one prairie falcon were taken to the North Las Vegas Animal Hospital for WNV testing. All tested negative for WNV. 


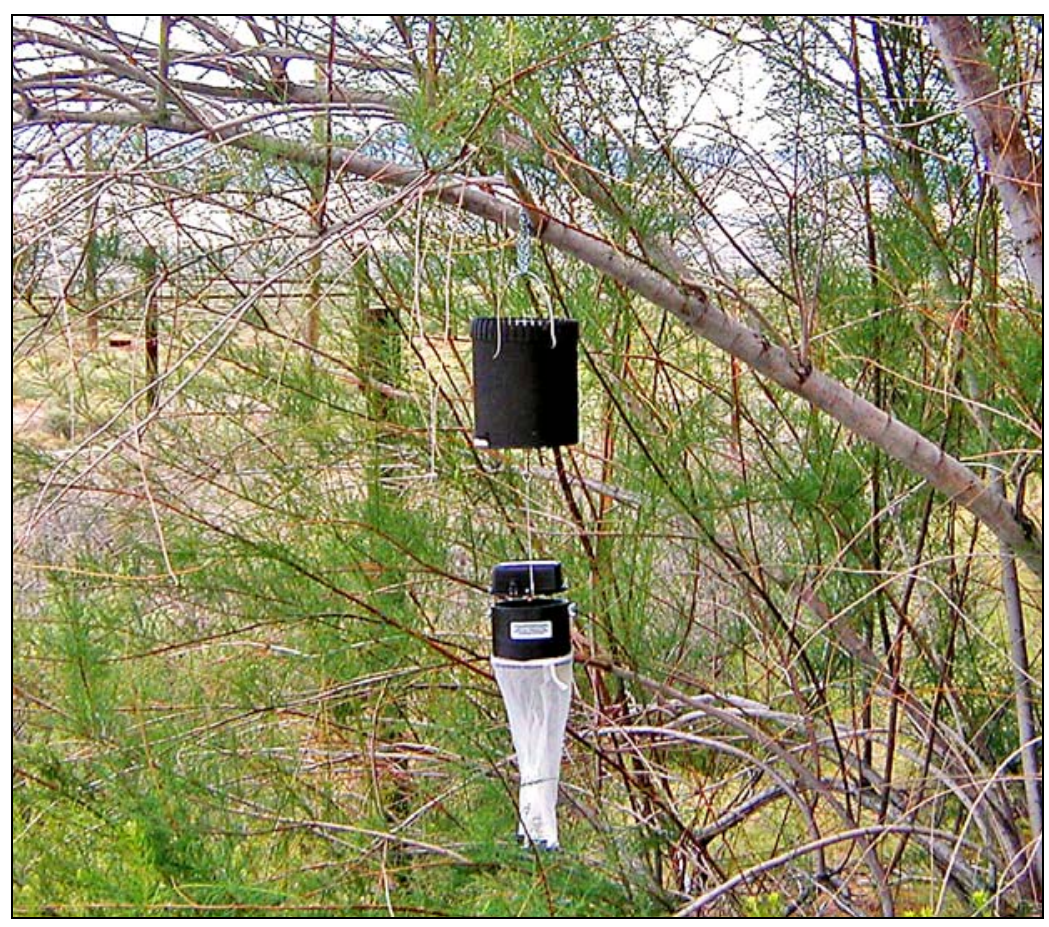

Figure 7-1. Mosquito trap set at Well 5B in Frenchman Flat. (Photo by D. B. Hall, May 2, 2005)

Table 7-1. Results of WNV surveillance on the NTS in 2006.

\begin{tabular}{|lccll|}
\hline \multicolumn{1}{|c}{ Location } & Date & $\begin{array}{c}\text { Number } \\
\text { Captured }\end{array}$ & \multicolumn{1}{c|}{ Species } & WNV \\
\hline Well 3 Pond & $5 / 30 / 2006$ & 0 & NA & NA \\
Well 5B & $5 / 30 / 2006$ & 2 & Ochlerotatus dorsalis & Negative \\
Well 5B & $5 / 30 / 2006$ & 1 & Culex erythrothorax & Negative \\
Mercury Sewage & $5 / 30 / 2006$ & 0 & & \\
Lagoons & $7 / 5 / 2006$ & 0 & NA & NA \\
Well 3 Pond & $7 / 5 / 2006$ & 5 & Culex tarsalis & Negative \\
Area 6 LANL Pond & $7 / 5 / 2006$ & 0 & NA & NA \\
Mercury SOC Park & $7 / 11 / 2006$ & 4 & Culex tarsalis & Negative \\
Whiterock Spring & $7 / 11 / 2006$ & 1 & Culiseta incidens & Negative \\
Whiterock Spring & $7 / 11 / 2006$ & 0 & NA & NA \\
Well 3 Pond & $8 / 28 / 2006$ & 0 & NA & NA \\
Mercury SOC Park & $8 / 28 / 2006$ & 22 & Culex tarsalis & Negative \\
Well 5C & $8 / 28 / 2006$ & 38 & Culex tarsalis & Negative \\
Well 3 Pond & $8 / 28 / 2006$ & 1 & Culiseta inornata & Suspect \\
Well 3 Pond & $9 / 11 / 2006$ & 0 & NA & NA \\
Mercury Sewage & $9 / 11 / 2006$ & 28 & Culex tarsalis & Negative \\
Lagoons & $9 / 11 / 2006$ & 1 & Culex erythrothorax & Negative \\
Well 5B & $9 / 11 / 2006$ & 1 & Culiseta inornata & Negative \\
Well 5B & $9 / 11 / 2006$ & 3 & Culex tarsalis & Negative \\
Well 5B & $9 / 11 / 2006$ & 3 & Culiseta inornata & Negative \\
Camp 17 Pond & $9 / 11 / 2006$ & 1 & Anopheles franciscanus & Negative \\
Camp 17 Pond & & & & \\
Camp 17 Pond & & & &
\end{tabular}




\subsection{Wetlands and Wildlife Water Sources}

Natural wetlands (e.g., vegetated seeps and springs) and human-made water sources (e.g., sumps and sewage lagoons) on the NTS provide unique habitats for vegetation and wildlife. In prior years, natural wetlands on the NTS were evaluated for their potential to qualify as "jurisdictional wetlands" under the Clean Water Act (CWA). The presence of three wetland field indicators (vegetation, hydrology, and soils) was the basis for determining whether individual wetlands might be considered jurisdictional wetlands (i.e., wetlands over which the U.S. Army Corps of Engineers [USACE] takes legal jurisdiction for the purposes of permitting, mitigation, and rehabilitation for site alterations).

Inherent in the concept of jurisdictional wetlands was the assumption that isolated wetlands were important for interstate commerce such as hunting, recreation, or for other related uses as defined by the CWA. In 2006, the Supreme Court issued rulings in a pair of related cases (Rapanos v. United States, and Carabell v. U.S. Army Corps of Engineers). Justices stated that the CWA does not extend jurisdiction to channels through which water flows intermittently or channels that provide drainage for rainfall. At issue were isolated wetlands that appear to include the types of wetlands found on the NTS. From initial national and local reaction to the rulings, it appears that NTS wetlands would no longer be considered "jurisdictional wetlands." Although a formal request was initiated by NSTec in 2005 through NNSA/NSO to the USACE to clarify whether NTS wetlands were considered "jurisdictional" by USACE, to date no response has been issued formally. While the recent Supreme Court ruling will most likely alter the potential of NTS wetlands from being considered jurisdictional, the rulings will not alter the basic underlying principle of protecting wetlands as unique and important habitats for wildlife. Characterization of these important mesic habitats and periodic monitoring of their hydrologic and biotic parameters were started in FY 1997 as components of EMAC and will continue in the future. This monitoring will help identify annual fluctuations and ranges in measured parameters to help determine if these fluctuations and ranges are natural or are related to NNSA/NSO activities.

\subsection{Constructed Wetlands Monitoring}

During 2006, constructed wetlands on Frenchman Flat were visited to check on water availability in January and were dry. Because of a dry spring, water did not collect long enough in constructed wetlands to warrant any further monitoring. However, plans exist for these wetlands to be sampled for shrimp in 2007 or at future dates when water will be present long enough for shrimp to complete their life cycle.

\subsection{Natural Wetlands Monitoring}

During 2006 no field characterization was done for new natural wetlands identified since 1987, nor was a technical supplement to the 1997 NTS wetland assessment (Hansen et al., 1997) finalized as anticipated in 2005. This was due to recent Supreme Court rulings and because field efforts were directed to assessing the impacts of wildland fires that occurred during the spring of 2006, a time optimally suited for monitoring wetlands. However, detailed descriptions of five previously described wetlands were formally prepared and archived in the EGIS database.

Monitoring of numerous wetlands continued this year to characterize seasonal baselines and trends in physical and biological parameters. Twelve wetlands were visited at least once during the year to record wildlife use, the presence/absence of land disturbance, water flow rates when applicable, and surface area of standing water (Figure 7-2). Sizes of wetlands monitored varied greatly from very small areas $\left(<1\right.$ square meters $\left.\left[\mathrm{m}^{2}\right]\right)$ to moderately sized springs $\left(180-200 \mathrm{~m}^{2}\right)$. Surface flow rates were low $(<2 \mathrm{~L} / \mathrm{min})$ at most wetlands where flow was measurable (Table $7-2)$. This year an emphasis was made to visit some of the more remote wetlands not visited in the last 5 years. 

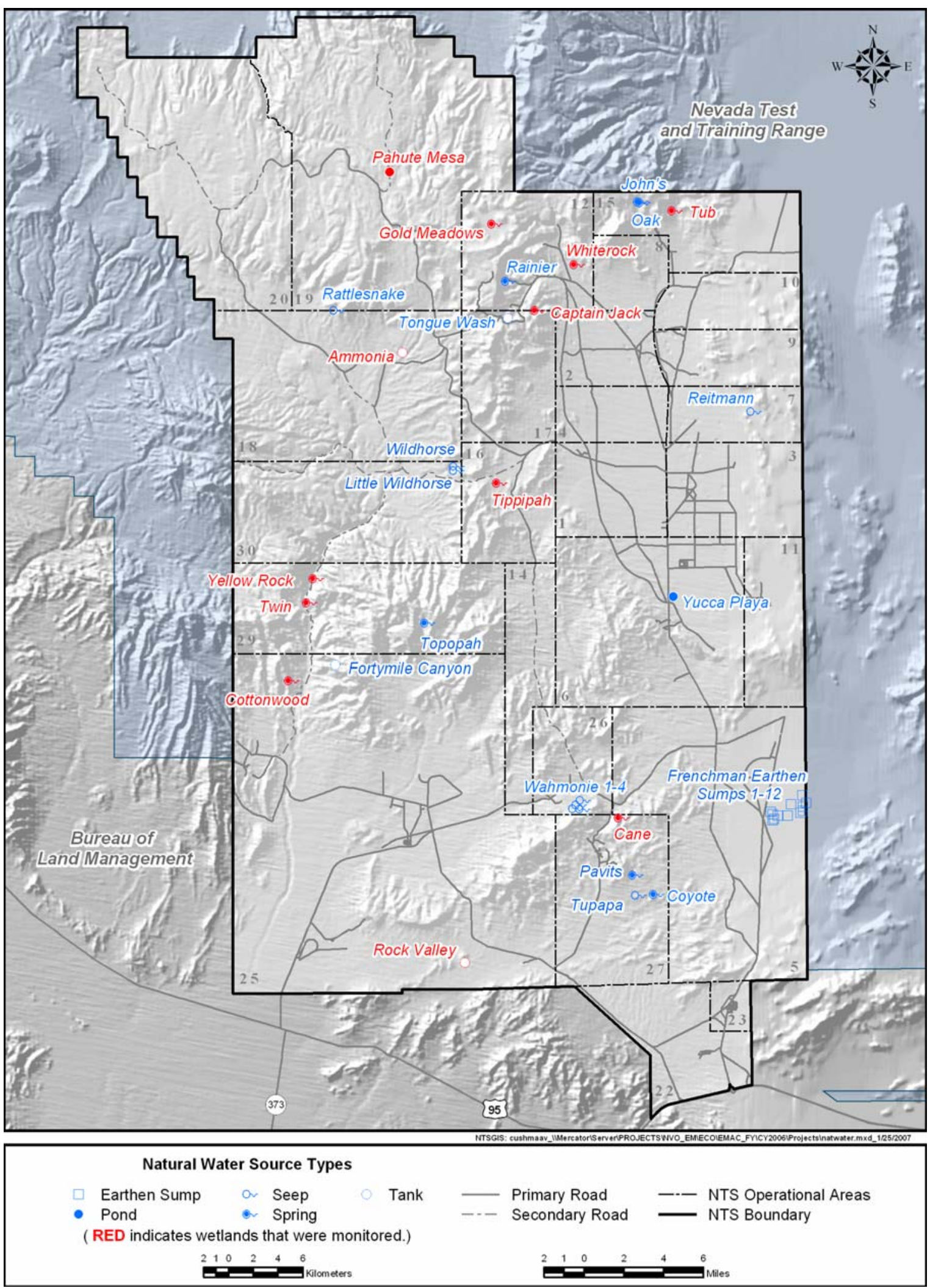

Figure 7-2. Natural water sources on the NTS, including those monitored in 2006. 
Table 7-2. Hydrology and disturbance data recorded at natural water sources on the NTS.

\begin{tabular}{|c|c|c|c|c|}
\hline Water Source & Date & $\begin{array}{c}\text { Surface } \\
\text { Area of } \\
\text { Water } \\
\left(\mathrm{m}^{2}\right)^{\mathrm{a}}\end{array}$ & $\begin{array}{l}\text { Surface } \\
\text { Flow Rate } \\
\text { (L/min) }^{\mathrm{b}}\end{array}$ & $\begin{array}{l}\text { Disturbance at } \\
\text { Spring }\end{array}$ \\
\hline Ammonia Tanks & $06 / 01 / 2006$ & 5 & 0 & None \\
\hline Ammonia Tanks & $06 / 07 / 2006$ & 5 & 0 & None \\
\hline Cane Spring & $12 / 05 / 2006$ & 10 & $N^{c}{ }^{c}$ & $\begin{array}{l}\text { Heavy cattail growth } \\
\text { in cave pool }\end{array}$ \\
\hline Captain Jack Spring & $11 / 19 / 2006$ & 30 & 0.9 & $\begin{array}{l}\text { Horse grazing and } \\
\text { trampling }\end{array}$ \\
\hline Cottonwood Spring & $05 / 31 / 2006$ & 1 & 0 & None \\
\hline Gold Meadows Spring & $07 / 12 / 2006$ & 200 & $\mathrm{NM}^{\mathrm{c}}$ & $\begin{array}{l}\text { Horse grazing and } \\
\text { trampling }\end{array}$ \\
\hline Gold Meadows Spring & $10 / 18 / 2006$ & 0 & 0.0 & Spring dry \\
\hline Pahute Pond & 08/28/2006 & 0 & 0 & None \\
\hline Rock Valley Tank & $12 / 13 / 2006$ & $<1$ & 0 & None \\
\hline Tub Spring & $12 / 12 / 2006$ & $<1$ & 0.03 & None \\
\hline Tippipah Spring & $07 / 18 / 2006$ & 180 & $N M^{c}$ & None \\
\hline Twin Spring & $04 / 15 / 2006$ & 1 & $N M^{c}$ & None \\
\hline Whiterock Spring & $07 / 11 / 2006$ & 4 & $N M^{c}$ & None \\
\hline Yellow Rock Springs & $04 / 25 / 2006$ & 1 & $N M^{c}$ & None \\
\hline
\end{tabular}

Wildlife use data recorded at water sources during day-time sampling are summarized in Table 7-3. Overall, few wildlife species and individuals were observed in 2006 compared to 2005 . Only 16 species and 236 individuals compared to 25 species of birds and more than 1,000 individuals were detected during 2005. Only small numbers of chukar (Alectoris chukar), Gambel's quail (Callipepla gambelii), and mourning doves (Zenaida macroura)were observed at springs throughout the NTS (Table 7-3). Some improvements were conducted at springs this year to benefit wildlife. A small guzzler at Tub Spring was installed to hold more water (an improvement over a wet patch of soil). In addition, a new guzzler was constructed at Whiterock Springs to aid in photography of wildlife. We used new camera techniques to photograph animals at night and to identify rarely observed species such as mountain lion, bobcat, grey fox, etc. (see Section 6.8).

Cane Spring was monitored specifically to check on the presence/status of a sensitive species of hydrobiid snail, called the southeast Nevada springsnail (Pyrgulopsis turbatrix), that lives there. The snail was present and alive during December of 2006. The status is generally checked every 5 years. Future work will attempt to make a relative density/population estimate in 2007. 
Table 7-3. Number of wildlife species observed or inferred at NTS natural water sources during 2006.

\begin{tabular}{|c|c|c|c|c|c|c|c|c|c|c|c|c|c|}
\hline $\begin{array}{c}\text { Wild life Species Observed at NTS } \\
\text { Natural Water Sources }\end{array}$ & 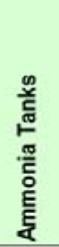 & 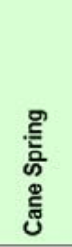 & 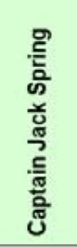 & 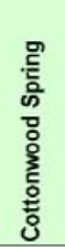 & 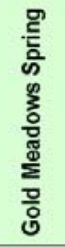 & 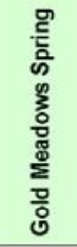 & 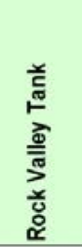 & 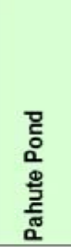 & 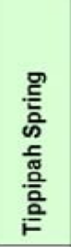 & 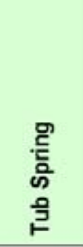 & 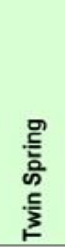 & 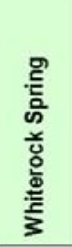 & 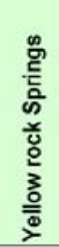 \\
\hline Date Observed (month/day) of 2006: & $6 / 1$ & $12 / 5$ & $10 / 19$ & $5 / 31$ & $7 / 12$ & $10 / 15$ & $12 / 13$ & $8 / 28$ & $7 / 18$ & $12 / 12$ & $4 / 15$ & $7 / 11$ & $4 / 25$ \\
\hline \multicolumn{14}{|l|}{ Mammals } \\
\hline Coyote (Canus latrans) & $\mathrm{P}$ & $\mathrm{P}$ & $\mathrm{P}$ & & $\mathrm{P}$ & $\mathrm{P}$ & $\mathrm{P}$ & $\mathrm{P}$ & $\mathrm{P}$ & $\mathrm{P}$ & $\mathrm{P}$ & $\mathrm{P}$ & $\mathrm{P}$ \\
\hline Cottontail rabbit (Sylvilagus audubonii) & & 1 & & 1 & & & & & 1 & & & 2 & \\
\hline Bobcat (Lynx rufus) & $\mathrm{P}$ & & & & & & & & & & & & \\
\hline Feral horse (Equus caballus) & & & $\mathrm{P}$ & & $\mathrm{P}$ & $\mathrm{P}$ & & & & & & & \\
\hline Mountain lion (Puma concolor) & & & & & & & & & & $1 a$ & & & \\
\hline Mule deer (Odocoileus hemionus) & 1 & $\mathrm{P}$ & $\mathrm{P}$ & $\mathrm{P}$ & $\mathrm{P}$ & $\mathrm{P}$ & & $\mathrm{P}$ & $\mathrm{P}$ & $\mathrm{P}$ & $\mathrm{P}$ & $\mathrm{P}$ & \\
\hline Pronghorn Antelope (Antilocapra americana ) & & & & & 8 & & & & & & $\mathrm{P}$ & & \\
\hline \multicolumn{14}{|l|}{\begin{tabular}{|c|} 
Birds \\
\end{tabular}} \\
\hline Black-throated sparrow (Amphispiza bilineata) & 3 & & & & & & & & & & 5 & & \\
\hline Bushtit (Psaltriparus minimus) & & & $>15$ & & & & & & & & & & \\
\hline Canyon wren (Catherpes mexicanus) & & & & & & & & & & & 1 & & \\
\hline Chukar (Alectoris chukar) & $>10$ & & $>10$ & $>15$ & & & & & $>10$ & $>15$ & $>10$ & & $>10$ \\
\hline Common raven (Corvus corax) & 2 & & 1 & & & & 1 & & & & & 2 & \\
\hline Cooper's hawk (Accipiter cooperi) & & & 1 & & & & & & & & & 1 & \\
\hline Gambel's quail (Callipepla gambelii) & & $>15$ & & & $>10$ & & & & $>10$ & $>15$ & $>10$ & $>10$ & $>10$ \\
\hline Golden eagle (Aquila chrysaetos) & & & & & & & & & 1 & & & & \\
\hline Mouming dove (Zenaida macroura) & $>3$ & & & & $>3$ & & & & $>1$ & & & $>10$ & \\
\hline Oregon Juncos (Junco Hyemalis) & & & $>5$ & & & & & & & & & & \\
\hline Red-tailed hawk (Buteo jamaicensis ) & & & 1 & & & & & & & & & & \\
\hline Rock Wren ( Salpinctes obsoletus) & & & & $>1$ & & & & & & & & & \\
\hline Sage Sparrows (Amphispiza belli) & & $>10$ & & & & & & & & & & & \\
\hline Say's phoebe (Saya sayornis ) & & & & & & & & & 2 & & & & 2 \\
\hline White-crowned sparrow (Zonotrichia leucophyrs) & & & $>5$ & & & & & & & & & & \\
\hline Long-eared owl (Asio otus) & & & & & & & & & & & & 1 & \\
\hline Numbers of bird species detected: & 4 & 2 & 7 & 2 & 2 & 0 & 1 & 0 & 5 & 2 & 4 & 5 & 3 \\
\hline
\end{tabular}

$\mathrm{P}=$ Species presence inferred from sign

"aphotographed on 3/30/2006 
The excessive growth of cattails and restriction of light into the cave pool was considered as a possible natural impact if reduction in algae might influence numbers of snails in the pool. The snail was found to be present only in the outflow $8 \mathrm{~m}(26 \mathrm{ft})$ below the cave pool and was absent from the cave pool where it normally occurs. Possible mitigation is to cut back the cattails so sunlight can illuminate the cave pool to increase the area used by the snail.

\subsection{Constructed Water Source Monitoring}

NSTec biologists conducted quarterly monitoring of constructed water sources. These sources, located throughout the NTS (Figure 7-3) include 38 plastic-lined sumps. Several ponds or sumps are located next to each other at the same project site. Many animals rely on these human-made structures as sources of free water. However, wildlife and migratory birds may drown in steep-sided or plastic-lined sumps as a result of entrapment, or ingest contaminants in sumps with drilling-fluids or evaporative ponds. Ponds are monitored to assess their use by wildlife and to develop and implement mitigation measures to prevent them from causing significant harm to wildlife.

Constructed water sources (Figure 7-3) were visited during four quarterly sampling periods: March, June, September, and December 2006. At each site, a NSTec biologist recorded the presence or absence of standing water and the presence of animals or their sign around the water source. The presence of sediment ramps or plastic ladders, which allow animals to escape if they fall in, have also been installed at many plastic-lined sumps, and the presence, absence, and condition of these structures were also noted. All dead animals (or any remains of an animal) in or adjacent to a human-made water source are recorded.

During 2006, use of plastic-lined sumps was generally low for birds due to dry conditions with reduced surface area as the summer progresses. Use was limited to few passerine birds, shorebirds and ducks [e.g., common ravens (Corvus corax), turkey vultures,(Cathartes avra), horned larks (Eremophila alpestris), house finches (Carpodacus mexicanus), eared grebes (Podiceps nigricollis), and teal (Anas spp.) ]. Sumps are commonly used by coyotes (Canis latrans) and sometimes mountain lions searching for deer. Two dead deer were detected at plastic-lined sumps during 2006, both at Environmental Restoration (ER-) 20-6, Sumps \#5 and \#6 (Table 7-4). Two sediment ramps were constructed this year in Sumps \#5 and \#6 at ER 20-6 to mitigate future deer entrapment. These sumps will be monitored closely in 2007 to evaluate their effectiveness. It is recommended that sediment ramps be constructed in every deep sump on the northern NTS where deer abundance is high. There are presently 8 deep sumps in Area 20 that need sediment ramps; they are located at ER-20-2, ER-20-5, ER-20-6, and UE20N-PS\#1. Sediment ramps, where installed, have been very effective in allowing animals to exit sumps without becoming entrapped.

Table 7-4. Results of monitoring plastic-lined sumps for wildlife mortality at the NTS for 2006.

\begin{tabular}{|c|c|c|c|c|c|}
\hline Quarter $^{\mathrm{a}}$ & $\begin{array}{c}\text { Number of } \\
\text { ponds } \\
\text { monitored }\end{array}$ & $\begin{array}{c}\text { Number of } \\
\text { ponds with } \\
\text { water }\end{array}$ & $\begin{array}{l}\text { Surface } \\
\text { area } \mathbf{m}^{2}\end{array}$ & $\begin{array}{c}\text { Number of } \\
\text { sediment } \\
\text { ramps }\end{array}$ & $\begin{array}{c}\text { Number of dead } \\
\text { animals } \\
\text { detected }\end{array}$ \\
\hline Jan-Mar & 38 & 38 & 7500 & 17 & 1 mule deer \\
\hline April-June & 38 & 20 & 3200 & 17 & none \\
\hline July-Sept & 38 & 11 & 1100 & 17 & none \\
\hline Oct-Dec ${ }^{b}$ & 25 & 18 & 3700 & 19 & 1 mule deer \\
\hline
\end{tabular}

\footnotetext{
${ }^{a}$ Monitoring conducted during last month of each quarter
}

${ }^{\mathrm{b}}$ Monitoring effort reduced due to snow covering ponds 


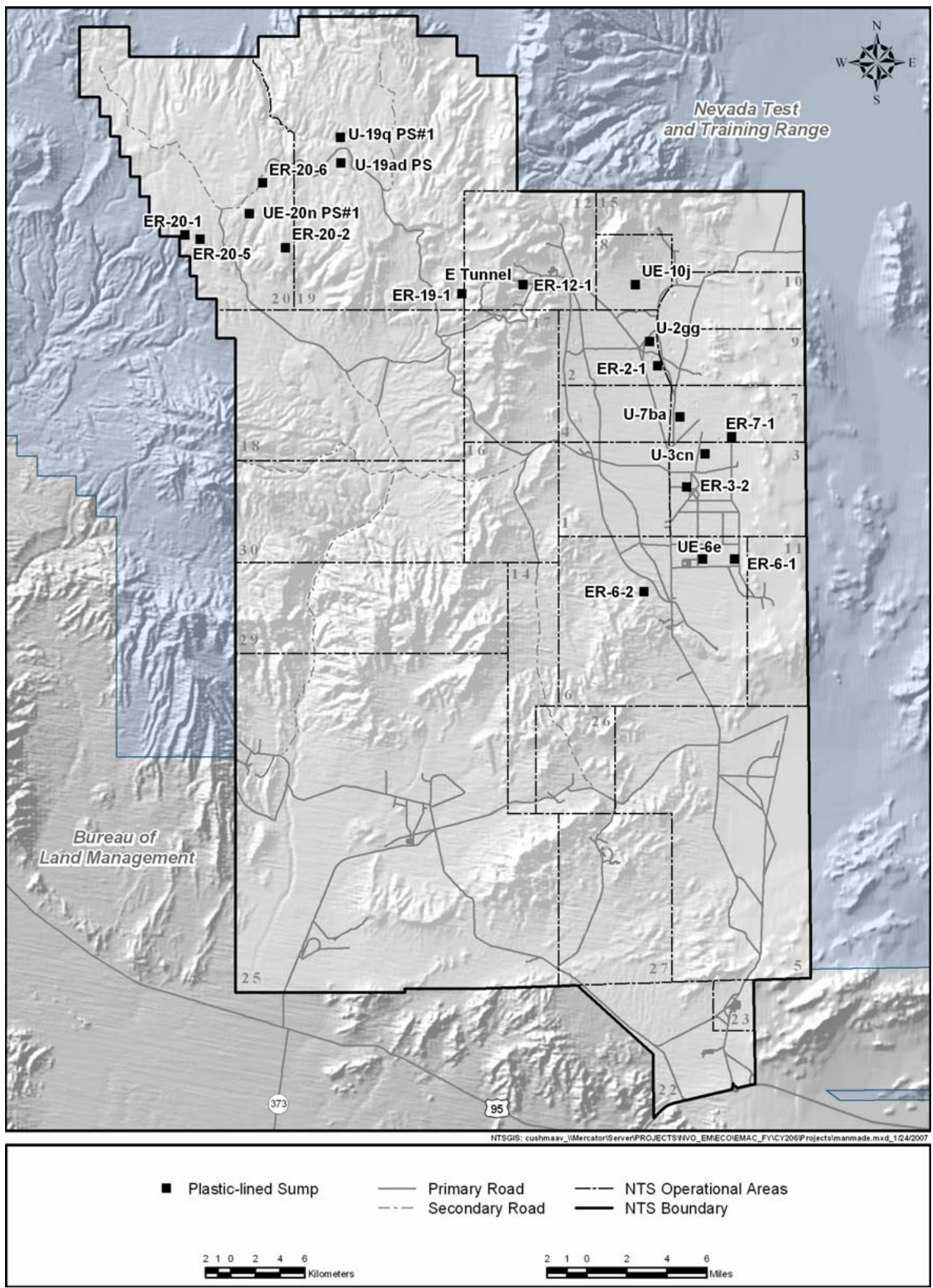

Figure 7-3. Constructed water sources monitored for wildlife use and mortality on the NTS during 2006. 


\subsection{HABITAT RESTORATION MONITORING}

The focus of the habitat restoration program on the NTS has changed over the years. In the 1970s and 1980s, habitat restoration efforts were on the research level and numerous trial plots were set up at various locations on the NTS. The primary objectives of these research plots were to reduce soil erosion, restore wildlife habitat, reduce wildland fire potential, and test revegetation techniques that could be employed on land disturbance in arid regions such as are found on the NTS. Revegetation procedures for the arid desert regions of the southwest vary with site and objectives although general procedures apply to almost all sites (Ostler et al., 2002). At these research sites. different seeding rates and mixes were evaluated. Seeding successes were compared to other studies that tested the survival of native shrubs using transplants. A range of different native plant species was evaluated. Many, if not most, of the research sites were in the lower, more arid regions of the NTS, primarily around Yucca and Frenchman flats (Romney et al., 1989; Hunter et al., 1980; Hunter et al., 1987; Wallace and Romney, 1980, Wallace et al., 1980).

In late 1980s and early 1990s, several imminent projects were going to require revegetation at an operational level and research began specific to those project areas. One such proposed program was the remediation of plutonium contaminated soils on the NTS and the TTR. Research focused on the specific sites to be remediated (Wallace and Romney, 1977; Winkel et al., 1994; Winkel, 1995). In some instances, the research occurred at the site but for the most part it was conducted in similar areas on the NTS, such as in Area 11, and 19. At Area 11, the effects of herbivory on transplants were evaluated as well as the importance of the source of plant materials (Winkel, 1993). At Area 19 in the Great Basin Desert region of the NTS, research focused on water harvesting/conservation techniques and plant species that were suitable for Great Basin Desert regions of the NTS. Restoration techniques, such as desert strips, pitting, land imprinting, and straw mulching were evaluated. Simultaneously with these efforts was work at Yucca Mountain where research refined direct seeding techniques and transplanting methodologies as well as the response of different native plant species to the different reclamation techniques being tested (Civilian Radioactive Waste Management System, 1999).

It was in the late 1990s when reclamation moved to an operational level. The Double Tracks remediation site, which was a little over 3 ha ( 9 ac), was seeded in the fall of 1996 using a mix of native shrubs, grasses and forbs. A portable irrigation system was installed to augment natural precipitation during the first growing season (Hall and Anderson, 1999). The following year four CAUs on the TTR were revegetated and a couple of years later remediation efforts were completed at the Central Nevada Test Area (CNTA) and U-3ax/bl CAU on the NTS (Anderson and Ostler, 2002). At four of the sites, the construction of a soil cover cap over waste materials, which was to be revegetated, was part of the closure design. Vegetation procedures varied somewhat among the different sites. At CNTA, a combination of seeding and transplanting was used. At all of the TTR sites only seeding was used. The U-3ax/bl site on the NTS was seeded and, like the Double Tracks site, was irrigated during the first growing season (BN, 2006). All sites were fenced to exclude large grazing animals, rabbits, or both.

Active restoration of sites burned by wildland fires has not been a common practice on the NTS, until a fire burned approximately 121 ha (330 ac) around facilities in Area 12. The fire, termed the Egg Point Fire, removed the vegetation from steep, rocky slopes, which created a risk of increased erosion during precipitation events. The area was revegetated in the fall of 2002 using seeding and transplanting methods. As an immediate protection to the exposed soils, a soil-stabilizing solution was applied to high-risk areas the following winter and spring. At several more recent wildland fire sites some seeding has occurred at the research level to evaluate timing of seeding as well as species performance. 
The habitat restoration monitoring program on the NTS continually looks at refining the revegetation procedures for the NTS. Research sites, project sites, cover caps. and wildland fires that have been revegetated are monitored periodically with the objective of evaluating long-term effects of certain procedures or long-term survival of plants, preserving these sites for future research, and refining current revegetation procedures. The results of the monitoring program on the NTS in 2006 are reported in the following sections.

\subsection{Monitoring Procedures}

Habitat restoration monitoring procedures vary from site to site but for the most part follow the same pattern. Sampling usually occurs during the period of peak production, late spring and early summer for most sites on the NTS and surrounding areas. Several linear transects are located on each site to provide a representative sampling of the site. Plant cover is measured beginning the $5^{\text {th }}$ year after revegetation occurred or as may be required by regulation. An ocular point projection device is used to estimate cover. The device is placed at predetermined intervals along each transect. At each placement of the device, ocular points (usually two or four) are projected downward and the type of cover, i.e., rock, bare ground, litter, mulch, or plant species, intercepted by the points is recorded. Typically, a minimum of 100 points are taken along each transect. Data for both cover and density are summarized for each transect and each site.

Plant density is measured the first 2-3 years or as dictated by any regulations or regulatory agency requirements. Density is measured using a series of quadrats usually $1 \times 1 \mathrm{~m}(3.3 \times 3.3 \mathrm{ft})$ in size. Each quadrat is placed at given intervals along the transect. At each quadrat location, plants that fall within the quadrat's boundaries are counted and recorded. Density is summarized for each species and for each lifeform (shrub, grass and forb).

In most cases reference sites are also sampled. Reference sites are representative of the type of vegetation that occurred prior to the disturbance and restoration activities. The amount of cover, the number of plants, and the kind of plants on the reference sites serve as standards for the restoration site and provide a means of determining reclamation success.

\subsection{Habitat Restoration Monitoring in 2006}

One of the objectives of the habitat restoration monitoring is to evaluate the long-term outcome of both natural vegetation succession and active revegetation at disturbed sites. Restoration sites are periodically monitored and the information obtained is used to develop site-specific habitat restoration plans for future restoration efforts, and to identify factors critical for successful revegetation for the different habitat types found on the NTS. Several project sites that involved revegetation were monitored this year. They included four CAUs on the TTR, a pipeline project in Area 6 on the NTS, and four vegetated cover caps, three on the TTR and one on the NTS. Two recent wildland fire sites on the NTS that were reseeded were also monitored in 2006 .

\subsubsection{Research Sites}

The habitat restoration research began in the 1970s on the NTS and continued into the 1990s. Most recent efforts have been more operational- and less research-oriented. Almost 30 different trials with native shrubs and grasses were initiated in the 1970s and 1980s. Many of these research sites have recently been located and a determination made as to their potential value based on the integrity of site, accessibility, and if sufficient information is available about the design and objective of the research. About half of the research sites were found to still exist and were determined to provide potentially useful information. These sites are monitored as part of the habitat restoration monitoring program on the NTS. 
In the 1990s, two sites were established to evaluate different techniques to enhance either transplant survival or increase seeding success. One site, located in Area 11 on the NTS, was designed to test the effects of herbivory and the sources of plant materials on plant survival. Next year, 2007, will mark 15 years since this study began and shrubs will be monitored for survival and vigor. The other study site is in Area 19 and was established in 1997 also. The effects of topsoil depth, water harvesting, seeding rates, and other reclamation techniques were evaluated. No research sites were monitored in 2006.

\subsubsection{Projects}

The Double Tracks remediation site on the TTR was scheduled to be monitored in 2006, ten years after revegetation, but access was restricted because of a site reevaluation. This site was the first of four storagetransportation nuclear test sites to be remediated and revegetated on the TTR (Hall and Anderson, 1999). Monitoring will be scheduled as soon as access restrictions are lifted.

Remediation of four corrective action units located on the TTR was completed in 1997 and those sites have been monitored periodically since then. In 2006, CAUs 400-Five Points Landfill, Bomblet Pit, 426-Cactus Springs Waste Trenches, and 404-Rollercoaster Sewage Lagoons were monitored. In addition, a water pipeline right-of-way in Area 6 of the NTS was reseeded in the fall/winter of 2005 and was monitored in 2006. The results of monitoring efforts for these projects are presented in the following sections.

\subsubsection{CAU 400-Five Points Landfill}

The Five Points Landfill was remediated and revegetated in the fall of 1997. The site is located upslope from Cactus Flats on the TTR. The major obstacle with revegetation at this site was that about two-thirds of the site is a depression, where water accumulates during periods of heavy precipitation. A heavy thunderstorm in the summer of 2004 caused a small pond that persisted for several weeks and resulted in the die-off of all of the vegetation in the lower-lying areas. The bottom areas at the site were reseeded that fall. Monitoring this year included those portions of the site that were revegetated in 1997 as well as the area reseeded in 2004.

Plant cover this year was only a percent lower than it was last year. The decline is attributable to a decrease in shrub and forb cover, the most significant being the 33-percent decrease in the amount of forb cover. The amount of cover from grasses, on the other hand, showed a 150-percent improvement, increasing from 1.3 percent in 2005 to 3.3 percent in 2006 (Table 8-1). Forb cover fluctuates from year to year depending on the amount and timing of annual precipitation.

Perennial plant cover, which comprises both shrub and grass cover, is a good indicator of the vigor and stability of the plant community. Shrubs and grasses are the plants that persist from year to year under the stress of low precipitation and high temperatures. The amount of perennial plant cover on the restoration site (11.8 percent) is slightly lower than that found on the undisturbed reference site (14.2 percent) (Table 8-1). For the last 4 years, the amount of shrub cover has been between 8.1 percent and 9.2 percent, which approximates the cover on the reference site. Grass cover has typically been lower the last few years. Apparently, drought conditions experienced in some of the past 6 years, have had a greater impact on the grasses than on the shrubs. Grass cover the first few years after revegetation ranged from 10 percent to 
Table 8-1. Plant cover on CAU 400-Five Points Landfill.

\begin{tabular}{lccccccc}
\hline & \multicolumn{8}{c}{ Percent Plant Cover } \\
& $\mathbf{2 0 0 0}$ & $\mathbf{2 0 0 2}$ & $\mathbf{2 0 0 3}$ & $\mathbf{2 0 0 4}$ & $\mathbf{2 0 0 5}$ & $\mathbf{2 0 0 6}$ & Reference \\
\hline Shrub & 2.5 & 8.3 & 9.2 & 8.1 & 9.0 & 8.5 & 8.3 \\
Grass & 10.0 & 22.5 & 10.0 & 3.7 & 1.3 & 3.3 & 5.8 \\
Forbs/Annuals & $\underline{3.3}$ & $\underline{1.7}$ & $\underline{0.0}$ & $\underline{2.2}$ & $\underline{9.0}$ & $\underline{6.0}$ & $\underline{0.0}$ \\
Total Plant Cover & 15.8 & 32.5 & 19.2 & 14.0 & 19.2 & 17.8 & 14.2 \\
& & & & & & & \\
Bare Ground & 17.5 & 17.5 & 23.3 & 26.5 & 11.5 & 20.5 & 22.5 \\
Litter & 66.7 & 50.0 & 57.5 & 59.6 & 69.2 & 61.8 & 63.3 \\
\hline
\end{tabular}

22 percent, but during the last 3 years when annual precipitation has been below average, grass cover dropped to a low of 1.3 percent last year and around 3.5 percent the other 2 years, and just about half of the amount of grass cover on the reference area.

Atriplex canescens (fourwing saltbush) has been the most dominant shrub at the site since seeding occurred (Table 8-2). In fact from 2003 to 2005, it was the only shrub found on the site. This year the density of A. canescens was the lowest it has ever been, dropping to just 0.5 plants $/ \mathrm{m}^{2}\left(0.05\right.$ plants $/$ square feet $\left.\left[\mathrm{ft}^{2}\right]\right)$ down from 1.4 plants $/ \mathrm{m}^{2}\left(0.13\right.$ plants $\left./ \mathrm{ft}^{2}\right)$ last year, the highest it had ever been. For the first time Krascheniinikovia lanata (winterfat) was found on the site. The overall decrease in the density of shrubs was accompanied by an increase in the density of grasses. The increase was mainly on a newly seeded area, where numerous young seedlings of both Elymus elymoides (squirreltail) and Achnatherum hymenoides (Indian ricegrass) were found. Even with the doubling of the number of grasses from 2005 to 2006, overall grass density is still lower than it was from 2002 to 2004. The density of annual forbs fluctuates from year to year depending on the amount of winter and spring precipitation. So far there has been no species of noxious plants to occupy the site in densities to warrant concern.

Shrub and grass cover at the Five Points Landfill site has been about the same for the last 3 years, after a high of 30.8 percent in 2002. The 11.8-percent perennial plant cover recorded in 2006 on the restoration site is about 84 percent of the perennial plant cover on the reference area. When considering shrub cover and grass cover separately, the amount of shrub cover on the restoration site actually exceeds the amount of shrub cover on the reference area. The amount of grass cover on the restoration site is much lower, however, only 3.3 percent compared to 5.8 percent on the reference area. 
Table 8-2. Plant density on CAU 400-Five Points Landfill.

\begin{tabular}{|c|c|c|c|c|c|c|c|}
\hline \multirow[b]{2}{*}{ Species } & \multicolumn{7}{|c|}{ Plants $/ \mathrm{m}^{2}$ with plants $/ \mathrm{ft}^{2}$ in parentheses } \\
\hline & 2000 & 2002 & 2003 & 2004 & 2005 & 2006 & Reference \\
\hline \multicolumn{8}{|l|}{ Shrubs } \\
\hline $\begin{array}{l}\text { Atriplex canescens } \\
\text { (fourwing saltbush) }\end{array}$ & $\begin{array}{c}0.7 \\
(0.07)\end{array}$ & $\begin{array}{c}1.0 \\
(0.09)\end{array}$ & $\begin{array}{c}1.4 \\
(0.13)\end{array}$ & $\begin{array}{c}1.1 \\
(0.10)\end{array}$ & $\begin{array}{c}1.4 \\
(0.13)\end{array}$ & $\begin{array}{c}0.5 \\
(0.05)\end{array}$ & $\begin{array}{c}0.1 \\
(0.01)\end{array}$ \\
\hline $\begin{array}{l}\text { Chrysothamnus greenei } \\
\text { (Greene's rabbitbrush) }\end{array}$ & $\begin{array}{c}0.0 \\
(0.00)\end{array}$ & $\begin{array}{c}0.0 \\
(0.00)\end{array}$ & $\begin{array}{c}0.0 \\
(0.00)\end{array}$ & $\begin{array}{c}0.0 \\
(0.00)\end{array}$ & $\begin{array}{c}0.0 \\
(0.00)\end{array}$ & $\begin{array}{c}0.0 \\
(0.00)\end{array}$ & $\begin{array}{c}0.4 \\
(0.04)\end{array}$ \\
\hline $\begin{array}{l}\text { Krascheninnikovia lanata } \\
\text { (winterfat) }\end{array}$ & $\begin{array}{c}0.0 \\
(0.00)\end{array}$ & $\begin{array}{c}0.0 \\
(0.00)\end{array}$ & $\begin{array}{c}0.0 \\
(0.00)\end{array}$ & $\begin{array}{c}0.0 \\
(0.00)\end{array}$ & $\begin{array}{c}0.0 \\
(0.00)\end{array}$ & $\begin{array}{c}0.2 \\
(0.02)\end{array}$ & $\begin{array}{c}0.0 \\
(0.00)\end{array}$ \\
\hline $\begin{array}{l}\text { Picrothamnus desertorum } \\
\text { (bud sagebrush) }\end{array}$ & $\begin{array}{c}0.0 \\
(0.00)\end{array}$ & $\begin{array}{c}0.1 \\
(0.01)\end{array}$ & $\begin{array}{c}0.1 \\
(0.01)\end{array}$ & $\begin{array}{c}0.0 \\
(0.00)\end{array}$ & $\begin{array}{c}0.0 \\
(0.00)\end{array}$ & $\begin{array}{c}0.0 \\
(0.00)\end{array}$ & $\begin{array}{c}0.0 \\
(0.00)\end{array}$ \\
\hline \multicolumn{8}{|l|}{ Grasses } \\
\hline $\begin{array}{l}\text { Achnatherum hymenoides } \\
\text { (Indian ricegrass) }\end{array}$ & $\begin{array}{c}4.8 \\
(0.45)\end{array}$ & $\begin{array}{c}3.2 \\
(0.30)\end{array}$ & $\begin{array}{c}2.1 \\
(0.20)\end{array}$ & $\begin{array}{c}1.0 \\
(0.09)\end{array}$ & $\begin{array}{c}0.4 \\
(0.04)\end{array}$ & $\begin{array}{c}0.3 \\
(0.03)\end{array}$ & $\begin{array}{l}1.7 \\
(0.16)\end{array}$ \\
\hline $\begin{array}{l}\text { Elymus elymoides } \\
\text { (squirreltail) }\end{array}$ & $\begin{array}{c}2.2 \\
(0.20)\end{array}$ & $\begin{array}{c}0.3 \\
(0.03)\end{array}$ & $\begin{array}{c}0.8 \\
(0.07)\end{array}$ & $\begin{array}{c}0.4 \\
(0.04)\end{array}$ & $\begin{array}{c}0.1 \\
(0.01)\end{array}$ & $\begin{array}{c}0.6 \\
(0.06)\end{array}$ & $\begin{array}{c}0.1 \\
(0.01)\end{array}$ \\
\hline $\begin{array}{l}\text { Pleuraphis jamesii } \\
\text { (galleta) }\end{array}$ & $\begin{array}{c}0.0 \\
(0.00)\end{array}$ & $\begin{array}{c}0.0 \\
(0.00)\end{array}$ & $\begin{array}{c}0.0 \\
(0.00)\end{array}$ & $\begin{array}{c}0.1 \\
(0.01)\end{array}$ & $\begin{array}{c}0.0 \\
(0.00)\end{array}$ & $\begin{array}{c}0.0 \\
(0.00)\end{array}$ & $\begin{array}{c}0.0 \\
(0.00)\end{array}$ \\
\hline \multicolumn{8}{|l|}{ Summary by Life-form } \\
\hline Shrubs & $\begin{array}{c}0.7 \\
(0.07)\end{array}$ & $\begin{array}{c}1.1 \\
(0.10)\end{array}$ & $\begin{array}{c}1.5 \\
(0.14)\end{array}$ & $\begin{array}{c}1.1 \\
(0.11)\end{array}$ & $\begin{array}{c}1.4 \\
(0.13)\end{array}$ & $\begin{array}{c}0.7 \\
(0.07)\end{array}$ & $\begin{array}{c}0.5 \\
(0.05)\end{array}$ \\
\hline Grasses & $\begin{array}{c}7.1 \\
(0.66)\end{array}$ & $\begin{array}{c}3.6 \\
(0.33)\end{array}$ & $\begin{array}{c}2.9 \\
(0.027)\end{array}$ & $\begin{array}{c}1.6 \\
(0.14)\end{array}$ & $\begin{array}{c}0.5 \\
(0.05)\end{array}$ & $\begin{array}{c}0.9 \\
(0.08)\end{array}$ & $\begin{array}{c}1.9 \\
(0.18)\end{array}$ \\
\hline Forbs & $\begin{array}{l}10.2 \\
(0.94)\end{array}$ & $\begin{array}{c}0.4 \\
(0.04)\end{array}$ & $\begin{array}{c}1.3 \\
(0.12)\end{array}$ & $\begin{array}{c}13.5 \\
(1.25)\end{array}$ & $\begin{array}{c}56.4 \\
(5.24)\end{array}$ & $\begin{array}{c}14.6 \\
(1.36)\end{array}$ & $\begin{array}{c}3.4 \\
(0.32)\end{array}$ \\
\hline Total & $\begin{array}{c}18.0 \\
(1.67)\end{array}$ & $\begin{array}{c}5.0 \\
(0.47)\end{array}$ & $\begin{array}{c}5.7 \\
(0.53)\end{array}$ & $\begin{array}{c}16.2 \\
(1.50)\end{array}$ & $\begin{array}{c}58.4 \\
(5.42)\end{array}$ & $\begin{array}{c}16.2 \\
(1.50)\end{array}$ & $\begin{array}{c}5.9 \\
(0.55)\end{array}$ \\
\hline
\end{tabular}

\subsubsection{CAU 400-Bomblet Pit}

The Bomblet Pit located near the bottoms of cactus flat on the TTR was seeded in the fall of 1997. The site prior to restoration efforts was heavily disturbed and dominated by Halogeton glomeratus (halogeton). This site, like the other closure sites on the TTR, was fenced to protect young seedlings and plants from horses, antelope, and rabbits. 
The first few years after revegetation at the Bomblet Pit site, plant cover ranged from 16-19 percent and was always higher than on the adjacent undisturbed reference area (Table 8-3). In 2003, cover decreased to 10 percent and continued below 10 percent for the next 2 years. These declines in plant cover were during a period of consecutive years of below average rainfall. The composition of the cover also changed. The first few years it was a mix of shrubs and grasses. But the grasses apparently were not able to survive the drought years and have not reestablished on the site since then (2000). Shrubs make up all of the 17.5-percent plant cover recorded this year, which is the highest it has been since 2002. There were a number of annual forbs found on the site in 2005 and comprised about 30 percent of the total cover, but this year, like years prior to 2005 , forbs were not abundant and contribute little, if any, to the overall plant cover.

Table 8-3. Plant cover on CAU 400-Bomblet Pit.

\begin{tabular}{lccccccc}
\hline & \multicolumn{7}{c}{ Percent Plant Cover } \\
& $\mathbf{2 0 0 0}$ & $\mathbf{2 0 0 2}$ & $\mathbf{2 0 0 3}$ & $\mathbf{2 0 0 4}$ & $\mathbf{2 0 0 5}$ & $\mathbf{2 0 0 6}$ & Reference \\
\hline Shrub & 15.8 & 18.8 & 10.0 & 7.5 & 8.8 & 17.5 & 10.0 \\
Grass & 2.6 & 0.0 & 0.0 & 0.0 & 0.0 & 0.0 & 1.3 \\
Forbs/Annuals & $\underline{0.0}$ & $\underline{0.0}$ & $\underline{0.0}$ & $\underline{0.0}$ & $\underline{3.8}$ & $\underline{0.0}$ & $\underline{0.0}$ \\
Total Plant Cover & 18.4 & 18.8 & 10.0 & 7.5 & 12.5 & 17.5 & 11.3 \\
& & & & & & & \\
Bare Ground & 63.2 & 61.3 & 73.8 & 78.8 & 72.5 & 62.5 & 58.8 \\
Litter & 18.4 & 20.0 & 16.3 & 13.8 & 15.0 & 20.0 & 30.0 \\
\hline
\end{tabular}

The density of perennial shrubs and grasses has not changed significantly the last three years. This year there was an increase in the number of shrubs and, for the first time since 2003, A. hymenoides was found on the site (Table 8-4). Atriplex confertifolia (shadscale) is still the most abundant shrub on the site, but there was an increase in the number of Picrothamnus desertorum (bud sagebrush) this year. K. lanata, once present at the site, has been absent for the last 3 years. P. desertorum, A. confertifolia, and K. lanata are the primary shrub species on the reference area. No annual forbs were recorded this year.

Overall, plant cover exceeded the amount of cover on the reference area this year like it has many of the years since it was revegetated. The 17.5-percent shrub cover this year is the second highest amount of cover at this site and is almost twice what it is on the reference area; however, grass cover continues to be lacking. Perennial plant density at the Bomblet Pit continues at around 6 plants $/ \mathrm{m}^{2}\left(0.6 \mathrm{plants} / \mathrm{ft}^{2}\right)$, which is higher than the density measured on the reference area. There were no forbs this year and, as previously mentioned, the wide fluctuations in forb densities make it a less-than-optimum means of measuring reclamation success. H. glomeratus, a noxious weed that dominated the area prior to closure, still does not appear to be a problem. After reaching a maximum density of $27.4 \mathrm{plants} / \mathrm{m}^{2}\left(2.50 \mathrm{plants} / \mathrm{ft}^{2}\right)$ in 1999 , the density of H. glomeratus declined to 0.1 plants $/ \mathrm{m}^{2}$ from 2002 to 2004 and has not been found on the site the last 2 years. 
Table 8-4. Plant density at CAU 400-Bomblet Pit.

\begin{tabular}{|c|c|c|c|c|c|c|c|}
\hline \multirow[b]{2}{*}{ Species } & \multicolumn{7}{|c|}{ Plants $/ \mathrm{m}^{2}$ with plants $/ \mathrm{ft}^{2}$ in parentheses } \\
\hline & 2000 & 2002 & 2003 & 2004 & 2005 & 2006 & Reference \\
\hline \multicolumn{8}{|l|}{ Shrubs } \\
\hline $\begin{array}{l}\text { Atriplex canescens } \\
\text { (fourwing saltbush) }\end{array}$ & $\begin{array}{c}0.5 \\
(0.04)\end{array}$ & $\begin{array}{c}0.3 \\
((0.03)\end{array}$ & $\begin{array}{c}0.2 \\
(0.01)\end{array}$ & $\begin{array}{c}0.2 \\
(0.01)\end{array}$ & $\begin{array}{c}0.1 \\
(0.01)\end{array}$ & $\begin{array}{c}0.0 \\
(0.00)\end{array}$ & $\begin{array}{c}0.0 \\
(0.00)\end{array}$ \\
\hline $\begin{array}{l}\text { Atriplex confertifolia } \\
\text { (shadscale) }\end{array}$ & $\begin{array}{l}6.8 \\
(0.63)\end{array}$ & $\begin{array}{c}6.5 \\
(0.60)\end{array}$ & $\begin{array}{c}6.4 \\
(0.59)\end{array}$ & $\begin{array}{l}5.3 \\
(0.49)\end{array}$ & $\begin{array}{c}4.7 \\
(0.44)\end{array}$ & $\begin{array}{c}4.8 \\
(0.44)\end{array}$ & $\begin{array}{c}1.2 \\
(0.11)\end{array}$ \\
\hline $\begin{array}{l}\text { Krascheninnikovia lanata } \\
\text { (winterfat) }\end{array}$ & $\begin{array}{c}0.3 \\
(0.02)\end{array}$ & $\begin{array}{c}0.0 \\
(0.00)\end{array}$ & $\begin{array}{c}0.1 \\
(0.00)\end{array}$ & $\begin{array}{c}0.0 \\
(0.00)\end{array}$ & $\begin{array}{c}0.0 \\
(0.00)\end{array}$ & $\begin{array}{c}0.0 \\
(0.00)\end{array}$ & $\begin{array}{c}0.3 \\
(0.02)\end{array}$ \\
\hline $\begin{array}{l}\text { Picrothamnus desertorum } \\
\text { (bud sagebrush) }\end{array}$ & $\begin{array}{l}3.8 \\
(0.35)\end{array}$ & $\begin{array}{c}2.5 \\
(0.23)\end{array}$ & $\begin{array}{l}2.6 \\
(0.24)\end{array}$ & $\begin{array}{c}0.8 \\
(0.07)\end{array}$ & $\begin{array}{c}0.9 \\
(0.08)\end{array}$ & $\begin{array}{c}1.7 \\
(0.16)\end{array}$ & $\begin{array}{c}2.4 \\
(0.22)\end{array}$ \\
\hline \multicolumn{8}{|l|}{ Grasses } \\
\hline $\begin{array}{l}\text { Achnatherum hymenoides } \\
\text { (Indian ricegrass) }\end{array}$ & $\begin{array}{c}2.5 \\
(0.23)\end{array}$ & $\begin{array}{c}0.2 \\
(0.01)\end{array}$ & $\begin{array}{c}0.4 \\
(0.04)\end{array}$ & $\begin{array}{c}0.0 \\
(0.00)\end{array}$ & $\begin{array}{c}0.0 \\
(0.00)\end{array}$ & $\begin{array}{c}0.1 \\
(0.00)\end{array}$ & $\begin{array}{c}0.1 \\
(0.00)\end{array}$ \\
\hline $\begin{array}{l}\text { Elymus elymoides } \\
\text { (squirreltail) }\end{array}$ & $\begin{array}{c}3.1 \\
(0.29)\end{array}$ & $\begin{array}{c}0.0 \\
(0.00)\end{array}$ & $\begin{array}{c}0.0 \\
(0.00)\end{array}$ & $\begin{array}{c}0.0 \\
(0.00)\end{array}$ & $\begin{array}{c}0.0 \\
(0.00)\end{array}$ & $\begin{array}{c}0.0 \\
(0.00)\end{array}$ & $\begin{array}{c}0.0 \\
(0.00)\end{array}$ \\
\hline $\begin{array}{l}\text { Pleuraphis jamesii } \\
\text { (galleta) }\end{array}$ & $\begin{array}{c}0.0 \\
(0.00)\end{array}$ & $\begin{array}{c}0.0 \\
(0.00)\end{array}$ & $\begin{array}{c}0.0 \\
(0.00)\end{array}$ & $\begin{array}{c}0.0 \\
(0.00)\end{array}$ & $\begin{array}{l}0.0 \\
(0.00)\end{array}$ & $\begin{array}{c}0.0 \\
(0.00)\end{array}$ & $\begin{array}{c}0.0 \\
(0.00)\end{array}$ \\
\hline \multicolumn{8}{|l|}{ Summary by Life-form } \\
\hline Shrubs & $\begin{array}{c}11.3 \\
(1.05)\end{array}$ & $\begin{array}{c}9.2 \\
(0.85)\end{array}$ & $\begin{array}{c}9.2 \\
(0.85)\end{array}$ & $\begin{array}{c}6.2 \\
(0.58)\end{array}$ & $\begin{array}{c}5.7 \\
(0.53)\end{array}$ & $\begin{array}{c}6.5 \\
(0.60)\end{array}$ & $\begin{array}{c}3.8 \\
(0.35)\end{array}$ \\
\hline Grasses & $\begin{array}{c}5.6 \\
(0.52)\end{array}$ & $\begin{array}{c}0.2 \\
(0.01)\end{array}$ & $\begin{array}{c}0.4 \\
(0.04)\end{array}$ & $\begin{array}{c}0.0 \\
(0.00)\end{array}$ & $\begin{array}{c}0.0 \\
(0.00)\end{array}$ & $\begin{array}{c}0.1 \\
(0.00)\end{array}$ & $\begin{array}{c}0.1 \\
(0.00)\end{array}$ \\
\hline Forbs & $\begin{array}{c}5.4 \\
(0.50) \\
\end{array}$ & $\begin{array}{c}0.3 \\
(0.02) \\
\end{array}$ & $\begin{array}{c}0.1 \\
(0.00) \\
\end{array}$ & $\begin{array}{c}1.1 \\
(0.10) \\
\end{array}$ & $\begin{array}{c}56.0 \\
(5.20) \\
\end{array}$ & $\begin{array}{c}0.0 \\
(0.00) \\
\end{array}$ & $\begin{array}{c}0.5 \\
(0.04) \\
\end{array}$ \\
\hline Total Plant Density & $\begin{array}{c}22.3 \\
(2.07)\end{array}$ & $\begin{array}{c}9.6 \\
(0.89)\end{array}$ & $\begin{array}{c}9.7 \\
(0.90)\end{array}$ & $\begin{array}{c}7.3 \\
(0.67)\end{array}$ & $\begin{array}{c}61.7 \\
(5.73)\end{array}$ & $\begin{array}{c}6.5 \\
(0.60)\end{array}$ & $\begin{array}{c}4.3 \\
(0.39)\end{array}$ \\
\hline
\end{tabular}

The first couple years after revegetation there were an abundance of grasses, many more than on the adjacent reference area. Since then grasses have gradually declined. The reappearance of $A$. hymenoides this year is encouraging. With favorable growing conditions in the future, native grasses like A. hymenoides, may become established and contribute more to overall plant cover and density. Grasses are uncommon on the reference area, but not absent as they have been on the restoration site. Shrubs have become well established as indicated by higher cover values and densities than shrubs on the reference area.

\subsubsection{CAU 426-Cactus Springs Waste Trenches}

The Cactus Springs Waste Trench site is located on the eastern slope of the Cactus Range just south and east of Cactus Peak. The site is about $200 \mathrm{~m}(656 \mathrm{ft})$ higher than the other closure sites. A staging area and the waste trench cover cap were revegetated in the fall of 1997 . Results of this year's monitoring for the staging area are reported in this section. 
Combined shrub and grass cover continues to be very good on the staging area at the Cactus Springs Waste Trenches site. Shrub cover is about what it was last year, which is about as high as it has been the last 6 years. Grass cover decreased to 10.8 percent from a record high of 17.1 percent last year (Table 8-5). There was not any grass cover on the reference site this year and in previous years it has ranged between 1 and 2 percent, much less than has been recorded on the staging area. The lack of grasses on the reference area may be because of the proximity of the site to Cactus Springs, which is commonly used by wild horses and other grazing animals. Forb cover dropped from the record amount last year to about 2 percent (Table 8-5). There was the same amount of forb cover on the reference site.

Table 8-5. Plant cover on CAU 426-Cactus Springs Waste Trenches: Staging area.

\begin{tabular}{lccccccc}
\hline & \multicolumn{7}{c}{ Percent Plant Cover } \\
& $\mathbf{2 0 0 0}$ & $\mathbf{2 0 0 2}$ & $\mathbf{2 0 0 3}$ & $\mathbf{2 0 0 4}$ & $\mathbf{2 0 0 5}$ & $\mathbf{2 0 0 6}$ & Reference \\
\hline Shrub & 0.8 & 5.0 & 2.5 & 3.3 & 5.1 & 5.0 & 10.8 \\
Grass & 5.8 & 12.5 & 6.7 & 10.8 & 17.1 & 10.8 & 0.0 \\
Forbs/Annuals & $\underline{0.0}$ & $\underline{1.7}$ & $\underline{5.0}$ & $\underline{2.5}$ & $\underline{10.3}$ & $\underline{1.7}$ & $\underline{1.7}$ \\
Total Plant Cover & 6.7 & 19.2 & 14.2 & 16.7 & 32.5 & 17.5 & 12.5 \\
Bare Ground & & & & & & & \\
Litter & 50.0 & 42.5 & 50.0 & 59.2 & 47.0 & 50.0 & 75.0 \\
\hline
\end{tabular}

The density of shrubs on the staging area has been close to 0.1 plants $/ \mathrm{m}^{2}\left(0.01 \mathrm{ft}^{2}\right)$ for the last 5 years. The density of grasses has varied over the years but the 3.9 plants $/ \mathrm{m}^{2}\left(0.36\right.$ plants $\left./ \mathrm{ft}^{2}\right)$ this year is only less than the number recorded last year during above normal precipitation, and in 2000 when there was an abundance of young seedlings. The number of annual forbs also declined from 2005 to 2006 but still more than recorded between 2002 and 2004. Of particular concern has been the presence of an annual noxious weed, H. glomeratus. Of the 7.3 annual plants $/ \mathrm{m}^{2}\left(0.68\right.$ plants/ $\left./ \mathrm{ft}^{2}\right)$ recorded this year (Table 8-6), only 1.4 plants were halogeton, which is lower than in previous years.

Ephedra nevadensis (Nevada jointfir) is the most common shrub found on the site. Chrysothamnus viscidiflorus (Douglas rabbitbrush) is also present, but at lower densities. The presence of $A$. confertifolia and Ericameria nauseosa (rubber rabbitbrush) has been sporadic over the years but both were found on the site this year. No A. canescens or K. lanata were found this year.

E. elymoides is the most common grass found on the staging area, followed by A. hymenoides and Pleuraphis jamesii (galleta). Plant densities for E. elymoides and A. hymenoides were lower than last year, but there was an increase in $P$. jamesii. Overall, grass density this year, although 50 percent less than in 2005 , is still higher than recorded in the 3 years prior to 2005 .

This is the only site where the grass cover and density are higher than they are for shrubs. Usually shrubs are several times more abundant than grasses but, on the staging area at the Cactus Springs Waste Trench, grass cover is double what shrub cover is and there are more than twice as many grasses $/ \mathrm{m}^{2}$ as there are shrubs. This site was disturbed prior to closure activities and H. glomeratus, a noxious weed, occupied much of the area. Since revegetation efforts occurred, the density of halogeton has decreased from 15 plants $/ \mathrm{m}^{2}$ in 2000 to 1.4 plants $/ \mathrm{m}^{2}\left(0.13\right.$ plants $\left./ \mathrm{ft}^{2}\right)$ this year. The abundance of this species is usually kept in check by the presence of native plant species and the absence of new soil disturbances. 
Table 8-6. Plant density at CAU 426-Cactus Springs Waste Trenches: Staging area.

\begin{tabular}{|c|c|c|c|c|c|c|c|}
\hline \multirow[b]{2}{*}{ Species } & \multicolumn{7}{|c|}{ Plants $/ \mathrm{m}^{2}$ with plants $/ \mathrm{ft}^{2}$ in parentheses } \\
\hline & 2000 & 2002 & 2003 & 2004 & 2005 & 2006 & Reference \\
\hline \multicolumn{8}{|l|}{ Shrubs } \\
\hline $\begin{array}{l}\text { Artemisia nova } \\
\quad \text { (black sagebrush) }\end{array}$ & $\begin{array}{c}0.0 \\
(0.00)\end{array}$ & $\begin{array}{c}0.1 \\
(0.00)\end{array}$ & $\begin{array}{c}0.0 \\
(0.00)\end{array}$ & $\begin{array}{c}0.0 \\
(0.00)\end{array}$ & $\begin{array}{c}0.0 \\
(0.00)\end{array}$ & $\begin{array}{c}0.0 \\
(0.00)\end{array}$ & $\begin{array}{c}0.8 \\
(0.07)\end{array}$ \\
\hline $\begin{array}{l}\text { Atriplex canescens } \\
\text { (fourwing saltbush) }\end{array}$ & $\begin{array}{c}0.1 \\
(0.01)\end{array}$ & $\begin{array}{c}0.0 \\
(0.00)\end{array}$ & $\begin{array}{c}0.0 \\
(0.00)\end{array}$ & $\begin{array}{c}0.0 \\
(0.00)\end{array}$ & $\begin{array}{c}0.1 \\
(0.01)\end{array}$ & $\begin{array}{c}0.0 \\
(0.00)\end{array}$ & $\begin{array}{c}0.0 \\
(0.00)\end{array}$ \\
\hline $\begin{array}{l}\text { Atriplex confertifolia } \\
\text { (shadscale) }\end{array}$ & $\begin{array}{c}0.1 \\
(0.01)\end{array}$ & $\begin{array}{c}0.0 \\
(0.00)\end{array}$ & $\begin{array}{c}0.0 \\
(0.00)\end{array}$ & $\begin{array}{c}0.1 \\
(0.01)\end{array}$ & $\begin{array}{c}0.0 \\
(0.00)\end{array}$ & $\begin{array}{c}0.1 \\
(0.01)\end{array}$ & $\begin{array}{c}0.3 \\
(0.02)\end{array}$ \\
\hline $\begin{array}{l}\text { Chrysothamnus viscidiflorus } \\
\text { (Douglas' rabbitbrush) }\end{array}$ & $\begin{array}{c}0.1 \\
(0.01)\end{array}$ & $\begin{array}{c}0.1 \\
(0.01)\end{array}$ & $\begin{array}{c}0.2 \\
(0.02)\end{array}$ & $\begin{array}{c}0.1 \\
(0.01)\end{array}$ & $\begin{array}{c}0.2 \\
(0.02)\end{array}$ & $\begin{array}{c}0.1 \\
(0.01)\end{array}$ & $\begin{array}{c}0.0 \\
(0.00)\end{array}$ \\
\hline $\begin{array}{l}\text { Ephedra nevadensis } \\
\text { (Nevada jointfir) }\end{array}$ & $\begin{array}{c}0.3 \\
(0.02)\end{array}$ & $\begin{array}{c}0.2 \\
(0.02)\end{array}$ & $\begin{array}{c}0.3 \\
(0.02)\end{array}$ & $\begin{array}{c}0.1 \\
(0.01)\end{array}$ & $\begin{array}{c}0.3 \\
(0.02)\end{array}$ & $\begin{array}{c}0.4 \\
(0.03)\end{array}$ & $\begin{array}{c}0.0 \\
(0.00)\end{array}$ \\
\hline $\begin{array}{r}\text { Ericameria nauseosa } \\
\text { (rubber rabbitbrush) }\end{array}$ & $\begin{array}{c}0.1 \\
(0.01)\end{array}$ & $\begin{array}{c}0.0 \\
(0.00)\end{array}$ & $\begin{array}{c}0.1 \\
(0.01)\end{array}$ & $\begin{array}{c}0.1 \\
(0.01)\end{array}$ & $\begin{array}{c}0.0 \\
(0.00)\end{array}$ & $\begin{array}{c}0.1 \\
(0.01)\end{array}$ & $\begin{array}{c}0.0 \\
(0.00)\end{array}$ \\
\hline $\begin{array}{l}\text { Krascheninnikovia lanata } \\
\text { (winterfat) }\end{array}$ & $\begin{array}{c}0.0 \\
(0.00)\end{array}$ & $\begin{array}{c}0.0 \\
(0.00)\end{array}$ & $\begin{array}{c}0.0 \\
(0.00)\end{array}$ & $\begin{array}{c}0.0 \\
(0.00)\end{array}$ & $\begin{array}{c}0.1 \\
(0.01)\end{array}$ & $\begin{array}{c}0.0 \\
(0.00)\end{array}$ & $\begin{array}{l}0.0 \\
(0.00)\end{array}$ \\
\hline $\begin{array}{l}\text { Picrothamnus desertorum } \\
\text { (bud sagebrush) }\end{array}$ & $\begin{array}{c}0.0 \\
(0.00)\end{array}$ & $\begin{array}{c}0.1 \\
(0.01)\end{array}$ & $\begin{array}{c}0.0 \\
(0.00)\end{array}$ & $\begin{array}{c}0.0 \\
(0.00)\end{array}$ & $\begin{array}{c}0.0 \\
(0.00)\end{array}$ & $\begin{array}{c}0.0 \\
(0.00)\end{array}$ & $\begin{array}{c}0.4 \\
(0.03)\end{array}$ \\
\hline \multicolumn{8}{|l|}{ Grasses } \\
\hline $\begin{array}{l}\text { Achnatherum hymenoides } \\
\text { (Indian ricegrass) }\end{array}$ & $\begin{array}{c}1.4 \\
(0.13)\end{array}$ & $\begin{array}{c}0.6 \\
(0.06)\end{array}$ & $\begin{array}{c}0.7 \\
(0.07)\end{array}$ & $\begin{array}{c}0.4 \\
(0.03)\end{array}$ & $\begin{array}{c}1.3 \\
(0.12)\end{array}$ & $\begin{array}{c}0.6 \\
(0.06)\end{array}$ & $\begin{array}{c}0.1 \\
(0.00)\end{array}$ \\
\hline $\begin{array}{l}\text { Elymus elymoides } \\
\text { (squirreltail) }\end{array}$ & $\begin{array}{c}5.2 \\
(0.48)\end{array}$ & $\begin{array}{l}2.9 \\
(0.27)\end{array}$ & $\begin{array}{c}0.6 \\
(0.06)\end{array}$ & $\begin{array}{c}1.9 \\
(0.18)\end{array}$ & $\begin{array}{c}5.1 \\
(0.47)\end{array}$ & $\begin{array}{c}3.1 \\
(0.28)\end{array}$ & $\begin{array}{c}0.1 \\
(0.01)\end{array}$ \\
\hline $\begin{array}{l}\text { Pleuraphis jamesii } \\
\text { (galleta) }\end{array}$ & $\begin{array}{c}0.2 \\
(0.02)\end{array}$ & $\begin{array}{c}0.1 \\
(0.01)\end{array}$ & $\begin{array}{c}0.0 \\
(0.00)\end{array}$ & $\begin{array}{c}0.3 \\
(0.03)\end{array}$ & $\begin{array}{c}0.0 \\
(0.00)\end{array}$ & $\begin{array}{c}0.2 \\
(0.02)\end{array}$ & $\begin{array}{l}3.0 \\
(0.28)\end{array}$ \\
\hline \multicolumn{8}{|l|}{ Summary by Life-form } \\
\hline Shrubs & $\begin{array}{c}0.7 \\
(0.06)\end{array}$ & $\begin{array}{c}0.5 \\
(0.05)\end{array}$ & $\begin{array}{c}0.6 \\
(0.06)\end{array}$ & $\begin{array}{c}0.5 \\
(0.04)\end{array}$ & $\begin{array}{c}0.6 \\
(0.05)\end{array}$ & $\begin{array}{c}0.6 \\
(0.05)\end{array}$ & $\begin{array}{c}1.5 \\
(0.13)\end{array}$ \\
\hline Grasses & $\begin{array}{c}6.8 \\
(0.63)\end{array}$ & $\begin{array}{c}3.5 \\
(0.33)\end{array}$ & $\begin{array}{c}1.6 \\
(0.15)\end{array}$ & $\begin{array}{l}2.6 \\
(0.24\end{array}$ & $\begin{array}{c}6.3 \\
(0.59)\end{array}$ & $\begin{array}{c}3.9 \\
(0.36)\end{array}$ & $\begin{array}{c}3.8 \\
(0.35)\end{array}$ \\
\hline Forbs/Annuals & $\begin{array}{r}16.9 \\
(1.57) \\
\end{array}$ & $\begin{array}{r}1.8 \\
(0.17) \\
\end{array}$ & $\begin{array}{r}3.9 \\
(0.36) \\
\end{array}$ & $\begin{array}{c}3.2 \\
(0.30) \\
\end{array}$ & $\begin{array}{r}16.6 \\
(1.54) \\
\end{array}$ & $\begin{array}{r}7.3 \\
(0.68) \\
\end{array}$ & $\begin{array}{r}1.6 \\
(0.14) \\
\end{array}$ \\
\hline Total Plant Density & $\begin{array}{c}24.4 \\
(2.26)\end{array}$ & $\begin{array}{c}5.8 \\
(0.54)\end{array}$ & $\begin{array}{c}6.1 \\
(0.56)\end{array}$ & $\begin{array}{c}6.3 \\
(0.59)\end{array}$ & $\begin{array}{c}23.5 \\
(2.18)\end{array}$ & $\begin{array}{c}11.7 \\
(1.09)\end{array}$ & $\begin{array}{c}6.8 \\
(0.63)\end{array}$ \\
\hline
\end{tabular}

\subsubsection{CAU 404-Rollercoaster Sewage Lagoons}

The Rollercoaster Sewage Lagoon closure site covers approximately 2.2 ha (5.5 ac). Three-fourths of the site is the staging area used during remediation activities and was revegetated along with the cover cap in the fall of 1997. This site is located midslope between the playa bottoms and the foothills of the Cactus Range.

Overall, plant cover on the staging area of the Rollercoaster Sewage Lagoon site decreased slightly from 2005 to 2006. The only decrease was in annual forb cover. Shrub cover remained about the same, whereas grass cover more than doubled from 2005 to 2006 (Table 8-7). 
Table 8-7. Plant cover on CAU 404-Rollercoaster Sewage Lagoons: Staging area.

\begin{tabular}{lccccccc}
\hline & \multicolumn{7}{c}{ Percent Plant Cover } \\
& $\mathbf{2 0 0 0}$ & $\mathbf{2 0 0 2}$ & $\mathbf{2 0 0 3}$ & $\mathbf{2 0 0 4}$ & $\mathbf{2 0 0 5}$ & $\mathbf{2 0 0 6}$ & Reference \\
\hline Shrub & 9.0 & 18.5 & 13.6 & 17.0 & 19.5 & 19.4 & 11.1 \\
Grass & 3.5 & 0.5 & 0.5 & 0.0 & 0.5 & 1.1 & 2.8 \\
Forbs/Annuals & $\underline{0.0}$ & $\underline{0.0}$ & $\underline{0.0}$ & $\underline{0.0}$ & $\underline{3.5}$ & $\underline{1.1}$ & $\underline{3.3}$ \\
Total Plant Cover & 12.5 & 19.0 & 14.1 & 17.0 & 23.5 & 21.7 & 17.2 \\
Bare Ground & & & & & & & \\
Litter & 56.5 & 53.0 & 69.3 & 61.5 & 69.0 & 56.1 & 55.0 \\
\hline
\end{tabular}

Both shrub and grass cover are nearly the highest they have been in the last five years. Annual forb cover was about a third of what it was last year. Last year was the first and only year that forbs contributed to overall plant cover.

The decrease in overall plant density from 2005 to 2006 is misleading because 25 of the 32 plants $/ \mathrm{m}^{2}$ reported for last year were annual forbs. This year there were only 0.8 forbs or annuals $/ \mathrm{m}^{2}\left(0.08 \mathrm{plants} / \mathrm{ft}^{2}\right)$, which is the typical contribution of annual forbs. Shrub and grass density, all perennial plants, actually increased from 6.5 plants $/ \mathrm{m}^{2}\left(0.60\right.$ plants $\left./ \mathrm{ft}^{2}\right)$ in 2005 to 7.3 plants $/ \mathrm{m}^{2}\left(0.68\right.$ plants $\left./ \mathrm{ft}^{2}\right)$ this year (Table $\left.8-8\right)$. There was a slight decrease in the density of grasses, but shrubs increased from 6.2 plants $/ \mathrm{m}^{2}\left(0.60\right.$ plants $\left./ \mathrm{ft}^{2}\right)$ to 7.1 plants $/ \mathrm{m}^{2}\left(0.66 \mathrm{plants} / \mathrm{ft}^{2}\right)$, which is the first time shrub density has increased since the site was revegetated (Figure 8-1).

$P$. desertorum increased from 0.6 plants $/ \mathrm{m}^{2}\left(0.06\right.$ plants $\left./ \mathrm{ft}^{2}\right)$ in 2005 to $1.6 \mathrm{plants} / \mathrm{m}^{2}\left(0.15 \mathrm{plants} / \mathrm{ft}^{2}\right)$ this year. This is very encouraging because this species has steadily decreased since 2000 although it is a major constituent of the native vegetation surrounding the site. Grass density is usually made up of one species, P jamesii. The density of P. jamesii was lower this year than last; however, A. hymenoides, which decreased dramatically from 2000 to 2002 (Table 8-8), was again present. The density of annual forbs has fluctuated from 0.7 to 25 plants $/ \mathrm{m}^{2}$ ( 0.07 to 2.35 plants $\left./ \mathrm{ft}^{2}\right)$ over the last 6 years. H. glomeratus, a noxious weed, has been found on the staging area as well as in the native plant community. The density of $H$. glomeratus was 3.0 plants $/ \mathrm{m}^{2}\left(0.03\right.$ plants $\left./ \mathrm{ft}^{2}\right)$ the first year after revegetation, decreased to $0.5 \mathrm{plants} / \mathrm{m}^{2}\left(0.04\right.$ plants $\left./ \mathrm{ft}^{2}\right)$ the next year, showed a slight increase over the next 3 years to a high of 1.6 plants $/ \mathrm{m}^{2}\left(0.15\right.$ plants $\left./ \mathrm{ft}^{2}\right)$ in 2004 , decreased to 0.1 plants $/ \mathrm{m}^{2}\left(0.01\right.$ plants $\left./ \mathrm{ft}^{2}\right)$ in 2005 , and was not found on the site this year. The establishment of both perennial and annual native plants has been the best control measure for this noxious weed.

Overall, plant cover and plant density on the staging area at the Rollercoaster Sewage Lagoon site exceed the cover and density measured on the reference area this year. However, when considering individual lifeforms, shrub cover and density are about double what they are on the reference area. Grass cover and density, however, are well below the levels measured on the reference area. Grass cover on the staging area this year was only about 40 percent of what it was on the reference area and the density of grasses was barely 15 percent of that on the reference area. Shrub cover and density have been consistently higher than the reference area for the last several years, indicating that they have successfully established on the site. The increase in $P$. desertorum this year is very encouraging. This species is an important component of the native vegetation and had declined in density over the last few years. This is the first year the density of $P$ desertorum has increased. 
Table 8-8. Plant density at CAU 404-Rollercoaster Sewage Lagoons: Staging area.

\begin{tabular}{|c|c|c|c|c|c|c|c|}
\hline \multirow[b]{2}{*}{ Species } & \multicolumn{7}{|c|}{ Plants $/ \mathrm{m}^{2}$ with plants $/ \mathrm{ft}^{2}$ in parentheses } \\
\hline & 2000 & 2002 & 2003 & 2004 & 2005 & 2006 & Reference \\
\hline \multicolumn{8}{|l|}{ Shrubs } \\
\hline $\begin{array}{l}\text { Atriplex canescens } \\
\text { (fourwing saltbush) }\end{array}$ & $\begin{array}{c}0.3 \\
(0.03)\end{array}$ & $\begin{array}{c}0.2 \\
(0.02)\end{array}$ & $\begin{array}{c}0.1 \\
(0.01)\end{array}$ & $\begin{array}{c}0.1 \\
(0.01)\end{array}$ & $\begin{array}{c}0.1 \\
(0.01)\end{array}$ & $\begin{array}{c}0.0 \\
(0.00)\end{array}$ & $\begin{array}{l}0.0 \\
(0.00)\end{array}$ \\
\hline $\begin{array}{l}\text { Atriplex confertifolia } \\
\text { (shadscale) }\end{array}$ & $\begin{array}{l}10.0 \\
(0.93)\end{array}$ & $\begin{array}{c}6.9 \\
(0.64)\end{array}$ & $\begin{array}{c}5.5 \\
(0.51)\end{array}$ & $\begin{array}{c}5.4 \\
(0.50)\end{array}$ & $\begin{array}{c}5.4 \\
(0.50)\end{array}$ & $\begin{array}{c}5.3 \\
(0.50)\end{array}$ & $\begin{array}{c}0.8 \\
(0.07)\end{array}$ \\
\hline $\begin{array}{l}\text { Krascheninnikovia lanata } \\
\text { (winterfat) }\end{array}$ & $\begin{array}{c}0.0 \\
(0.00)\end{array}$ & $\begin{array}{c}0.1 \\
(0.01)\end{array}$ & $\begin{array}{c}0.1 \\
(0.01)\end{array}$ & $\begin{array}{c}0.1 \\
(0.01)\end{array}$ & $\begin{array}{c}0.1 \\
(0.01)\end{array}$ & $\begin{array}{c}0.1 \\
(0.01)\end{array}$ & $\begin{array}{c}0.1 \\
(0.01)\end{array}$ \\
\hline $\begin{array}{l}\text { Picrothamnus desertorum } \\
\text { (bud sagebrush) }\end{array}$ & $\begin{array}{c}1.7 \\
(0.16)\end{array}$ & $\begin{array}{c}1.2 \\
(0.11)\end{array}$ & $\begin{array}{c}0.8 \\
(0.07)\end{array}$ & $\begin{array}{c}0.6 \\
(0.06)\end{array}$ & $\begin{array}{c}0.6 \\
(0.06)\end{array}$ & $\begin{array}{c}1.6 \\
(0.15)\end{array}$ & $\begin{array}{l}2.6 \\
(0.24)\end{array}$ \\
\hline \multicolumn{8}{|l|}{ Grasses } \\
\hline $\begin{array}{l}\text { Achnatherum hymenoides } \\
\text { (Indian ricegrass) }\end{array}$ & $\begin{array}{c}2.5 \\
(0.23)\end{array}$ & $\begin{array}{c}0.5 \\
(0.04)\end{array}$ & $\begin{array}{c}0.0 \\
(0.00)\end{array}$ & $\begin{array}{c}0.1 \\
(0.01)\end{array}$ & $\begin{array}{c}0.0 \\
(0.00)\end{array}$ & $\begin{array}{c}0.1 \\
(0.01)\end{array}$ & $\begin{array}{c}0.3 \\
(0.03)\end{array}$ \\
\hline $\begin{array}{l}\text { Elymus elymoides } \\
\text { (squirreltail) }\end{array}$ & $\begin{array}{c}6.2 \\
(0.58)\end{array}$ & $\begin{array}{c}0.1 \\
(0.01)\end{array}$ & $\begin{array}{c}0.0 \\
(0.00)\end{array}$ & $\begin{array}{c}0.0 \\
(0.00)\end{array}$ & $\begin{array}{c}0.0 \\
(0.00)\end{array}$ & $\begin{array}{c}0.0 \\
(0.00)\end{array}$ & $\begin{array}{c}0.0 \\
(0.00)\end{array}$ \\
\hline $\begin{array}{l}\text { Dasyochloa pulchella } \\
\text { (low woolygrass) }\end{array}$ & $\begin{array}{c}0.0 \\
(0.00)\end{array}$ & $\begin{array}{c}0.0 \\
(0.00)\end{array}$ & $\begin{array}{c}0.0 \\
(0.00)\end{array}$ & $\begin{array}{c}0.0 \\
(0.00)\end{array}$ & $\begin{array}{c}0.0 \\
(0.00)\end{array}$ & $\begin{array}{c}0.0 \\
(0.00)\end{array}$ & $\begin{array}{c}0.3 \\
(0.03)\end{array}$ \\
\hline $\begin{array}{l}\text { Pleuraphis jamesii } \\
\text { (galleta) }\end{array}$ & $\begin{array}{c}0.8 \\
(0.07)\end{array}$ & $\begin{array}{c}0.3 \\
(0.03)\end{array}$ & $\begin{array}{c}0.2 \\
(0.02)\end{array}$ & $\begin{array}{c}0.1 \\
(0.01)\end{array}$ & $\begin{array}{c}0.2 \\
(0.02)\end{array}$ & $\begin{array}{c}0.1 \\
(0.01)\end{array}$ & $\begin{array}{c}0.8 \\
(0.08)\end{array}$ \\
\hline \multicolumn{8}{|l|}{ Summary by Life-form } \\
\hline Shrubs & $\begin{array}{c}12.1 \\
(1.12)\end{array}$ & $\begin{array}{c}8.4 \\
(0.78)\end{array}$ & $\begin{array}{c}6.4 \\
(0.60)\end{array}$ & $\begin{array}{c}6.2 \\
(0.58)\end{array}$ & $\begin{array}{c}6.2 \\
(0.58)\end{array}$ & $\begin{array}{c}7.1 \\
(0.66)\end{array}$ & $\begin{array}{c}3.4 \\
(0.32)\end{array}$ \\
\hline Grasses & $\begin{array}{c}9.5 \\
(0.88)\end{array}$ & $\begin{array}{c}0.9 \\
(0.08)\end{array}$ & $\begin{array}{c}0.3 \\
(0.03)\end{array}$ & $\begin{array}{c}0.2 \\
(0.02)\end{array}$ & $\begin{array}{c}0.3 \\
(0.03)\end{array}$ & $\begin{array}{c}0.2 \\
(0.02)\end{array}$ & $\begin{array}{c}1.4 \\
(0.13)\end{array}$ \\
\hline Forbs/Annuals & $\begin{array}{c}3.5 \\
(0.32) \\
\end{array}$ & $\begin{array}{c}0.7 \\
(0.07) \\
\end{array}$ & $\begin{array}{c}0.7 \\
(0.07) \\
\end{array}$ & $\begin{array}{c}1.9 \\
(0.18) \\
\end{array}$ & $\begin{array}{r}25.3 \\
(2.35) \\
\end{array}$ & $\begin{array}{c}0.8 \\
(0.08) \\
\end{array}$ & $\begin{array}{c}3.3 \\
(0.30) \\
\end{array}$ \\
\hline Total Plant Density & $\begin{array}{l}25.0 \\
(2.32)\end{array}$ & $\begin{array}{l}10.0 \\
(0.93)\end{array}$ & $\begin{array}{c}7.4 \\
(0.68)\end{array}$ & $\begin{array}{c}8.3 \\
(0.77)\end{array}$ & $\begin{array}{c}31.8 \\
(2.95)\end{array}$ & $\begin{array}{c}8.1 \\
(0.75)\end{array}$ & $\begin{array}{c}8.1 \\
(0.76)\end{array}$ \\
\hline
\end{tabular}




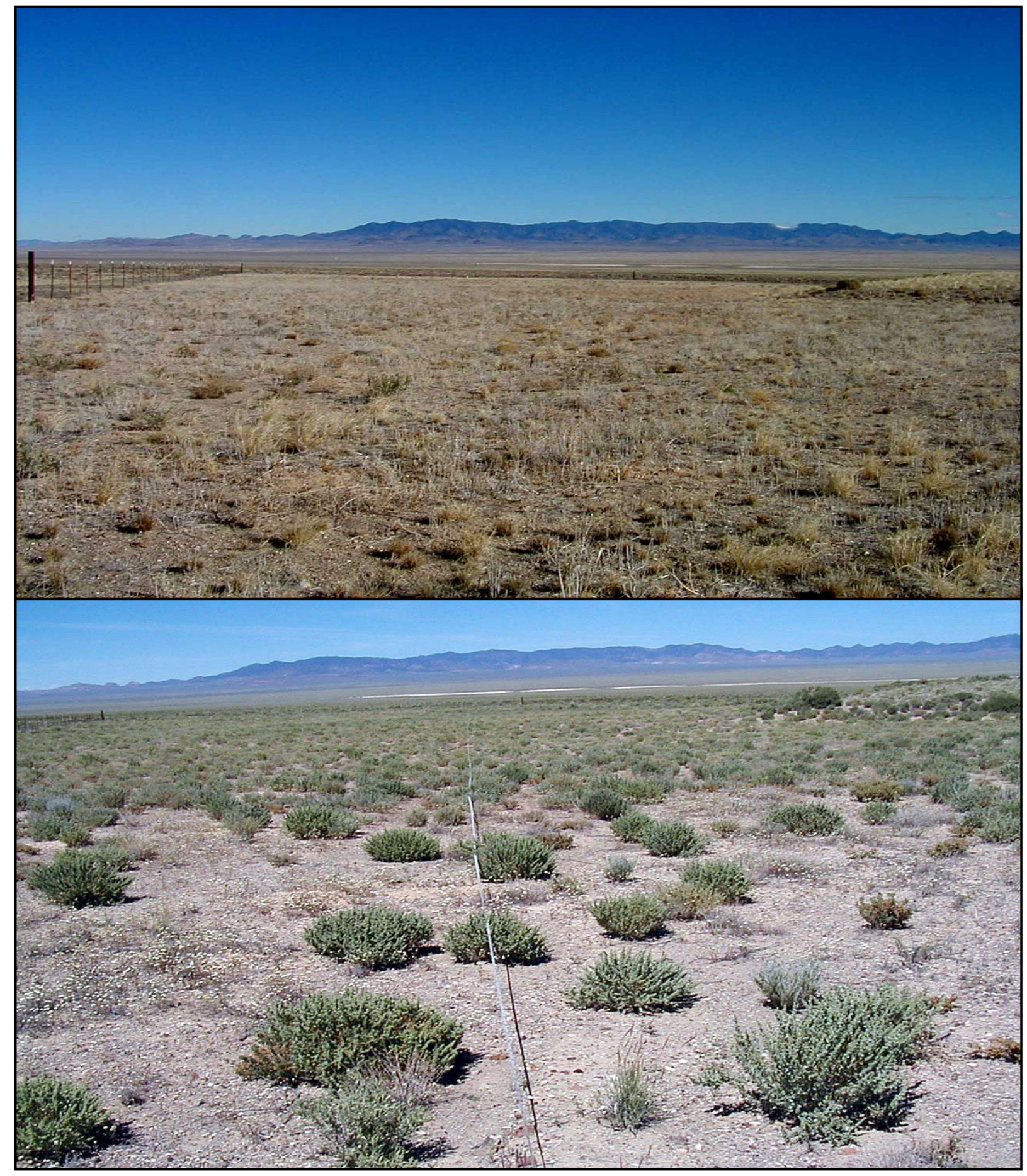

Figure 8-1. Vegetation on staging area at the Rollercoaster Sewage Lagoon closure site in 2000 (top photo) and 2005 (bottom photo). (Photographs by D. C. Anderson, June 2000 and June 2005) 


\subsubsection{Area 6, Water Line}

In 2005, a waterline pipeline was replaced that disturbed approximately 3.8 ha (9.5 ac) of desert tortoise habitat. A site-specific reclamation plan was submitted to the FWS to reseed this area instead of paying into the mitigation fund. The project consisted of two phases which were completed and seeded at different times. The first phase of construction was completed in May and was seeded in early May 2005 with a mixture of seven native species common to the adjacent area. The seeded species included: Larrea tridentata (creosote bush), Ambrosia dumosa (white bursage), Atriplex canescens, A. confertifolia, Ephedra nevadensis (Nevada jointfir), Achnatherum hymenoides, and Sphaeralcea ambigua (desert globemallow). The area was harrowed to prepare a seedbed and was hand seeded. The seed was then buried using a drag harrow. Following the harrowing, a water truck was used to spray on water to settle any dust and provide moisture for seed germination. Water was only applied once following seeding.

Construction was not completed on the second phase until mid summer so seeding was delayed until fall. On September 29, 2005, the area was initially prepared using a drag harrow to relieve compaction in the upper 2.5-5 cm (1-2 in.). The area was then seeded with the same seven species used on the first phase. Following seeding, the area was again harrowed to bury the seed. This was followed by blowing straw on to the site to help conserve soil moisture and protect the soil surface from erosion. The straw was crimped to help hold it in place.

Because of the lack of rainfall following these seedings, germination was poor and no monitoring data were taken at these sites in 2006. If sufficient rainfall occurs in 2007 to cause germination and establishment, these areas will be sampled.

\subsubsection{Vegetative Cover Caps}

Part of the closure cover remediation process involved the placement of an engineered cover cap followed by the establishment of a vegetative cover. The objective of the vegetative cover is to control surface soil erosion and secondarily, and probably more importantly, to minimize the quantity and depth of water infiltration. Shallow rooted native plants capture and remove soil moisture via evapotranspiration. This year cover caps at the CNTA site, two of the TTR closure sites and one at Area 3 on the NTS were monitored. Results are presented in the following sections.

\subsubsection{CAU 417-Central Nevada Test Area: Cover cap}

The cover cap at the CNTA is over 2.9 ha $(7.1 \mathrm{ac})$ in size and is located in a sagebrush shrubland in the Hot Creek valley in central Nevada. Remedial activities were completed in the summer of 2000 and the site was revegetated using a combination of seeding and transplanting that fall. Sampling in 2001 and 2002 was completed in the fall which was past peak-plant production. Since 2002, all monitoring has been completed in the spring (June) during peak-plant production. Only data collected since 2003 are used for analyses.

This year, total plant cover increased by about 2 percent over the last 3 years and only slightly less than the highest cover recorded in 2003 (Table 8-9). Shrub cover declined slightly and perennial grass cover increased from 3.4 to 4.7 percent from 2005 to 2006 which is a 38-percent increase. Grasses have shown a significant increase in cover the last couple years. From 2003 to 2004, shrub cover decreased from 26 to 21 percent, but has increased since 2004 because of above-normal precipitation and improved growing conditions (Figure 8-2). The last 2 years, cover has been about 23 percent. 
Table 8-9. Plant cover on CAU 417-UC-1: Central Mud Pit.

\begin{tabular}{lccccc}
\hline & \multicolumn{5}{c}{ Percent Plant Cover } \\
& $\mathbf{2 0 0 3}$ & $\mathbf{2 0 0 4}$ & $\mathbf{2 0 0 5}$ & $\mathbf{2 0 0 6}$ & Reference \\
\hline Shrub & 26.1 & 21.3 & 22.7 & 23.3 & 31.0 \\
Grass & 2.3 & 1.3 & 3.4 & 4.7 & 3.3 \\
Forbs/Annuals & $\underline{0.0}$ & $\underline{0.6}$ & $\underline{0.4}$ & $\underline{0.0}$ & $\underline{0.0}$ \\
Total Plant Cover & 28.4 & 23.2 & 26.1 & 28.0 & 34.3 \\
& & & & & 40.9 \\
Bare Ground & 30.0 & 46.9 & 47.4 & 31.2 & 19.0 \\
Litter & 42.0 & 30.0 & 26.1 & & \\
\hline
\end{tabular}

The amount of bare ground decreased slightly this year and litter increased from last year (Table 8-9). The amount of litter was high the first few years after revegetation primarily due to the straw mulch used during the reseeding process. The straw mulch has decomposed over the years and the amount of litter covering the surface has shown a decline from 2003 to 2005 . The increase in litter this year may be the result of an increase in native plant growth and litter the last couple of years.

The density of perennial plants on the closure cover decreased to 14.3 plants $/ \mathrm{m}^{2}\left(1.33\right.$ plants $\left./ \mathrm{ft}^{2}\right)$ this year (Table 8-10). The density of grasses was about the same as last year. The overall decline was in the number of shrubs found on the site, specifically a 28-percent decline in the density of $C$. viscidiflorus (Table 8-10). The other major shrub species changed less than 10 percent from last year. Unlike the previous 3 years, no annual forbs were encountered in 2006. 
Table 8-10. Plant density on CAU 417-UC-1: Central Mud Pit.

\begin{tabular}{|c|c|c|c|c|c|}
\hline \multirow[b]{2}{*}{ Species } & \multicolumn{5}{|c|}{ Plants $/ \mathrm{m}^{2}$ with plants $/ \mathrm{ft}^{2}$ in parentheses } \\
\hline & 2003 & 2004 & 2005 & 2006 & Reference \\
\hline \multicolumn{6}{|l|}{ Shrubs } \\
\hline $\begin{array}{l}\text { Artemisia tridentata } \\
\text { (big sagebrush) }\end{array}$ & $\begin{array}{l}6.6 \\
(0.61)\end{array}$ & $\begin{array}{c}4.0 \\
(0.37)\end{array}$ & $\begin{array}{l}2.6 \\
(0.24)\end{array}$ & $\begin{array}{c}2.4 \\
(0.22)\end{array}$ & $\begin{array}{c}2.3 \\
(0.21)\end{array}$ \\
\hline $\begin{array}{l}\text { Atriplex canescens } \\
\text { (fourwing saltbush) }\end{array}$ & $\begin{array}{c}5.3 \\
(0.49)\end{array}$ & $\begin{array}{c}5.5 \\
(0.51)\end{array}$ & $\begin{array}{l}3.0 \\
(0.28)\end{array}$ & $\begin{array}{c}3.3 \\
(0.31)\end{array}$ & $\begin{array}{c}0.0 \\
(0.00)\end{array}$ \\
\hline $\begin{array}{l}\text { Chrysothamnus viscidiflorus } \\
\text { (Douglas rabbitbrush) }\end{array}$ & $\begin{array}{c}5.8 \\
(0.54)\end{array}$ & $\begin{array}{c}4.9 \\
(0.46)\end{array}$ & $\begin{array}{c}4.9 \\
(0.46)\end{array}$ & $\begin{array}{c}3.5 \\
(0.33)\end{array}$ & $\begin{array}{c}0.9 \\
(0.08)\end{array}$ \\
\hline $\begin{array}{l}\text { Ericameria nauseosa } \\
\text { (rubber rabbitbrush) }\end{array}$ & $\begin{array}{c}8.2 \\
(0.76)\end{array}$ & $\begin{array}{c}4.7 \\
(0.44)\end{array}$ & $\begin{array}{c}3.2 \\
(0.30)\end{array}$ & $\begin{array}{c}2.9 \\
(0.27)\end{array}$ & $\begin{array}{c}0.0 \\
(0.00)\end{array}$ \\
\hline \multicolumn{6}{|l|}{ Grasses } \\
\hline $\begin{array}{l}\text { Achnatherum hymenoides } \\
\text { (Indian ricegrass) }\end{array}$ & $\begin{array}{c}3.1 \\
(0.29)\end{array}$ & $\begin{array}{c}2.3 \\
(0.21)\end{array}$ & $\begin{array}{c}1.7 \\
(0.16)\end{array}$ & $\begin{array}{c}1.8 \\
(0.17)\end{array}$ & $\begin{array}{c}0.1 \\
(0.01)\end{array}$ \\
\hline $\begin{array}{l}\text { Elymus elymoides } \\
\text { (squirreltail) }\end{array}$ & $\begin{array}{c}0.7 \\
(0.07)\end{array}$ & $\begin{array}{c}0.4 \\
(0.04)\end{array}$ & $\begin{array}{c}0.5 \\
(0.05)\end{array}$ & $\begin{array}{c}0.4 \\
(0.04)\end{array}$ & $\begin{array}{c}1.5 \\
(0.14)\end{array}$ \\
\hline $\begin{array}{l}\text { Pleuraphis jamesii } \\
\text { (galleta) }\end{array}$ & $\begin{array}{c}0.0 \\
(0.00)\end{array}$ & $\begin{array}{c}0.0 \\
(0.00)\end{array}$ & $\begin{array}{l}0.0 \\
(0.00)\end{array}$ & $\begin{array}{c}0.0 \\
(0.00)\end{array}$ & $\begin{array}{c}2.3 \\
(0.21)\end{array}$ \\
\hline \multicolumn{6}{|l|}{ Summary by Life-form } \\
\hline Shrubs & $\begin{array}{l}25.9 \\
(2.41)\end{array}$ & $\begin{array}{l}19.1 \\
(1.77)\end{array}$ & $\begin{array}{l}13.7 \\
(1.27)\end{array}$ & $\begin{array}{l}12.0 \\
(1.11)\end{array}$ & $\begin{array}{c}3.2 \\
(0.30)\end{array}$ \\
\hline Grasses & $\begin{array}{c}3.8 \\
(0.35)\end{array}$ & $\begin{array}{c}2.7 \\
(0.25)\end{array}$ & $\begin{array}{c}2.1 \\
(0.20)\end{array}$ & $\begin{array}{l}2.3 \\
(0.21)\end{array}$ & $\begin{array}{c}4.0 \\
(0.37)\end{array}$ \\
\hline Forbs/Unseeded & $\begin{array}{r}0.2 \\
(0.02) \\
\end{array}$ & $\begin{array}{c}0.3 \\
(0.03) \\
\end{array}$ & $\begin{array}{c}0.4 \\
(0.04) \\
\end{array}$ & $\begin{array}{c}0.0 \\
(0.00) \\
\end{array}$ & $\begin{array}{r}0.0 \\
(0.00) \\
\end{array}$ \\
\hline Total Plant Density & $\begin{array}{c}29.9 \\
(278.00)\end{array}$ & $\begin{array}{l}22.1 \\
(2.05)\end{array}$ & $\begin{array}{c}16.2 \\
(1.51)\end{array}$ & $\begin{array}{c}14.3 \\
(1.33)\end{array}$ & $\begin{array}{c}7.2 \\
(0.67)\end{array}$ \\
\hline
\end{tabular}




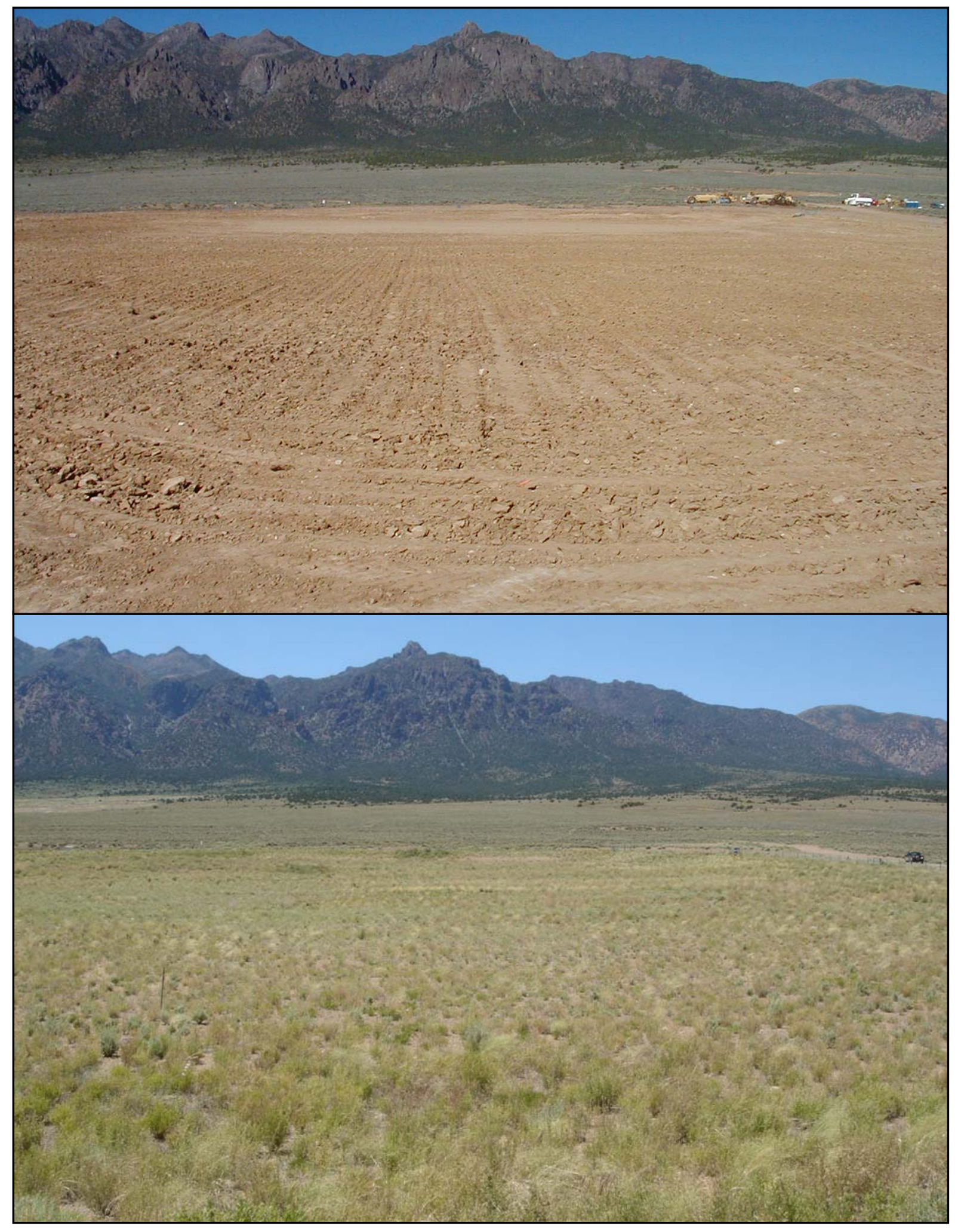

Figure 8-2. CNTA closure cover cap in 2000 following site preparation and seeding (top photograph) and June 2006 (bottom photograph). (Photographs by D. C. Anderson, October 2000 and June 2006) 


\subsubsection{CAU 426-Cactus Springs Waste Trenches: Cover Cap}

The cover cap at the Cactus Springs Waste Trenches is relatively small compared to the ones at CNTA and the Rollercoaster Sewage Lagoons sites. The site is adjacent to Cactus Springs at the base of the Cactus Range Mountains. It was revegetated in the fall of 1997 using a mix of seeds native to the area. The site has been monitored periodically since it was revegetated.

Since 2002, the amount of perennial plant cover on the Cactus Springs Waste Trenches cover cap has been around 15 percent. A low of 10 percent was experienced in 2005, but combined shrub and grass cover was 20 percent this year, the highest cover value recorded for the cover cap at the Cactus Springs Waste Trench site (Table 8-11). The amount of shrub cover is almost 2 percent higher than the previous high of 15 percent in 2003. Grass cover is up from 0 percent last year, but is still only half of what it was in 2004. The only year annual forbs have contributed to overall plant cover was in 2005.

Table 8-11. Plant cover at CAU 426-Cactus Springs Waste Trenches: Cover cap.

\begin{tabular}{lccccccc}
\hline & \multicolumn{7}{c}{ Percent Plant Cover } \\
& $\mathbf{2 0 0 0}$ & $\mathbf{2 0 0 2}$ & $\mathbf{2 0 0 3}$ & $\mathbf{2 0 0 4}$ & $\mathbf{2 0 0 5}$ & $\mathbf{2 0 0 6}$ & Reference \\
\hline Shrub & 0.0 & 6.7 & 15.0 & 10.0 & 10.0 & 16.7 & 10.8 \\
Grass & 3.3 & 8.3 & 1.7 & 6.7 & 0.0 & 3.3 & 0.0 \\
Forbs/Annuals & $\underline{0.0}$ & $\underline{0.0}$ & $\underline{0.0}$ & $\underline{0.0}$ & $\underline{10.0}$ & $\underline{0.0}$ & $\underline{1.7}$ \\
Total Plant Cover & 3.3 & 15.0 & 16.7 & 16.7 & 20.0 & 20.0 & 12.5 \\
& & & & & & & 75.0 \\
Bare Ground & 85.0 & 78.3 & 80.0 & 80.0 & 75.0 & 76.7 & 7.0 \\
Litter & 11.7 & 6.7 & 3.3 & 3.3 & 5.0 & 3.3 & 12.5 \\
\hline
\end{tabular}

There was a decline in the density of all life-forms from 2005 to 2006 . The decline in the shrubs was attributable to declines in the density of $C$. viscidiflorus and E. nauseosus, the two most abundant species on the site, and E. nevadensis (Table 8-12). E. elymoides and A. hymenoides, two common grasses, also declined. There was a slight increase in the number of $P$. jamesii plants. Last year plant densities were at the highest level experienced at this site, while density estimates this year are similar to those prior to 2005.

Shrub cover and density estimates this year were greater on the closure cover than on the adjacent reference area (Tables 8-11 and 8-12). Grasses are uncommon on the reference area, possibly because of the proximity of the site to Cactus Springs, which is frequented by local horse herds. Grasses did not contribute to the overall cover on the reference area this year, although in past years there has been between 1 and 2 percent grass cover. Grass cover on the cover cap has fluctuated from a high of 8 percent in 2002 to a low of 0 percent last year. Typically, grass cover on the cover cap is higher than is recorded on the reference area. Grass density, however, was slightly less than was recorded on the reference area, suggesting that individual plants are more vigorous on the cover cap. Overall, the vegetation on the cover cap at the Cactus Springs Waste Trench site is well established. Shrubs and grasses are vigorous and healthy on the closure cover. Plant density and cover for both life-forms are similar to that experienced on the adjacent reference area. 
Table 8-12. Plant density at CAU 426-Cactus Springs Waste Trenches: Cover cap.

\begin{tabular}{|c|c|c|c|c|c|c|c|}
\hline \multirow[b]{2}{*}{ Species } & \multicolumn{7}{|c|}{ Plants $/ \mathrm{m}^{2}$ with plants $/ \mathrm{ft}^{2}$ in parentheses } \\
\hline & 2000 & 2002 & 2003 & 2004 & 2005 & 2006 & Reference \\
\hline \multicolumn{8}{|l|}{ Shrubs } \\
\hline $\begin{array}{l}\text { Artemisia nova } \\
\text { (black sagebrush) }\end{array}$ & $\begin{array}{c}0.0 \\
(0.00)\end{array}$ & $\begin{array}{c}0.0 \\
(0.00)\end{array}$ & $\begin{array}{c}0.0 \\
(0.00)\end{array}$ & $\begin{array}{c}0.0 \\
(0.00)\end{array}$ & $\begin{array}{c}0.0 \\
(0.00)\end{array}$ & $\begin{array}{c}0.0 \\
(0.00)\end{array}$ & $\begin{array}{c}0.8 \\
(0.07)\end{array}$ \\
\hline $\begin{array}{l}\text { Picrothamnus desertorum } \\
\text { (bud sagebrush) }\end{array}$ & $\begin{array}{c}0.0 \\
(0.00)\end{array}$ & $\begin{array}{c}0.0 \\
(0.00)\end{array}$ & $\begin{array}{c}0.0 \\
(0.00)\end{array}$ & $\begin{array}{c}0.0 \\
(0.00)\end{array}$ & $\begin{array}{c}0.0 \\
(0.00)\end{array}$ & $\begin{array}{c}0.0 \\
(0.00)\end{array}$ & $\begin{array}{c}0.4 \\
(0.04)\end{array}$ \\
\hline $\begin{array}{l}\text { Atriplex canescens } \\
\text { (fourwing saltbush) }\end{array}$ & $\begin{array}{c}0.0 \\
(0.00)\end{array}$ & $\begin{array}{c}0.0 \\
(0.00)\end{array}$ & $\begin{array}{c}0.0 \\
(0.00)\end{array}$ & $\begin{array}{c}0.0 \\
(0.00)\end{array}$ & $\begin{array}{c}0.0 \\
(0.00)\end{array}$ & $\begin{array}{c}0.0 \\
(0.00)\end{array}$ & $\begin{array}{c}0.0 \\
(0.00)\end{array}$ \\
\hline $\begin{array}{l}\text { Atriplex confertifolia } \\
\text { (shadscale) }\end{array}$ & $\begin{array}{c}0.0 \\
(0.00)\end{array}$ & $\begin{array}{c}0.0 \\
(0.00)\end{array}$ & $\begin{array}{c}0.0 \\
(0.00)\end{array}$ & $\begin{array}{c}0.0 \\
(0.00)\end{array}$ & $\begin{array}{c}0.0 \\
(0.00)\end{array}$ & $\begin{array}{c}0.0 \\
(0.00)\end{array}$ & $\begin{array}{c}0.3 \\
(0.03)\end{array}$ \\
\hline $\begin{array}{l}\text { Ephedra nevadensis } \\
\text { (Nevada jointfir) }\end{array}$ & $\begin{array}{c}0.1 \\
(0.01)\end{array}$ & $\begin{array}{c}0.1 \\
(0.01)\end{array}$ & $\begin{array}{c}0.1 \\
(0.01)\end{array}$ & $\begin{array}{c}0.1 \\
(0.01)\end{array}$ & $\begin{array}{c}0.3 \\
(0.3)\end{array}$ & $\begin{array}{c}0.2 \\
(0.02)\end{array}$ & $\begin{array}{c}0.0 \\
(0.00)\end{array}$ \\
\hline $\begin{array}{l}\text { Chrysothamnus viscidiflorus } \\
\text { (Douglas' rabbitbrush) }\end{array}$ & $\begin{array}{c}1.0 \\
(0.09)\end{array}$ & $\begin{array}{c}1.3 \\
(0.12)\end{array}$ & $\begin{array}{c}1.3 \\
(0.12)\end{array}$ & $\begin{array}{c}1.5 \\
(0.14)\end{array}$ & $\begin{array}{c}1.3 \\
(0.12)\end{array}$ & $\begin{array}{c}1.0 \\
(0.09)\end{array}$ & $\begin{array}{c}0.0 \\
(0.00)\end{array}$ \\
\hline $\begin{array}{l}\text { Ericameria nauseosa } \\
\text { (rubber rabbitbrush) }\end{array}$ & $\begin{array}{c}0.1 \\
(0.01)\end{array}$ & $\begin{array}{c}1.1 \\
(0.11)\end{array}$ & $\begin{array}{c}0.5 \\
(0.05)\end{array}$ & $\begin{array}{c}0.9 \\
(0.08)\end{array}$ & $\begin{array}{c}1.5 \\
(0.14)\end{array}$ & $\begin{array}{c}0.8 \\
(0.07)\end{array}$ & $\begin{array}{c}0.0 \\
(0.00)\end{array}$ \\
\hline $\begin{array}{l}\text { Krascheninnikovia lanata } \\
\text { (winterfat) }\end{array}$ & $\begin{array}{c}0.1 \\
(0.01)\end{array}$ & $\begin{array}{c}0.0 \\
(0.00)\end{array}$ & $\begin{array}{c}0.0 \\
(0.00)\end{array}$ & $\begin{array}{c}0.0 \\
(0.00)\end{array}$ & $\begin{array}{c}0.0 \\
(0.00)\end{array}$ & $\begin{array}{c}0.0 \\
(0.00)\end{array}$ & $\begin{array}{c}0.0 \\
(0.00)\end{array}$ \\
\hline \multicolumn{8}{|l|}{ Grasses } \\
\hline $\begin{array}{l}\text { Achnatherum hymenoides } \\
\text { (Indian ricegrass) }\end{array}$ & $\begin{array}{c}1.3 \\
(0.12)\end{array}$ & $\begin{array}{c}0.7 \\
(0.07)\end{array}$ & $\begin{array}{c}0.6 \\
(0.06)\end{array}$ & $\begin{array}{c}0.7 \\
(0.06)\end{array}$ & $\begin{array}{c}2.0 \\
(0.19)\end{array}$ & $\begin{array}{c}1.4 \\
(0.13)\end{array}$ & $\begin{array}{c}0.1 \\
(0.01)\end{array}$ \\
\hline $\begin{array}{l}\text { Elymus elymoides } \\
\text { (squirreltail) }\end{array}$ & $\begin{array}{c}1.0 \\
(0.09)\end{array}$ & $\begin{array}{c}0.2 \\
(0.02)\end{array}$ & $\begin{array}{c}0.3 \\
(0.03)\end{array}$ & $\begin{array}{c}0.3 \\
(0.03)\end{array}$ & $\begin{array}{c}1.0 \\
(0.09)\end{array}$ & $\begin{array}{c}0.7 \\
(0.07)\end{array}$ & $\begin{array}{c}0.1 \\
(0.01)\end{array}$ \\
\hline $\begin{array}{l}\text { Pleuraphis jamesii } \\
\text { (galleta) }\end{array}$ & $\begin{array}{c}1.4 \\
(0.13)\end{array}$ & $\begin{array}{c}0.7 \\
(0.06)\end{array}$ & $\begin{array}{c}0.4 \\
(0.04)\end{array}$ & $\begin{array}{c}0.0 \\
(0.00)\end{array}$ & $\begin{array}{c}0.3 \\
(0.03)\end{array}$ & $\begin{array}{c}0.4 \\
(0.04)\end{array}$ & $\begin{array}{l}3.0 \\
(0.03)\end{array}$ \\
\hline \multicolumn{8}{|l|}{ Summary by Life-form } \\
\hline Shrubs & $\begin{array}{c}1.3 \\
(0.12)\end{array}$ & $\begin{array}{c}2.5 \\
(0.24)\end{array}$ & $\begin{array}{c}1.9 \\
(0.18)\end{array}$ & $\begin{array}{c}2.4 \\
(0.22)\end{array}$ & $\begin{array}{c}3.1 \\
(0.28)\end{array}$ & $\begin{array}{c}2.0 \\
(0.19)\end{array}$ & $\begin{array}{c}1.5 \\
(0.13)\end{array}$ \\
\hline Grasses & $\begin{array}{c}3.7 \\
(0.37)\end{array}$ & $\begin{array}{c}1.6 \\
(0.15)\end{array}$ & $\begin{array}{c}1.3 \\
(0.12)\end{array}$ & $\begin{array}{c}1.0 \\
(0.09)\end{array}$ & $\begin{array}{c}3.3 \\
(0.30)\end{array}$ & $\begin{array}{c}2.5 \\
(0.23)\end{array}$ & $\begin{array}{c}3.8 \\
(0.35)\end{array}$ \\
\hline Forbs/Annuals & $\begin{array}{c}0.1 \\
(0.01) \\
\end{array}$ & $\begin{array}{c}1.1 \\
(0.11) \\
\end{array}$ & $\begin{array}{c}0.3 \\
(0.03) \\
\end{array}$ & $\begin{array}{c}0.0 \\
(0.00) \\
\end{array}$ & $\begin{array}{c}2.9 \\
(0.27) \\
\end{array}$ & $\begin{array}{c}0.6 \\
(0.06) \\
\end{array}$ & $\begin{array}{c}1.6 \\
(0.14) \\
\end{array}$ \\
\hline Total Plant Density & $\begin{array}{c}5.0 \\
(0.46)\end{array}$ & $\begin{array}{c}5.3 \\
(0.49)\end{array}$ & $\begin{array}{c}3.5 \\
(0.32)\end{array}$ & $\begin{array}{c}3.4 \\
(0.32)\end{array}$ & $\begin{array}{c}9.2 \\
(0.85)\end{array}$ & $\begin{array}{c}5.1 \\
(0.47)\end{array}$ & $\begin{array}{c}6.8 \\
(0.63)\end{array}$ \\
\hline
\end{tabular}

\subsubsection{CAU 404-Rollercoaster Sewage Lagoons: Cover Cap}

The Rollercoaster Sewage Lagoon site covers approximately 2.2 ha (5.5 ac) midslope between the Cactus Mountain Range and Cactus Flats on the TTR. About one quarter of the site is a cover cap which is $1 \mathrm{~m}$ (3.2 ft) higher than the rest of the site. The cover cap was seeded with a mix of native shrubs and grasses in the fall of 1997. Plant cover and density as well as overall condition of the cover cap have been monitored since the spring of 1998. 
Plant cover on the cover cap decreased from an all-time high of 36.3 percent in 2005 to 25.6 percent in 2006 (Table 8-13). Shrub cover and annual forb cover both decreased from 2005 levels; however, grass cover increased. Grass cover was higher this year than it has been since 2002. Although shrub cover decreased to 13.4 percent, it still represents the second highest amount of shrub cover since the site was revegetated. Grass cover has increased each year the last three years from an all time low of 3.8 percent in 2004. Forbs have only contributed to overall cover two of the six years when sampling was conducted. The composition of plant cover is an equal percentage of grass cover as shrub cover. At most sites, shrubs are the most dominant and grasses contribute less to overall plant cover.

Table 8-13. Percent plant cover at CAU 404-Rollercoaster Sewage Lagoons: Cover cap.

\begin{tabular}{lccccccc}
\hline & \multicolumn{7}{c}{ Percent Plant Cover } \\
& $\mathbf{2 0 0 0}$ & $\mathbf{2 0 0 2}$ & $\mathbf{2 0 0 3}$ & $\mathbf{2 0 0 4}$ & $\mathbf{2 0 0 5}$ & $\mathbf{2 0 0 6}$ & Reference \\
\hline Shrub & 6.3 & 10.0 & 12.5 & 10.0 & 18.8 & 13.4 & 11.1 \\
Grass & 12.5 & 16.3 & 10.0 & 3.8 & 10.0 & 12.2 & 2.8 \\
Forbs/Annuals & $\underline{0.0}$ & $\underline{0.0}$ & $\underline{0.0}$ & $\underline{1.3}$ & $\underline{7.5}$ & $\underline{0.0}$ & $\underline{3.3}$ \\
$\quad$ Total Plant Cover & 18.8 & 26.3 & 22.5 & 15.0 & 36.3 & 25.6 & 17.2 \\
& & & & & & & \\
Bare Ground & 73.8 & 65.0 & 71.3 & 77.5 & 57.5 & 65.9 & 55.0 \\
Litter & 7.5 & 8.8 & 6.3 & 7.5 & 6.3 & 8.4 & 27.8 \\
\hline
\end{tabular}

Plant density was lower this year than it has ever been on the cover cap (Table 8-14). However, there are still about six individual shrubs and five individual grasses found within $1 \mathrm{~m}^{2}\left(0.09 \mathrm{ft}^{2}\right)$. A. confertifolia continues to be the most dominant species. P. desertorum and A. canescens are present, but at lower densities. P. jamesii is the most common grass. The only other grass encountered was A. hymenoides, which declined slightly this year in comparison to 2004. Last year, there were a few plants of E. elymoides found, but there were none encountered this year.

There has been a gradual decline in the density of shrubs and grasses since the site was revegetated. There was a decrease in shrub density last year from 2005 with $6.3 \mathrm{shrubs} / \mathrm{m}^{2}\left(0.59 \mathrm{shrubs} / \mathrm{ft}^{2}\right)$ this year which is the lowest density recorded to date. A similar decline occurs for the grasses. The decrease from 2005 to 2006 appears to be a result of a decrease in the density of A. canescens, A. confertifolia, and $P$. jamesii.

Both shrub and grass cover exceed that found on the reference site (Table 8-13). Shrub cover is 120 percent of the shrub cover on the reference area and grass cover is almost four times the amount found on the reference site. Shrub and grass densities, although the lowest reported to data, are still well above the density reported for the reference area (i.e., 3.4 and 1.4, respectively) (Table 8-14). Shrubs are about twice as abundant on the cover cap as on the reference area and grass densities are more than three times what they are on the reference area. 
Table 8-14. Plant density at CAU 404-Rollercoaster Sewage Lagoons: Cover cap.

\begin{tabular}{|c|c|c|c|c|c|c|c|}
\hline \multirow[b]{2}{*}{ Species } & \multicolumn{7}{|c|}{ Plants $/ \mathrm{m}^{2}$ with plants $/ \mathrm{ft}^{2}$ in parentheses } \\
\hline & 2000 & 2002 & 2003 & 2004 & 2005 & 2006 & Reference \\
\hline \multicolumn{8}{|l|}{ Shrubs } \\
\hline $\begin{array}{l}\text { Picrothamnus desertorum } \\
\text { (bud sagebrush) }\end{array}$ & $\begin{array}{c}2.1 \\
(0.19)\end{array}$ & $\begin{array}{c}1.7 \\
(0.15)\end{array}$ & $\begin{array}{c}1.2 \\
(0.11)\end{array}$ & $\begin{array}{c}1.0 \\
(0.09)\end{array}$ & $\begin{array}{c}0.9 \\
(0.08)\end{array}$ & $\begin{array}{c}0.8 \\
(0.08)\end{array}$ & $\begin{array}{c}2.6 \\
(0.24)\end{array}$ \\
\hline $\begin{array}{l}\text { Atriplex canescens } \\
\text { (fourwing saltbush) }\end{array}$ & $\begin{array}{c}0.9 \\
(0.08)\end{array}$ & $\begin{array}{c}0.6 \\
(0.06)\end{array}$ & $\begin{array}{c}0.3 \\
(0.03)\end{array}$ & $\begin{array}{c}0.5 \\
(0.04)\end{array}$ & $\begin{array}{c}0.6 \\
(0.06)\end{array}$ & $\begin{array}{c}0.3 \\
(0.03)\end{array}$ & $\begin{array}{c}0.0 \\
(0.00)\end{array}$ \\
\hline $\begin{array}{l}\text { Atriplex confertifolia } \\
\text { (shadscale) }\end{array}$ & $\begin{array}{c}10.9 \\
(1.01)\end{array}$ & $\begin{array}{c}7.0 \\
(0.65)\end{array}$ & $\begin{array}{c}7.0 \\
(0.65)\end{array}$ & $\begin{array}{c}5.9 \\
(0.54)\end{array}$ & $\begin{array}{c}6.6 \\
(0.61)\end{array}$ & $\begin{array}{c}5.1 \\
(0.47)\end{array}$ & $\begin{array}{c}0.8 \\
(0.07)\end{array}$ \\
\hline $\begin{array}{l}\text { Krascheninnikovia lanata } \\
\text { (winterfat) }\end{array}$ & $\begin{array}{c}0.3 \\
(0.03)\end{array}$ & $\begin{array}{c}0.1 \\
(0.01)\end{array}$ & $\begin{array}{c}0.0 \\
(0.00)\end{array}$ & $\begin{array}{c}0.0 \\
(0.00)\end{array}$ & $\begin{array}{c}0.0 \\
(0.00)\end{array}$ & $\begin{array}{c}0.1 \\
(0.01)\end{array}$ & $\begin{array}{c}0.1 \\
(0.01)\end{array}$ \\
\hline \multicolumn{8}{|l|}{ Grasses } \\
\hline $\begin{array}{l}\text { Achnatherum hymenoides } \\
\text { (Indian ricegrass) }\end{array}$ & $\begin{array}{c}3.8 \\
(0.35)\end{array}$ & $\begin{array}{c}2.8 \\
(0.26)\end{array}$ & $\begin{array}{c}1.1 \\
(0.10)\end{array}$ & $\begin{array}{c}0.6 \\
(0.06)\end{array}$ & $\begin{array}{c}0.2 \\
(0.02)\end{array}$ & $\begin{array}{c}0.3 \\
(0.03)\end{array}$ & $\begin{array}{c}0.3 \\
(0.03)\end{array}$ \\
\hline $\begin{array}{l}\text { Elymus elymoides } \\
\text { (squirreltail) }\end{array}$ & $\begin{array}{l}10.8 \\
(1.00)\end{array}$ & $\begin{array}{c}1.6 \\
(0.14)\end{array}$ & $\begin{array}{c}0.1 \\
(0.01)\end{array}$ & $\begin{array}{c}0.0 \\
(0.00)\end{array}$ & $\begin{array}{c}0.1 \\
(0.01)\end{array}$ & $\begin{array}{c}0.0 \\
(0.00)\end{array}$ & $\begin{array}{c}0.0 \\
(0.00)\end{array}$ \\
\hline $\begin{array}{l}\text { Dasyochloa pulchella } \\
\text { (low woolygrass) }\end{array}$ & $\begin{array}{c}0.0 \\
(0.00)\end{array}$ & $\begin{array}{c}0.0 \\
(0.00)\end{array}$ & $\begin{array}{c}0.0 \\
(0.00)\end{array}$ & $\begin{array}{c}0.0 \\
(0.00)\end{array}$ & $\begin{array}{c}0.0 \\
(0.00)\end{array}$ & $\begin{array}{c}0.0 \\
(0.00)\end{array}$ & $\begin{array}{c}0.3 \\
(0.03)\end{array}$ \\
\hline $\begin{array}{l}\text { Pleuraphis jamesii } \\
\text { (galleta) }\end{array}$ & $\begin{array}{l}8.6 \\
(0.80)\end{array}$ & $\begin{array}{c}4.7 \\
(0.43)\end{array}$ & $\begin{array}{c}4.9 \\
(0.45)\end{array}$ & $\begin{array}{l}5.2 \\
(0.48)\end{array}$ & $\begin{array}{l}5.1 \\
(0.47)\end{array}$ & $\begin{array}{c}4.4 \\
(0.41)\end{array}$ & $\begin{array}{c}0.8 \\
(0.08)\end{array}$ \\
\hline \multicolumn{8}{|l|}{ Summary by Life-form } \\
\hline Shrubs & $\begin{array}{c}14.2 \\
(1.31)\end{array}$ & $\begin{array}{c}9.3 \\
(0.86)\end{array}$ & $\begin{array}{c}8.4 \\
(0.78)\end{array}$ & $\begin{array}{c}7.3 \\
(0.67)\end{array}$ & $\begin{array}{c}8.1 \\
(0.75)\end{array}$ & $\begin{array}{c}6.3 \\
(0.59)\end{array}$ & $\begin{array}{c}3.4 \\
(0.32)\end{array}$ \\
\hline Grasses & $\begin{array}{c}23.2 \\
(2.15)\end{array}$ & $\begin{array}{c}9.0 \\
(0.84)\end{array}$ & $\begin{array}{c}6.0 \\
(0.55)\end{array}$ & $\begin{array}{c}5.8 \\
(0.54)\end{array}$ & $\begin{array}{c}5.4 \\
(0.40)\end{array}$ & $\begin{array}{c}4.8 \\
(0.44)\end{array}$ & $\begin{array}{c}1.4 \\
(0.13)\end{array}$ \\
\hline Forbs/Annuals & $\begin{aligned} 0.5 \\
(0.04) \\
\end{aligned}$ & $\begin{array}{r}0.3 \\
(0.03) \\
\end{array}$ & $\begin{array}{c}0.2 \\
(0.02) \\
\end{array}$ & $\begin{array}{c}1.9 \\
(0.17) \\
\end{array}$ & $\begin{array}{r}31.5 \\
(2.93) \\
\end{array}$ & $\begin{array}{c}0.5 \\
(0.04) \\
\end{array}$ & $\begin{array}{r}3.3 \\
(0.30) \\
\end{array}$ \\
\hline Total Plant Density & $\begin{array}{c}37.8 \\
(3.51)\end{array}$ & $\begin{array}{c}18.6 \\
(1.73)\end{array}$ & $\begin{array}{c}14.5 \\
(1.35)\end{array}$ & $\begin{array}{c}14.9 \\
(1.38)\end{array}$ & $\begin{array}{c}45.0 \\
(4.18)\end{array}$ & $\begin{array}{l}11.5 \\
(1.07)\end{array}$ & $\begin{array}{c}8.1 \\
(0.76)\end{array}$ \\
\hline
\end{tabular}

\subsubsection{CAU 110-Area U-3ax/bl: Closure Cap}

A closure cap for the U-3ax/bl disposal unit in Area 3 of the NTS was constructed in the fall of 2000.

Immediately after the construction of the closure cap, actions were taken to reestablish a cover of native vegetation. The surface of the completed closure cap was ripped to about $15 \mathrm{~cm}(6 \mathrm{in}$. $)$ and disked to provide a suitable seedbed. A mix of seeds of nine native shrub species, two native grasses, and one native forb was used to seed the surface soils. Revegetation was completed by the end of December 2000. The success of the revegetation effort has been monitored annually since the spring of 2001.

Perennial plant cover increased to 19.6 percent in 2006, the highest it has been since the site was revegetated in 2000 (Table 8-15). Shrubs have shown annual increases in cover since cover was first recorded in 2003. Grasses are still not a major component of the vegetative cover as noted in the absence of any grass cover (Table 8-15). Also of interest is the 0-percent cover for annual plant species. This year and in 2002 are the only years that annual plants have not contributed to total plant cover. There was no living cover this year on the unseeded portion between the fence and the closure cap. Last year, there was 23-percent cover on this 
area, which was all from annual plants, primarily Salsola tragus (prickly Russian thistle) and H. glomeratus, two noxious weeds. No native plant species have established in this area. The importance of reseeding the closure cap was reinforced again this year. Without reseeding, the closure cap would only have a vegetative cover during years of abundant precipitation and the period of active evapotranspiration would be limited to the short (i.e., weeks) life span of annual plants.

Table 8-15. Plant cover at CAU 110 U-3ax/bl: Closure cap.

\begin{tabular}{lccccccc}
\hline & \multicolumn{8}{c}{ Percent Plant Cover } \\
& $\mathbf{2 0 0 1}$ & $\mathbf{2 0 0 2}$ & $\mathbf{2 0 0 3}$ & $\mathbf{2 0 0 4}$ & $\mathbf{2 0 0 5}$ & $\mathbf{2 0 0 6}$ & Unseeded \\
\hline Shrub & 2.6 & 6.4 & 2.4 & 9.6 & 16.8 & 19.6 & 0.0 \\
Grass & 0.0 & 0.0 & 0.0 & 0.0 & 0.0 & 0.0 & 0.0 \\
Forbs/Annuals & $\underline{5.2}$ & $\underline{0.0}$ & $\underline{0.8}$ & $\underline{3.2}$ & $\underline{3.4}$ & $\underline{0.0}$ & $\underline{0.0}$ \\
Total Plant Cover & 7.8 & 6.4 & 3.2 & 12.8 & 20.2 & 19.6 & 0.0 \\
& & & & & & & \\
Bare Ground/Rock & 48.6 & 69.5 & 68.8 & 72.6 & 53.6 & 57.2 & 58.7 \\
Litter/Mulch & 43.6 & 24.1 & 28.0 & 14.6 & 26.2 & 23.2 & 41.3 \\
\hline
\end{tabular}

To assess the revegetation success of a site, comparisons are typically made with adjacent undisturbed habitat. However, there are no sites within close proximity of the U-3ax/bl closure cap that have not been disturbed. In the fall of 1962, permanent vegetation plots were established on the NTS to document longterm ecological changes (Webb et al., 2003) and could serve as a reference for the U-3ax/bl closure cap revegetation effort. The first sampling of these ecological plots occurred in 1963, again in 1975, and finally in 2002. One of the permanent plots is located near the U-3ax/bl closure cap in a A. confertifolia/K. lanata plant assemblage (Webb et al., 2003), which is similar to the type of vegetation that has established on the closure cap. This ecological monitoring plot was visited in 2002 to be sampled, but was found to be heavily disturbed and was not sampled. Data collected in 1963 showed a total vegetative cover of 18.1 percent and in 1975 it was 25.8 percent. The amount of plant cover on the U-3ax/bl closure cap is 19.6 percent (Table 8-15), which is higher than the plant cover in 1963 and slightly lower than that estimated in 1975. The fluctuations in plant cover could have been the direct result of the amount of precipitation received during the growing season, which was $7.9 \mathrm{~cm}$ (3.1 in.) in 1963, well below the normal of $13.2 \mathrm{~cm}(5.2 \mathrm{in}$.). During the 1975 growing season $29.2 \mathrm{~cm}$ (11.5 in.) of precipitation was received, which is almost twice the average and more than was received in 2005 , which may explain the difference in plant cover values.

Another difference between the vegetation on the closure cap and that recorded on the ecological monitoring plot is species composition. P. desertorum, Grayia spinosa (spiny hopsage), and Lycium andersonii (Anderson wolfberry) are common in the native plant community, but they have not established on the closure cap. These species were included in the mix of seeds used to revegetate the site, knowing that they are typically very difficult to establish from seed. A few individual plants of $P$. desertorum and $G$. spinos $a$ are present on the site, but neither species is present in sufficient numbers to make a significant contribution to total plant cover. 
Table 8-16. Plant density at CAU 110 U-3ax/bl: Closure cover cap.

\begin{tabular}{|c|c|c|c|c|c|c|c|}
\hline \multirow[b]{2}{*}{ Species } & \multicolumn{7}{|c|}{ Plants $/ \mathrm{m}^{2}$ with plants $/ \mathrm{ft}^{2}$ in parentheses } \\
\hline & 2001 & 2002 & 2003 & 2004 & 2005 & 2006 & Unseeded \\
\hline \multicolumn{8}{|l|}{ Shrubs } \\
\hline $\begin{array}{c}\text { Ambrosia dumosa } \\
\text { (white bursage) }\end{array}$ & $\begin{array}{c}9.3 \\
(0.86)\end{array}$ & $\begin{array}{c}0.0 \\
(0.00)\end{array}$ & $\begin{array}{c}0.0 \\
(0.00)\end{array}$ & $\begin{array}{c}0.0 \\
(0.00)\end{array}$ & $\begin{array}{c}0.0 \\
(0.00)\end{array}$ & $\begin{array}{c}0.0 \\
(0.00)\end{array}$ & $\begin{array}{c}0.0 \\
(0.00)\end{array}$ \\
\hline $\begin{array}{l}\text { Atriplex canescens } \\
\text { (fourwing saltbush) }\end{array}$ & $\begin{array}{c}0.2 \\
(0.02)\end{array}$ & $\begin{array}{c}0.1 \\
(0.01)\end{array}$ & $\begin{array}{c}0.0 \\
(0.00)\end{array}$ & $\begin{array}{c}0.0 \\
(0.00)\end{array}$ & $\begin{array}{c}0.0 \\
(0.00)\end{array}$ & $\begin{array}{c}0.0 \\
(0.00)\end{array}$ & $\begin{array}{c}0.0 \\
(0.00)\end{array}$ \\
\hline $\begin{array}{l}\text { Atriplex confertifolia } \\
\text { (shadscale) }\end{array}$ & $\begin{array}{l}13.4 \\
(1.24)\end{array}$ & $\begin{array}{l}10.3 \\
(0.96)\end{array}$ & $\begin{array}{c}2.7 \\
(0.25)\end{array}$ & $\begin{array}{c}2.3 \\
(0.21)\end{array}$ & $\begin{array}{c}2.5 \\
(0.23)\end{array}$ & $\begin{array}{c}1.9 \\
(0.18)\end{array}$ & $\begin{array}{c}0.0 \\
(0.00)\end{array}$ \\
\hline $\begin{array}{l}\text { Ephedra nevadensis } \\
\text { (Nevada jointfir) }\end{array}$ & $\begin{array}{c}6.8 \\
(0.63)\end{array}$ & $\begin{array}{c}6.7 \\
(0.62)\end{array}$ & $\begin{array}{c}1.3 \\
(0.12)\end{array}$ & $\begin{array}{c}1.5 \\
(0.14)\end{array}$ & $\begin{array}{c}1.8 \\
(0.17)\end{array}$ & $\begin{array}{c}1.3 \\
(0.12)\end{array}$ & $\begin{array}{c}0.0 \\
(0.00)\end{array}$ \\
\hline $\begin{array}{l}\text { Ericameria nauseosa } \\
\text { (rubber rabbitbrush) }\end{array}$ & $\begin{array}{l}11.2 \\
(1.04)\end{array}$ & $\begin{array}{c}0.7 \\
(0.07)\end{array}$ & $\begin{array}{c}0.0 \\
(0.00)\end{array}$ & $\begin{array}{c}0.0 \\
(0.00)\end{array}$ & $\begin{array}{c}0.0 \\
(0.00)\end{array}$ & $\begin{array}{c}0.0 \\
(0.00)\end{array}$ & $\begin{array}{c}0.0 \\
(0.00)\end{array}$ \\
\hline $\begin{array}{l}\text { Eriogonum fasciculatum } \\
\text { (buckwheat) }\end{array}$ & $\begin{array}{l}11.3 \\
(1.05)\end{array}$ & $\begin{array}{c}4.2 \\
(0.39)\end{array}$ & $\begin{array}{c}0.0 \\
(0.00)\end{array}$ & $\begin{array}{c}0.0 \\
(0.00)\end{array}$ & $\begin{array}{c}0.0 \\
(0.00)\end{array}$ & $\begin{array}{l}0.0 \\
(0.00)\end{array}$ & $\begin{array}{c}0.0 \\
(0.00)\end{array}$ \\
\hline $\begin{array}{l}\text { Grayia spinosa } \\
\text { (spiny hopsage) }\end{array}$ & $\begin{array}{c}1.9 \\
(0.18)\end{array}$ & $\begin{array}{c}0.1 \\
(0.01)\end{array}$ & $\begin{array}{c}0.1 \\
(0.01)\end{array}$ & $\begin{array}{c}0.0 \\
(0.00)\end{array}$ & $\begin{array}{c}0.0 \\
(0.00)\end{array}$ & $\begin{array}{c}0.0 \\
(0.00)\end{array}$ & $\begin{array}{c}0.0 \\
(0.00)\end{array}$ \\
\hline $\begin{array}{l}\text { Kraschenniikovia lanata } \\
\text { (winterfat) }\end{array}$ & $\begin{array}{c}0.3 \\
(0.03)\end{array}$ & $\begin{array}{l}2.7 \\
(0.25)\end{array}$ & $\begin{array}{c}0.4 \\
(0.04)\end{array}$ & $\begin{array}{c}0.7 \\
(0.07)\end{array}$ & $\begin{array}{c}0.4 \\
(0.04)\end{array}$ & $\begin{array}{c}0.3 \\
(0.03)\end{array}$ & $\begin{array}{c}0.0 \\
(0.00)\end{array}$ \\
\hline $\begin{array}{l}\text { Picrothamnus desertorum } \\
\text { (bud sagebrush) }\end{array}$ & $\begin{array}{c}1.9 \\
(0.18)\end{array}$ & $\begin{array}{c}0.0 \\
(0.00)\end{array}$ & $\begin{array}{c}0.0 \\
(0.00)\end{array}$ & $\begin{array}{c}0.0 \\
(0.00)\end{array}$ & $\begin{array}{l}0.0 \\
(0.00)\end{array}$ & $\begin{array}{l}0.0 \\
(0.00)\end{array}$ & $\begin{array}{c}0.0 \\
(0.00)\end{array}$ \\
\hline \multicolumn{8}{|l|}{ Grasses } \\
\hline $\begin{array}{l}\text { Achnatherum hymenoides } \\
\text { (Indian ricegrass) }\end{array}$ & $\begin{array}{c}5.8 \\
(0.54)\end{array}$ & $\begin{array}{c}1.3 \\
(0.12)\end{array}$ & $\begin{array}{c}0.3 \\
(0.03)\end{array}$ & $\begin{array}{c}0.4 \\
(0.04)\end{array}$ & $\begin{array}{c}0.3 \\
(0.03)\end{array}$ & $\begin{array}{c}0.1 \\
(0.01)\end{array}$ & $\begin{array}{c}0.0 \\
(0.00)\end{array}$ \\
\hline $\begin{array}{l}\text { Elymus elymoides } \\
\text { (squirreltail) }\end{array}$ & $\begin{array}{l}3.3 \\
(0.31)\end{array}$ & $\begin{array}{c}0.2 \\
(0.02)\end{array}$ & $\begin{array}{l}0.0 \\
(0.00)\end{array}$ & $\begin{array}{c}0.0 \\
(0.00)\end{array}$ & $\begin{array}{c}0.1 \\
(0.01)\end{array}$ & $\begin{array}{c}0.0 \\
(0.00)\end{array}$ & $\begin{array}{c}0.0 \\
(0.00)\end{array}$ \\
\hline Annual grasses & $\begin{array}{c}0.0 \\
(0.00)\end{array}$ & $\begin{array}{c}0.0 \\
(0.00)\end{array}$ & $\begin{array}{c}0.1 \\
(0.01)\end{array}$ & $\begin{array}{c}0.5 \\
(0.05)\end{array}$ & $\begin{array}{c}1.9 \\
(0.18)\end{array}$ & $\begin{array}{l}1.2 \\
(0.11)\end{array}$ & $\begin{array}{c}0.0 \\
(0.00)\end{array}$ \\
\hline \multicolumn{8}{|l|}{ Summary by Life-form } \\
\hline Shrubs & $\begin{array}{c}56.3 \\
(5.23)\end{array}$ & $\begin{array}{l}24.8 \\
(2.30)\end{array}$ & $\begin{array}{c}4.5 \\
(0.42)\end{array}$ & $\begin{array}{c}4.5 \\
(0.42)\end{array}$ & $\begin{array}{c}4.7 \\
(0.44)\end{array}$ & $\begin{array}{c}3.5 \\
(0.33)\end{array}$ & $\begin{array}{c}0.0 \\
(0.00)\end{array}$ \\
\hline Grasses & $\begin{array}{c}9.1 \\
(0.85)\end{array}$ & $\begin{array}{c}1.5 \\
(0.14)\end{array}$ & $\begin{array}{c}0.4 \\
(0.04)\end{array}$ & $\begin{array}{c}0.9 \\
(0.08)\end{array}$ & $\begin{array}{c}2.3 \\
(0.21)\end{array}$ & $\begin{array}{c}0.1 \\
(0.01)\end{array}$ & $\begin{array}{c}0.0 \\
(0.00)\end{array}$ \\
\hline Annual Forbs/Grasses & $\begin{array}{c}0.0 \\
(0.00) \\
\end{array}$ & $\begin{array}{c}0.0 \\
(0.00) \\
\end{array}$ & $\begin{array}{r}19.5 \\
(1.81) \\
\end{array}$ & $\begin{array}{c}89.1 \\
(8.28) \\
\end{array}$ & $\begin{array}{r}98.5 \\
(9.15) \\
\end{array}$ & $\begin{array}{c}4.7 \\
(0.33) \\
\end{array}$ & $\begin{array}{c}3.5 \\
(0.33) \\
\end{array}$ \\
\hline Total Plant Density & $\begin{array}{c}65.4 \\
(6.08)\end{array}$ & $\begin{array}{c}26.3 \\
(2.44)\end{array}$ & $\begin{array}{c}24.4 \\
(2.27)\end{array}$ & $\begin{array}{c}94.5 \\
(8.78)\end{array}$ & $\begin{array}{l}105.5 \\
(9.80)\end{array}$ & $\begin{array}{c}8.3 \\
(0.77)\end{array}$ & $\begin{array}{c}3.5 \\
(0.33)\end{array}$ \\
\hline
\end{tabular}

The other difference between the U-3ax/bl closure cover and the ecological monitoring plot is in the amount of perennial grasses. Grasses have not contributed to plant cover on the closure cover to date. On the ecological monitoring plot, grasses made up less than 1 percent in 1963 but increased to 2.5 percent in 1973. Grasses contribute a small amount to overall plant cover in this vegetation type; however, it should be more than is currently measured on the closure cover. A. hymenoides and E. elymoides are present on the closure cover and, with time, may contribute more to total plant cover. 
The 3.6 perennial plant species $/ \mathrm{m}^{2}\left(0.34 \mathrm{ft}^{2}\right)$ represents the lowest density measured on the closure cover (Table 8-16). The decrease cannot be attributed to a single species but rather a slight decline in all species including A. confertifolia, E. nevadensis, K. lanata, and A. hymenoides (Table 8-16). P. desertorum and $G$ spinosa were not encountered on the study plots this year. It has been present on site since 2001, but was not encountered in the sampling transects. G. spinosa was observed on the closure cover, but it is uncommon. The other species of note is E. elymoides. It was first observed on the closure cover in 2002 and a few individuals, mainly seedlings, were observed last year, but none were encountered this year. Several individual plants of $A$. canescens are still present on the site although not encountered this year. This species is not a preferred species on the closure cover because of its deep rooting system.

The density of annual plants was equally low and not different from the density of annual plants on the unseeded area. The most abundant annuals were S. tragus and H. glomeratus. Other annual species commonly found in previous years were rarely encountered.

Plant density was lower this year than in the previous 3 years (Table 8-16), however plant cover has increased (Table 8-15) indicating that although the number of plants may decrease those that are established are increasing in size. A. confertifolia is the most dominant species although there are a few areas, primarily along the western edge of the closure cover, where the density of K. lanata, E. nevadensis, and A hymenoides appears higher and A. confertifolia is less dominant. With time these other species may spread over more of the closure cover. The plants on the closure cover continue to show signs of good growth. Plants are flowering and setting seed. Some A. confertifolia plants are dying off, but this was the first year the density of this species has declined (Table 8-16).

The perennial plants found on the closure cover at U3-ax/bl are becoming well established and continue to provide a viable vegetative cover (Figure 8-3). The density of perennial plant species has not changed significantly over the last 4 years and plant cover continues to increase. It is near 20 percent this year, the highest plant cover for this site since revegetation occurred in the fall of 2000 . The low density of grasses is a concern. However, in certain parts of the closure cover grasses appear to be well established. Potentially, with time, more grasses as well as other species of native shrubs, such as G. spinosa or P. desertorum, will establish on the site and provide a more diverse plant community and more similar to native plant communities in the area. 


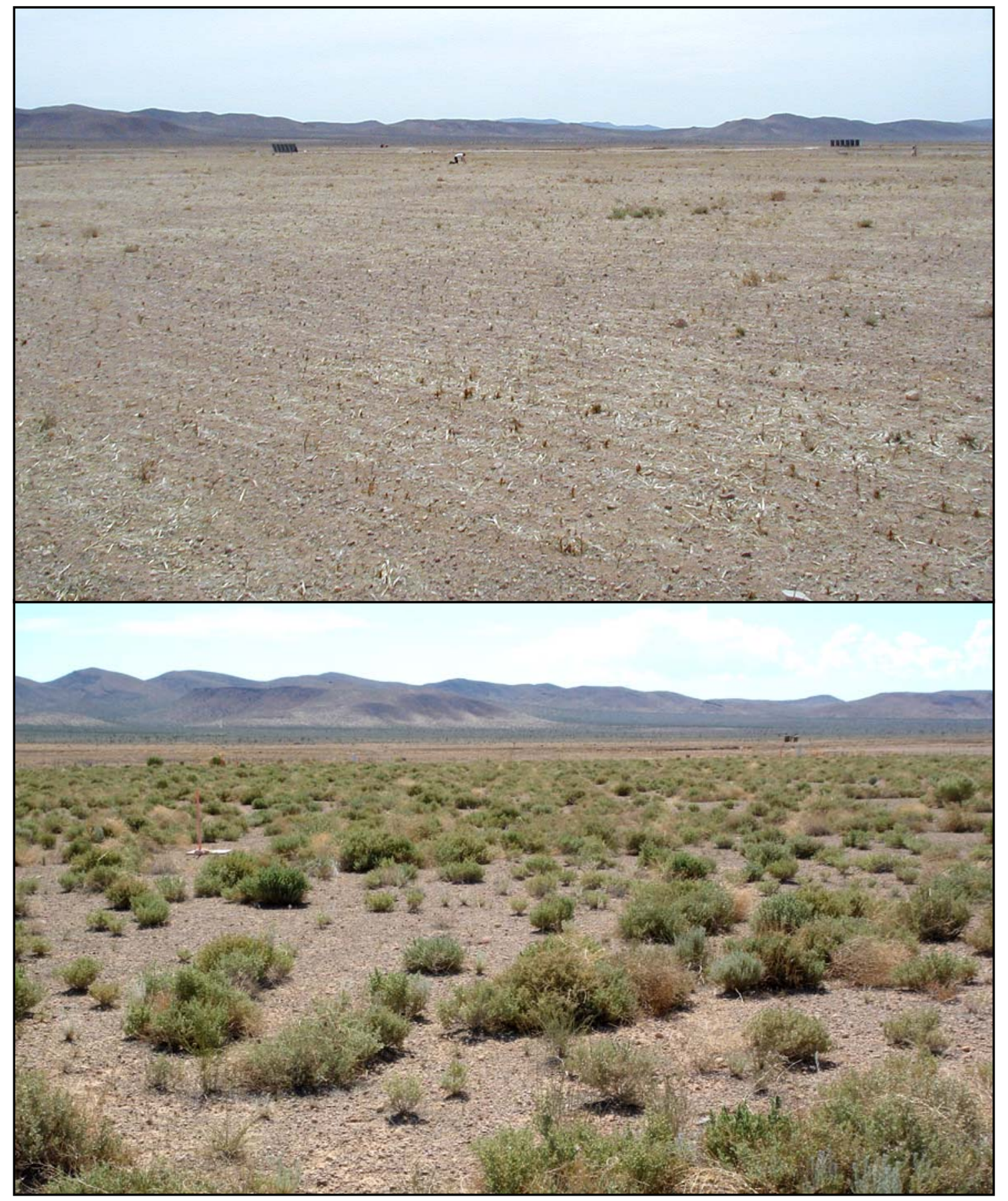

Figure 8-3. CAU 110, U-3ax/bl closure cover cap one year after revegetation in the spring of 2001 (top) and in the spring of 2006 (bottom). (Photographs by D. C. Anderson, May 2001 and May 2006) 


\subsubsection{Wildland Fire Habitat Restoration}

Several major fires on NTS in the past decade have impacted several thousand acres (see Section 4.3). Restoration efforts at these sites have been minimal. The Egg Point Fire in Area 12, that occurred in August 2002, impacted an area near several major facilities and it was important that some action be taken to protect those facilities from the effects of the fire. In the fall of 2002, the burned areas were revegetated using a combination of seeding and transplanting. The site was monitored the first 3 years to evaluate transplant survival and seeding success. The site was not monitored in 2006, but will be in 2007, which will be the fiftth year since it was revegetated. Reseeding trial occurred for two more recent fires, the Shoshone Mountain Fire and Bren Tower Fire; both fires occurred during the summer of 2005. The latter two fire sites were monitored in 2006 and the results are reported in the following sections.

\subsubsection{Shoshone Mountain Fire Trials}

The Shoshone Mountain Fire occurred in Area 14 in June of 2005. The fire burned roughly 830 ha $(2,050 \mathrm{ac})$ in mostly blackbrush habitat with some sagebrush habitat lost at higher elevations. The frequency of fires in blackbrush habitat is the highest of any vegetation type on the NTS yet there has been very little research on how to restore these habitats. A set of reclamation trials was initiated in December of 2005 on areas burned by this fire. The major objective of the trials was to evaluate seeding rates of native species. Several sub-objectives were also evaluated including covering of seed by harrowing, soaking seed prior to seeding, and season of seeding. Five different seeding rates of pure live seed (PLS) [0 seed, 5.60 kilograms per hectare $(\mathrm{kg} / \mathrm{ha})(5$ pounds per acre [lbs/ac] $), 11.20 \mathrm{~kg} / \mathrm{ha}(10 \mathrm{lbs} / \mathrm{ac}), 22.40 \mathrm{~kg} / \mathrm{ha}(20 \mathrm{lbs} / \mathrm{ac})$, and $33.60 \mathrm{~kg} / \mathrm{ha}(30 \mathrm{lbs} / \mathrm{ac})]$ were tested. A total of ten different treatments were tested at this site (Table 8-17). Each treatment was replicated three times in a randomized block design creating a total of 30 plots. Each plot was $6 \mathrm{~m}$ wide by $61 \mathrm{~m}$ long ( $20 \mathrm{ft} \times 200 \mathrm{ft}$ ). Plots were seeded on December 21, 2005, with a mixture of 10 native species that were common to the surrounding area prior to the burn. The seeded species included A. canescens, C. ramosissima, Encelia virginensis (Virgin River brittlebush), E. nevadensis, E. nauseosa, Hymenoclea salsola (white burrobrush), A. hymenoides, Achnatherum speciosa (desert needlegrass), E. elymoides, and S. ambigua.

Plots were sampled in June of 2006. Sampling consisted of stretching a 100-m tape down the center of each plot lengthwise. At 3-m intervals, a $1-\mathrm{m}^{2}$ quadrat was placed and cover and density data were recorded. Twenty quadrats were sampled from each plot. Cover was estimated using an ocular method and reported in Table 8-17. Cover was estimated by life-form, i.e., all shrubs combined, all perennial forbs, all perennial grasses, and all annuals. Estimates of litter and bare ground were also recorded. Density of all seeded species and non-seeded species were recorded within the $1-\mathrm{m}^{2}$ quadrat. Summary data of density are also reported in Table 8-17.

Germination and establishment of seeded species was very poor in 2006 and the density values are very low. The probable reasons for this poor establishment include a rather dry spring and competition with $B$. rubens and $B$. tectorum for the limited moisture. The treatment that had the highest density of seeded species was the spring seeding (March), which also had the lowest densities and cover of invasive brome species. Cover of annual species averaged slightly above 20 percent for all treatments except the spring seeding, which averaged only 15 percent. Cover of all perennials combined averaged less than 2 percent. 
Table 8-17. Results of seeding trials at the Shoshone Mountain Fire burn location.

\begin{tabular}{|c|c|c|c|c|c|c|c|c|c|c|}
\hline & \multicolumn{10}{|c|}{ Treatment Numbers } \\
\hline & 1 & 2 & 3 & 4 & 5 & 6 & 7 & 8 & 9 & 10 \\
\hline $\begin{array}{l}\text { Seeding rate kg/ha } \\
\text { (Ibs/ac) PLS }\end{array}$ & 0 & 0 & $\begin{array}{l}5.6 \\
(5.0)\end{array}$ & $\begin{array}{c}11.2 \\
(10.0)\end{array}$ & $\begin{array}{c}22.4 \\
(20.0)\end{array}$ & $\begin{array}{c}22.4 \\
(20.0)\end{array}$ & $\begin{array}{c}22.4 \\
(20.0)\end{array}$ & $\begin{array}{c}33.6 \\
(30.0)\end{array}$ & $\begin{array}{c}5.6 \\
(5.0)\end{array}$ & $\begin{array}{c}22.4 \\
(20.0)\end{array}$ \\
\hline Harrowed & No & Yes & Yes & Yes & Yes & Yes & Yes & Yes & No & No \\
\hline Soaked seed & No & No & Yes & Yes & Yes & No & Yes & Yes & No & No \\
\hline Season seeded & Fall & Fall & Fall & Fall & Fall & Fall & Spring & Fall & Fall & Fall \\
\hline \multicolumn{11}{|l|}{ Density $\left(\mathrm{m}^{2}\right)$} \\
\hline All seeded species & 0.00 & 0.05 & 0.03 & 0.07 & 0.20 & 0.45 & 2.43 & 0.42 & 0.12 & 0.15 \\
\hline $\begin{array}{l}\text { Bromus species } \\
\text { Cover (\%) }\end{array}$ & 45.42 & 36.18 & 34.67 & 32.20 & 50.95 & 33.75 & 27.27 & 36.32 & 34.95 & 33.87 \\
\hline Shrubs & 1.17 & 0.37 & 1.58 & 0.08 & 1.20 & 0.27 & 1.08 & 0.73 & 0.35 & 1.55 \\
\hline Grasses & 0.00 & 0.00 & 0.00 & 0.00 & 0.00 & 0.00 & 0.00 & 0.00 & 0.00 & 0 \\
\hline Forbs & 0.00 & 0.10 & 0.08 & 0.05 & 0.02 & 0.02 & 0.07 & 0.05 & 0.00 & 0.03 \\
\hline Annuals & 22.25 & 23.52 & 20.88 & 25.07 & 22.53 & 23.17 & 13.77 & 22.08 & 19.23 & 18.93 \\
\hline Litter & 11.22 & 8.60 & 10.68 & 8.58 & 8.50 & 7.85 & 8.87 & 9.42 & 10.12 & 9.12 \\
\hline Bare ground or rock & 65.37 & 67.42 & 66.77 & 66.22 & 67.75 & 68.70 & 76.22 & 67.72 & 70.30 & 70.37 \\
\hline
\end{tabular}

\subsubsection{BREN Tower Fire Data}

The BREN Tower fire occurred in Area 25 in June of 2005. The fire burned roughly 397 ha (980 ac) in mostly L. Tridentat - A. durmusa habitat with some blackbrush habitat burned at higher elevations. The frequency of fires in L. Tridentat - A. durmusa habitat is increasing in recent years because of the invasion of annual grasses, particularly B. rubens. There has been very little research on how to restore these habitats, and very few seeding projects have been successful in the past. Because of the need to restore areas that have burned particularly in desert tortoise habitat, a set of reclamation trials was initiated in December of 2005 , on areas burned by this fire. The major objective of the trials was to evaluate seeding rates of native species. Several sub-objectives were also evaluated including covering of seed by harrowing and soaking seed prior to seeding. Five different seeding rates [0 seed, $5.60 \mathrm{~kg} / \mathrm{ha}(5 \mathrm{lbs} / \mathrm{ac}), 11.20 \mathrm{~kg} / \mathrm{ha}(10 \mathrm{lbs} / \mathrm{ac})$, $22.40 \mathrm{~kg} / \mathrm{ha}(20 \mathrm{lbs} / \mathrm{ac})$, and $33.60 \mathrm{~kg} / \mathrm{ha}(30 \mathrm{lbs} / \mathrm{ac})]$ were tested. A total of nine different treatments were tested at this site. Treatments were the same as the Shoshone Mountain trials with the exception of the spring seeding, which was omitted from this site. Each treatment was replicated four times in a randomized block design, creating a total of 36 plots. Each plot was $6 \mathrm{~m}$ wide by $61 \mathrm{~m}$ long $(20 \times 200 \mathrm{ft})$. The plots were seeded on January 5, 2006, with a mix of seven native species common in that area. Seeded species included L. tridentata, A. dumosa, A. canescens, A. confertifolia, E. nevadensis, A. speciosa. and S. ambigua.

The plots were revisited several times during the spring and early summer to assess germination and establishment of the seeded species. However, because of the lack of adequate rainfall, essentially no germination had occurred and a decision was made to not sample the plots in 2006. If adequate rainfall for germination occurs in 2007 , the plots will be sampled. 


\subsection{MONITORING THE NPTEC}

\subsection{Task Description}

Biological monitoring at the NPTEC on the playa of Frenchman Lake in Area 5 is performed, if necessary, for certain types of chemical releases as per the center's programmatic Environmental Assessment. In addition, Environment, Safety, Health, and Quality Division has requested that the NSTec monitor any test which may impact plants or animals downwind off the playa. A Biological Monitoring Plan for the NPTEC was prepared in FY 1996 and updated in FY 2002 (BN, 2002a). It describes how field surveys will be conducted to determine test impacts on plants and animals and to verify that the center's program complies with pertinent state and federal environmental protection legislation. The design of the monitoring plan calls for the establishment of three control transects and three treatment transects at three distances from the main chemical release points on the playa. The control and treatment transects have similar environmental and vegetation characteristics.

NSTec biologists are tasked to review chemical release test plans to determine if field monitoring along the treatment transects is required for each test as per the monitoring plan criteria. All test-specific field monitoring is funded through the NPTEC. Since 1996, the majority of chemical releases being studied at the center have used such small quantities that downwind test-specific monitoring has not been necessary.

\subsection{Task Progress Summary}

NSTec reviewed chemical spill test plans for the following two activities in 2006: Raven and Tarantula II. Chemicals were released at such low volumes or low toxicity that there was no need to monitor downwind transects for biological impacts. The Raven test was conducted at Port Gaston and Tarantula was conducted on Frenchman Playa.

Baseline monitoring was conducted at established control-treatment transects near the NPTEC in May and October. This monitoring noted the condition of plants and the presence of wildlife sign during the period of vegetative growth and following summer drought, respectively. No differences in biota were noted along downwind (treatment) versus upwind (control) transects. There was a difference in the amount of small mammal activity at both the 3- and 5-km transects compared with other years. The additional precipitation and increased vegetation production in 2005 appear to have had a positive impact on small mammal reproduction and activity in 2006. Baseline monitoring data are collected to document cumulative impacts over time of test center activities on biota downwind of the facility. These data are made available to neighboring land managers upon request. 


\section{THIS PAGE IS INTENTIONALLY LEFT BLANK}




\subsection{LITERATURE CITED}

Anderson, D. C. 1998. Distribution of Clokey's Eggvetch (Astragalus oophorus var. clokeyanus) on the Nevada Test Site. DOE/NV/11718 -262, Bechtel Nevada, Las Vegas, NV. December 1998.

Anderson, D. C., and W. K. Ostler. 2002. Revegetation of degraded lands at U.S. Department of Energy and U.S. Department of Defense installations: Strategies and successes. Arid Land Research and Management. 16(3): 197-212.

Atwood, N. D., F. J. Smith, and T. A. Knight. 2002. Two New Species of Phacelia (Hydrophyllaceae) from the Southwestern United States. Novon 12: 18-26.

Banta, B. H. 1962. Notes on the distribution of the western red-tailed skink, Eumeces gilberti rubricaudatus Taylor, in southern Nevada. Herpetologica 18: 129-130.

Barneby, R. C. 1941. A New Species of Cymopterus from Nevada. Leaflets of Western Botany 3:81-83.

Beatley, J. C. 1977a. Endangered Plant Species of the Nevada Test Site, Ash Meadows, and Centralsouthern Nevada. COO-2307-11, U.S. Energy Research and Development Administration, Nevada Test Site, NV.

Beatley, J. C. 1977b. Threatened Plant Species of the Nevada Test Site, Ash Meadows, and Centralsouthern Nevada. COO-2307-12, U.S. Energy Research and Development Administration, Nevada Test Site, NV.

Bechtel Nevada. 1996. Basic Environmental Compliance and Monitoring Program Fiscal Year 1996. Environmental Sciences Division, Las Vegas, NV. September 27, 1996.

Bechtel Nevada. 1997. Ecological Monitoring and Compliance Program Fiscal Year 1997 Report. Las Vegas, NV, September 30, 1997.

Bechtel Nevada. 1998. Ecological Monitoring and Compliance Program Fiscal Year 1998 Report. DOE/NV/11718 - 255, Las Vegas, NV. October 1998.

Bechtel Nevada. 1999. Ecological Monitoring and Compliance Program Fiscal Year 1999 Report. DOE/NV/11718 - 387, Las Vegas, NV. December 1999.

Bechtel Nevada. 2000. Ecological Monitoring and Compliance Program Fiscal Year 2000 Report. DOE/NV/11718 - 484, Las Vegas, NV. September 2000.

Bechtel Nevada. 2001a. Adaptive Management Plan for Sensitive Plant Species on the Nevada Test Site. DOE/NV/11718-507, Las Vegas, NV. March 2001.

Bechtel Nevada. 2001b. Ecological Monitoring and Compliance Program Fiscal Year 2001 Report. DOE/NV/11718 - 645, Las Vegas, NV. December 2001.

Bechtel Nevada. 2002a. Biological Monitoring Plan for Hazardous Materials Spill Center. Bechtel Nevada, Environmental Monitoring, Ecological Services, Las Vegas, NV. March 2002. 
Bechtel Nevada. 2002b. Ecological Monitoring and Compliance Program Fiscal Year 2002 Report. DOE/NV/11718 - 753, Las Vegas, NV. September 2000.

Bechtel Nevada. 2003. Ecological Monitoring and Compliance Program Fiscal Year 2003 Report. DOE/NV/11718 - 850, Las Vegas, NV. December 2003.

Bechtel Nevada. 2005. Ecological Monitoring and Compliance Program Fiscal/Calendar Year 2004 Report. DOE/NV/11718 — 985, Las Vegas, NV. March 2005.

Bechtel Nevada. 2006. Ecological Monitoring and Compliance Program Calendar Year 2005 Report. DOE/NV/11718-1196, Las Vegas, NV. March 2006.

Blomquist, K. W., T.A. Lindemann, G. E. Lyon, D. C. Steen, C. A. Wills, S. A. Flick, and W. K. Ostler. 1995. Current Distribution, Habitat, and Status of Category 2 Candidate Plant Species on and Near the U.S. Department of Energy's Nevada Test Site. EGG11265-1149, EG\&G Energy Measurements, Las Vegas, NV. December 1995.

Blomquist, K. W., C. A. Wills, W. K. Ostler, K. R. Rautenstrauch, and T. P. O'Farrell. 1992. Distribution, Life History, Management, and Current Status of Astragalus beatleyae on the U.S. Department of Energy's Nevada Test Site. EGG10617-2187, EG\&G Energy Measurements, Santa Barbara Operations, Goleta, CA. November 1992.

BN, see Bechtel Nevada.

Boone, J. L., and C. L. Sowell. 1999. Eumeces gilberti rubricaudatus. Herpetological Review 30:52.

Brack, J.W. 1993. The Pahute Green-gentian (Frasera pahutensis) Survey and Status Summary.

U.S. Department of Agriculture, Forest Service, Toiyabe National Forest, Tonopah Ranger District.

Bradley, P. V., M. J. O’Farrell, J. A. Williams, and J. E. Newmark. Editors. 2006. The revised Nevada bat conservation plan. Nevada Bat Working Group. Reno, NV. 216pp.

Civilian Radioactive Waste Management System. Management and Operating Contractor. 1999.

Reclamation Feasibility Studies at Yucca Mountain, Nevada: 1992-1995.

B00000000-01717-5700-00003 REV 00. Prepared for U.S. Department of Energy by TRW Environmental Safety Systems, Inc.

DOE/NV, see U.S. Department of Energy, Nevada Operations Office.

Ellison, L. E., T. J. O’Shea, M .J. Bogan, A. L. Everette, and D. M. Schneider. 2003. Existing data on colonies of bats in the United States: Summary and analysis of the U.S. Geological Survey's bat population database. Pages 127-237. In: Monitoring trends in bat populations of the United States and Territories: problems and prospects. O'Shea, T. J., and M. S. Bogan, editors.

USGS/BRD/ITR—2003-0003, 274 p.

FWS, see U.S. Fish and Wildlife Service.

Greger, P. D., and E. M. Romney. 1999. High Foal Mortality limits Growth of a Desert Feral Horse Population in Nevada. Great Basin Naturalist. 59(4):374-379. 
Giles, K., and J. Cooper. 1985. Characteristics and Migration Patterns of Mule Deer on the Nevada Test Site. EPA 600/4-85-030.

Hall, D. B. 2000. Bat monitoring on the Nevada Test Site in south-central Nevada. Transactions of the Western Section of the Wildlife Society 36:8-14.

Hall, D. B.. and D. C. Anderson. 1999. Reclaiming Disturbed Land Using Supplemental Irrigation in the Great Basin/Mojave Desert Transition Region after Contaminated Soils Remediation: the Double Tracks Project. In: McArthur, E. D., W. K. Ostler, and C. L. Wambolt, comps. 1999. Proceedings: shrubland ecotones; 1998 August 12-14; Ephraim, UT. Proc. RMRS-P-11. Ogden, UT: U.S. Department of Agriculture, Forest Service, Rocky Mountain Research Station.

Hall, D. B., P. D. Greger, A. V. Cushman, and C. A. Wills. 2003. Ecology of the Western Burrowing Owl on the Nevada Test Site. DOE/NV/11718-701. Bechtel Nevada, Ecological Services, Las Vegas, NV. December 2003.

Hall, D. B. personal communication with R. Sherwin, April 2006.

Hall, D. B. personal communication with M.J. O’Farrell, August 2006.

Hall, D. B. personal communication with P.M. Conrad, December 2006.

Hansen, D. J., P. D. Greger, and C. A. Wills. 1997. Nevada Test Site Wetlands Assessment. DOE/NV/11718-124, Bechtel Nevada, Ecological Services, Las Vegas, NV. May 1997.

Hansen, D. J., and W. K. Ostler. 2002. Vegetation Change Analyses User's Manual. DOE/NV/11718—729, Bechtel Nevada, Ecological Services, Las Vegas, NV. October 1, 2002.

Hansen, D. J., and W. K. Ostler. 2003. Rooting Characteristics of Vegetation Near Areas 3 and 5 Radioactive Waste Management Sites at the Nevada Test Site. DOE/NV/11718 - 595, Bechtel Nevada, Ecological Services, Las Vegas, NV. September 30, 2003.

Hansen, D. J., and W. K. Ostler. 2004. A Survey of Vegetation and Wildland Fire Hazards on the Nevada Test Site. DOE/NV/11718-981. Bechtel Nevada, Ecological Services, Las Vegas, NV. September 2004.

Hansen, D. J. personal communication with J.A. Brown, October 2006.

Hardy, R. 1948. The greater western skink in Nevada and Utah. Herpetologica 4:165.

Hickman, J. C. 1993. The Jepson Manual; Higher Plants of California. University of California Press, Berkeley, CA.

Hunter, R. B. 1994. Status of the Flora and Fauna on the Nevada Test Site, 1992. DOE/NV/11432-58. Reynolds Electrical \& Engineering Co., Inc., Las Vegas, Nevada.

Hunter, R. B., E. M. Romney, and A. Wallace. 1980. Fencing enhances shrub survival and growth for Mojave Desert revegetation. Great Basin Naturalist Memoirs No. 4:212-215. 
Hunter, R. B., E. M. Romney, and A. Wallace. 1987. Revegetation on disturbed desert land at NUWAX and SEDAN. In: The Dynamics of Transuranics and Other Radionuclides in Natural Environments. Howard, W. A., and R. G. Fuller (Eds.). U.S. Department of Energy, Nevada Operations Office, Las Vegas, NV. NVO-272, pp. 79-97.

Medica, P. A., O. L. Haworth, and M. S. Kelly. 1990. Eumeces gilberti rubricaudatus. Herpetological Review 21:40.

Morefield, J. 1992. Frasera pahutensis Reveal, Interim Status Report. Prepared for U.S. Department of Agriculture, Forest Service, Toiyabe National Forest, Tonopah Ranger District.

Morrison, M. L., and L. S. Hall. 1999. Habitat relationships of amphibians and reptiles in the Inyo-White Mountains, California and Nevada. Pages 233-237. In: Proceedings: ecology and management of pinyon-juniper communities within the Interior West. Monsen, S. B., and R. Stevens, compilers. USDA Forest Service Proceedings RMRS-P-9.

Mozingo, H. N., and M. J. Williams. 1980. Threatened and Endangered Plants of Nevada: an Illustrated Manual. Department of Interior, U.S. Fish and Wildlife Service and Bureau of Land Management, Reno, NV.

National Interagency Fire Center, 2006. National Wildland Fire Outlook, June 1 to June 30, 2006. Accessed on June 1, 2006 at: http://www.nifc.gov/nicc/predictive/outlooks/g_seasonal-outlook.pdf. Intelligence-Predictive Services Section at the National Interagency Coordination Center, Boise, ID.

National Oceanic and Atmospheric Administration, 2006. Extended weather forecast for June, July, and August of 2006 for temperature and precipitation. Long-range forecast accessed on May 18, 2006 at: http://www.cpc.ncep.noaa.gov/products/predictions/multi_season/13 seasonal outlooks/color/churchill.html. NOAA, National Weather Service, National Center for Environmental Prediction Climate Prediction Center, Camp Springs, MD

National Oceanic and Atmospheric Administration/Air Resources Laboratory, Special Operations and Research Division, 2006. Nevada Test Site (NTS) Climatological Rain Gauge Network. Accessed on May 22, 2006 at: http://www.sord.nv.doe.gov/home climate rain.htm. North Las Vegas, NV.

Nevada Rare Plant Workshop, 2006. Meeting notes of 2000-2006. Accessed on December 1, 2006 at: http://heritage.nv.gov/workshop.htm. Rare Plant Committee of the Nevada Native Plant Society, Carson City-Reno/Las Vegas, NV.

Nevada Administrative Code 503. Hunting, Fishing and Trapping; Miscellaneous Protective Measures

O'Farrell, T. P., and M. L. Sauls. 1985. Small mammals inhabiting Nuclear-Event Sites: Population characteristics and radionuclide body burden. In: The Dynamics of Transuranics and other radionuclides in natural environments. NVO-172.

Ostler, W. K., D. C. Anderson, D. B. Hall, and D. J. Hansen. 2002. New Technologies to Reclaim Arid Lands User's Manual. DOE/NV/11718 - 731, Bechtel Nevada Ecological Services, Las Vegas, NV. October 1, 2001.

Ostler, W. K., D. J. Hansen, D.C. Anderson, and D. B. Hall. 2000. Classification of Vegetation on the Nevada Test Site. DOE/NV/11718--477, Bechtel Nevada Ecological Services, Las Vegas, NV, December 6, 2000. 
Peterson, F. F. 1981. Landforms of the Basin \& Range Province Defined for Soil Survey. Technical Bulletin 28, Nevada Agricultural Experiment Station, University of Nevada Reno. January 1981.

Pierson, E. D., M. C. Wackenhut, J. S. Altenbach, P. Bradley, P. Call, D. L. Genter, C. E. Harris, B. L. Keller, B. Lengus, L. Lewis, B. Luce, K. W. Navo, J. M. Perkins, S. Smith, and L. Welch. 1999. Species conservation assessment and strategy for Townsend's big-eared bat (Corynorhinus townsendii townsendii and Corynorhinus townsendii pallescens). Idaho Conservation Effort, Idaho Department of Fish and Game, Boise, ID.

Priest, K. personal communication with V. Raman, November 13, 2006.

Reveal, J. L. 1971. A New Frasera from Southern Nevada (Gentianaceae). Bulletin of the Torrey Botanical Club 98:107-108.

Rhoads, W. A., and M. P. Williams. 1977. Status of Endangered and Threatened Plant Species on the Nevada Test Site - A Survey. Part 1: Endangered species. EG\&G/EM Santa Barbara, Report No. 1183-2356.

Rhoads, W. A., S. Cochrane, and M. P. Williams. 1978. Status of Endangered and Threatened Plant Species on Nevada Test Site - A Survey. Part 2: Threatened Species. EG\&G/EM Santa Barbara, Report No. 1183-2356.

Rhoads, W. A., S. Cochrane, and M. P. Williams. 1979. Addendum to Status of Endangered and Threatened Plant Species on Nevada Test Site - a Survey. Parts 1 and 2. EG\&G/EM Santa Barbara, Report No. 1183-2356.

Rodgers, T. L., and H.S. Fitch. 1947. Variation in the skinks (Reptilia:Lacertilia) of the skiltonianus group. University of California Publications in Zoology 48:169-220.

Romney, E. M., A. Wallace, and R. B. Hunter, 1989. Transplanting of native shrubs on disturbed land in the Mojave Desert, pp. 50-53. In: Proceedings of the Symposium on Shrub Ecophysiology and Biotechnology; 1987 June 30 - July 2: Logan, UT. Wallace, A., E. D. McArther, and M. R. Haferkamp (Compilers). General Technical Report INT-256, U.S. Department of Agriculture, Forest Service, Intermountain Research Station, Ogden, UT.

Shabbara, H. M. 1999. Three new records of Funariaceae from Egypt. Journal of Bryology 21: 201-205.

Sherwin, R. E., W. L. Gannon, and J. S. Altenbach. 2003. Managing complex systems simply: understanding inherent variation in the use of roosts by Townsend's big-eared bat. Wildlife Society Bulletin 31:62-72.

Sherwin, R. E., W. L. Gannon, J. S. Altenbach, and D. Stricklan. 2000. Roost fidelity of Townsend's big-eared bat in Utah and Nevada. Transactions of the Western Section of the Wildlife Society $36: 15-20$.

Stark, L. R., A. T. Whittemore, and B. D. Mishler. 2002. Noteworthy bryophyte records from the Mojave Desert. Madroño 49: 49-53. 
Stark, L. R. 2001. Mosses of Nevada On-line, Rare Bryophytes of Conservation Concern in Southern Nevada. Referenced January 24, 2007 at http://heritage.nv.gov/mosses/raremoss.htm.

Stebbins, R. C. 2003. A field guide to western reptiles and amphibians, $3^{\text {rd }}$ edition. Houghton Mifflin Company, New York, 533 pages.

Steen, D. C., D. B. Hall, P. D. Greger, and C. A. Wills. 1997. Distribution of the Chuckwalla, Western Burrowing Owl, and Six Bat Species on the Nevada Test Site. DOE/NV/11718 - 149, Bechtel Nevada Ecological Services, Las Vegas, NV. May 1, 1997.

Turner, J. W., Jr., M. L. Wolfe, and J. F. Kirkpatrick. 1991. Seasonal Mountain lion predation on a free roaming feral horse population. Canadian Journal of Zoology.70:929-933.

Tuttle, M. D., and D. A. R. Taylor. 1998. Bats and Mines. Resource Publication No. 3, Revised Edition. Bat Conservation International, Inc., Austin, TX.

USDA, see U.S. Department of Agriculture.

U.S. Department of Agriculture, Natural Resource Conservation Service. 2006. PLANTS Database, National Plant Data Center. Referenced January 24, 2007 at http://plants.usda.gov/.

U.S. Department of Energy, Nevada Operations Office. 1996. Final Environmental Impact Statement for the Nevada Test Site and Off-Site Locations in the State of Nevada. Volume 1, Chapters 1-9. DOE/EIS 0243, Las Vegas, NV. August 1996.

U.S. Department of Energy, Nevada Operations Office. 1998. Nevada Test Site Resource Management Plan, DOE/NV-518, Las Vegas, NV. December 1998.

U.S. Department of Energy, Nevada Operations Office. 1999. Nevada Test Site Resource Management Plan, Annual Summary, DOE/NV-604, Las Vegas, NV. January 2000.

U.S. Fish and Wildlife Service. 1996. Final Programmatic Biological Opinion for Nevada Test Site Activities. File No. 1-5-96-F-33, August 22, 1996. Reno, NV.

Wallace, A., and E. M. Romney. 1977. Initial land reclamation procedures related to possible Pu-cleanup activities at the Tonopah Test Range. In: Environmental Plutonium on the Nevada Test Site and Environs. White, M. G., P. B. Dunaway, and W. A. Howard (Eds.). NVO-171, Nevada Applied Ecology Group, U.S. Energy Research \& Development Administration, Las Vegas, NV, pp. 65-77.

Wallace, A., and E. M. Romney. 1980. The role of pioneer species in revegetation of disturbed desert areas. Great Basin Naturalist Memoirs 4:31-33.

Wallace, A., E. M. Romney, and R. B. Hunter. 1980. The challenge of a desert: revegetation of disturbed desert lands. Great Basin Naturalist Memoirs 4:216-225.

Webb, R. H., M. B. Murov, T. C. Esque, D. E. Boyer, L. A. DeFalco, D. F. Haines, D. Oldershaw, S. J. Scoles, K. A. Thomas, J. B. Blainey, and P. A. Medica. 2003. Perennial Vegetation Data from Permanent Plots on the Nevada Test Site, Nye County, Nevada. Open-File Report 03-336, U.S. Geological Survey, Tuscon, AZ. 
Wills, C. A., and W. K. Ostler. 2001. Ecology of the Nevada Test Site: An Annotated Bibliography, with Narrative Summary, Keyword Index, and Species Lists. DOE/NV/11718 - 594, Bechtel Nevada, Ecological Services, Las Vegas, NV. September 2001.

Winkel, V. K. 1993. The Reclamation Program of the Treatability Studies for Soil Media Project (TSSM). Poster presented at 8th Wildland Shrub and Arid Land Restoration Symposium, Nevada Test Site Field Tour. CONF-9310276-8, EGG 11265-2027, EG\&G Energy Measurements, Environmental Sciences Department, Las Vegas, NV.

Winkel, V. K. 1995. Effects of Seed Origin and Irrigation on Survival and Growth of Transplanted Shrubs. Poster Presentation at 12th Annual Meeting of the American Society for Surface Mining and Reclamation, Gillette, WY, June 5-8, 1995. EG\&G Energy Measurements.

Winkel, V. K., W. K. Ostler, W. D. Gabbert, and G. E. Lyon. 1994. Effects of seedbed preparation, irrigation, and water harvesting on seedling emergence at the Nevada Test Site. Proceedings: 8th Wildland Shrub and Arid Land Restoration Symposium. CONF-9310276-6, EGG 11265-1062, EG\&G Energy Measurements, Environmental Sciences Department. Las Vegas, NV.

Woodward, R., K. R. Rautenstrauch, D. B. Hall, and W. K. Ostler 1998. The Relative Abundance of Desert Tortoises on the Nevada Test Site within Ecological Landform Units. DOE/NV/11718 - 245, Bechtel Nevada, Ecological Services, Las Vegas, NV. September 1998. 
THIS PAGE INTENTIONALLY LEFT BLANK 


\section{DISTRIBUTION}

U.S. Department of Energy

National Nuclear Security Administration

Nevada Site Office

Technical Library

P.O. Box 98518, M/S 505

Las Vegas, NV 89193-8518

U.S. Department of Energy

National Nuclear Security Administration

Nevada Site Office

Public Reading Facility

c/o Nuclear Testing Archive

P.O. Box 98521, M/S 400

Las Vegas, NV 89193-8521

U.S. Department of Energy

Office of Scientific and Technical Information

P.O. Box 62

Oak Ridge, TN 37831-0062
1 CD (uncontrolled)

1 CD (uncontrolled) 